\title{
Saberes e Experiências de Práticas Pedagógicas no Contexto Educacional
}

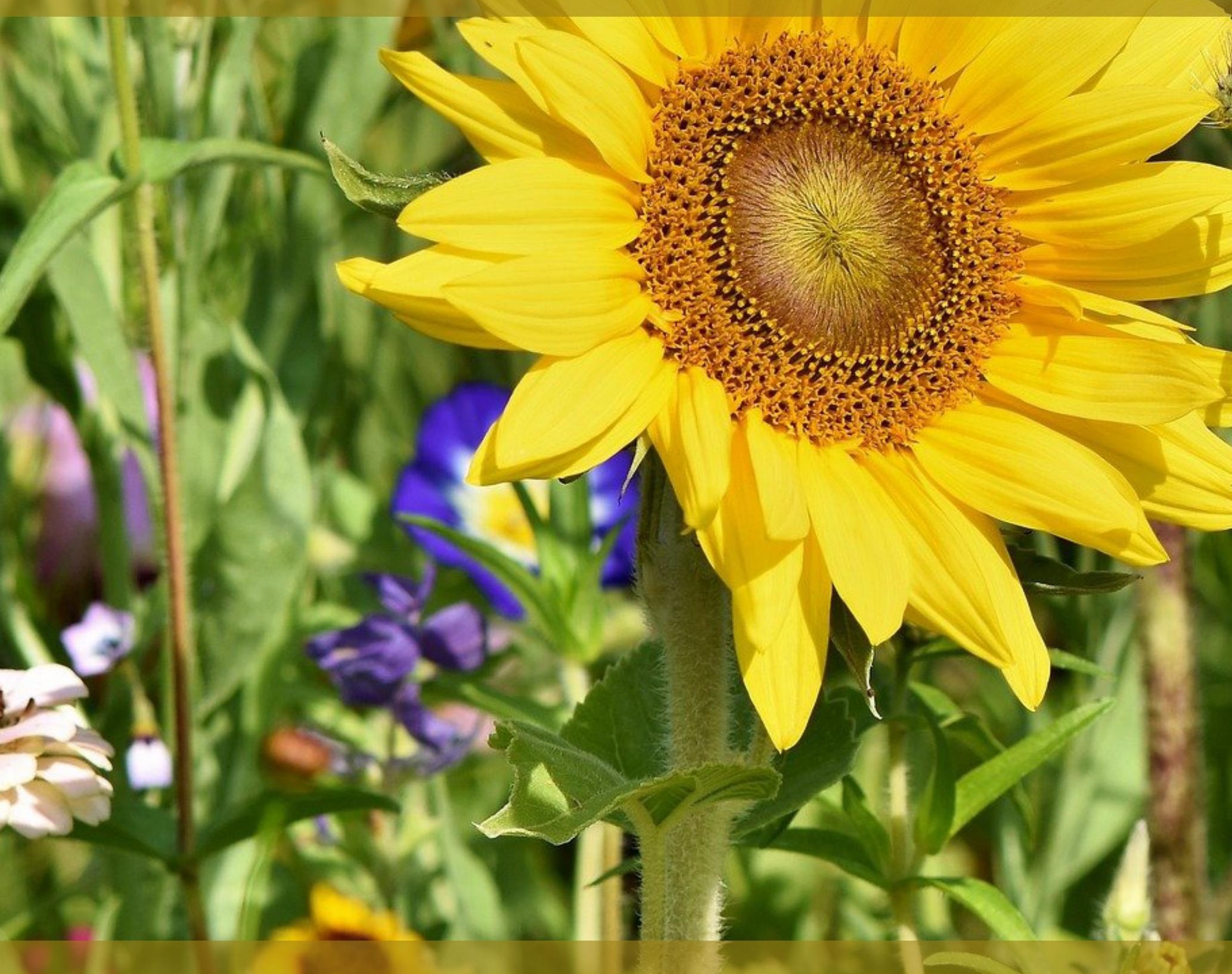

Fabiano Custódio de Oliveira Denise Xavier Torres

Maria da Conceição Gomes de Miranda

[Organizadores]

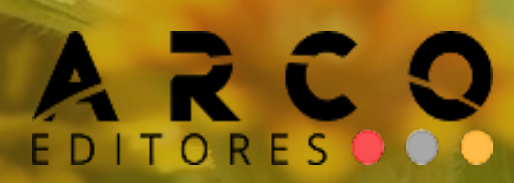




\section{Saberes e Experiências de Práticas Pedagógicas no Contexto Educacional}

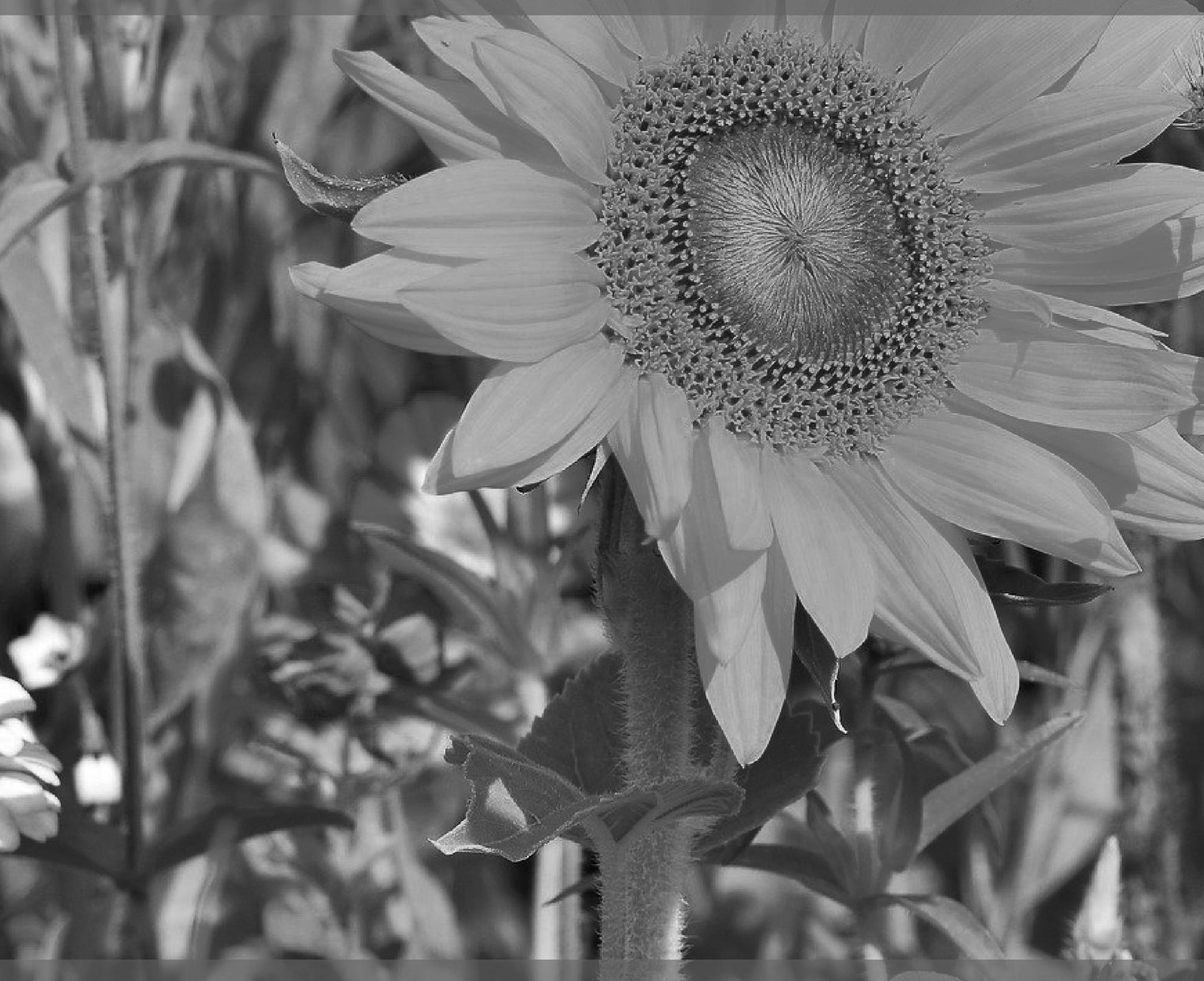

Fabiano Custódio de Oliveira

Denise Xavier Torres

Maria da Conceição Gomes de Miranda

[Organizadores]

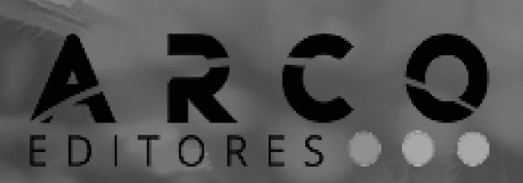




\section{CONSELHO EDITORIAL}

Prof. Dr. Adilson Tadeu Basquerot e Silva

UNIDAVI/SC

http://lattes.cnpq.br/8318350738705473

Profa. Msc. Jesica Wendy Beltrán UFCE- Colômbia

http://lattes.cnpq.br/0048679279914457

Profa. Dra Fabiane dos Santos Ramos UFSM- Santa Maria/RS

http://lattes.cnpq.br/0003382878348789

Dr. João Riél Manuel Nunes Vieira de Oliveira Brito

UAL - Lisboa- Portugal.

http://lattes.cnpq.br/1347367542944960

Profa. Dra. Alessandra Regina Müller Germani

UFFS- Passo Fundo/RS

http://lattes.cnpq.br/7956662371295912

Prof. Dr. Everton Bandeira Martins UFFS - Chapecó/SC

http://lattes.cnpq.br/9818548065077031

Prof. Dr. Erick Kader Callegaro Corrêa UFN- Santa Maria/RS

http://lattes.cnpq.br/2363988112549627

Prof. Dr. Pedro Henrique Witchs

UFES - Vitória/ES

http://lattes.cnpq.br/3913436849859138

Prof. Dr.Thiago Ribeiro Rafagnin UFOB

http://lattes.cnpq.br/3377502960363268
Prof. Dr. Mateus Henrique Köhler

UFSM- Santa Maria/RS

http://lattes.cnpq.br/5754140057757003

Profa. Dra. Liziany Müller Medeiros

UFSM- Santa Maria/RS

http://lattes.cnpq.br/1486004582806497

Prof. Dr. Camilo Darsie de Souza

UNISC- Santa Cruz do Sul/RS

http://lattes.cnpq.br/4407126331414

Prof. Dr. Dioni Paulo Pastorio

UFRGS - Porto Alegre/RS

http://lattes.cnpq.br/7823646075456872

Prof. Dr. Leonardo Bigolin Jantsch

UFSM- Palmeira das Missões/RS

http://lattes.cnpq.br/0639803965762459

Prof. Dr. Leandro Antônio dos Santos

UFU- Uberlândia/MG

http://lattes.cnpq.br/4649031713685124

Dr. Rafael Nogueira Furtado

UFJF- Juiz de Fora/MG

http://lattes.cnpq.br/9761786872182217

Profa. Dra. Angelita Zimmermann

UFSM- Santa Maria/RS

http://lattes.cnpq.br/7548796037921237

Profa. Dra. Francielle Benini Agne

Tybusch

UFN - Santa Maria/RS

http://lattes.cnpq.br/4400702817251869

Copyright (c) Arco Editora, alguns direitos reservados.

Copyright do texto (C) 2021 os autores e as autoras.

Copyright da edição ( 2021 Arco Editora. 
Diagramação e Projeto Gráfico : Gabriel Eldereti Machado imagem capa: $w w w$. freepik.com

Revisão: dos/as autores/as.

Dados Internacionais de Catalogação na Publicação (CIP) (Câmara Brasileira do Livro, SP, Brasil)

Educação do campo [livro eletrônico] : saberes e experiências de práticas pedagógicas no contexto educacional / Fabiano Custódio de 0liveira, Maria da Conceição Gomes de Miranda, Denise Xavier Torres [organizadores]. -- Santa Maria, RS : Arco Editores, 2021. PDF

\section{ISBN $978-65-89949-35-0$}

1. Educação 2. Educação - Finalidades e objetivos 3. Educação rural 4. Escolas do campo 5. Pedagogia 6. Professores - Formação 7. Prática pedagógica I. Oliveira, Fabiano Custódio de. II. Miranda, Maria da Conceição Gomes de. III. Torres, Denise Xavier.

Índices para catálogo sistemático:

1. Educação do campo 370.91734

Maria Alice Ferreira - Bibliotecária - CRB-8/7964

\subsection{9/978-65-CAMPO-35-0}

O padrão linguístico-gramatical, bem como o sistema de citações e referências bibliográficas são prerrogativas de cada autor. Da mesma maneira, o conteúdo e teor de cada capítulo é de inteira e exclusiva responsabilidade de seu respectivo autor. 


\section{EPÍGRAFE}

Não há ensino sem pesquisa e pesquisa sem ensino. Esses que fazeres se encontram um no corpo do outro. Enquanto ensino continuo buscando, reprocurando. Ensino porque busco, porque indaguei, porque indago e me indago. Pesquiso para constatar, constatando, intervenho, intervindo educo e me educo. Pesquiso para conhecer o que ainda não conheço e comunicar ou anunciar a novidade.

Paulo Freire. 


\section{À GUISA DE APRESENTAÇÃO}

Eu acho que uma das tarefas fundamentais de uma educação que seja política em favor das classes trabalhadoras, é exatamente a de possibilitar o exercício no ato de conhecer o mundo, de conhecer o real, o concreto da vida social, de desocultar pedaços ocultados do mundo pela ideologia dominante. $E$ a desocultação é exatamente o que eu chamo de pensar certo. Quanto mais a gente pensa certo, mais a gente se instrumenta para desocultar o que é ocultado pela necessidade fundamental que tem a classe dominante de ocultar.

Paulo Freire ${ }^{1}$

Este e-book expressa o fruto de um trabalho coletivo de pesquisadores e pesquisadoras que possuem uma trajetória de estudos, pesquisas e produções, mas também de estudantes que estão iniciando na pesquisa, isso é o que torna este trabalho apaixonante! Deste grupo de estudantes e pesquisadoreslas quero destacar especialmente os que fazem parte do Nupeforp/CDSA (Núcleo de Estudos e Pesquisa em Educação do Campo, formação de professores/as e Prática Pedagógica), grupo vinculado ao diretório do CNPQ. Destaco também, com muito carinho, os colegas pesquisadores/as convidados de outras instituições, que aceitaram o convite, de compartilhar suas produções nesta publicação.

Este fazer-se pesquisador/a, autor/a, sujeito/a implicado/a em escrever a partir do contexto onde vive, trabalha e pensa, ou seja, "entender como necessitamos nos reeducar para fazer do escrever um ato inaugural, não apenas transcrição do que tínhamos em mente, o que já foi pensado ou dito, mas inauguração do próprio pensar"2. Assim, "desocultar" os saberes e práticas da Educação do Campo no Contexto Educacional, tantas vezes invisibilizados ou estereotipados como algo de inferior, precário, atrasado.

O e-book foi estruturado em um conjunto de nove capítulos, que partiu do reconhecimento da diversidade de práticas de Educação do Campo, em diferentes territórios, nesta produção, encontramos: Paraíba, São Paulo, Paraná e

1 Pedagogia do compromisso, América Latina e Educação Popular, Paz e Terra, 2018, S.P.

2 MARQUES, M.O. Escrever é preciso: o princípio da pesquisa. ljuí: Editora UNIJUI, 1997. P. 13 
Bahia. Em comum os autores e autoras, trazem o reconhecimento da importância do olhar interdisciplinar, e a participação ativa dos sujeitos envolvidos nas práticas.

O Capítulo 1, de autoria de Danilo de Souza Farias, Laurenice Gomes Andrade e Tiago José Vasconcelos de Farias, situa o debate sobre a escola nas comunidades rurais a partir da influência do ruralismo pedagógico no anos de 1930, que trazia uma adaptação da escolarização ao processo de modernização conservadora capitalista, pois fortalecia a mentalidade de que a baixa escolaridade da população camponesa eram a causa do atraso no desenvolvimento do país, não fazia nenhuma relação com a estrutura agrária concentradora de terra e de água, como responsável por essa desigualdade e exclusão da escolarização. Essa visão cultural e educacional hegemônica de perceber o campo, a população camponesa e a escola, trouxe marcas profundas que persistem até os dias atuais. A contraposição a esta visão emerge na década de 1990, com um movimento histórico, político e educacional protagonizado pelos movimentos sociais camponeses, que colocaram o debate da Educação como um direito, e propugna pela escola nas comunidades camponesas com um projeto pedagógico específico, ao mesmo tempo, que buscam a construção de uma legislação que reconheça também a Educação do Campo como uma modalidade de ensino, portanto, um dever do Estado assegurar sua oferta nos diferentes níveis da educação brasileira.

O capítulo 2, de autoria de Ivanalda Dantas Nóbrega Di Lorenzo, Cícera Cecília Esmeraldo Alves, Aldo Gonçalves de Oliveira e Patrícia Brito Souza da Nóbrega, nasceu da experiência que articulou a pesquisa a extensão desenvolvida na EEF Renê Alves Ramalho, localizada no Assentamento de Reforma Agrária Nova Vida, numa região intermediária entre Sousa e Cajazeiras - Sertão da Paraíba. A reflexão interdisciplinar e contextualizada no ensino de Geografia aprofundou os estudos sobre a questão agrária, a territorialização da luta pela Educação do Campo e a propriedade e manejo das águas como algo fundamental também para se pensar a formação docente. 
O capítulo 3, de autoria de José Fábio Vieira Gomes e Luciélio Marinho da Costa, nos trouxe os resultados de uma pesquisa realizada na Escola Antônio Sinésio dos Santos, no Município de Pirpirituba, na Paraíba, na qual investigaram sobre a prática docente nas turmas multisseriadas, refletindo sobre como a ausência de formação inicial e continuada específica para atuação nestas turmas, a imposição de um currículo descontextualizado, o reforço ao modelo seriado, tem fortalecido uma visão estereotipada sobre a escola no campo e para justificar o fechamento de escolas nas comunidades camponesas.

O capítulo 4, de Patrícia Gonçalves de Souza, nos desafia a pensar novas formas de organização da escolaridade, ao analisar a implantação do Ciclo de formação Humana-CFH, na Escola Municipal José Pereira Durval, no município de Irecê, na Bahia, busca explicitar a construção deste conceito na política educacional, como forma de romper a lógica do ensino linear, e ao trazer o protagonismo dos sujeitos em seus diferentes ciclos (infância, adolescência, juventude, adulto e velhice), como protagonistas da sua itinerância formativa, da valorização da cultura, da arte e dos saberes camponeses.

O capítulo 5, aborda a centralidade da categoria trabalho em projetos de Educação do Campo, a partir do projeto de ensino-pesquisa-extensão intitulado: Cultura ambiental no território caipira: história e saberes tradicionais das mulheres do noroeste paulista. A partir do olhar da Pedagogia histórico-crítica, analisa uma experiência de Educação de Jovens e Adultos tendo como categoria chave o trabalho das mulheres, portanto, articula uma abordagem entre trabalho, educação e saberes tradicionais, o que possibilita uma reflexão importante para a Educação de Jovens e Adultos neste território camponês.

O capítulo 6, de Alisson Clauber Mendes de Alencar e Denise Xavier Torres, tece uma reflexão a partir do referencial Freireano sobre a relação educativa e formativa estabelecida no Programa Residência Pedagógica, desenvolvida entre a Universidade Federal de Campina Grande e a Escola Municipal José Bonifácio de Andrade, localizada no município de Sumé, no Cariri Paraibano. A aprendizagem construída na relação entre estudantes de graduação, professoreslas da 
Educação Básica e do Ensino Superior com o planejamento do currículo integrado e contextualizado, na atuação docente por área de conhecimento, são os principais elementos da prática docente enfatizada no artigo.

O capítulo 7, de autoria de Antônio Carlos Soares de Mota, Rosicreide Soares Nogueira e Tiago José de Vasconcelos, trazem o resultado de uma pesquisa-ação, realizada na Escola Estadual Maria Balbina Pereira, no Distrito de Santa Luzia, em Serra Branca no Cariri Paraibano, por estudantes da Licenciatura em Educação do Campo. A pesquisa se articulou com um projeto de extensão de produção de recursos didáticos para o ensino de geografia, e teve como objetivo produzir maquetes e experimentar seu uso na sala de aula, especificamente sobre "as bacias hidrográficas do semiárido", produzindo um diálogo entre conhecimentos populares e científicos no uso e manejo das águas.

O capítulo 8, de autoria de José Diones Nunes dos Santos, relata uma experiência envolvendo estudantes do ensino fundamental I, da Escola Municipal Antônio Alves Feitosa, localizada na comunidade rural do Município de Camalaú, no Cariri Paraibano, e que em 2013, foi nucleada, acolhendo estudantes de comunidades rurais. Com o uso de aparelho celular e uma máquina fotográfica filmadora handycam HD Sony, os estudantes que são transportados de ônibus escolar ou Kombi de outras comunidades rurais até a escola, passaram a registrar os caminhos e as paisagens deste percurso até a escola, o que suscitou no grupo de docentes da escola reflexões sobre o currículo da escola, sua relação com a realidade dos estudantes e como sua fala e história de vida são considerados no currículo escolar.

O capítulo 9, de autoria de Veronice Maria Kawalek, Soraia Stabach Ribas Ferrari dos Santos, Eloiza Aparecida Silva Ávila de Matos e Marcos Vinicius Pereira Ribeiro, nos traz o resultado de uma pesquisa do tipo intervenção pedagógica, com a finalidade de melhoria no processo de ensino e de aprendizagem dos conceitos e conteúdos matemáticos articulado com Ciência. Tal intervenção pedagógica realiza-se numa Escola Estadual do Campo no Município de Salto do Lontra, no Paraná, envolvendo estudantes do sétimo e oitavo ano do Ensino 
Fundamental, cujo registro mostra como ocorreu o planejamento e a integração de conteúdos a partir da construção de um relógio do corpo humano, baseado na Medicina chinesa, (cada canteiro corresponde a um órgão do corpo e ao auge do seu funcionamento dentro de um determinado horário) se construiu um canteiro de ervas medicinais, com base em conceitos e conteúdos matemáticos, e na associação de cada canteiro com um órgão do corpo humano.

As experiências coletivas que a presente publicação buscou socializar se coloca no lugar de "desocultar" o muito já feito para se construir uma escola pública comprometida com a vida e os saberes dos Povos Camponeses, todavia, distâncias imensas ainda temos a percorrer no campo da luta política e da mudança pedagógica. Portanto, nosso desejo de uma leitura agradável e proveitosa, vai junto com um convite na voz de Mia Couto: "Agora sabes: teus braços foram feitos para abraçar horizontes"

Maria do Socorro Silva ${ }^{3}$

Sumé, primavera de 2021

3 Doutora em Educação pela UFPE. Professora da Universidade Federal de Campina Grande, na Unidade Acadêmica de Educação do Campo. Membro do NupeforplResabIRede Pecc-MS e Fonec. Email: maria.socorro@professor.ufcg.edu.br. https://orcid.org/0000-00029480-7619 


\section{SUMÁRIO}

\section{CAPÍTULO 1}

EDUCAÇÃO DO CAMPO: UMA MODALIDADE EM CONSTRUÇÃO .14

Danilo de Souza Farias

Laurenice Gomes Andrade

Tiago José Vasconcelos de Farias

doi: 10.48209/978-65-CAMPO-35-1

\section{CAPÍTULO 2}

DA LUTA CAMPONESA À LUTA POR EDUCAÇÃO DO CAMPO NO ASSENTAMENTO NOVA VIDA I, SOUSA, PARAÍBA: CONTRIBUIÇÕES À FORMAÇÃO DOCENTE.

Ivanalda Dantas Nóbrega Di Lorenzo

Cícera Cecília Esmeraldo Alves

Aldo Gonçalves de Oliveira

Patrícia Brito Souza da Nóbrega

doi: 10.48209/978-65-CAMPO-35-2

\section{CAPÍTULO 3}

A PRÁTICA DOCENTE NA MULTISSERIAÇÃO: UM ESTUDO DE CASO EM UMA ESCOLA DO CAMPO

José Fábio Vieira Gomes

Luciélio Marinho da Costa

doi: 10.48209/978-65-CAMPO-35-3

\section{CAPÍTULO 4}

IMPLANTAÇÃO DO CICLO DE FORMAÇÃO HUMANA NA EDUCAÇÃO INFANTIL DA ESCOLA DO CAMPO JOSÉ PEREIRA DURVAL 


\section{CAPÍTULO 5}

A CENTRALIDADE DA CATEgORIA TRABALHO EM PROJETOS DE EDUCAÇÃO DO CAMPO: A EXPERIÊNCIA DO PROJETO CULTURA AMBIENTAL NO TERRITÓRIO CAIPIRA

Fábio Fernandes Villela

doi: 10.48209/978-65-CAMPO-35-5

\section{CAPÍTULO 6}

UM OLHAR SOBRE O FENÔMENO DA GLOBALIZAÇÃO: RELATO DE EXPERIÊNCIA DO PROGRAMA RESIDÊNCIA PEDAGÓGICA NA ESCOLA DO CAMPO EM SUMÉ - PB 112

Alisson Clauber Mendes de Alencar

Denise Xavier Torres

doi: 10.48209/978-65-CAMPO-35-6

\section{CAPÍTULO 7}

PRODUÇÃO E EXPERIMENTAÇÃO DE RECURSO DIDÁTICO NO ENSINO DE GEOGRAFIA FÍSICA PARA AS ESCOLAS DO CAMPO: A REPRESENTAÇÃO DA BACIA HIDROGRÁFICA DO SEMIÁRIDO POR MEIO DE MAQUETES. 126

Antonio Carlos Soares de Mota

Rosicreide Soares Nogueira

Tiago José Vasconcelos de Farias

doi: 10.48209/978-65-CAMPO-35-7

\section{CAPÍTULO 8}

EDUCAÇÃO E FOTOGRAFIA NO CONTEXTO RURAL: CAMINHOS E PAISAGENS

José Diones Nunes dos Santos

doi: 10.48209/978-65-CAMPO-35-8 


\section{CAPÍTULO 9}

RELÓGIO DO CORPO HUMANO: MATEMÁTICA MÃO NA MASSA E CRIATIVA EM UMA ESCOLA DO CAMPO

Veronice Maria Kawalek

Soraia Stabach Ribas Ferrari dos Santos

Eloiza Aparecida Silva Ávila de Matos

Marcos Vinicius Pereira Ribeiro

doi: 10.48209/978-65-CAMPO-35-9

SOBRE OS ORGANIZADORES.

178

SOBRE AS AUTORAS E OS AUTORES. 


\section{do 10.48209/978-65-CAMPO-35-1}

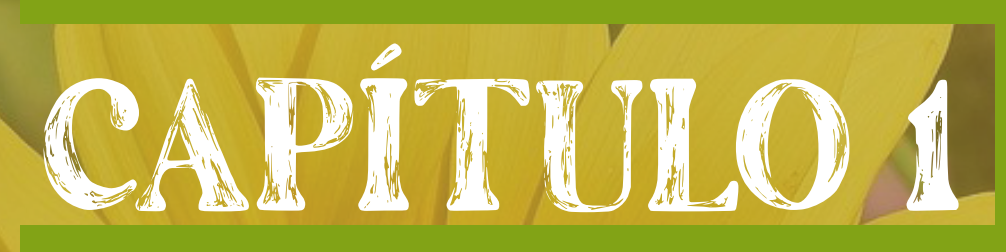

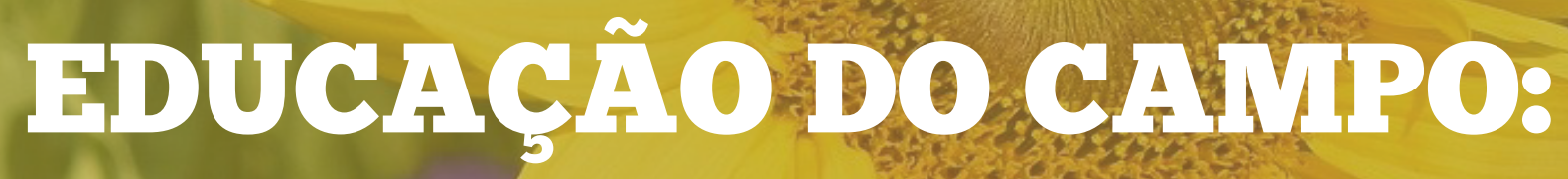 UMA MODAMIDADE PNA}

conshruçẫo

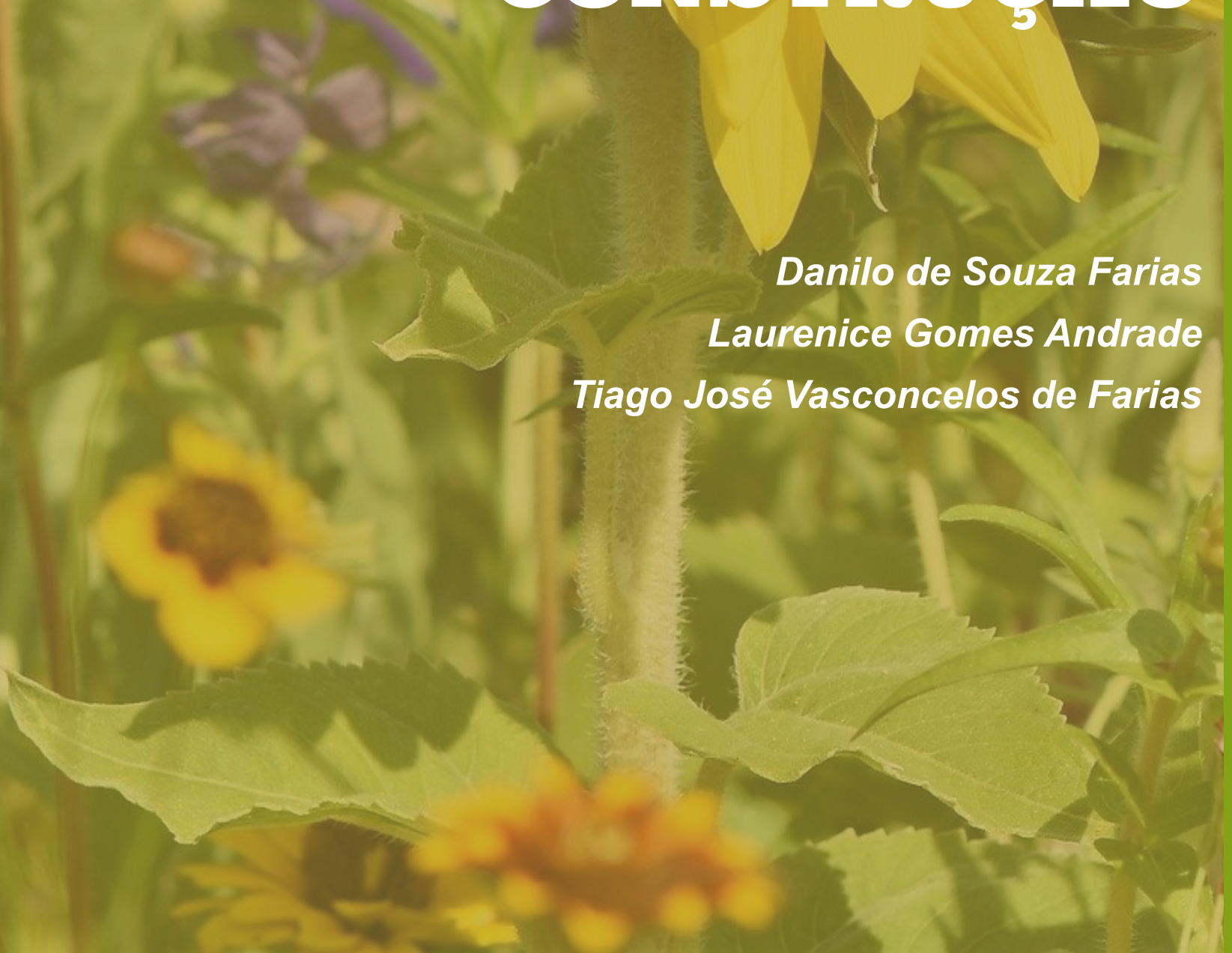


SABERES E EXPERIÊNCIAS DE PRATTICAS PEDAGÓGICAS NO CONTEXTO EDUCACIONAL

\section{INTRODUÇÃ}

O presente texto tem como objetivo central tecer considerações sobre a constituição do Movimento da Educação do Campo, simultaneamente, destacar desafios, estratégias e lutas encampadas por este movimento contra as forças hegemônicas que vêm impossibilitando a construção de um projeto societário compromissado em romper com a divisão de classes sociais.

A metodologia utilizada para a realização deste escrito deu-se a partir de uma revisão de literatura, trouxemos aqui algumas referências que aprofundam a discussão sinalizada, como também, outras que dialogam transversalmente com a temática em questão.

Historicamente, a grande maioria do povo brasileiro ficou desamparada do direito à educação básica, superior, continuada e de qualidade. A adequação dos processos educativos a sistemas de interesses da elite dominante gerou desigualdades sociais incomensuráveis, com impactos negativos às camadas populares, sobretudo aos camponeses, frequentemente vistos e tratados como "jeca tatu", estereótipo usado para inferiorizar e desqualificar estes povos.

Neste contexto, surge um movimento denominado ruralismo pedagógico, fruto de reivindicações quanto a precariedade da educação no campo, que coloca a escola enquanto meio central para implementar o desenvolvimento nos territórios campesinos. Embora este movimento pregasse a necessidade de levar a escola para o campo, nota-se claramente o interesse do referido em integrar ao campesinato a ideia modernizadora defendida pelo capitalismo.

Em contrapartida a este modus operandi, nas últimas duas décadas trabaIhadores do campo, por meio de suas organizações, movimentos e articulações com diversos parceiros, estão imprimindo uma significativa virada conceitual, metodológica e política no que tange à educação. Dessa maneira, puseram em curso um crescente número de experiências pedagógicas alternativas; desencadearam debates e lutas que deram origem a projetos, programas e políticas de 
educação do/no campo, associados a outras políticas necessárias à melhoria das condições de trabalho e de vida no campo.

Feito essa interlocução, pontua-se que este texto se compõe dos seguintes itens: ruralismo Pedagógico: uma concepção hegemônica de educação para escolas rurais; contextualizando o paradigma da Educação do Campo; desafios e perspectivas da Educação do Campo e, por último, apresenta-se as considerações finais.

\section{RURALISMO PEDAGÓGICO: UMA CONCEPÇÃO HEGEMÔNICA DE EDUCAÇÃO PARA ESCOLAS RURAIS}

Ao final da década de 1920 surge no Brasil um movimento denominado "ruralismo pedagógico", que atribui a falta de desenvolvimento do campo e a expansão do êxodo rural à inexistência de escolas rurais, conferindo a estas a responsabilidade de impulsionar o progresso e fixar o homem no meio rural, sem considerar a importância das condições econômicas para a manutenção dos camponeses em suas comunidades. Acrescenta-se aqui que o fator econômico, em última instância, é quem determina as condições de existência de um povo. Neste sentido, Bareiro (2007) destaca que

[...] a escola não é responsável pelo êxodo rural, pois não cabe a ela a incumbência de fixar o homem nesse ou naquele meio. Se as condições econômicas não forem favoráveis à manutenção dos trabalhadores rurais no campo, não há qualidade de escola que garanta sua permanência ou fixação no lugar (BAREIRO, 2007, p. 25).

Diante dessa constatação reafirma-se uma contundente crítica a concepção ruralista, esta defendeu a fixação do homem no campo a partir da ideia de que a escola seria o meio necessário para a mudança de pensamento dos povos campesinos, a fim de provocar nesses inflexões culturais, simultaneamente incorporá-los a um sistema produtivo conduzido pela burguesia agrária e industrial.

Assim, a tarefa da escola seria suprir no educando essa falta de cultura, para que ele pudesse se integrar no processo produtivo do campo. Para os edu- 
SABERES E EXPERIÊNCIAS DE PRÁTICAS PEDAGÓGICAS NO CONTEXTO EDUCACIONAL

cadores que compõem essa corrente, a migração para a cidade tem sempre um caráter negativo. Como a contenção do êxodo era inevitável, a proposta para a escola rural passou a ser a preparação do homem do campo para o exercício de atividades primárias na cidade (BAREIRO, 2007).

Quanto ao modelo de ensino desempenhado no campo destaca-se que este teve como foco central superar o analfabetismo para que o país pudesse desenvolver suas atividades produtivas, aspirando transformar a miséria em riqueza. Vale ressaltar que esse movimento contou com o apoio de parte da elite urbana, objetivando conter o aumento populacional nas cidades e, consequentemente, minimizar os problemas sociais advindos do êxodo rural.

Estudos de Prado (1995) demonstraram que o ruralismo pedagógico consistia na defesa de uma escola adaptada e sempre referida aos interesses e necessidades hegemônicas. Estes encontram-se diluídos entre o que se pôde perceber como interesses de caráter econômico das classes e grupos de capitalistas rurais ou como interesses de grupos, principalmente políticos interessados na questão urbana. Legitimando e reforçando ambas as posturas, encontram-se os intelectuais ligados à educação, estudiosos do papel da educação rural naquele momento e das características e opções que a escola deveria assumir, a fim de compartilhar o projeto abrangente do Estado Nacional.

Esse despontar do Estado Novo impulsionou com bastante acuidade o projeto nacionalista que defendia a integração, a centralização e a hierarquização, fito acatado pelo regime político da época e difundido na sociedade.

Nesse contexto, a escola foi visibilizada enquanto importante instrumento para a difusão das ideias nacionalistas. Foi justamente no espaço escolar que se fomentou a formação de sujeitos patriotas, que por meio do civismo, intensificariam o desenvolvimento do país. Nessa perspectiva, "a escola rural, além de se preocupar com a ação educativa, com o trabalho cívico e a fixação do homem no campo, tinha também a incumbência de divulgar a ideologia oficial que circulava o meio intelectual brasileiro" (SÁ; SILVA, 2014, p. 67). 
SABERES E EXPERIÊNCIAS DE PRÁTICAS PEDAGÓGICAS NO CONTEXTO EDUCACIONAL

Para Miguel Arroyo, um dos maiores problemas apresentados pelo ensino no meio rural constitui-se no fato da escola rural não ter sido pensada para atender as demandas dos povos do campo, não ser evidenciada, quando setores específicos como a agricultura ou a pecuária enfrentam dificuldades "mas quando a cidade e sua economia entram em crise e não conseguem absorver a mão-de-obra ou precisam rebaixar os custos da reprodução de sua força de trabalho, ou quando o poder central precisa se sustentar ou se legitimar em bases rurais" (ARROYO, 1982, p. 2). Assim, ao solucionar-se os problemas da cidade, o campo permanece convivendo com uma série de mazelas sociais, prossegue sendo propriedade do mercado pronto para atender as determinações emanadas pelo sistema capitalismo.

À vista disso, reafirma-se que o fracasso da escola rural no Brasil darse em decorrência dessa ser organizada a partir de um modelo urbanocêntrico, orientado pelo capital industrial, que exigia dessa a formação de mão-de-obra com determinadas especificações capazes de atender as necessidades oriundas da cultura urbano-industrial nacional.

O fato de a indústria implantada no território nacional proibir o ingresso em seus quadros de jovens menores de dezoito anos, analfabetos, teria de alguma forma contribuído para diminuir o analfabetismo nas cidades, à medida que forçava os pais a mandá-los para a escola quando crianças, visando garantir o seu futuro na cidade. Seguindo esse raciocínio, entendia-se que bastaria exigir do roceiro, para ingresso no trabalho, uma certa escolaridade, para que esse fosse obrigado a ingressar na escola, pois o analfabetismo, segundo sua concepção, ocorria em grande medida pela falta de estímulos por parte das autoridades à educação rural (PASTOR apud NETO, 2016).

Mediante essa asserção, torna-se importante destacar que a proibição de menores de idade e analfabetos enquanto trabalhadores das indústrias não foi uma ação consumada pelos proprietários destas, mas pela introdução de legislação específica que coibia iniciativas desta natureza. Outro ponto a ser observado é que o analfabetismo dos jovens figura como sendo ocasionado pela falta de in- 
SABERES E EXPERIÊNCIAS DE PRATTICAS PEDAGÓGICAS NO CONTEXTO EDUCACIONAL

teresse dos pais, embora o real motivo tenha sido a ausência histórica do acesso a serviços educacionais por parte das camadas populares, de maneira especial a população que habitava no campo.

Convém aditar que a inexistência de projetos agrícolas e fundiários direcionados a população campesina foi estratégico para a manutenção da dependência desta, no entanto essa postura incidia na expulsão dos trabalhadores rurais. Conforme destaca Neto (2016)

Se não se discutiam as condições objetivas para a permanência dos trabalhadores no campo pela via das relações de posse e propriedade da terra e, consequentemente, das condições de vida que o trabalhador levava, também não se consideravam os mecanismos de modernização conservadora da expulsão do trabalhador rural (NETO, 2016, p. 41).

Diante desta inferência é necessário acrescentar que os trabalhadores do campo, desprovidos da posse da terra, sujeitos a condições de trabalho extremamente precárias, com destaque para o péssimo assalariamento, viam as cidades como válvula de escape, embora a condição de subalternização os acompanhasse. Nesse sentido, torna-se imprescindível manifestar que as estruturas política, econômica e social do país sempre estiveram a serviço da classe elitista, logo as massas populares, a exemplo dos camponeses foram sendo renegados a própria sorte.

Convém reiterar que o analfabetismo e/ou abandono escolar por parte dos filhos dos trabalhadores rurais quando estes tardiamente tiveram acesso à escola sucedia-se em decorrência das condições econômicas, assim os jovens camponeses desde cedo precisavam trabalhar para ajudar nas necessidades financeiras da família. Desse modo, a não escolarização dos referidos não tinham relação com os aspectos pedagógicos desenvolvidos na escola, mas com as condições materiais as quais se encontravam submetidos. Corroborando com essa discussão, Neto (2016) enfatiza que

Os ruralistas acreditavam que a expulsão do homem do campo muitas vezes se dava pelas condições a que estavam submetidos os estudantes, pois muitos abandonavam a escola ainda muito cedo para ingressar no mercado de trabalho. Alguns sequer chegavam a entrar na escola e a 
SABERES E EXPERIÊNCIAS DE PRATICAS PEDAGÓGICAS NO CONTEXTO EDUCACIONAL

grande maioria cursava somente um pequeno período de tempo, ou seja, enquanto ainda não alcançara a idade considerada ideal para transferir-se para a cidade e começar a produzir para o mercado (NETO, 2016, p. 47).

Essa asserção exibi claramente que a saída do homem do campo não decorria-se exclusivamente por conta do trabalho adversativo realizado na escola, mas pelas precárias condições agrícolas impulsionadas pelo processo de industrialização, pela ocorrência de endemias, altas taxas de mortalidade infantil, dentre uma série de outros problemas que afetavam a sobrevivência dos trabalhadores rurais nos territórios campesinos.

É possível verificar que até o momento pouca coisa mudou no ensino do homem rural, sobretudo porque as propostas de ruralização do ensino, com vistas à fixação do homem do campo surgiram, segundo Jorge Nagle (1974, p. 233-234), no interior de uma corrente nacionalista que apenas parcialmente influenciaram nas reformas das legislações de ensino ocorridas durante a primeira metade do século passado, visto que, para esse autor, "[...]a ruralização do ensino significou, na década dos vinte, a colaboração da escola na tarefa de formar a mentalidade de acordo com as características da ideologia do 'Brasil-país essencialmente-agrícola', o que importava, também, em operar como instrumento de fixação do homem no campo", mas principalmente após os anos cinquenta, nossas políticas econômicas, via de regra, foram voltadas para a industrialização e, consequentemente, para a urbanização do território (NETO, 2016).

Diante do explicitado, ementa-se que a principal disposição do ruralismo pedagógico foi buscar manter o homem no campo, com o apoio massivo da burguesia agrária e industrial, almejando assim conter o êxodo rural. É importante destacar que essa burguesia ampara o ruralismo negando ao povo do campo uma educação unitária, capaz de favorecer uma formação que abarcasse as múltiplas dimensões humanas, ou seja, uma educação integral. Logo, a fragmentação do conhecimento que chegava às escolas rurais era uma estratégia imposta pelo projeto societário da época. Daí a importância de lutar por um projeto de campo, de educação, de sociedade que sobreponha o unitário ao dissociado. 


\section{CONTEXTUALIZANDO O PARADIGMA DA EDUCAÇÃO DO CAMPO}

No campo conceitual podemos afirmar que a Educação do Campo, enquanto uma concepção e prática político-pedagógica, encontra-se em estado de construção, diluída no contexto das contradições históricas da sociedade brasileira, principalmente no que se refere a supervalorização da cidade em detrimento do campo, e o papel da escola nesse processo.

Verifica-se na história da Educação brasileira que até a década de 1990, quando se trata de atender as demandas educacionais direcionadas às populações campesinas, as propostas estão baseadas em ações estatais e pontuais atreladas a interesses de caráter econômico das classes e grupos de capitalistas rurais ou como interesses de grupos, principalmente políticos interessados no desenvolvimento urbano.

Conforme os estudos mostram, o processo de fortalecimento da caminhada da Educação do Campo teve como uma das primeiras referências a luta dos povos indígenas pela educação intercultural, no final da década de 1970, que estimulou o processo de reflexão crítica para que os outros povos do campo começassem a inserir em suas pautas de mobilizações pela democratização do país a luta pelos direitos humanos, dentre estes o direito à educação (SILVA, 2018).

A situação tendeu a se tornar mais favorável no âmbito da educação dos povos do campo com a formulação da constituinte brasileira pela democratização do país e afirmação de uma cultura de direitos que garantiu a conquista pelo direito à educação formal ao final dos anos 1990. Com o movimento histórico que viabilizou o protagonismo da sociedade civil por meio dos movimentos sociais organizados houve a expectativa da democratização da gestão, redução das desigualdades sociais, da participação política da população na conquista de seus direitos, de justiça social e de profissionalização dos educadores(as), expressos na constituição de 1988. 
SABERES E EXPERIÊNCIAS DE PRÁTICAS PEDAGÓGICAS NO CONTEXTO EDUCACIONAL

Em conformidade com a concepção de luta por uma educação para todos, a Lei de Diretrizes e Bases da Educação Nacional (LDBN-Lei $n^{\circ}$ 9.394/96) foi formulada com orientações que garantem o direito a educação para as populações do campo de modo a "adequar" as suas especificidades, como exemplificam os artigos 23, 26 e 28 que tratam sobre a organização escolar e pedagógica. O artigo 28 estabelece as seguintes normas para a educação rural:

Art. 28. Na oferta de educação básica para a população rural, os sistemas de ensino promoverão as adaptações necessárias à sua adequação às peculiaridades da vida rural e de cada região, especialmente:

I - conteúdos curriculares e metodologias apropriadas às reais necessidades e interesses dos alunos da zona rural;

II - organização escolar própria, incluindo adequação do calendário escolar às fases do ciclo agrícola e às condições climáticas;

III - adequação à natureza do trabalho na zona rural (BRASIL,1996).

As reinvindicações e conquistas históricas presentes na constituição de 1988 e na LDBN contribuíram para o acúmulo de forças e para o fortalecimento nos diversos espaços e modos de vida do camponês, principalmente no que se refere ao conceito que permeia tal concepção de educação. Concepção esta que resiste a hegemonia de um sistema educativo excludente, elitista e dominante, interposto pela lógica capitalista. Pelo contrário, a construção teórica/prática da Educação do Campo está embasada na seguinte compreensão expressa no Art. $2^{\circ}$, parágrafo único, das Diretrizes Operacionais para a Educação Básica nas Escolas do Campo (BRASIL, 2020, p.1):

A identidade da escola do campo é definida pela sua vinculação às questões inerentes a sua realidade, ancorando-se na temporalidade e saberes dos estudantes, na memória coletiva que sinaliza futuros, na rede de ciência e tecnologia disponível na sociedade e nos movimentos sociais em defesa de projetos que associem as soluções exigidas por estas questões à qualidade social da vida coletiva do país.

Para Bicalho (2018, p.77), "a defesa de processos formativos que vão além das aptidões e habilidades pode contribuir com aproximação de concepções dia- 
SABERES E EXPERIÊNCIAS DE PRÁTICAS PEDAGÓGICAS NO CONTEXTO EDUCACIONAL

lógicas e humanistas, em que os educandos participam ativamente do seu processo de formação".

Estes sujeitos atuam na busca pela superação da visão tradicional do imaginário social que considera natural que os sujeitos do campo sejam tratados como inferiores e que a situação de miséria seja seu destino. Para tanto, observam, interpretam e agem, conscientemente, na busca de seus direitos fazendo-se protagonistas da sua própria história na perspectiva de transformação social e de emancipação humana. Neste sentido, destaca-se que:

A educação do Campo nasceu das experiências de luta pelo direito e por um projeto político pedagógico vinculados a classe trabalhadora do campo, na sua diversidade de povos indígenas, povos das florestas, comunidades tradicionais e camponesas, quilombolas, agricultores familiares, assentados, acampados à espera de assentamento, extrativistas, pescadores artesanais, ribeirinhos e trabalhadores assalariados rurais. (FÓRUM NACIONAL DE EDUCAÇÃO DO CAMPO, 2012).

As práticas educativas construídas pelos movimentos campesinos, quilombolas e organizações correlatas construíram a concepção de Educação do Campo, interagindo com as outras dimensões da vida do campo. Esse processo aconteceu com a participação de diferentes entidades, dentre as quais podemos destacar: Movimento dos Trabalhadores Sem Terra (MST), da Confederação Nacional dos Trabalhadores(as) Rurais e na Agricultura Familiar (CONTAG), da União Nacional das Escolas Famílias Agrícolas no Brasil (UNEFAB), da Rede de Educação do Semiárido Brasileiro (RESAB), principalmente com a articulação das práticas pedagógicas existentes no campo, possibilitando a construção de uma rede que se movimenta pela luta, pela prática educativa e pela reinvindicação dos direitos (SILVA 2018).

Das ações governamentais impulsionadas por estes movimentos podemos destacar as duas conferências nacionais por uma educação do campo, realizadas em 1998 e 2004, a instituição pelo Conselho Nacional de Educação (CNE), das Diretrizes Operacionais para Educação Básica nas Escolas do Campo, em 2002, as Diretrizes Complementares, em 2008, e o decreto presidencial em 2010. No entanto, Caldart (2007), no III Seminário do PRONERA, destacou que: 
A medida que a Educação do Campo vai se firmando na sociedade, que entra como nome de secretarias ou coordenações de governo, que aparece como especificidades de preceitos legais, que dá nome a cursos e linhas de pesquisas, que indica determinada práticas ou reflexões de movimentos sociais específicos, começa a aparecer uma tendência que desloca a Educação do Campo da sua identidade originária. (III Seminário PRONERA, 2007).

Esta é uma interposição objetiva, aliada aos interesses hegemônicos do campo como lugar de negócio, que pretende promover uma desconfiguração política e pedagógica de fundo da Educação do Campo já que a esta surge como um modelo contra hegemônico de posição política, pedagógica e epistemológica e luta por uma educação que busque contribuir para a sustentação da vida em suas diferentes dimensões, necessidades e formas no campo.

\section{DESAFIOS E PERSPECTIVAS DA EDUCAÇÃO DO CAMPO}

Ao longo de pouco mais de 20 anos da institucionalização da Educação do Campo no Brasil, várias conquistas foram alcançadas perante o Estado, a garantia de políticas específicas asseguraram à classe popular camponesa uma série de direitos que há alguns anos não se imaginava. Contudo, ainda há muito a conquistar. Por isso, a Educação do Campo se caracteriza como um movimento em construção, em busca por uma sociedade mais justa.

Reafirmamos aqui algumas conquistas suscitadas pelo movimento: o reconhecimento da Educação do Campo como uma modalidade de ensino específica para os povos do campo; as diretrizes operacionais que regulamentam o ensino nas escolas campesinas (em todos os níveis); a criação de programas de formação continuada para os(as) professores(as); a criação do curso superior da Licenciatura em Educação do Campo etc. Porém, todas essas conquistas se deram a partir do diálogo com os poderes políticos mediante a reinvindicação dos movimentos populares. E quando isso não acontece, ou acontece de forma incipiente? 
SABERES E EXPERIÊNCIAS DE PRATICAS PEDAGÓGICAS NO CONTEXTO EDUCACIONAL

Os movimentos sociais, as organizações populares têm se munido de pelo menos duas estratégias de resistência para reivindicar direitos: a resistência ativa, e a resistência institucional. A primeira forma de resistência diz respeito às mobilizações de rua, às passeatas, ao enfrentamento direto diante dos poderes públicos, e a segunda refere-se à apropriação jurídica de leis, normativas para garantir a execução dos direitos. Ilse Scherer-Warren tem utilizado um conceito denominado: Rede de Movimento Social, segundo ela:

como resultado de todo esse processo articulatório vai se constituindo o que denominamos, enquanto conceito teórico, de rede de movimento social. Esta pressupõe a identificação de sujeitos coletivos em torno de valores, objetivos ou projetos em comum, os quais definem os atores ou situações sistêmicas antagônicas que devem ser combatidas e transformadas. (SCHERER-WARREN, 2006, p. 113).

Este conceito ajuda a compreender os movimentos sociais como uma rede articulada de movimentos, um movimento de resistência em torno de direitos coletivos perante o poder público, seja redes, fóruns, organizações não-governamentais (ONGs). Nem sempre as formas de organização popular são institucionalizadas.

No contexto político atual, a Educação brasileira, especificamente a Educação do Campo, vem sofrendo ataques permanentes e sistemáticos perante a política neoliberal acentuada pós-golpe decorrido no ano de 2016. Segundo Taffarel (2020, n.p.) "é possível reconhecer o avassalador processo destrutivo implementado pelo governo conservador, de extrema direita, que ascendeu ao Governo em 2019, após um conturbado processo eleitoral ocorrido em 2018.”

Vejamos a seguir algumas palavras aferidas pelo secretário especial de assuntos fundiários, o então Nabhan Garcia, em entrevista à revista VEJA, em 2019, quando perguntado pelas mais de 2 mil escolas mantidas pelo MST: "Não dá para o Brasil admitir em pleno século XXI fabriquinhas de ditadores. Não dá para admitir escolas de marxistas, de leninistas, de bolivarianos, que ensinam crianças a invadir e cometer crimes. Vamos fechar as escolas e punir os respon- 
SABERES E EXPERIÊNCIAS DE PRATICAS PEDAGÓGICAS NO CONTEXTO EDUCACIONAL

sáveis pela doutrinação. Aliás, isso tem de ser qualificado como crime. Crime de lesa-pátria."

Esse discurso explicitamente antidemocrático, esdrúxulo, mencionado pelo representante do Estado, mostra como, atualmente, os movimentos sociais vêm sendo tratados neste país, a criminalização dos movimentos sociais, os discursos de ódio mencionados abertamente pelo presidente da república, reintegrações de posse em plena pandemia, a intensificação dos conflitos territoriais com os fazendeiros, nos coloca diante de um grande desafio.

A Educação do Campo forjou-se a partir do diálogo constante com os movimentos sociais. Logo, todos esses ataques recaem diretamente sobre nós. Daí a necessidade de nos contrapormos estrategicamente e intensamente a esse movimento que insiste em nos ceifar.

Ainda na mesma entrevista o secretário especial compara os Movimentos dos Sem-terra com organizações criminosas, sem o mínimo de compreensão do que realmente este movimento representa. "O MST não tem CNPJ. Onde eles fizeram cursos, em Cuba, na Nicarágua, com as Farc (Forças Armadas Revolucionárias da Colômbia), ensinaram que o correto é ficar na clandestinidade. Você já viu organização criminosa na legitimidade? Será que o PCC (Primeiro Comando da Capital) tem CNPJ? O Comando Vermelho tem CNPJ?".

Um outro aspecto no qual soma-se forças ao conservadorismo, consequentemente interfere diretamente na educação, especificamente na Educação do Campo. Estamos nos referindo aqui ao neoliberalismo. Vejamos a seguir algumas descrições realizadas por Boaventura de Sousa Santos referente ao neoliberalismo:

O neoliberalismo neutralizou, ou enfraqueceu grandemente, os mecanismos democráticos de redistribuição social - ou seja, os direitos socioeconómicos e o Estado providência. Privada do seu potencial redistributivo, a democracia tornou-se completamente compatível com o capitalismo, e em tal grau que ambos se transformaram nos conceitos gémeos que presidem ao novo modelo global das questões políticas e sociais, um modelo imposto a nível mundial pela globalização neoliberal, pelas políticas 
SABERES E EXPERIÊNCIAS DE PRÁTICAS PEDAGÓGICAS NO CONTEXTO EDUCACIONAL

de ajustamento estrutural e, mais recentemente, pela guerra neocolonial. (SANTOS, 2005, p. 19).

A política neoliberal em curso em nosso país é um ataque visível à democracia. Observando um passado não muito longe percebemos o quanto fatos da nossa história acabam se repetindo (continuidades e rupturas) no nosso país. $\mathrm{O}$ autoritarismo, aliado a uma política de reformas envolvendo as áreas sociais de quem mais necessita de investimentos são atingidas frontalmente diante da política neoliberal. Assim, reordenar ou reorganizar a sociedade passa a ser regra em torno da acumulação de capital para a classe rentista.

As reformas implementadas, sobretudo pós golpe (2016), compõem a agenda nacional alinhadas ao interesse internacional visando a acumulação financeira em detrimento dos direitos sociais conquistados a partir de um enfrentamento direto e indireto com o Estado. A emenda à constituição $n^{\circ} 95$ ficou conhecida como "PEC da morte". Essa lei limita investimentos na área da saúde e educação por vinte anos. Em outras palavras, significa dizer: se já falta investimento nessas duas áreas que são primordiais, a tendência é que a procura por serviços básicos aumente à medida em que a população cresce, inviabilizando o acesso da população a serviços essenciais. Sendo assim, Costa 2021 destaca que:

recaindo sobre os pobres como um golpe de misericórdia do neoliberalismo fundamentalista brasileiro, que condena os investimentos em educação, ciência e pesquisa transformando-os em despesas. Que país é capaz de crescer e desenvolver-se sem educação, ciência e pesquisa? Nenhum. O golpe de 2016 é contínuo e segue destruindo diretos e promovendo retrocessos. (COSTA, 2021, p. 337).

A educação pública, especialmente a Educação do Campo, se encontra diante desse complexo contexto político social. Paulo Freire, na obra Pedagogia da Esperança, nos lembra o quanto é importante tê-la para resistir aos ataques à classe trabalhadora, mas é necessário nos mantermos firmes no ato de "esperançar."

Sem um mínimo de esperança não podemos sequer começar o embate, mas, sem o embate até a esperança como necessidade ontológica, se 
SABERES E EXPERIÊNCIAS DE PRÁTICAS PEDAGÓGICAS NO CONTEXTO EDUCACIONAL

desarvora, se desendereça e se torna desesperança que, às vezes, se alonga em trágico desespero. (FREIRE, 1992, p. 6)

Por essa e por outras questões Paulo Freire continua símbolo de resistência nos tempos atuais. Durante a ditadura civil-militar foi alvo de perseguição, remetendo-se ao exílio por suas ideias irem contra a ordem estabelecida. Mas nem por isso deixou de lutar pelo que acreditava: a emancipação de pessoas através da educação. Suas obras continuam sendo inspiração para as bases epistemológicas da Educação do Campo e por isso a Educação do Campo tem como bandeira a 'LUTA'.

\section{CONSIDERAÇÕES FINAIS}

A partir das discussões estabelecidas acima percebemos que a escola é um importante espaço para que seja trabalhada a identidade dos sujeitos do campo, mas nada adianta se as condições econômicas desses sujeitos permanecerem rumadas na precariedade, pois a questão econômica é tão importante quanto as identidades desses povos. Embora o ruralismo pedagógico não tenha sido superado completamente, aos poucos os povos do campo vão se apropriado desses debates, compreendendo as complexidades do campesinato.

Uma outra questão que podemos considerar a partir deste texto é que nem sempre ter uma escola no campo(lugar) significa dizer que esta atue com o conceito epistemológico da Educação do Campo. Em muitos casos, esse conceito é esvaziado e tratado apenas como se estivesse ligado exclusivamente ao espaço do campo. Todavia, reafirma-se aqui que a Educação do Campo tem o compromisso emancipatório de transformar a realidade desses sujeitos, marcados pelas desigualdades sociais, econômicas, entre outros fatores. Se as escolas do campo não tiverem clareza dessa questão corre-se o risco de que tenhamos várias escolas no campo reproduzindo o currículo urbanocêntrico, totalmente distinto de sua realidade.

Assim, é imprescindível ter um currículo diversificado para as diferentes realidades do campo. O Brasil tem dimensões continentais, como podemos ho- 
mogeneizar um padrão curricular para ser aplicado nessas diferentes regiões, em cada localidade? Alguns currículos que aí se apresentam colocam o espaço do campo apenas como um local de produção tão somente agrícola, o que não é verdade. O espaço rural é cheio de determinações, culturas, valores, riquezas naturais e econômicas, com grandes potenciais em diversas áreas, mas também de reprodução social dos sujeitos.

Atualmente vivenciamos um contexto político de ataque aos movimentos sociais, sobretudo à classe trabalhadora, marcado pela forma de governar autoritária e conservadora. Para piorar, um conjunto de reformas econômicas e sociais implementadas nos últimos 5 anos aprofunda esse processo histórico de exploração da classe trabalhadora.

\section{REFERENCIAS}

ARROYO, M. G. Escola, cidadania e participação no campo. Brasília: Em aberto, setembro, 1982.

BAREIRO, E. Políticas Educacionais e Escolas Rurais no Paraná - 1930 2005. (Dissertação de Mestrado). Programa de Pós-graduação em Educação para a Ciência e o Ensino de Matemática, Universidade Estadual de Maringá UEM, 2007.

BICALHO, R. História da educação do campo no Brasil: o protagonismo dos movimentos sociais. In: COELHO, George Leonardo Seabra; ARAÚJO, Gilberto Paulino (Orgs.). Educação do Campo e Cidadania no Brasil Contemporâneo. Palmas/TO: Universidade Federal do Tocantins/EDUFT, 2018.

BRASIL/PR. Lei 9394 de 20/12/1996. Estabelece as diretrizes e bases da educação nacional. Diário Oficial da União. Brasília: Gráfica do Senado,1996.

CALDART, R. Texto de exposição para o III Seminário do Programa Nacional de Educação na Reforma Agrária PRONERA. Luziania-GO, 2007.

CNE/CEB. Resolução n. 01/2002. Institui Diretrizes Operacionais para a Educação Básica nas Escolas do Campo. Brasília, 2002. 
FREIRE, P. Pedagogia da Esperança: um reencontro com a Pedagogia do Oprimido. Paz e Terra, Rio de Janeiro, 1992.

NETO, L. B. Educação rural no Brasil: do ruralismo pedagógico ao movimento por uma educação do campo. Uberlândia: Navegando Publicações, 2016.

PRADO, A. A. Ruralismo Pedagógico no Brasil do Estado Novo. Estudos Sociedade e Agricultura, Rio de Janeiro, n. 4. 1995.

SÁ, E. F.; SILVA, M. O. da. O Ruralismo Pedagógico: uma proposta para organização da escola primária rural. Revista Educação e Cultura Contemporânea, vol. 1, n. 23. 2014.

SANTOS, B. de S. A crítica da governança neoliberal: o Fórum Social Mundial como Política e legalidade cosmopolita subalterna. Revista Crítica de Ciências Sociais, 2005.

SILVA, M. do S. Educação do campo e políticas educacionais: avanços, contradições retrocessos. Revista Educação e Políticas em debate, vol. 7, n.1, 2018. 

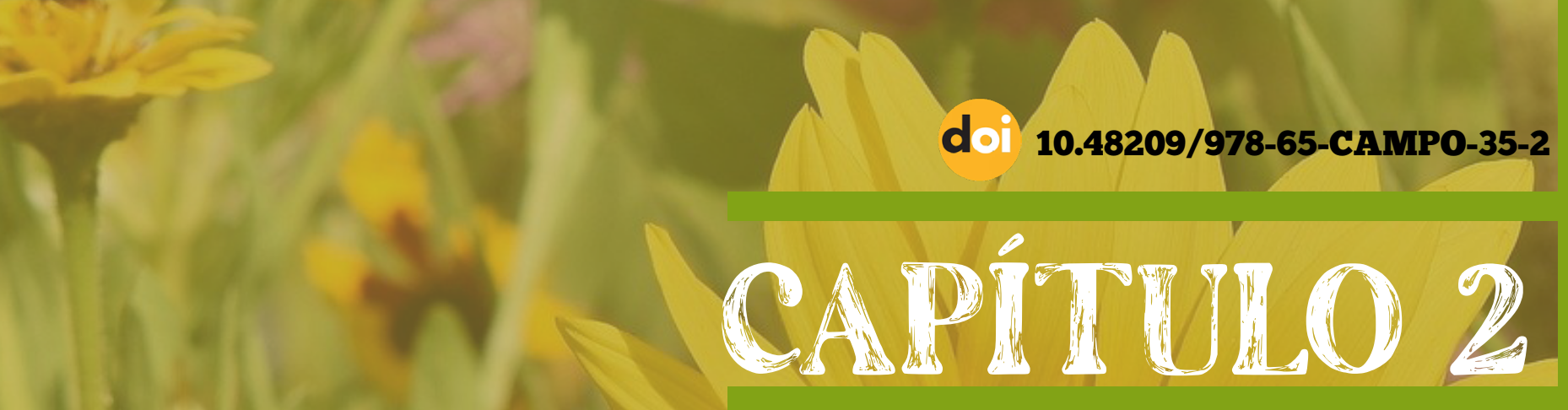

DA TUHA GHIPONDSH A IUHA POR BDUCACHO DO CAMTPO NO ASSIENHAMADH NO NOVA MDA I, SOUSA, PARA IIBA: conHribulgóns A FORMACÃO DOCFHLE

Ivanalda Dantas Nóbrega Di Lorenzo Cícera Cecília Esmeraldo Alves

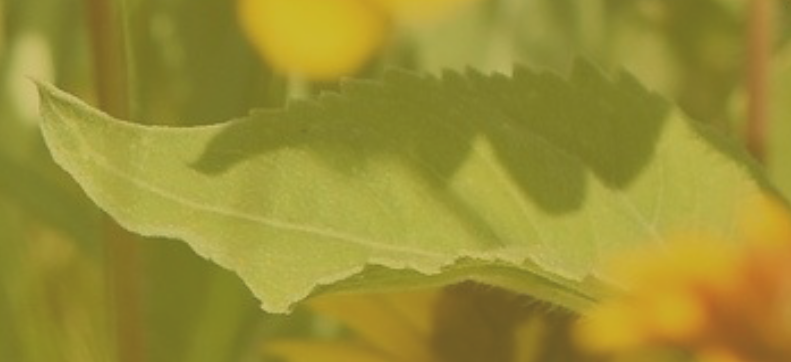

Aldo Gonçalves de Oliveira

Patricia Brito Souza da Nóbrega 


\section{INTRODUÇÃO}

Partilhamos neste escrito de experiências de extensão e pesquisa, enquanto integrantes da Universidade Federal de Campina Grande, Campus Cajazeiras, vivenciadas numa escola do campo no Assentamento Nova Vida I, situado no município de Sousa, Região Intermediária de Sousa-Cajazeiras, Paraíba.

Trata-se da Escola Estadual de Ensino Fundamental (E.E.E.F.) Renê Alves Ramalho (Figura 01), situada no campo, no Assentamento Rural da Reforma Agrária Nova Vida, município de Sousa, Paraíba, Região Intermediária de Sousa-Cajazeiras, fundada no ano de 2019, cuja gestão se dá pelo Movimento dos Trabalhadores e Trabalhadoras Rurais Sem Terra - MST e, o Estado da Paraíba, sendo a representante gestora, um integrante do MST, a qual realiza a cogestão em parceria com o Estado. Seus docentes e servidores são contratados temporários, sendo duas servidoras do Assentamento e quatro servidoras oriundas das cidades de Sousa e Aparecida-PB.

O público direto atendido envolvido nos projetos de pesquisa e extensão são cinco professoras de Educação Básica do Ensino Fundamental; duas integrantes da Secretaria de Estado da Educação; três coordenadores da UFCG; quatro colaboradores; 45 educandos da E.E.E.F. Renê Alves Ramalho; comunitários de três áreas de assentamentos rurais; 03 Professores de Ensino Superior. 02 bolsistas e 06 voluntários (Figura 02). O público indireto é identificado pelas famílias que participam da E.E.E.F. Renê Alves Ramalho, Sousa - PB, oriundas de três áreas de Assentamentos Rurais da Reforma Agrária no Semiárido Paraibano, em áreas do Projeto de Irrigação das Várzeas de Sousa- PIVAS, Paraíba. 
Figura 1 - EEEF Renê Alves Ramalho com duas bandeiras dispostas hasteadas: Bandeira do MST e Bandeira do Brasil.
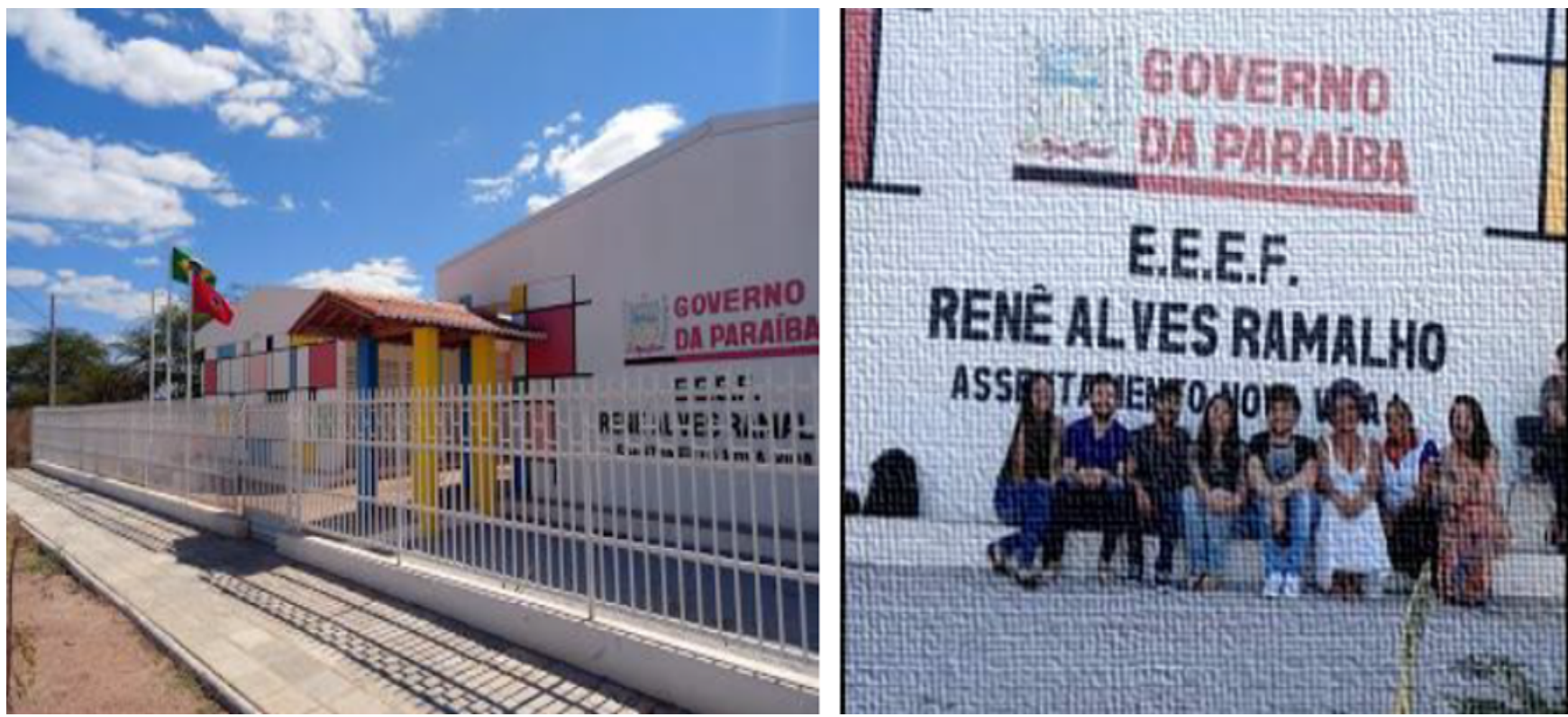

Fonte: Arquivo PROBEX UFCG: 2019.

O projeto de extensão iniciou na referida escola no mês de maio de 2019 , por ocasião do Projeto de Bolsa de Extensão - PROBEX 2019, da UFCG, vigente até dezembro de 2019 , pois intencionávamos conhecer a escola e sua comunidade. O referido projeto evoluiu com perspectiva de pesquisa nesse mesmo ano, tendo a extensão sido renovada no ano de 2021, portanto, há na escola dois projetos de pesquisa e extensão, em andamento.

Tais projetos envolvem temáticas sobre formação inicial e continuada docente, ensino de Geografia seguindo os princípios basilares da Política Nacional da Educação do Campo, campesinato e interdisciplinaridade. Sua realização tem como maiores motivações a reflexão acerca do distanciamento dos Projetos Pedagógicos das escolas em relação à história de vida dos sujeitos educandos. Assim, a problemática mencionada, merece um destaque e olhar interdisciplinares, tendo em vista que abrange aspectos multidimensionais, especialmente se considerarmos que a maioria dos conflitos de terra do Sertão Paraibano, desenvolve-se em torno da área seca de um açude público, ou seja, em função de dois recursos naturais fundamentais à sobrevivência humana no Semiárido: a água e a terra (MOREIRA; TARGINO, 1997, p. 91). Além disso, há outros aspectos 
a serem considerados na educação escolar como o associativismo em área de assentamento ou outras áreas rurais, a história de luta e espacialização e territorialização dessas lutas nas terras conquistadas, as culturas locais, e as metodologias no ensino que subsidiem tais debates.

\section{CONHECENDO $O$ TERRITÓRIO E A ESCOLA, PELA EXTENSÃO E PESQUISA}

A Extensão Universitária é a comunicação que se estabelece entre universidade e sociedade visando à produção de conhecimentos e à interlocução das atividades acadêmicas de ensino e de pesquisa, por meio de processos ativos de formação. Engloba experiências de popularização da ciência e realiza atividades que favorecem a construção de caminhos que podem contribuir no enfrentamento de problemas e questões sociais.

Assim como a extensão, a pesquisa contribui para a descoberta de questões que envolvem o cotidiano investigado e, partir do que se desvela pode-se transformar a realidade investigada tanto pela extensão, como pela contribuição na formação de programas e políticas públicas, dentre outros. Tais projetos de extensão e pesquisa colaboram, dentre outras perspectivas, na promoção da formação inicial e continuada docentes, eixo sobre o qual nos debruçamos ao pensar a Educação do Campo e o seu potencial educador na formação de professores.

A universidade é estruturada a partir do tripé universitário, que abriga ensino, pesquisa e extensão, a partir dos quais o conhecimento se constrói por distintas experiências formativas, abrangendo o público interno e externo a esse universo acadêmico. Segundo a Lei de Diretrizes e Bases da Educação (LDB) (BRASIL: 1996), além do Ensino Superior deve desenvolver, além do ensino e da pesquisa, atividades de extensão respeitando os requisitos estabelecidos por cada instituição. 
SABERES E EXPERIÊNCIAS DE PRATICAS PEDAGÓGICAS NO CONTEXTO EDUCACIONAL

Uma das funções sociais da Universidade é a de contribuir na busca de soluções para os graves problemas sociais da população, formulando projetos pautados em políticas públicas participativas e emancipadoras. Os projetos de extensão universitária são também uma forma de educadores e educandos conhecerem experiências nas áreas de atuação profissional docente. A extensão universitária deve ser formada por professores, alunos e comunidade externa, conforme se preconizou no Projeto de Bolsa Extensão - PROBEX, da UFCG, períodos de 2016 a 2020, com vigência anual. Esses projetos iniciaram em espaços e experiências distintas, porém, todos em escolas públicas e, com o intuito de refletir e colaborar na construção da docência associada aos princípios da política pública da Educação do Campo (CALDART, ARROYO, MOLINA: 2005).

A propositura de extensão inclui o desenvolvimento de oficinas, Diagnósticos Rurais Participativos - DRP para refletir acerca das comunidades e de sua relação com a Escola, um Encontro e uma Mostra Cultural das ações desenvolvidas. A partir das atividades desenvolvidas na extensão está em desenvolvimento à pesquisa para se investigar nos anos de 2019 a 2022 quais ações na formação inicial e continuada docente, as ações educativas interdisciplinares realizadas e, a contextualização no ensino de Geografia, as metodologias, linguagens e os recursos utilizados pela referida Escola, no sentido de promoção da Política de Educação do Campo, com ênfase para a discussão sobre o espaço e território, no lugar dos sujeitos da reforma agrária.

As ações iniciais de pesquisa tiveram como marco inicial o levantamento do estado da arte (Quadro 01) da produção existente acerca da área que abrange a comunidade escolar. 
SABERES E EXPERIÊNCIAS DE PRÁTICAS PEDAGÓGICAS NO CONTEXTO EDUCACIONAL

Quadro 1 - Produção acadêmica existente sobre o espaço que envolve a Escola.

\begin{tabular}{|c|c|c|}
\hline Tipologia & Autor & Título \\
\hline \multirow{5}{*}{$\begin{array}{l}\text { Trabalho de } \\
\text { Conclusão de } \\
\text { Curso - TCC }\end{array}$} & $\begin{array}{c}\text { Francisco Dantas } \\
\text { da Silva }\end{array}$ & $\begin{array}{l}\text { Conflitos pelo Uso e a Ocupação do Solo no } \\
\text { Distrito de Irrigação do Perímetro Irrigado } \\
\text { Várzea de Sousa (DPIVAS), Paraíba. }\end{array}$ \\
\hline & $\begin{array}{l}\text { Raisa Maria de } \\
\text { Sousa Regala }\end{array}$ & $\begin{array}{l}\text { Conquistar a Terra Não é Suficiente: o Uso de } \\
\text { Agrotóxicos pela Empresa Santana e a Luta dos } \\
\text { Assentados do Nova Vida I pela Vida na Terra. }\end{array}$ \\
\hline & $\begin{array}{c}\text { José Avelino da } \\
\text { Silva }\end{array}$ & $\begin{array}{c}\text { Do Território da Esperança à Memória da } \\
\text { Conquista Territorial: Conflitos e Acesso a Terra } \\
\text { pelo MST no Acampamento Emiliano Zapata, } \\
\text { Sousa - PB. }\end{array}$ \\
\hline & $\begin{array}{c}\text { Rafael Dias } \\
\text { Barbosa }\end{array}$ & $\begin{array}{l}\text { Luta e Permanência no Campo: um Estudo } \\
\text { de Caso no Assentamento Nova Vida I, } \\
\text { Sousa - PB. }\end{array}$ \\
\hline & $\begin{array}{c}\text { Moises Ferreira } \\
\text { de Sousa }\end{array}$ & $\begin{array}{c}\text { O Papel das Instituições de Pesquisa no } \\
\text { Processo de Gestão e Infraestrutura do } \\
\text { DPIVAS em Sousa-PB. }\end{array}$ \\
\hline Dissertação & $\begin{array}{l}\text { Arethusa Eire } \\
\text { Moreira de } \\
\text { Farias }\end{array}$ & $\begin{array}{l}\text { Os Incomodados que Resistem: Contradições e } \\
\text { Territorialidades Camponesas no Projeto de } \\
\text { Irrigação Várzea de Sousa Paraíba. }\end{array}$ \\
\hline
\end{tabular}

Fonte: Organizado pelos Autores: 2021.

O levantamento do estado da arte nos revelou a situação na qual se insere a área destinada aos assentamentos rurais da reforma agrária, situada num território diverso, pois se considera território da reforma agrária, mas também configura área de Perímetro Irrigado da Várzea de Sousa - PIVAS (Figura 03), mas, tais comunidades não dispõem de irrigação, a água é um recurso escasso 
SABERES E EXPERIÊNCIAS DE PRÁTICAS PEDAGÓGICAS NO CONTEXTO EDUCACIONAL

e os lotes recebidos são inferiores ao módulo fiscal destinado a uma família camponesa, adotado para a região por motivo de estar em área de perímetro irrigado.

Figura 3 - Mapa de localização do PIVAS nos municípios de Aparecida e Sousa - PB.

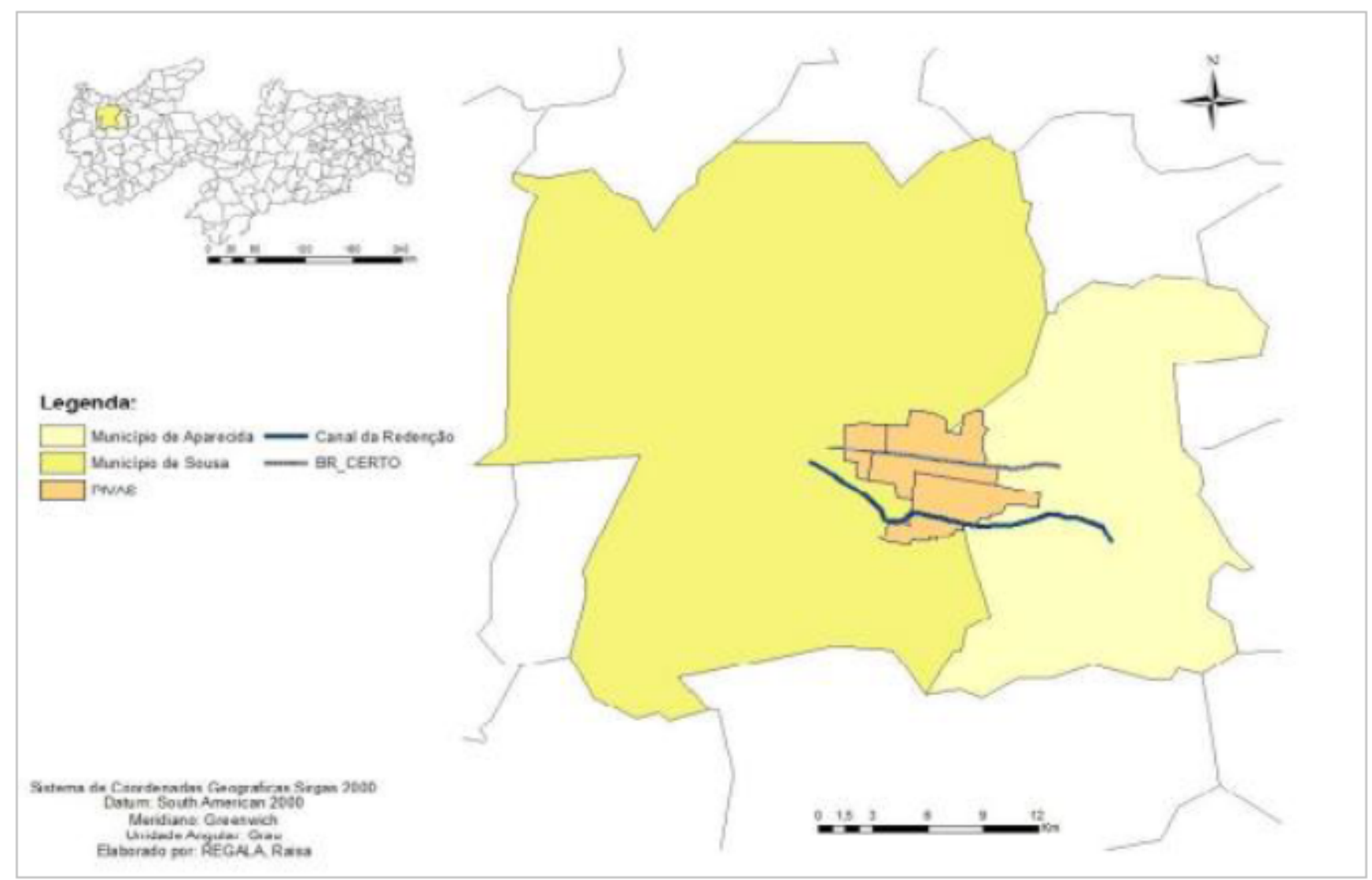

Fonte: Elaborado por Regala: 2014. In.: REGALA: 2014, p. 26.

Igualmente, revelou o interesse de pesquisas no espaço considerado neste trabalho, assim como das relações sociais e institucionais que se dão nesse espaço, assim desvela a problemática que envolve a luta camponesa no Brasil e, na Paraíba em especial, demonstrando que a luta pela terra camponesa ocorre em simultâneo com outras lutas. Dentre elas, a terra, água, o direito a permanecer camponês, a produção de transição agroecológica, contra o projeto neoliberal da promoção de agrotóxicos e de produção em áreas de perímetros irrigados destinados ao agronegócio, sendo todas essas lutas, comuns à outra luta em particular: o direito á Educação do Campo e, a criação e permanência de escola do campo na comunidade onde residem os camponeses, pois defendem que a educação contribui para o fortalecimento da identidade e, do território camponês. 
SABERES E EXPERIÊNCIAS DE PRÁTICAS PEDAGÓGICAS NO CONTEXTO EDUCACIONAL

Os perímetros irrigados têm como proposta um tipo de agricultura que não principia a participação da agricultura familiar e suas organizações, mas a imposição de um modelo de agricultura voltada à promoção do mercado globalizado fortemente apoiado pelo Estado. Conforme Lima (2009), o espaço considerado pelo PIVAS e seu entorno tem marco inicial com a construção do Canal da Redenção, entre os anos de 1997 a 2002, seguido da distribuição de lotes no PIVAS, no ano de 2008, localizado entre os rios do Peixe e Piranhas. Foi implantado com a estrutura hídrica necessária ao seu funcionamento e seu objetivo foi desenvolver fruticultura irrigada para exportação, além de leguminosas e grãos (Figura 04).

Figura 4 - Primeira planta dos estudos preliminares do PIVAS: 1997. Projeto de Aproveitamento Hidro-agrícola das Várzeas de Sousa (Estudos preliminares).

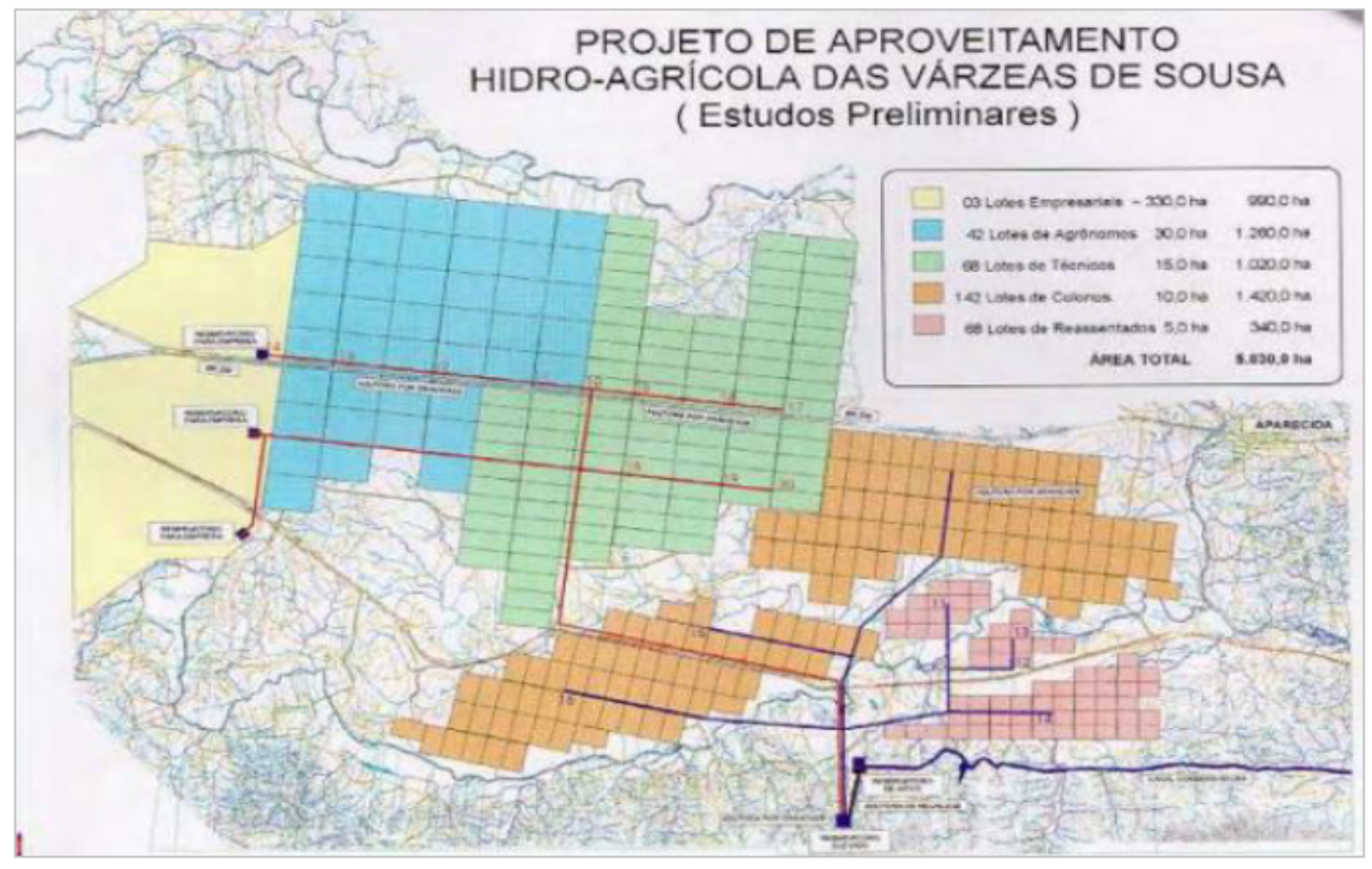

Fonte: Semarh: 1997. In: Farias: 2010, p.58.

O conhecimento geocartográfico do espaço do PIVAS e o conhecimento sócio espacial do Assentamento Nova Vida I e da Escola revela um espaço de contradições, sobretudo se observarmos as disputas por terra numa área de perímetro irrigado no Semiárido Nordestino. 
SABERES E EXPERIÊNCIAS DE PRATICAS PEDAGÓGICAS NO CONTEXTO EDUCACIONAL

Entendemos que no Brasil, a luta camponesa e nela, a luta por educação, nasce com a luta pela terra, esta que tem um processo histórico, desde a formação do Brasil Colonial quando os sujeitos da terra foram violentamente expropriados e tiveram seus direitos negados. Conforme Lima (2006, p. 23), a ocupação, conquista e permanência no campo pelos excluídos/expropriados do acesso a terra se dá, sobretudo pelo processo lutas contra a formação e consolidação da estrutura agrária de distribuição desigual de terras no Brasil. Desde os primórdios da colonização, a distribuição desigual das terras do território brasileiro foi realizada de forma excludente, inicialmente com as Capitanias Hereditárias e seus donatários e, posteriormente, com doação de terras em Sesmarias, dando origem aos grandes latifúndios no País.

A Lei de Terras, $n^{\circ}$ 601/1850 (BRASIL: 1850), põe fim à doação de terras, no entanto o acesso à terra só passa a ser possível através da compra e venda em dinheiro, legitimando a permanência do grande latifúndio e excluindo a possibilidade de todos terem acesso igualitário a terra para produzir. De acordo com MOREIRA (1990, p. 10) e MOREIRA; TARGINO (1997), durante o processo de ocupação do Sertão Paraibano os rios constituíam as principais vias de penetração. A facilidade de circulação e a distribuição de águas condicionaram a ocupação das margens fluviais e produziram o povoamento de ribeira. Isto é, a instalação de grandes fazendas de gado próximo aos rios. Além do gado, outro produto que fez parte do processo de consolidação dos grandes fazendeiros latifundiários no Sertão da Paraíba foi o algodão, que no fim do século XVIII, passou a ser o produto de maior importância econômica na agricultura paraibana.

A apropriação da terra por grandes latifundiários, principalmente no Sertão da Paraíba, culminou em intensas lutas por distribuição igualitária e justa da terra, a exemplo do processo de luta e conquista de propriedades rurais, hoje transformadas em Assentamentos Rurais da Reforma Agrária, após intensos conflitos pela posse da terra. De acordo com MOREIRA (1997, p. 178), o "conflito de terra é fruto do choque de interesses entre capital e trabalho representado, de um lado, pela necessidade de subordinação da produção à lei do lucro e, do outro, 
SABERES E EXPERIÊNCIAS DE PRÁTICAS PEDAGÓGICAS NO CONTEXTO EDUCACIONAL

pelo direito de permanecer na terra, de viver na terra e garantir a sobrevivência de unidade familiar produtiva".

Considerando o histórico de enfrentamentos e despejos realizados pela justiça junto aos agricultores que lutam pela terra nos assentamentos rurais ou mesmo, os que lutam para permanecer na terra, ou seja, somado ao histórico das lutas pela permanência na terra conquistada, a luta no Assentamento Nova Vida I e, nos demais assentamentos que compõem a comunidade da Escola Renê Alves Ramalho, nascem no bojo das ações do Estado para fortalecer o modelo do agronegócio e, contra esse modelo, os camponeses resistiram e se rebelaram na luta por terra.

Para os sujeitos do campo que lutam pela reforma agrária a luta por terra inicia com outras lutas, em especial, a luta por educação que seja feita para e com eles mesmos. Assim nasce o Movimento Por Uma Educação do Campo ${ }^{1}$. A conquista de uma escola no Assentamento Nova Vida demarca a territorialização da luta por educação, e a presença do MST na gestão da escola reafirma os princípios da Política da Educação do Campo.

A história do Assentamento Nova Vida I, tem seu marco inicial de luta no ano de 2004, com a reivindicação por terra e pela água, em área do Perímetro Irrigado das Várzeas de Sousa (PIVAS), Paraíba. Sua configuração diversificada atende a vários propósitos. Criado pelo Estado, o PIVAS se forma a partir das estratégias do Governo Federal em parceria com o Governo do Estado da Paraíba com o objetivo inicial de atender a região do Sertão com uma atividade agroindustrial associada aos interesses transnacionais.

O PIVAS foi antecedido pelo Perímetro Irrigado de São Gonçalo - PISG, este que apresenta debilidades econômicas e técnicas em sua gestão (FRANÇA: 2021). Conforme a distribuição das áreas do PIVAS realizada pelo Estado há uma demonstração dos interesses das classes dos proprietários dos meios de produ-

1 O movimento "Por uma educação do campo" é um coletivo nacional constituído por diferentes movimentos sociais do campo que debatem e discutem uma proposta de educação para a população do campo que prime pelas suas especificidades culturais, sociais e econômicas. Suas proposições estão representadas aqui pelo texto de Caldart, Arroyo, Molina: 2005. 
SABERES E EXPERIÊNCIAS DE PRÁTICAS PEDAGÓGICAS NO CONTEXTO EDUCACIONAL

ção e de capitalistas, numa soldagem destas com o Estado, representada pela concentração da propriedade da terra e da água na mão de poucos, enquanto é destinada pouca terra para grandes contingentes de trabalhadores (Quadro 02).

Quadro 2 - Divisão dos lotes do antigo projeto do PIVAS

\begin{tabular}{|c|c|c|}
\hline \multicolumn{3}{|c|}{ Divisão dos lotes no antigo do Projeto de Irrigação Várzeas de Sousa (Pivas) } \\
\hline Classes contempladas & Tamanho dos lotes (ha) & Total de hectares \\
\hline 03 Lotes empresariais & 330 ha & 990 ha \\
\hline 142 lotes para colonos & 10 ha & 1.420 ha \\
\hline 42 lotes para agrônomos & 30 ha & 1.260 ha \\
\hline 68 lotes para técnicos & 15 ha & 1.020 há \\
\hline 58 lotes para reassentados & 5 ha & 340 há \\
\hline \multicolumn{2}{|c|}{ Total: } & 5.030 há \\
\hline
\end{tabular}

Fonte: Governo do Estado da Paraíba. Semarh. Org. por Farias, A. E. M.. In.: FARIAS (2010, p.61).

A distribuição apresentada pelo Estado foi contestada pelos movimentos sociais do campo para que houvesse reforma na proposta de distribuição dos lotes na área do PIVAS (Figuras 05 e 06).

Figuras 5 e 6 - Mobilização de luta pela reforma agrária em 24/06/2004, na BR-230.
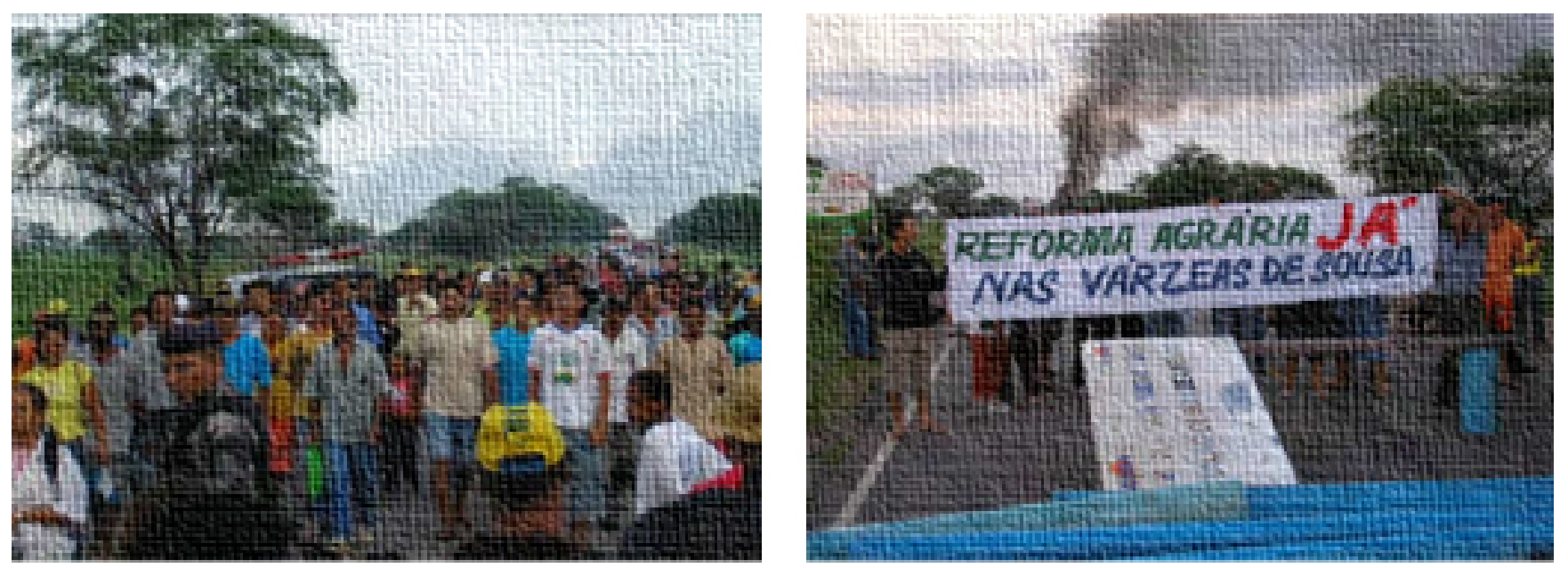

Fonte: CPT: 2004. In.: Farias (2010, p. 66). 
SABERES E EXPERIÊNCIAS DE PRÁTICAS PEDAGÓGICAS NO CONTEXTO EDUCACIONAL

Segundo Regala (2014, p. 36),

A luta pela terra que deu origem ao assentamento Nova Vida I teve inicio no ano de 2004, com a CPT Sertão e a formação do Acampamento Nova Vida I, inicialmente composto por 400 famílias dentre as quais, muitas que tinham sido expropriadas para a construção do Canal da Redenção. A existência de conflitos sociais de luta pela terra no entorno do PIVAS reflete a reação do campesinato contra a concentração fundiária e a concentração da água nas mãos dos grandes proprietários.

Como uma demonstração de resistência característica do campesinato se organizou uma mobilização na BR-230 com a presença dos trabalhadores e trabalhadoras do campo, em luta pela terra, apoiados por movimentos sociais e entidades, os quais exigiam reforma agrária nas várzeas de Sousa, na Paraíba, o que gerou mudança na distribuição da área (Quadro 03).

Quadro 3 - Atual divisão dos lotes do PIVAS

\begin{tabular}{|c|c|c|}
\hline \multicolumn{2}{|c|}{ Atual divisão dos lotes do Projeto de Irrigação Várzeas de Sousa (Pivas) } \\
\hline Classe contemplada & Tamanho dos lotes (há) & Total (ha) \\
\hline $\begin{array}{c}16 \text { lotes empresariais } \\
\text { produtores }\end{array}$ & 144 há & $2.307,38$ \\
\hline $\begin{array}{c}\text { 178 lotes para } \\
\text { assentamento do Incra }\end{array}$ & 5 ha & 992,63 \\
\hline $\begin{array}{c}2 \text { lotes da Emepa } \\
\text { 1 lote da Escola } \\
\text { de Sousa (EAFS) }\end{array}$ & 15 há há & 998,75 \\
\hline $\begin{array}{c}16 \text { lotes com baixa } \\
\text { aptidão para irrigação }\end{array}$ & 10 ha & 30,00 \\
\hline \begin{tabular}{c} 
Reserva legal \\
\hline
\end{tabular} & $1.267,18$ há & 10,00 \\
\hline
\end{tabular}


SABERES E EXPERIÊNCIAS DE PRÁTICAS PEDAGÓGICAS NO CONTEXTO EDUCACIONAL

\begin{tabular}{|c|c|c|}
\hline $\begin{array}{c}\text { Área de preservação } \\
\text { permanente }\end{array}$ & 206,57 ha & 206,57 \\
\hline $\begin{array}{c}\text { Área de infraestrutura } \\
\text { e inaproveitáveis }\end{array}$ & 443,23 há & 443,23 \\
\hline \multicolumn{2}{|c|}{ Total: } & $6.335,74$ \\
\hline
\end{tabular}

Fonte: Governo do Estado da Paraíba. Semarh. Organizado por Farias, A. E. M.. In.: FARIAS (2010, p.61).

Essa luta camponesa abrigou dois importantes recursos: terra e água para produzir, morar, viver; com dois importantes apoiadores: o Movimento dos Trabalhadores e Trabalhadoras Rurais Sem Terra (MST) e, a Comissão Pastoral da Terra (CPT) - Sertão; dois significativos territórios móveis de acampamentos da reforma agrária: Acampamento Nova Vida I com 400 famílias Sem Terras e o Acampamento Renascer.

A luta do Acampamento Nova Vida I, apoiado pela CPT-Sertão se soma, em 2006 ao acampamento Renascer, apoiado pelo MST. Juntos perfizeram movimentos que englobavam, segundo Regala (ibidem) "passeatas; ocupação da BR/230; ocupação do Instituto Nacional de Colonização e Reforma Agrária - INCRA etc., buscando sensibilizar o Estado para o atendimento de suas reivindicações".

Após sucessivos enfrentamentos dos camponeses, do MST e da CPT-Sertão ao Estado para que houvesse regularização de cessão de lotes do PIVAS às famílias acampadas, obtiveram êxito quando ocorreu a concessão da terra na área reivindicada com 1007,3 hectares para a atenção a 141 famílias Sem Terras.

No dia 20 de outubro de 2010, ocorreu a cessão de 1.007 hectares do PIVAS para a instalação do PA Nova Vida I. Formalmente, porém o Assentamento só foi criado em 24 de janeiro de 2011. Depois de criado, deu-se a divisão da terra em lotes. Sobraram 48 lotes, que, segundo o entrevistado, a CPT queria distribuir com famílias que não participaram da luta. Todavia, eles, em solidariedade com as famílias do Acampamento Renascer, decidiram convidar os companheiros de luta. (REGALA: 2014, p. 36). 
Embora as famílias estejam em área de perímetro irrigado a situação de luta pela água continua flagrante numa área circunscrita ao Semiárido brasileiro (Figura 07).

Figura 7 - Família realizando abastecimento de água em transporte animal.

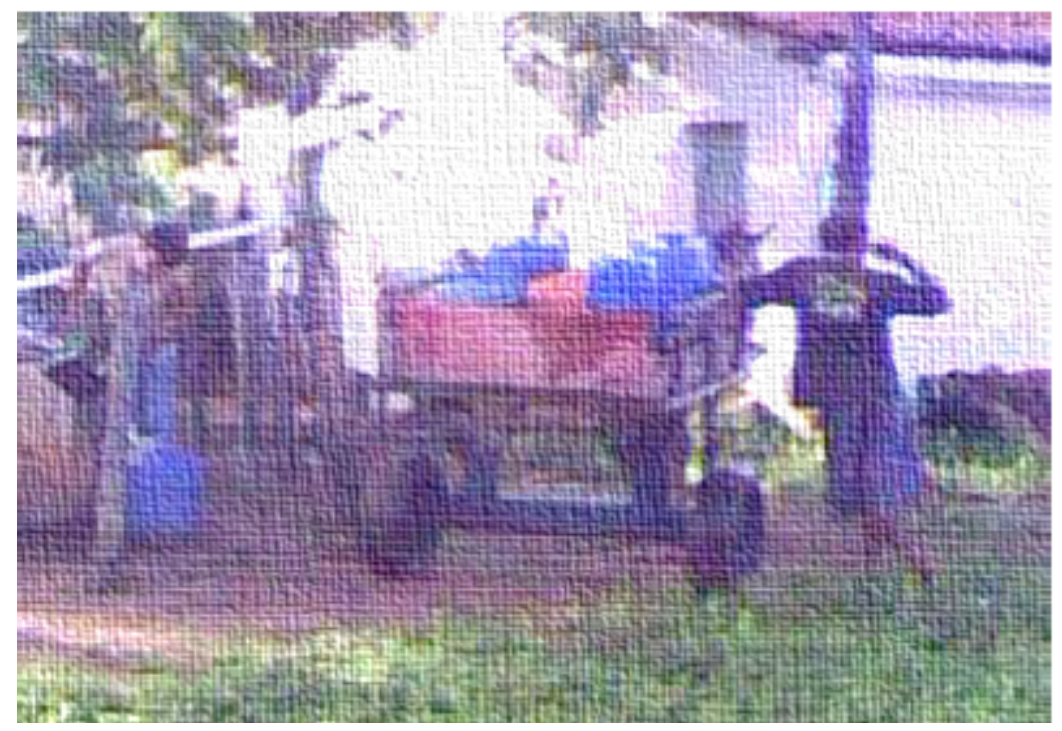

Fonte: Barbosa (2011). In.: BARBOSA: (2011, P. 25).

Os camponeses conquistaram o território, mas outras lutas são necessárias a fim de que haja condições de permanência na terra conquista, a exemplo de um projeto educacional que respeite suas diversidades e peculiaridades.

\section{A EDUCAÇÃO DO CAMPO E A TERRITORIALIZAÇÃO DA COMUNIDADE NOVA VIDA I E SEU ENTORNO}

A concepção de uma educação a partir do campo e no campo foi formulada em um contexto de problematização de conceitos e ideias até então arraigados na sociedade brasileira, como tem sido o de Educação Rural. A concepção de Educação do Campo, em substituição à Educação Rural, entende campo e cidade enquanto duas partes de uma única sociedade, que dependem uma da outra e não podem ser tratadas de forma desigual.

A concepção de educação que historicamente pautou as iniciativas educacionais para o meio rural fundamenta-se, principalmente, na categorização 
urbano/rural, na qual o espaço rural é definido, de acordo com critérios do IBGE, pela sua localização geográfica e, a baixa densidade populacional; por um projeto de desenvolvimento centrado nas atividades urbano-industriais, segundo o qual o campo tenderia ao desaparecimento, não sendo pertinente, portanto, o investimento em políticas estruturantes nesse espaço; pela concepção de rural enquanto espaço tipicamente de atividades agrícolas, priorizando o latifúndio.

A Educação do Campo é uma área de conhecimento que está associada à possibilidade de implementações de proposições instituídas de princípios políticos, pedagógicos e didáticos sobre o saber inerente as áreas de conhecimentos. Prima por uma educação voltada à realidade dos sujeitos do campo e a formação de professores-educadores aptos para atuarem nessas escolas, além da formação docente, que habilite o docente a trabalhar os conteúdos e construir currículos que atendam as demandas pedagógicas do Ensino Fundamental e Ensino Médio. (Gaia \& Pires, 2016, p. 4)

Segundo Barbosa (2011, p. 26),

A educação no Assentamento Nova Vida I não oferece os recursos para uma boa qualidade de ensino para as pessoas que ali vivem, a situação da sala de aula precisa melhorar bastante, pois o local não tem nenhuma ventilação e isso dificulta a aprendizagem dos educandos que dependem daquele local para assistir suas aulas, os educadores infelizmente não são capacitados, mas mesmo com todas as dificuldades existentes no local as famílias agradecem as aulas que recebem porque contribui bastante para essas pessoas que não tem oportunidade de se deslocar até a cidade para estudar e como os professores também residem no assentamento fica mais fácil dar aula para os seus alunos.

Para o autor (ib. id., p. 27),

O material escolar é fornecido pelo governo, mas não atende as necessidades dos alunos que estudam no assentamento. Muitas vezes, os professores do assentamento, mesmo sem nenhuma formação acadêmica buscam ministrar suas aulas de uma maneira diferente como fora da sala de aula mostrando a vegetação existente no local para as crianças do assentamento, também chama a atenção às condições das cadeiras que são utilizadas por eles, as mesmas encontram-se em situação precária e não oferecem conforto para os estudantes. 
Figura 8: Sala de aula no Acampamento Nova Vida I. Sousa-PB.

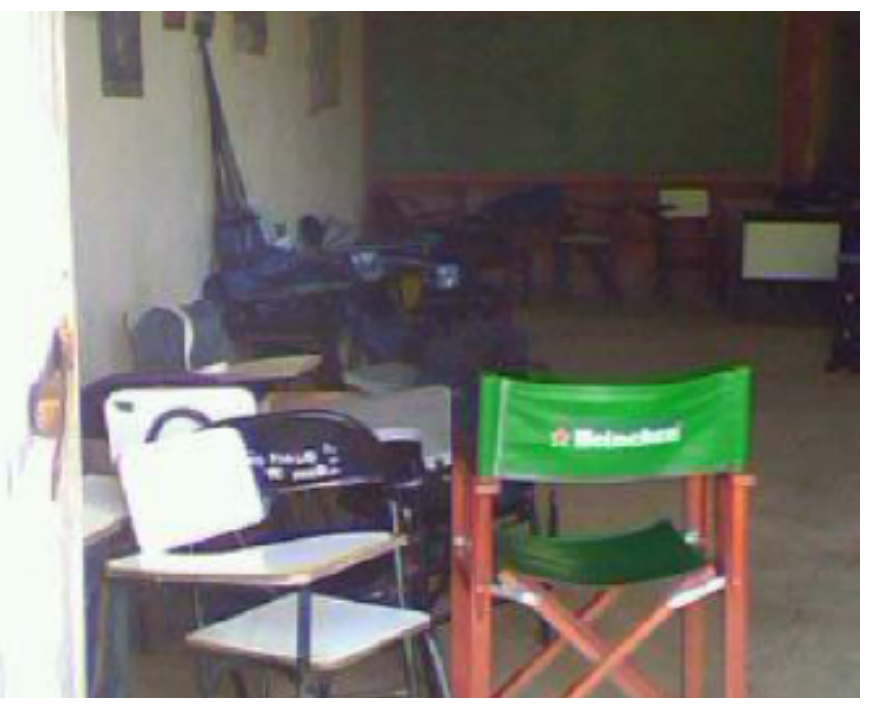

Fonte: Barbosa: 2011, p.27.

O espaço destinado ao encontro é considerado lugar de sociabilidades diversas no acampamento Nova Vida I: cooperativa de mulheres, lugar de cultos religiosos, escola e centro de reuniões.

Figuras 9 a 12 - Espaço comunitário de ações sociais no Acampamento.
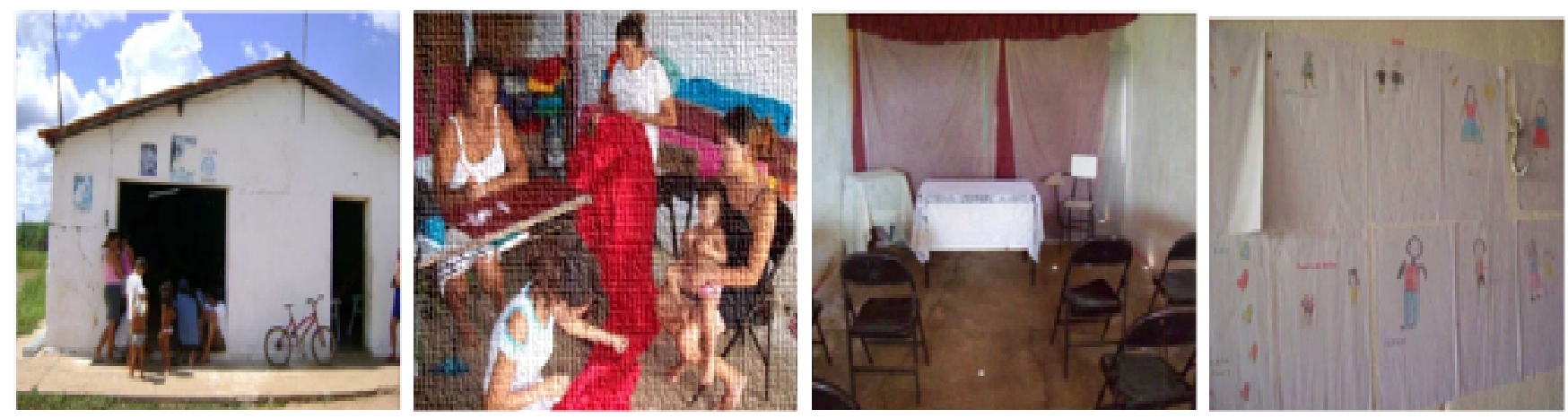

Fonte: Farias A. E. M. 2009. In.: FARIAS: 2010, p. 72.

De acordo com Barbosa (2011, p. 27), ao entrevistar a Sra MG, a mesma afirma que no momento inicial do acampamento, a educação não se constituía um reconhecimento ao direito dos povos do campo de estudar em sua comunidade e sobre suas realidades, conforme principia a Política da Educação do Campo:

O ensino no assentamento para os jovens estudarem é difícil porque uma parte precisa se deslocar ao município de Sousa e outra para Aparecida, 
SABERES E EXPERIÊNCIAS DE PRÁTICAS PEDAGÓGICAS NO CONTEXTO EDUCACIONAL

\begin{abstract}
a prefeitura de Sousa disponibiliza um ônibus para levar os estudantes ate a escola e trazê-los de volta para o assentamento, existe também um ônibus que leva os estudantes para a escola em Patos e Sousa no horário da manhã e da tarde, as crianças estudam pertinho do assentamento, mas também necessitam de um transporte para as levarem até a escolinha. (ib. id., p. 27).
\end{abstract}

As crianças e adolescentes são em muitas realidades do campo, costumeiramente realocadas para a cidade para os estudos e o modelo educacional atende a perspectiva urbanocêntica, por conseguinte negando as realidades camponesas. No Assentamento Nova Vida I houve resistência para fundar a escola.

Considerando essa realidade nosso interesse se justifica por pensar a educação transformadora, conforme preconiza e interdisciplinaridade e a Política da Educação do Campo considerando o necessário reconhecimento pela escola acerca de como ensinar, o que ensinar e para quem ensinar Geografia e História na Escola, especialmente em se tratando de crianças e adolescentes camponeses, sendo a história da luta pela terra um importante tema gerador no debate educacional para as escolas do campo.

A referida Escola abrange educandos de três áreas camponesas, sendo dois assentamentos rurais: Nova Vida e Imaculada; e um Pré-Assentamento, o Emiliano Zapatta. Essas comunidades circunscrevem a realidade camponesa, expropriada e explorada do campo paraibano, e que até fevereiro de 2019 não dispunha do direito a gozar da Política Pública da Educação do Campo.

Situar essas questões traduz-se um ponto de pauta nas Associações Rurais, nas quais as crianças e jovens nem sempre participam, pois a atividade do campo nem sempre tem visto as questões relativas à sucessão familiar no campo. Igualmente, na Escola nem sempre se vê uma preocupação no tocante à aproximação da realidade dos sujeitos com os conteúdos abordados.

As Oficinas pedagógicas propostas nos projetos têm o intuito de refletir sobre as práticas pedagógicas desenvolvidas pelos/as educadores/as, como se 
efetiva a educação nas escolas dos assentamentos e discutindo as concepções e os documentos que regulamentam as políticas e os programas de Educação do Campo: Parecer CNE/CEB 36/2001 e na Resolução CNE/CEB 1, de 3 de abril de 2002 que instituem as Diretrizes Operacionais para a Educação Básica nas escolas do Campo (BRASIL: 2002b), o Decreto n 7.352, de 4 de novembro de 2010. Resultou em distintas ações e atividades desenvolvidas pela equipe de extensão na E.E.E.F. Renê Alves Ramalho.

Figuras 13 a 15- Semana da Criança - Participação da Equipe na Oficina de Teatro e Oficina de Contação de Histórias
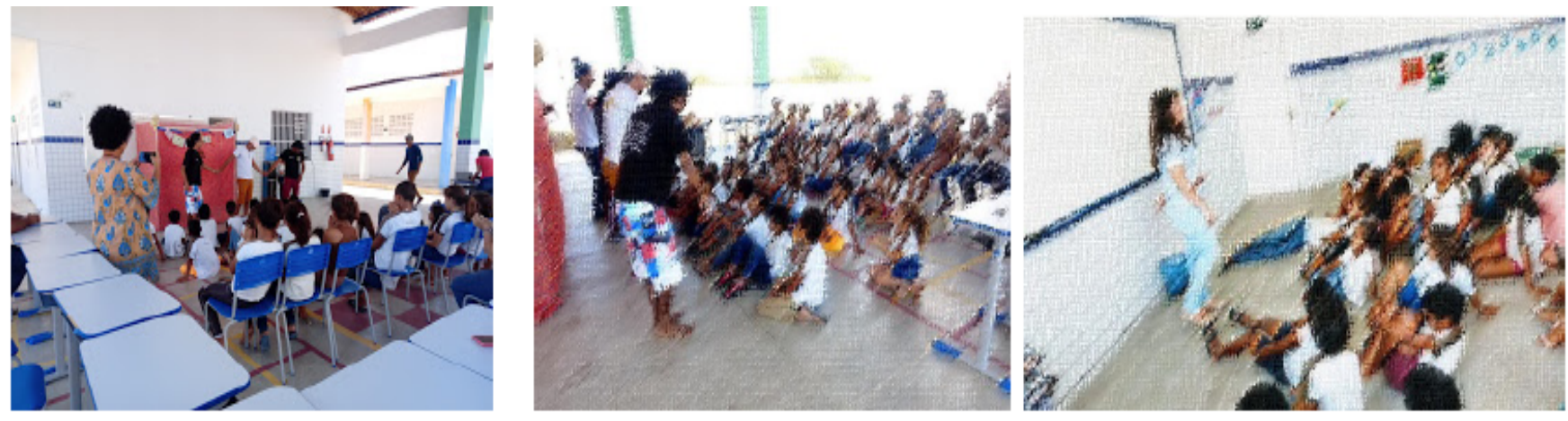

Fonte: Arquivo PROBEX UFCG: 2019.

Figuras 16 a 18 - Oficina de Circo, brincadeiras infantis e de valorização da infância camponesa na EEEF Renê Alves Ramalho
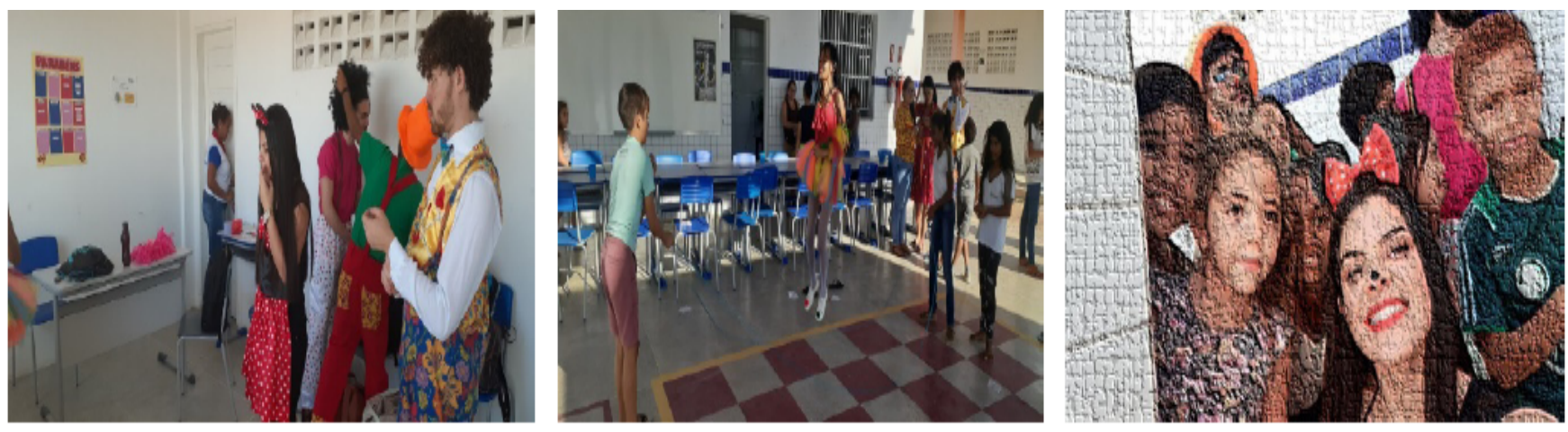

Fonte: Arquivo PROBEX UFCG: 2019. 
Figuras 19 e 20- Participação com apresentação de trabalho sobre a extensão e pesquisa durante o IV EPPEC-PB.
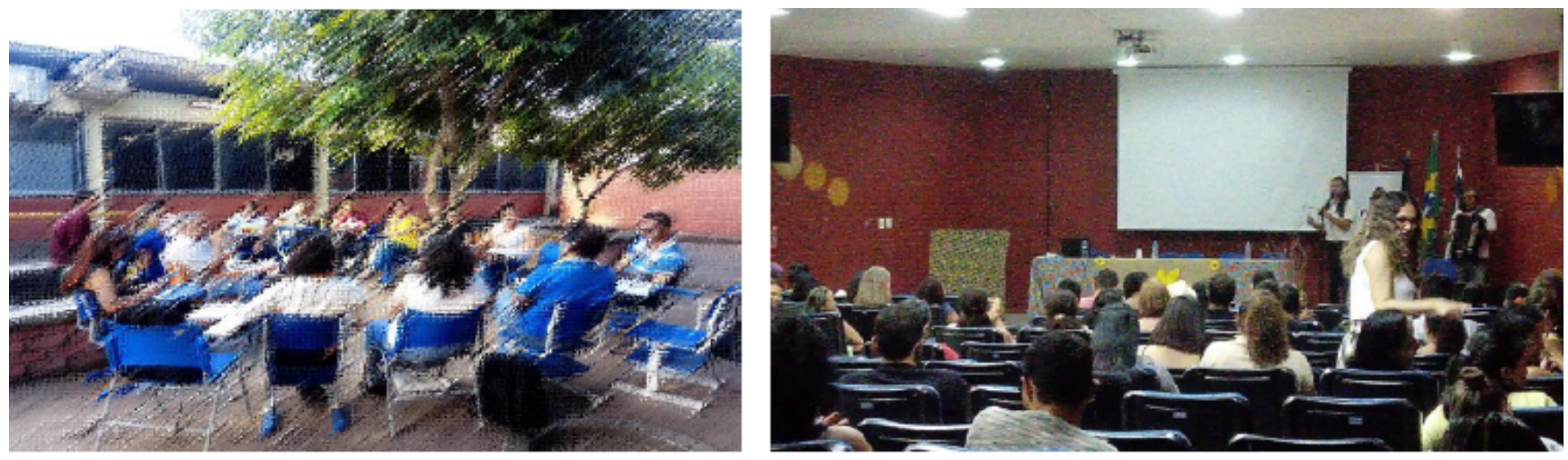

Fonte: Arquivo PROBEX UFCG: 2019.

Figuras 21 a 26- Estudo do meio realizado na Escola Nossa Senhora do Carmo - Bananeiras - PB. Conhecendo a experiência de educação transformadora pautada na experiência da Escola da Ponte, de Portugal.
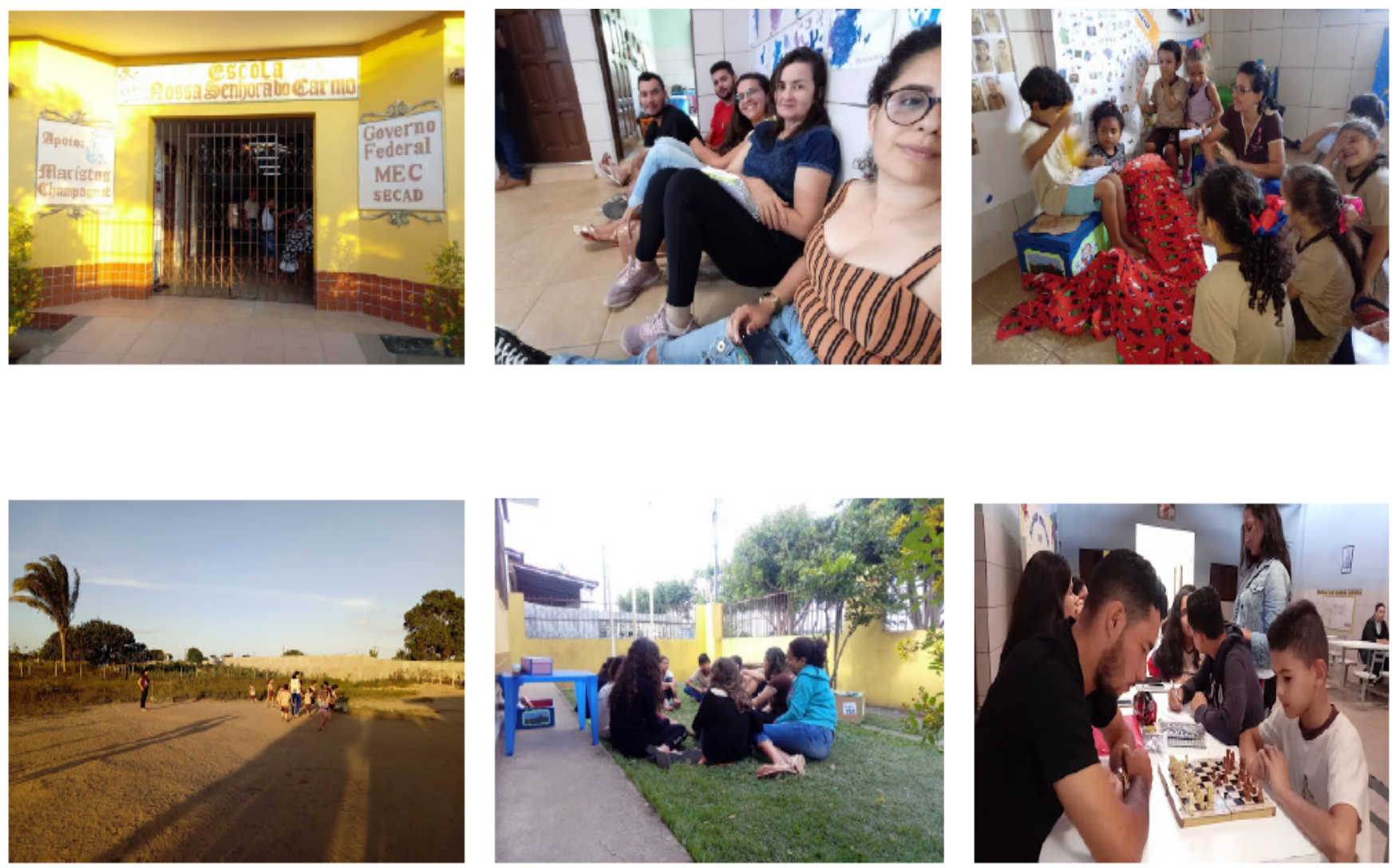

Fonte: Arquivo PROBEX UFCG: 2019. 
Figuras 27 e 28 - Participação com trabalho e ministração de oficina durante o IX SINGA- IX Simpósio Internacional de Geografia Agrária, X Simpósio Nacional de Geografia Agrária.
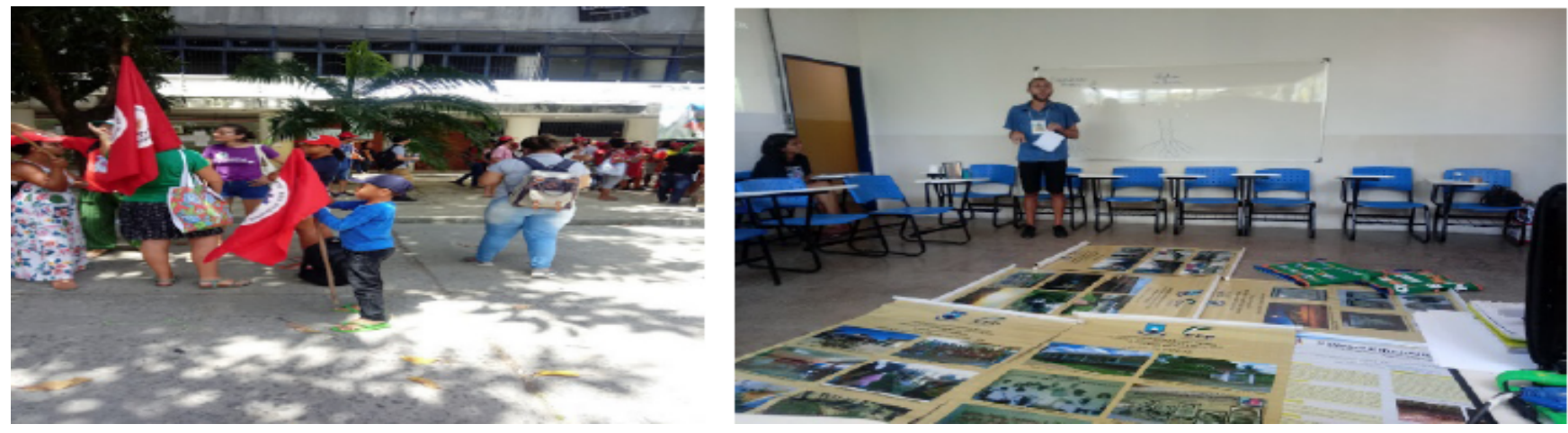

Fonte: Arquivo PROBEX UFCG: 2019.

Realização de Estudo do Meio, em dezembro de 2019, para produção de vídeo documentário nas áreas de acampamentos que originaram o Assentamento Nova Vida I.

Figuras 29 a 31 - Primeiro local de realização do Acampamento da comunidade Nova Vida I- Fazenda Acauã - Aparecida - PB.
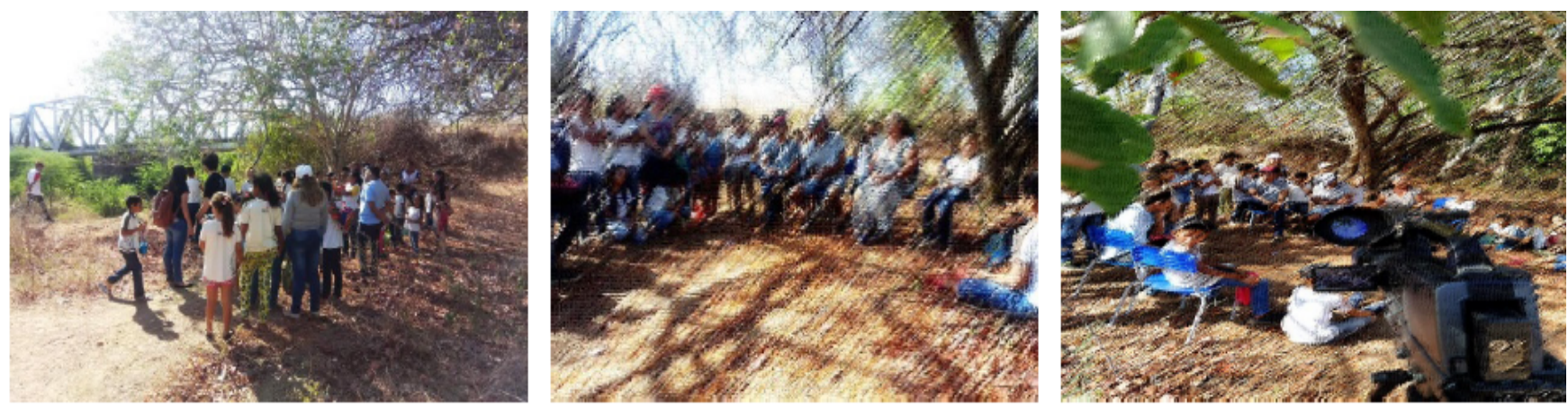

Fonte: Arquivo PROBEX UFCG: 2019.

Figuras 32 a 35 - Visita ao Patrimônio Cultural da Fazenda Acauã - Aparecida PB. Local do Primeiro acampamento da comunidade Nova Vida I.
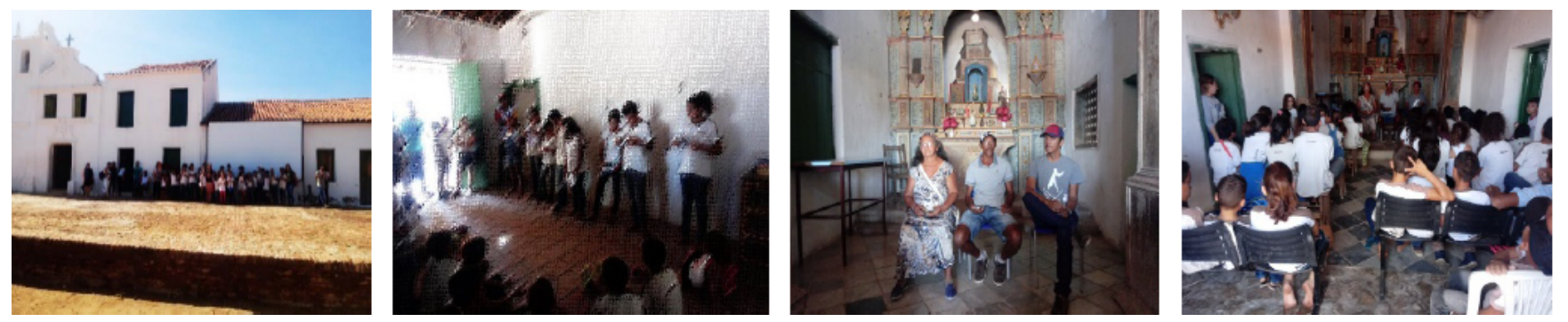
Figuras 36 a 39 - Segundo local de realização do Acampamento da comunidade Nova Vida I- Fazenda Acauã - Aparecida - PB.
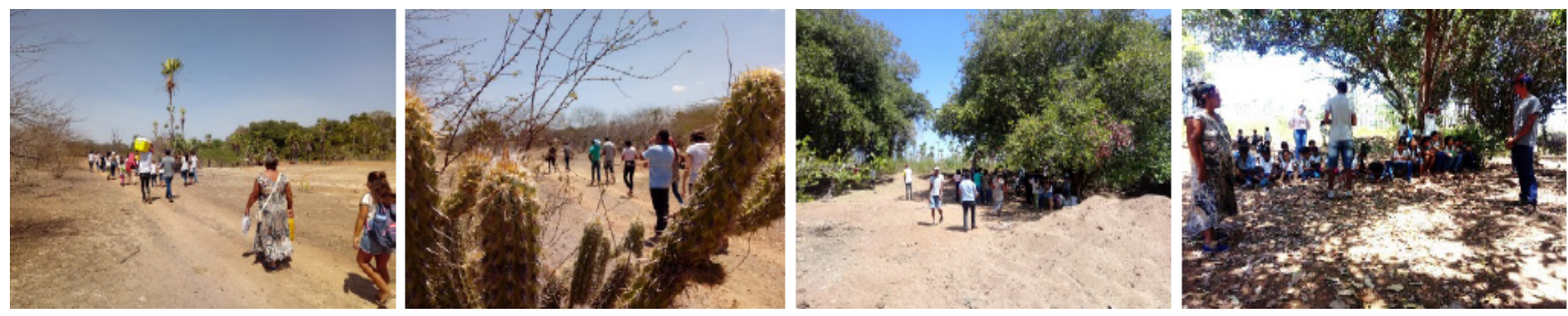

Fonte: Arquivo Probex 2019.

$\mathrm{Na}$ atualidade a escola permanece lutando para permanecer em funcionamento, pois há proposta do Estado de fechar a escola devido ao número de alunos existente. Por outro lado, o município circunvizinho interessa municipalizar a escola. A pauta contínua dos camponeses junto ao MST é de permanência da escola aberta e mais fortalecida com reivindicações constantes ao Estado para que sejam atendidas as reivindicações para o funcionamento adequado da escola partindo da Política Nacional de Educação do Campo.

\section{CONSIDERAÇÕES}

Os estudos têm demonstrado que as comunidades que circunscrevem a E.E.E.F. Renê Alves Ramalho estão em constante luta e organização popular, sobretudo, no tocante à escola, contam com o apoio do MST na proposição de uma escola diferenciada que se paute na história dos sujeitos da comunidade, assim como que esteja em construção com o envolvimento da própria comunidade.

A execução de projetos de extensão e pesquisa trazem contribuições para a escola e a academia tendo em vista a formação simultânea de educandos e educadores, além de atividades de docência compartilhada.

Os Projetos colaboraram na aproximação da Universidade com a Escola e Comunidade, ao passo em requer a continuidade dos mesmos para fins de conclusão das etapas propostas já que algumas tiveram certa dificuldade em função de estarmos em tempos de pandemia. Contudo, no período anterior à esta pu- 
demos realizar atividades presenciais, sobretudo porque o projeto de pesquisa caminhou em simultaneidade ao projeto de extensão de mesmo nome.

$\mathrm{Na}$ atualidade a escola enfrenta outras lutas pelo direito de permanecer aberta e com os educandos estudando na comunidade, além de continuar buscando um projeto almejado pelos movimentos sociais. Em andamento estão a construção da história da escola, do Projeto Político Pedagógico - PPP e, de redes sociais.

\section{REFERENCIAS}

BARBOSA, Rafael Dias. Luta e permanência no campo: um estudo de caso no assentamento Nova Vida I, no município de Sousa - PB. Trabalho de conclusão de curso de Geografia. UEPB: 2014.

BRASIL. Conselho Nacional de Educação. Parecer CNE/CEB 36/2001.

. Lei de Terras de 1850. Dispõe sobre as terras devolutas do Império. Disponível em: http://www.planalto.gov.br/ccivil_03/leis/l0601-1850.htm. Acesso em 10 de outubro de 2021.

. Lei de Diretrizes e Bases da Educação Nacional, 1996: Nova LDB (Lei nº 9394). Rio de Janeiro: Qualitymark, 1996.

. Resolução CNE/CEB n.01, de 18/02/2002. 2002.

. Diretrizes Operacionais para a Educação Básica nas Escolas do Campo. Resolução n 01, de 03 de abril de 2002.

CALDART, R. S.; ARROYO, Miguel Gonzalez; MOLINA, Mônica Castagna (Orgs.). Por Uma Educação do Campo. Petrópolis: Vozes, 2005. v. 1.

DINIZ, A. S. A construção dos perímetros irrigados e a criação de novas territorialidades. In: Elias D, Sampaio JLF, organizadores. Modernização excludente. Fortaleza: Demócrito Rocha; 2002.

FARIAS, Arethusa Eire Moreira de. Os Incomodados que resistem. Dissertação de Mestrado defendida no PPGE/UFPB. João Pessoa: 2010. 
FERNANDES, Bernardo Mançano, MOLINA, Mônica C. O Campo da Educação do Campo. In: MOLINA, Mônica Castagna, JESUS, Sônia M. S. Azevedo de (Orgs.). Contribuições para a construção de um projeto de educação do campo. Vol. 5. Brasília, 2004.

FERRANTE, Vera Lúcia Silveira B. Assentamentos Rurais: Estratégias de Recusa ao Modelo Estatal? Raízes, Ano XVI, No 15,dez./1997. Disponível em: http://www.ufcg.edu.br/ raizes/. Acesso em 05/06/2009

FRANÇA, Wanessa Silva de. A Construção do Território no Perímetro Irrigado de São Gonçalo (PISG), Sousa, Paraíba. Monografia de Graduação em Geografia. UFCG: Cajazeiras: 2021.

GAIA, Carlos, \& PIRES, Lucas Silva. Saberes matemáticos e história de vida na zona rural de Marabá-PA. 2016. Disponível em: https://sistemas.uft.edu.br/ periodicos/index.php/campo/article/view/2260/11830. Acesso em: 20 de agosto de 2021.

LIMA, Valéria R. P. Gestão dos Recursos Hídricos: Conflito e Negociação da Águas do Canal da Redenção - Sertão da Paraíba. João Pessoa. Abril de 2009.

MOREIRA, Emília de Rodat Fernandes. Evolução do Processo de Ocupação do Espaço Paraibano. Textos UFPB / NDIHR № 24 set/1990. Disponível em: http://www.ndihr.ufpb.br/programa/processo_de_ocupacao.html. Acesso em: 20 de agosto de 2021.

; TARGINO, Ivan. Capítulos de Geografia Agrária da Paraíba. João Pessoa: Editora Universitária/UFPB. 1997. 332p.

REGALA, Raisa Maria de Sousa. Conquistar a terra não é suficiente: o uso de agrotóxicos pela empresa Santana e a luta dos assentados do Nova Vida I pela vida na terra. Monografia apresentada ao curso de Geografia na UFPB. João Pessoa: 2014. 

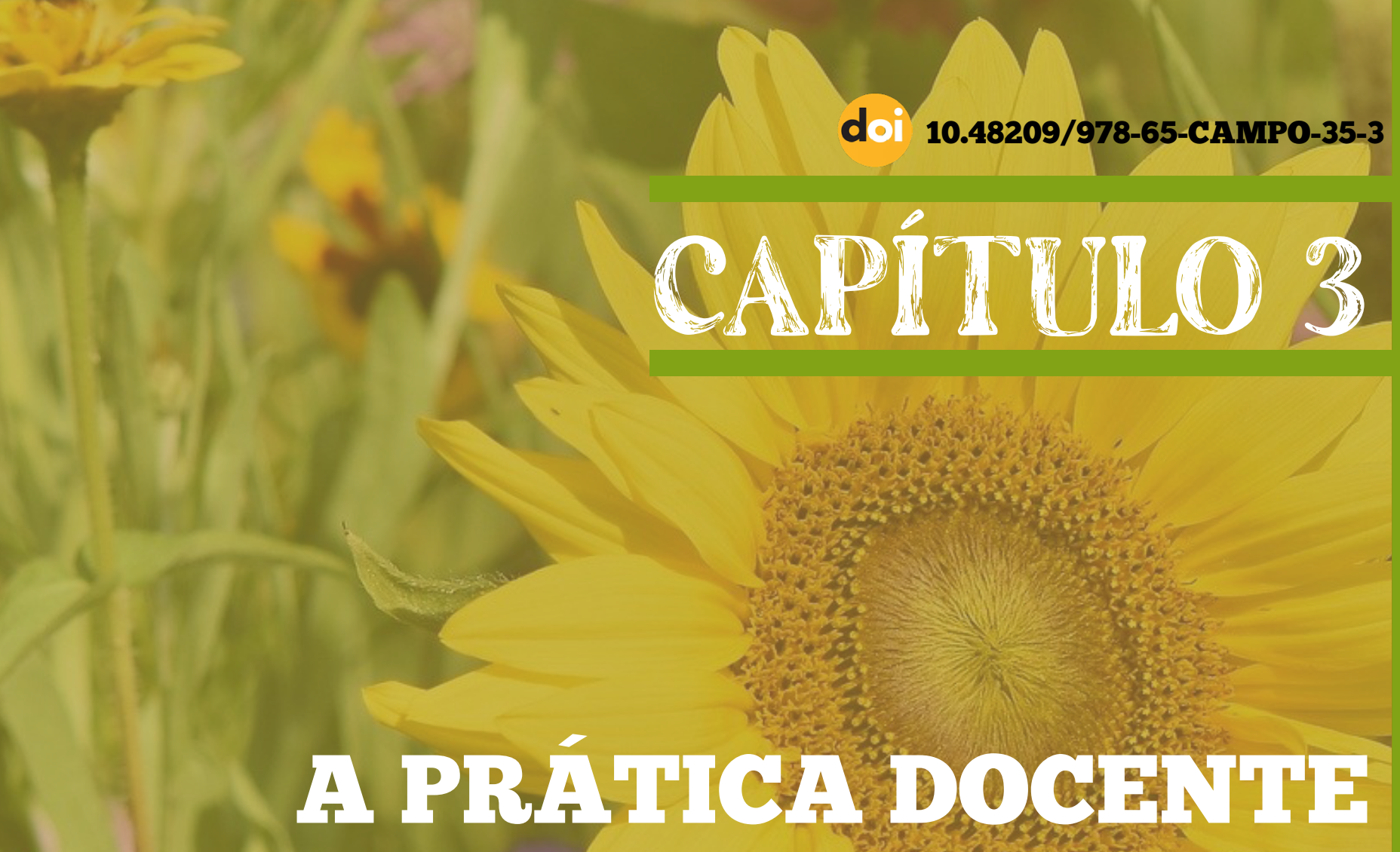
NA MULILLSERTAÇ UM ESTUDO DE CASO EM UMA BSCOLA DO CAMPO
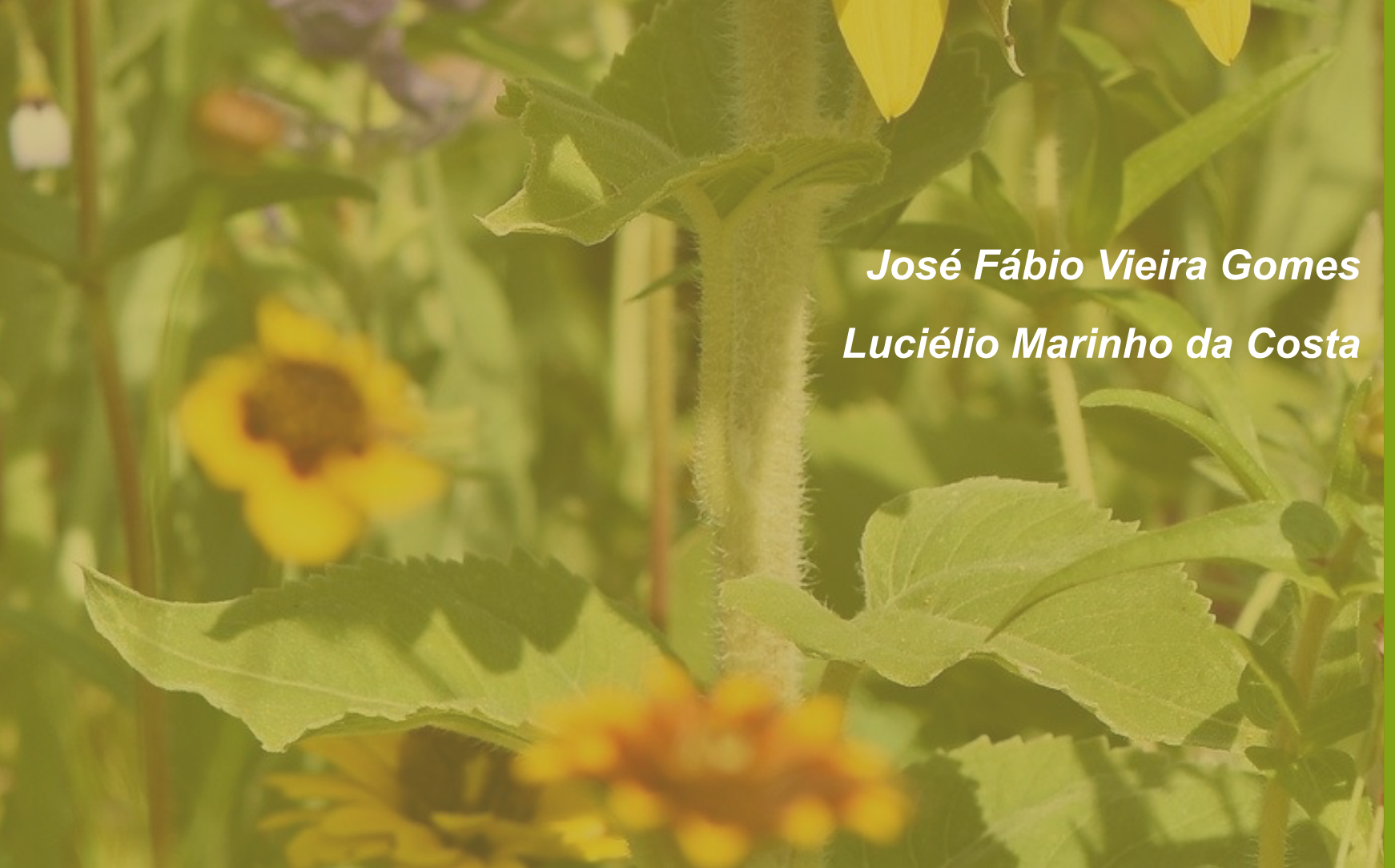
SABERES E EXPERIÊNCIAS DE PRÁTICAS PEDAGÓGICAS NO CONTEXTO EDUCACIONAL

\section{INTRODUÇÃO}

Essa pesquisa tem como objeto de estudo a prática docente na multisseriação e parte da seguinte problematização: como acontece a prática docente na multissérie da escola Antônio Sinésio dos Santos? Para respondermos, traçamos como objetivo geral analisar a prática docente na multisseriação no contexto da Escola Antônio Sinésio dos Santos, lócus de investigação. Os objetivos específicos do nosso trabalho foram: identificar a compreensão dos docentes da escola sobre a multisseriação; compreender o processo formativo dos docentes e sua relação com a prática docente; verificar a prática docente na multissérie, considerando as condições estruturais da realidade do campo.

O estudo trata de uma pesquisa de campo realizada na Escola Antônio Sinésio dos Santos, no Sítio Itamatay, localizado no município de Pirpirituba - PB. A pesquisa busca contribuir com discussões já existentes no tocante à prática docente na multissérie na escola do campo já citada, bem como fomentar reflexões que possam ressignificar a prática docente no contexto dessa configuração curricular na escola, através das análises da fala dos professores.

Metodologicamente, trata-se de uma pesquisa de campo Gil (1999), situa-se na abordagem qualitativa Flick (2009), com finalidade exploratória Gil (2002). Consideramos a pesquisa do tipo estudo de caso (Fonseca, 2002), Como procedimento de coleta de dados, tivemos, por razões da pandemia do Covid-19, assim como decretos (estadual e municipal), suspender as entrevistas semiestruturadas, como mais pertinente em uma pesquisa de abordagem qualitativa, substituindo-as por questionários. Como técnica de análise dos dados, utilizamos a análise de conteúdos conforme (BARDIN, 2004).

Nesse cenário, utilizamos algumas categorias necessárias em nossa pesquisa. Para a bem compreensão das categorias de análise dialogamos com alguns teóricos como Molina (2003), Caldart (2004) na construção de educação do/no campo; Hage $(2006,2008,2009,2010)$ e Parente (2014), para a com- 
preensão do conceito de multisseriação e, por fim, Silva (2009), Veiga (1989) para a compreensão de prática docente.

Nesse sentindo, podemos afirmar que a prática docente na configuração multisseriada da referida escola, acontece na lógica urbanocêntrica; os docentes teoricamente conhecem o conceito, bem como a funcionalidade multissérie, no entanto, suas práticas são em uma perspectiva lógica seriada; e suas formações acontecem sem considerar a especificidade do campo, como também a realidade e seus contextos.

\section{EDUCAÇÃO DO CAMPO: A MULTISSÉRIE E SUA PRÁTICA DOCENTE}

Antes de começarmos a teorizar sobre a prática docente na multisseriação na escola do campo, vamos traçar, nessa seção, um breve histórico da educação do campo no Brasil. Por isso, precisamos definir os sujeitos que dela fazem parte: são todos aqueles que vivem no campo e que têm uma cultura campesina a ser respeitada. Partimos dos rompimentos que aconteceram durante essa trajetória, como também a conceituação - de educação rural e educação do campo - que possibilitou mudanças favoráveis para os sujeitos do campo, ao longo desse percurso.

Historicamente, o conceito de rural estava vinculado ao homem do campo como atrasado, com uma educação sem qualidade. A educação rural é vista como algo precário, baixo e inferior perante a cidade; a sua conceituação está ligada à lógica do capitalismo, a fim de atender os interesses do mercado. Contudo, esse conceito permanece, e está em disputa com a educação do campo que é um projeto que reivindica substituir a educação rural.

Para Molina (2003, p. 109), "a ruptura com o paradigma da educação rural está no movimento por uma educação do campo por que recusa a visão de uma educação precária, atrasada com pouca qualidade e poucos recursos, tendo como pano de fundo um espaço rural visto como inferior e arcaico". Portanto, o conceito 
de educação do campo é um rompimento com o paradigma rural, justamente por suas precariedades e visão retardada do povo do campo, surgindo um novo conceito que possibilitou caminhos de avanços do homem do campo em sua vida.

Conforme Barros e Lihtnov (2016), em um encontro do Movimento dos Trabalhadores Rurais Sem Terra:

[...] em 1987, é criada a setorial de educação do Movimento dos TrabaIhadores Rurais Sem Terra. Deste encontro afloram algumas propostas para a temática da educação rural, sendo a principal delas melhorar a qualidade do ensino a partir da apreciação das necessidades existentes no campo. Este será o marco de transição entre a Educação Rural e a Educação do Campo (BARROS; LIHTNOV, 2016, p. 32).

Nesse sentido, a busca por melhoria do ensino no campo passou pela ruptura da concepção de educação rural, que tem por base de sustentação o capitalismo agrário com forte influência no agronegócio, tendo uma visão de território como um espaço de produção e lucro, totalmente contrário à concepção de educação do campo.

Por conseguinte, os debates relacionados à educação do campo tiveram uma intensificação a partir de julho de 1997, com o Encontro de Educadores e Educadoras da Reforma Agrária (IENERA) no Campus da Universidade de Brasília (UnB), sendo que o Movimento dos Trabalhadores Rurais Sem Terra (MST) que promoveu esse encontro: "juntamente com o Fundo das Nações Unidas para Infância - UNICEF, a Organização das Nações Unidas para Educação, Ciência e Cultura - UNESCO e a Conferência Nacional dos Bispos do Brasil - CNBB" (SANTOS, 2009, p. 39).

Nesse sentido, surgiram outros encontros que foram necessários para a transformação desse paradigma de rural para o campo, a exemplo da I Conferência Nacional Por Uma Educação Básica do Campo, realizada em Luziânia-GO, de 27 a 31 de julho de 1998. Falando a respeito dessa Conferência sobre educação do campo como importante para a luta pelas escolas do campo, Caldart destaca: 
SABERES E EXPERIÊNCIAS DE PRATICAS PEDAGÓGICAS NO CONTEXTO EDUCACIONAL

[...] Precisamos aprender a potencializar os movimentos das diversas experiências e transformá-los em um "movimento consciente de construção das escolas do campo" como escolas que ajudem neste processo mais amplo de humanização e de reafirmação dos povos do campo como sujeitos de seu próprio destino, de sua própria história (CALDART, 2004, p. 89-90).

Com isso, tivemos ainda um importante marco na história da educação do campo que foi a aprovação das Diretrizes Operacionais para a Educação Básica nas Escolas do Campo por meio da Resolução do Conselho Nacional de Educação $n^{\circ}$ 1/2002, de 3 de abril de 2002. Essa resolução estabeleceu princípios concernentes aos sujeitos do campo, como identidade, saberes, cultura e memória coletiva. Além disso, adequou o projeto institucional das escolas do campo às diretrizes nacionais do ensino infantil, fundamental, médio, jovens e adultos, especial, indígena, bem como a educação profissional de nível técnico e formação de docentes de nível médio (BRASIL, 2002).

Portanto, com essas conquistas e avanços para a educação do campo, caminhos foram traçados, como o Seminário Nacional, realizado em Brasília, de 26 a 29 de novembro de 2002, que estabeleceu, de fato, a mudança de educação rural para educação do campo, uma vez que serviu para impulsionar debates da II Conferência Nacional por Uma Educação do Campo, que foi realizado em Luziânia - GO, nos dias 2 a 6 de agosto de 2004. Esse rompimento aconteceu conforme nos falam os autores:

Utilizar-se-á campo, e não mais a usual, meio rural, com o objetivo de incluir no processo da conferência uma reflexão sobre o sentido atual do trabalho camponês e das lutas sociais e culturais dos grupos que hoje tentam garantir a sobrevivência desse trabalho [...] (KOLLING; NERY; MOLINA, 1999, p. 26).

Migrando de rural para o campo, esse novo conceito de educação do campo abriu também horizontes, possibilitando identificar quem são esses sujeitos do campo, não somente como aqueles que trabalham com a agricultura, mas também novos povos que sobrevivem nesse espaço e desempenham outras atividades além da agricultura, com uma diversidade do campo. Os sujeitos que a compõe são pequenos agricultores, quilombolas, indígenas, pescadores, camponeses, 
SABERES E EXPERIÊNCIAS DE PRATICAS PEDAGÓGICAS NO CONTEXTO EDUCACIONAL

assentados, reassentados, ribeirinhos, povos das florestas, caipiras, lavradores, roceiros, sem-terra, agregados, caboclos, meeiros, boias frias. A Resolução $n^{\circ}$ 2 de 2008 no parecer do conselho nacional de educação/câmara de educação básica (CNE/CEB), estabelece no Art. $1^{\circ}$

[...] destina-se ao atendimento às populações rurais em suas mais variadas formas de produção da vida - agricultores familiares, extrativistas, pescadores artesanais, ribeirinhos, assentados e acampados da Reforma Agrária, quilombolas, caiçaras, indígenas e outros. [...] (BRASIL, 2008, p. 1).

Essa Resolução, que foi fruto da luta dos movimentos sociais do campo e das organizações surgidas anteriormente, define os sujeitos que pertencem ao campo, que sobrevivem e vivem no campo, e firma um parecer que orienta e garante uma normatividade que favorece os sujeitos do campo. Sendo assim, a educação do campo é gestada pelo sujeito do campo e com os sujeitos do campo, contrariando o projeto da educação rural que é pensado para e não com o homem camponês, mas algo que já vem pronto, preparado, projetando caminhos diferentes ao campesinato. Com a II Conferência, reforçando o que foi discutido na I Conferência, ambas acorridas em Luziânia-GO, buscou-se, cada vez mais, o reconhecimento da especificidade e de suas formas de viver no campo.

Portanto, a educação do campo, comprometida com as lutas dos sujeitos do campo, agora precisa pensar um modelo de escola do campo que leve em consideração as identidades próprias desses sujeitos, de modo a romper com a racionalização típica do sistema educacional urbanocêntrico seriado, tomado como modelo, e assumir as características próprias de escola campesina, que tem função social de emancipar os sujeitos do campo.

Nesse sentido, Hage (2021) percebe que a escola urbanocêntrica ao primar o sistema seriado de ensino como modelo "regular" nas escolas do campo, desconsidera, e desqualifica outras formas de organização, efetivando a exclusão de experiências educativas outras, como a multisseriação. Com isso, a multisseriação é rotulada, adjetivada, e sendo usada para reforçar o modelo seriado, e o fechamento das escolas do campo (PARENTE, 2014). 
SABERES E EXPERIÊNCIAS DE PRATICAS PEDAGÓGICAS NO CONTEXTO EDUCACIONAL

Para Santos, as turmas multisseriadas são:

Uma forma de organização escolar caracterizada pela oferta do ensino a um grupo de estudantes constituído de vários níveis de aprendizagem (ano, série, grau, ciclo, etc.) e diferentes idades, reunidos em um mesmo espaço (uma sala de aula), geralmente sob responsabilidade de apenas uma professora ou professor (SANTOS, 2015, p. 87).

Considerando que esse fenômeno das turmas multisseriadas tem sua gênese na escola rural, embora estejam presentes também no meio urbano; nas escolas que com essa forma de organização de ensino, os professores, geralmente, enfrentam essa realidade nas escolas do campo em sua prática docente: lecionam em uma sala multissérie com muitas séries ao mesmo tempo, além do mais, exercem outras funções que não são de sua competência.

Nesse contexto de esquecimento, a multisseriação revela muitos descasos presente nas escolas do campo, entre eles, os descasos relativos à prática docente, bem como às condições de trabalho. Parente diz que:

A multisseriação é uma prática que incomoda. E vem incomodando cada vez mais porque é a partir dela que são expostos muitos dos históricos problemas educacionais: escassa infraestrutura material, pedagógica, administrativa e de recursos humanos; condições precárias de trabalho e de formação docente (PARENTE, 2014, p. 58-59).

A prática docente nessa configuração de ensino, torna-se desafiador, e um desafio. Segundo Fagundes e Martini (2013), sobre essa realidade da docência na multisseriação nas escolas do campo, há limitações que os professores dessas escolas enfrentam em suas práticas, como o acúmulo de cargos, sendo que além de professor de uma classe com diferentes séries, assume funções de merendeiro, faxineiro, diretor, secretário, etc.

Conforme Hage (2006, p. 309), uma das dificuldades docentes na sala multisseriada consiste no fato de que "os professores enfrentam dificuldade em realizar o planejamento nas escolas multisseriadas por que trabalham com muitas séries ao mesmo tempo, envolvendo estudante de diversas faixas etárias, interesses e níveis de aprendizagem [...]" (HAGE, 2006, p. 309, grifo nosso). 
SABERES E EXPERIÊNCIAS DE PRÁTICAS PEDAGÓGICAS NO CONTEXTO EDUCACIONAL

Nesse caminho, outro entrave é a formação (inicial e continuada) dos professores das classes multisseriadas, fator a ser considerado, pois muitos possuem formações deficitárias, atuando em áreas distintas da que foram formados. Há, também, casos em que a inexistência de formações agrava ainda mais tal situação. Na formação continuada, os professores e pais e toda comunidade se sentem sem apoio das secretarias, que deveriam dar um suporte formativo e um acompanhamento pedagógico para os docentes do campo; no entanto, percebe-se o quanto não se tem assistência por parte dos sistemas, deixando os docentes do campo privados de orientação, a sós (HAGE, 2008).

Concernente ao processo formativo, temos o currículo descontextualizado distante do campo, sem considerar a cultura dos sujeitos. Diante disso, a escola do campo precisa de um currículo que esteja voltado para sua realidade. Com um currículo centralizado oriundo da cidade, a cultura campesina fica desprovida de direitos, de uma educação que trabalhe com suas identidades. Nesse contexto, Hage (2008, p. 10, grifo nosso) diz que: "as escolas multisseriadas têm assumido um currículo deslocado das culturas da população do campo, situação que precisa ser superada caso se pretenda enfrentar o fracasso escolar e afirmar as identidades culturais das populações do campo".

Outro aspecto que dificulta a prática docente das classes multisseriadas refere-se aos materiais didáticos que os professores do campo utilizam em suas aulas, os quais não são preparados para a realidade campesina e nem para a organização multisseriada. Essa ação vai refletir, também, em uma prática docente igual à organização seriada, restando: "seguir as indicações do livro didático, sem atentar com clareza para as implicações curriculares dessa atitude, uma vez que esses manuais didáticos têm imposto a definição de um currículo deslocado da realidade [...]" (HAGE, 2008, p. 03).

Além disso, uma preocupação que desestimula o exercício docente são as estruturas físicas em estados de precariedade. Muitas delas não têm as mínimas possibilidades para funcionar. Os móveis escolares, como quadros e carteiras, 
SABERES E EXPERIÊNCIAS DE PRATICAS PEDAGÓGICAS NO CONTEXTO EDUCACIONAL

geralmente, se encontram danificados, e, ainda, muitas das escolas do campo com essa organização de ensino não têm prédio próprio, passando a funcionar em casas de professores, igrejas e barracões de festas ou prédios alugados.

Conforme Hage (2009, p. 27), “[...] muitas escolas constituem-se em um único espaço físico e funcionam em salões paroquiais, centros comunitários, varandas de residências, não possuindo área para cozinha, merenda, lazer, biblioteca, banheiro, etc.". Com isso, "o processo de ensino-aprendizagem é prejudicado pela precariedade da estrutura física das escolas multisseriadas [...]" (HAGE, 2009, p. 27).

Elaboramos, a partir do questionário aplicado com os docentes, um quadro de análise caracterizando o perfil do corpo docente da escola, que recebeu pseudônimos, sendo denominado como Professor (a): (A), (B), (C).

QUADRO 01 - Perfil dos professores

\begin{tabular}{|c|c|}
\hline SUJEITO & PERFIL DOS RESPONDENTES \\
\hline Professora A & $\begin{array}{r}\text { Série/Ano que leciona: Educação Infantil I e II, e } 1^{\circ} \text { ano } \\
\text { Formação: Não respondeu à questão }\end{array}$ \\
Tempo de atuação em sala de aula: 18 anos \\
Mrora na Comunidade: Não
\end{tabular}

Fonte: Elaborado pelos autores. 


\section{DIÁLOGOS CRUZADOS: A FALA DOS PROFESSORES}

Nesta seção, apresentamos e analisamos os dados da pesquisa empírica a partir das falas dos docentes coletadas por meio dos questionários sobre as categorias: conceituação sobre multisseriação, processo formativo considerando a especificidade do campo, bem como, a prática docente na realidade da escola.

\subsection{Conceito sobre multissérie no campo: invisibilidade e esperanças futuras}

Embora a multisseriação seja tão frequente nas escolas do campo, é bem menor a sua quantidade na cidade, sendo que a sua real significação é desconhecida por muitos profissionais da educação, gestores, secretários. A maioria conhece na prática, poucos por definição. O fato é que a multisseriação, conforme Teixeira e Lima (2011), é uma realidade que está no campo, onde uma turma com um único professor leciona para várias séries no mesmo espaço. Portanto, achamos pertinente o professor conhecer o conceito de multissérie, para dar fundamento e direção à sua prática docente.

Nas respostas aos questionários aplicados nessa pesquisa com os professores sobre a concepção de multisseriação, como resposta tivemos:

Sala multisseriada é onde se pode agrupar duas ou mais série para se trabalhar de formar contextualizada os diferentes níveis de aprendizagem, apresentando um tema (projeto ou conteúdo) para todos com objetivos e atividades diferenciadas de acordo com as capacidades e níveis das crianças (Professora A, 2020).

É a forma de ensino onde o professor trabalha com sua turma com discentes de diferentes séries. [...] trabalhar com a turma heterogênea no que diz respeito a séries diferentes do ensino fundamental e infantil (Professora B, 2020).

A multisseriação é uma mistura de várias séries em uma mesma sala de aula, isso não quer dizer que em uma sala normal não haja uma multisseriação (Professor C, 2020).

Nas respostas, observa-se que os professores, pelas suas respectivas respostas, têm clareza sobre a multissérie. A prática vivenciada no cotidiano permite 
SABERES E EXPERIÊNCIAS DE PRATICAS PEDAGÓGICAS NO CONTEXTO EDUCACIONAL

falar com mais propriedade. Para a professora A, ao falar sobre o que entende por multissérie, colocou uma palavra diferente em relação aos outros, e que chamou atenção, que na sala multissérie é preciso: "trabalhar de forma contextualizada os diferentes níveis de aprendizagem". Destacamos que essa fala é importante, pois é necessário que o currículo da escola do campo possa ser contextualizado para contemplar a configuração multissérie, bem como as identidades dos sujeitos, a fim de ter "[...] intenções educativas" que "[...] contribuem para a construção das identidades de nossos/as estudantes" (MOREIRA; CANDAU, 2007, p. 18).

Para a professora $\mathrm{B}$, um elemento importante presente nas salas multisseriadas é a presença da heterogeneidade e a diversidade de níveis de aprendizagem, consideradas como uma gama de culturas de cada sujeito em suas vivências e que cada um carrega em si conhecimentos de mundo. O professor $C$, falando a respeito da multissérie, nos diz que é uma mistura de várias séries na mesma sala, porém, em uma sala "normal", ou seja, seriada, pode ter multisseriação; com essa fala, o docente, de uma forma implícita, mostra a heterogeneidade das turmas seriadas regida pelo contexto "homogêneo". Para Freitas (2010, p. 394), a heterogeneidade, sendo uma característica das classes multisseriadas, "[...] ganha força, quando o(a) professor(a) compreende-a como fator importante para as interações que devem ocorrer nas classes multisseriadas".

Nesse sentido, os professores conhecem a definição dessa organização de ensino, precisando que tudo isso seja agregado para uma prática docente, considerando o contexto heterogêneo, metodológico e organizacional. Percebemos que o tanto que os professores conhecem sobre a multisseriação é fruto de experiências da prática em sala de aula buscando metodologias, pois, muitas vezes, não recebem suporte da coordenação pedagógica, ficando em uma situação que "[...] aponta-se enquanto retratos da exclusão ao qual estão submetidos os campesinos" (TEIXEIRA; LIMA, 2011, p. 1). 
SABERES E EXPERIÊNCIAS DE PRÁTICAS PEDAGÓGICAS NO CONTEXTO EDUCACIONAL

\subsection{Docência e processo formativo na multissérie: uma questão em aberto}

Com a descrição no quadro um (1) percebemos que a formação inicial dos professores não é condizente para lecionar no ensino fundamental I, bem como na especificidade do Campo, e para Ihe dar com a multisseriação. Nesse sentido, passamos agora para a formação continuada, considerando o conjunto específico da realidade do campo da escola pesquisada. As respostas foram as seguintes:

Sim. As escolas participam anualmente de formações na universidade, em Bananeiras (Professora A, 2020).

Sim, sempre acontece (Professora B, 2020).

Sim (Professor C, 2020).

Conforme a professora $A$, as formações são realizadas e acontecem na universidade em Bananeiras, mas, apenas anualmente. Para a professora B, as formações acontecem, dando ênfase no "sempre", referindo que as formações não deixam de acontecer; na fala do professor $\mathrm{C}$, encontramos a mesma resposta dos outros, confirmando a coerência entre as três falas, pois o mesmo respondeu que "sim". Nesse sentido, podemos inferir que na referida escola a formação continuada é realizada, pois, nas falas dos professores, todos são unânimes em suas respostas. No entanto, segundo a fala da professora $A$, é realizada "anualmente", já na da professora B, acontece "sempre", o que nos leva a entender que são realizadas, porém não periodicamente. Dessa forma, a periocidade é necessária, porém se torna importante quando a temática da formação leva em consideração a questão da multisseriação e a educação do campo.

Para Hage (2008), percebemos que a falta de formação dos docentes do campo para as turmas multisseriadas é motivo de reclamações por parte dos pais e familiares, os quais "[...] afirmam ser estas discriminadas em relação às escolas da cidade, que têm prioridade em relação ao acompanhamento pedagógico e formação dos docentes" (HAGE, 2008, p. 03, grifo nosso). Por consequência, o desprezo com que os professores são tratados em detrimento dos da cidade, em matéria de formação continuada, é preocupante. Por não serem realizadas periodicamente, e em sua especificidade acabam deixando lacunas. De curta du- 
SABERES E EXPERIÊNCIAS DE PRATICAS PEDAGÓGICAS NO CONTEXTO EDUCACIONAL

ração, tal formação não é ideal para uma formação de qualidade, que exige uma preparação que se adeque ao caminho formativo dos docentes (NÓVOA, 1992).

\subsection{A prática docente na multissérie: a fala dos docentes a partir da realidade campesina}

A prática docente, para Silva (2009), é uma dimensão da prática pedagógica que configura um elemento fundamental no trabalho do professor. Sendo um polo da prática pedagógica, a prática docente não precisa ser algo pragmático, utilitarista, mas, reflexiva e capaz de ser crítica. Está imbuída de intencionalidades políticas, econômicas, educacionais, bem como sociais (VEIGA, 1989). Portanto, se entende a prática docente: "[...] por profissional do ensino, cuja ação, seja ela sistemática ou assistemática, dá-se sempre no ambiente escolar" (BANDEIRA; IBIAPINA, 2014, p. 113).

Nesse sentido, no âmbito das classes multisseriadas, a ação docente precisa tecer um olhar crítico que possibilite, em sua prática na multissérie, um trabaIho especificado para essa configuração, rompendo com a lógica seriada imposta como modelo que deve ser seguido. Com base nessas premissas, a fala dos professores, no tocante às suas atuações na sala multisseriadas, foram:

Procuramos fazer da melhor forma, para que o aprendizado aconteça, é um desafio constante (Professora A, 2020).

Organizo as turmas por série, ou seja, divido assim, $1^{\circ}$ ano $/ 2^{\circ} a n o / 3^{\circ} a n o$, divido a sala em parte (Professora B, 2020).

Isso é complicado, a gente tenta nivelar os alunos de acordo com sua capacidade. (Professor C, 2020).

Ao analisarmos a fala do professor $\mathrm{C}$, percebemos que ele procura identificar os níveis de aprendizagem de cada sujeito, algo que da parte do docente é um anseio que procura melhores possibilidades para facilitar o ensino-aprendizagem; no entanto, tal anseio é feito em uma perspectiva da escola seriada. Ao passo que o professor percebe que é complicado fazer tal ação, podemos perceber que a lógica seriada está presente na sua fala, pois a lógica seriada é o modelo que se tem e sair desse modelo é de uma complexidade, por isso, é 
preciso: "[...] transgredir à "precarização do modelo seriado urbano", que constitui o traço identitário dominante das escolas multisseriadas (HAGE, 2010, p. 25)

A fala da professora B endossa o que foi analisado anteriormente, pois, ao organizar a sala por séries, reproduz o modelo seriado; o que acontece é que a sala é multisseriada, mas todas as ações pedagógicas são dentro de um paradigma seriado, querendo homogeneizar a turma, negando sua diversidade. Analisando a professora A, se encontra em sua fala, a preocupação com a aprendizagem dos sujeitos, bem como as dificuldades nesse processo. Isso fica evidenciado quando fala que "é um desafio constante" ao referir-se à aprendizagem nessa organização de ensino.

Os três docentes, ao responderem, trazem em suas respostas uma impregnação das escolas organizadas em seriação, fator que pode ter acontecido pela formação inicial e continuada, pois a realidade multisseriada é invisibilizada nessas formações, tendo como consequência a prática docente orientada na perspectiva seriada. Santos (2015, p. 322) diz que tais práticas são: “[...] ancoradas no paradigma da seriação, que vai ser tomado como orientador da organização didático-pedagógica em sua sala de aula [...].

\section{CONSIDERAÇÕES FINAIS}

Esta pesquisa buscou problematizar a prática docente na multissérie na Escola do Campo Antônio Sinésio dos Santos, localizada no município de Pirpirituba-PB, considerando as realidades do campo e seus entraves. Nosso propósito consistiu em auxiliar na reflexão dos docentes, contribuindo para fortalecer suas práticas pedagógicas com essa configuração de ensino na escola.

Ao analisarmos os questionários aplicados com os professores, identificamos que, apesar de os docentes terem uma conceituação sobre multissérie, a reprodução da seriação é seguida como modelo padrão estabelecido na cidade, negando a especificidade da multissérie em seu fazer pedagógico. Compreendemos que os professores carecem de formação inicial voltada para a especificida- 
de do campo, sendo que a formação continuada é deficitária por não acontecer periodicamente. Além disso, verificamos que os docentes sentem dificuldades para lecionar nas turmas multissérie, bem como para organizar o espaço, uma vez que o modelo de escola segue uma lógica urbanocêntrica seriada.

Afirmamos que a prática docente na organização multisseriada da escola Antônio Sinésio dos Santos acontece entre muitos entraves e que os professores, em seu fazer docente, reproduzem o modelo urbanocêntrico de organização seriada. Apesar de seus esforços para um processo de ensino-aprendizagem eficaz, a multissérie é vista como negativa e é negligenciada por parte dos órgãos públicos competentes.

Portanto, concluímos esta pesquisa afirmando que a prática docente na organização multissérie na referida escola acontece no ângulo da lógica urbanocêntrica, com formações sem direcionamentos para as especificidades e seus contextos da realidade campesina, necessitando que os órgãos competentes viabilizem esforços no sentido de olhar para multissérie como organização de ensino, tecendo outros olhares para além da lógica seriada.

\section{REFERENCIAS}

BANDEIRA, Hilda Maria Martins; IBIAPINA, Ivana Maria Lopes de Melo. Prática educativa: entre o essencialismo e a práxis. Revista da FAEEBA. Educação e Contemporaneidade, Salvador, v. 23, n. 42, p. 107-117, jul./dez. 2014. Disponível em: https://www.revistas.uneb.br/index.php/faeeba/article/download/1031/711. Acesso em: 03 ago. 2020.

BARDIN, Laurence. Análise de conteúdo. Lisboa: Edições 70, 2004.

BARROS, Lânderson Antória; LIHTNOV, Dione Dutra. Reflexões sobre a Educação Rural e do Campo: As leis, diretrizes e bases do ensino no e do campo no Brasil. Geographia Meridionalis, Revista eletrônica do Programa de Pós-Graduação em Geografia da Universidade Federal de Pelotas, v. 02, n. 01, p. 20-37, abr./mai. 2016. Disponível em: http://periodicos.ufpel.edu.br/ojs2/index. php/Geographis/index. Acesso em: 03 ago. 2020. 
BRASIL. Conselho Nacional de Educação. Resolução CNE/CEB No 1, de 3 de abril de 2002. Diretrizes Operacionais para a Educação Básica nas Escolas do Campo. Disponível em: http://pronacampo.mec.gov.br/images/pdf/mn_resolucao_\%201_de_3_de_abril_de_2002.pdf. Acesso em: 20 ago. 2020.

BRASIL. Conselho Nacional De Educação. Resolução Complementar CNE/ CEB № 2, de 28 de abril de 2008. Estabelece Diretrizes complementares, normas e princípios para o desenvolvimento de políticas públicas de atendimento à Educação do Campo. Disponível em: http://portal.mec.gov.br/arquivos/pdf/resolucao_2.pdf. Acesso em: 18 ago. 2020.

CALDART, Roseli Nunes. Pedagogia do movimento sem-terra. 3. ed São Paulo: Expressão Popular, 2004.

FAGUNDES, José; MARTINI, Adair Cesar. Políticas Educacionais: da escola multisseriada à escola nucleada. Olhar de Professor, Ponta Grossa, v. 6, n. 1, p. 99-118, 2013. Disponível em: https://www.redalyc.org/pdf/684/68460108.pdf. Acesso em: 20 ago. 2020.

FLICK, Uwe. Desenho da pesquisa qualitativa. Porto Alegre: Artmed, 2009.

FONSECA, João José Saraiva. Metodologia da pesquisa científica. Fortaleza: UEC, 2002. Apostila.

FREITAS, Maria Natalina Mendes Freitas. Heterogeneidade: fios e desafios da escola multisseriada da Ilha de Urubuoca. In: ANTUNES-ROCHA, Maria Isabel; HAGE, Salomão Mufarrej. (rgs.). Escola de Direito: reinventando a escola multisseriada. Belo Horizonte: Autêntica, 2010. p. 387-395.

GIL, Antônio Carlos. Métodos e técnicas de pesquisa social. São Paulo: Atlas, 1999.

GIL, A.C. Como elaborar projetos de pesquisas. $4^{\circ}$ Ed. São Paulo: Atlas S/A, 2002.

HAGE, Salomão Mufarrej. Movimentos sociais do campo e afirmação do direito à educação: pautando o debate sobre as escolas multisseriadas na Amazônia paraense. Revista Brasileirade Estudos Pedagógicos, Brasília, v. 87, n. 217, p. 302-312, set./dez. 2006. 
HAGE, Salomão Mufarrej. A Multissérie em pauta: para transgredir o Paradigma Seriado nas Escolas do Campo. São Paulo: Texto Multissérie, 2008.

HAGE, Salomão Mufarrej. A multissérie em pauta: para transgredir o paradigma seriado nas escolas do campo. In: ENCONTRO DE PROFISSIONAIS DE CLASSES MULTISSERIADAS DAS ESCOLAS DO CAMPO DA BAHIA, 1., 2009, Salvador. Anais [...]. Salvador, 2009.

HAGE, Salomão Mufarrej et al. Retratos de realidade das escolas do campo: multissérie, precarização, diversidade e perspectivas. In: ANTUNES-ROCHA, Maria Isabel; HAGE, Salomão Mufarrej. (Orgs.). Escola de Direito: reinventando a escola multisseriada. Belo Horizonte: Autêntica, 2010. p. 25-33.

KOLLING, Edgar Jorge; NERY, Israel; MOLINA, Monica Castagna. Por uma educação básica do campo (memória). Brasília: Articulação Nacional por uma Educação do Campo, 1999.

MOLINA, Mônica Castagna. A contribuição do PRONERA na construção de políticas públicas de educação do campo e desenvolvimento sustentável. Tese (Doutorado em Educação) - Universidade de São Paulo, São Paulo, 2003.

MOREIRA, Antônio Flávio Barbosa; CANDAU, Vera Maria. Indagações sobre currículo: Currículo, Conhecimento e Cultura. Brasília: Ministério da Educação, Secretaria de Educação Básica, 2007. Disponível em: http://portal.mec.gov.br/ seb/arquivos/pdf/Ensfund/indag3.pdf. Acesso em: 24 ago. 2020.

NÓVOA, António. Formação de professores e profissão docente. In: NOVOA, António. (org.). Os professores e sua formação. Lisboa: Dom Quixote, 1992.

PARENTE, Cláudia da Mota Darós. Escolas multisseriadas: a experiência internacional e reflexões para o caso brasileiro. Ensaio: avaliação e políticas públicas em educação, v. 22, n. 82, p. 57-88, 2014. Disponível em: http://www.redalyc.org/ articulo.oa?id=399534053004. Acesso em: 20 ago. 2020.

SANTOS, Clarice A. dos. Educação do Campo e Políticas Públicas no Brasil: o protagonismo dos movimentos sociais do campo na instituição de políticas públicas e a Licenciatura em Educação do Campo na UnB. 2009. 143 f. Dissertação (Mestrado em Educação) - Universidade de Brasília, Faculdade de Educação, Brasília, 2009. 
SANTOS, Fábio Josué Souza dos. Docência e memória: narrativas de professoras de escolas rurais multisseriadas. Tese (Doutorado em Educação e Contemporaneidade), 402 fls. Universidade do Estado da Bahia. Salvador/BA, 2015.

SILVA, Maria do Socorro. As práticas pedagógicas das escolas do campo: a escola na vida e a vida como escola. 2009. Tese (Doutorado em Educação) - Universidade Federal de Pernambuco, Recife/PE, 2009.

TEIXEIRA, Rosiane do Carmo; LIMA, Silvana Lucia da Silva. Classes multisseriadas: desafios e possibilidades para construções de um projeto de educação do campo. In: Entrelaçando - Revista Eletrônica de culturas e Educação, $n$. 2, p.1-16, set. 2011. Disponível em: https://www2.ufrb.edu.br/revistaentrelacando/component/phocadownload/category/85\%3Fdownload\%3D91+\&cd=1\&hl=ptBR\&ct=clnk\&gl=br. Acesso em: 04 ago. 2020.

VEIGA, Ilma Passos Alencastro. A prática pedagógica do professor de didática. Campinas, SP: Papirus, 1989. 

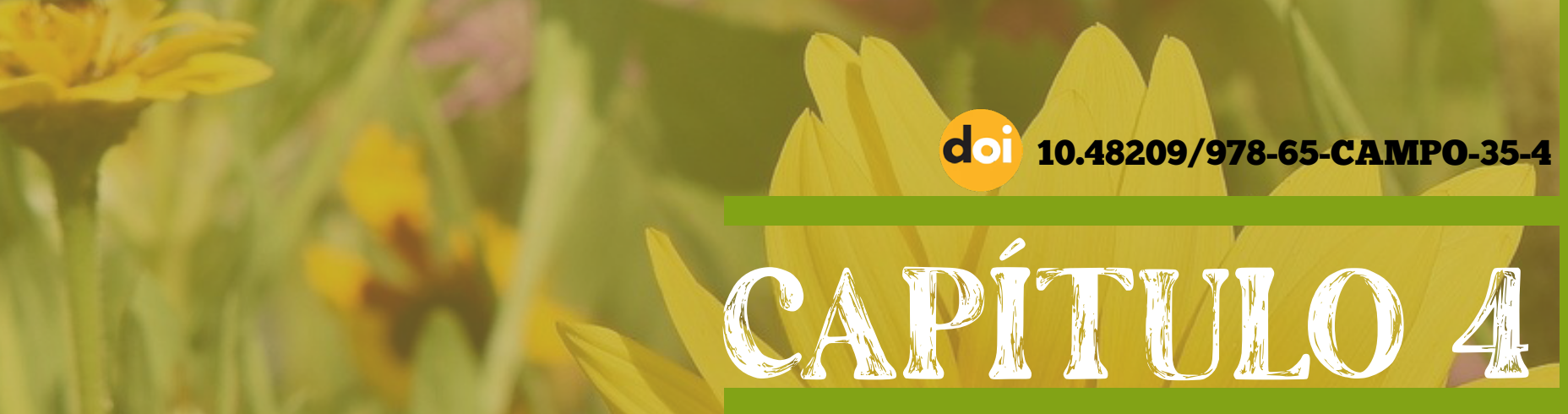

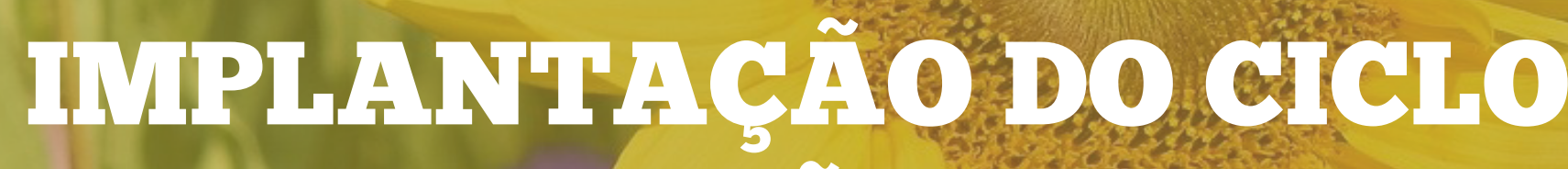
DE FORMACLOC TUMANA NA PDUCACSANO DIFANHL DA RSCOLA DO CAMPO
JOSE PERETRA DURVAT

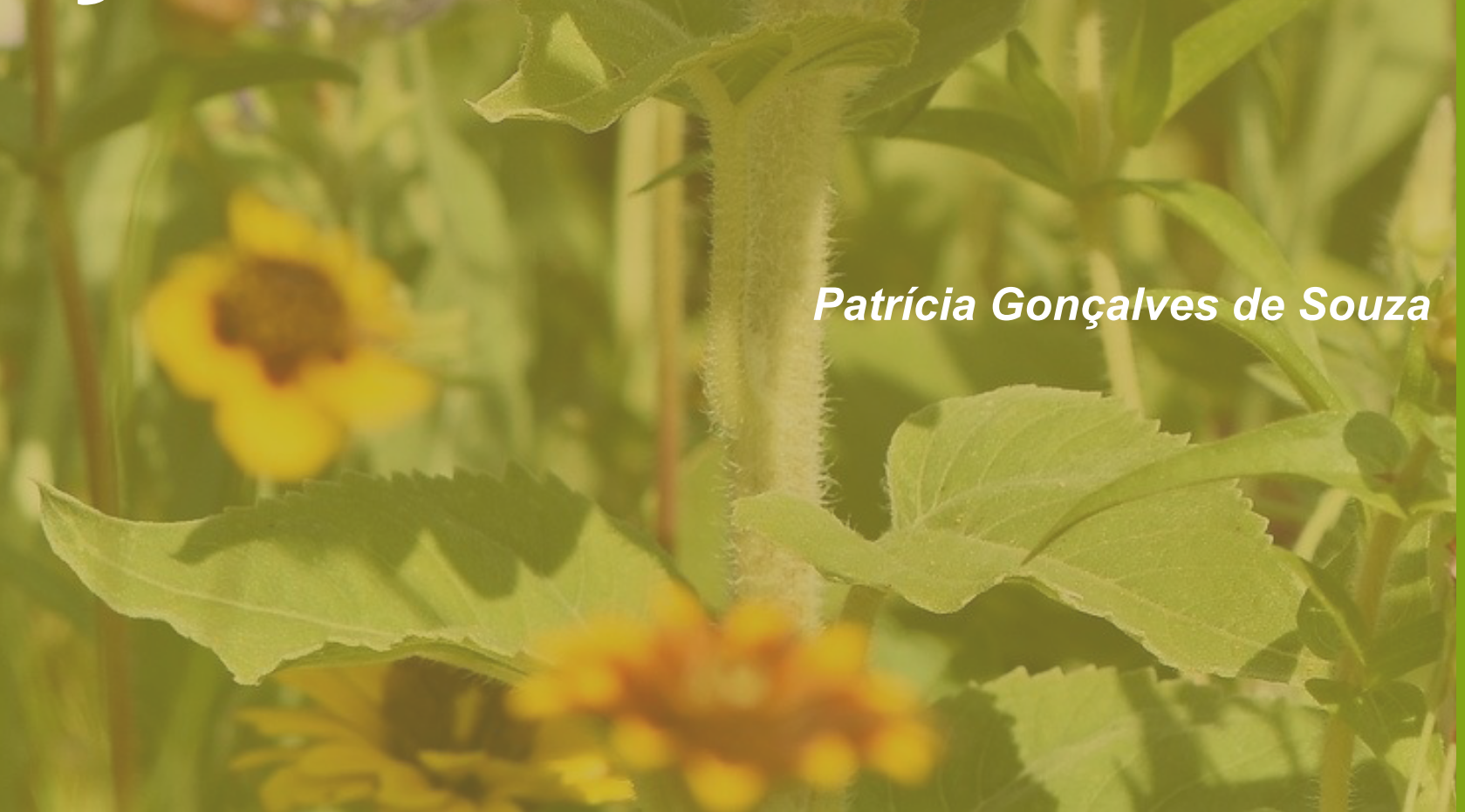


SABERES E EXPERIÊNCIAS DE PRÁTICAS PEDAGÓGICAS NO CONTEXTO EDUCACIONAL

\section{Resumo}

A referida pesquisa objetiva analisar o processo de implantação do Ciclo de Formação Humana - CFH, na educação infantil da escola Municipal José Pereira Durval, situada no povoado de Umbuzeiro na cidade de Irecê Bahia. O estudo busca compreender o Ciclo de Formação Humana, em seu conceito, o qual aponta como possibilidade para romper a lógica do ensino linear, passando a ser compreendido como articulador do dinâmico e complexo processo de desenvolvimento e de aprendizagem dos sujeitos. Referendado em alguns teóricos que discutem a temática em questão como: Krug (2006), Mainardes (2014), Miranda (2008), Pereira (2007), entre outros, que auxiliam na discussão da importância de dialogar a proposta. Nessa perspectiva, a pesquisa traz como questionamento: Como implantar a proposta de trabalho por ciclo de formação humana em uma classe multigrupo, de uma escola do campo? Para tanto, a metodologia utilizada foi à qualitativa, a partir da pesquisa bibliográfica, fazendo uso da pesquisa documental e observações participativas aos sujeitos envolvidos no processo, além da análise dos marcos legais que amparam as temáticas em debate.

Palavras chave: Ciclo de Formação Humana, aprendizagem, avaliação na escola-Ciclo de Formação Humana

\section{Abstract}

This research aims to analyze the implementation process of the Human Formation Cycle - CFH, in early childhood education at José Pereira Durval school, located in the village of Umbuzeiro in the city of Irecê Bahia. The study seeks to understand the Human Formation Cycle, in its concept, which points as a possibility to break the logic of linear teaching, starting to be understood as an articulator of the dynamic and complex process of development and learning of the subjects. Countersigned by some theorists who discuss the subject in question, such as: Krug (2006), Mainardes (2014), Miranda (2008), Pereira (2007), among others, who help in the discussion of the importance of dialoguing the proposal. In this perspective, the research raises the following questions: How to implement the work proposal per cycle of human formation in a multigroup class, from a rural school? Therefore, the methodology used was qualitative, based on bibliographic research, making use of documentary research and observations to the subjects involved in the process, in addition to the analysis of the legal frameworks that support the topics under debate.

Keywords: Human Formation Cycle, learning, evaluation at school Human Formation Cycle 
SABERES E EXPERIÊNCIAS DE PRÁTICAS PEDAGÓGICAS NO CONTEXTO EDUCACIONAL

\section{INTRODUÇÃ̃O}

Os ciclos de formação constituem uma nova concepção de escola, na medida em que encaram a aprendizagem como um direito da cidadania, propõe o agrupamento dos estudantes, onde às crianças e adolescentes são reunidos pelas suas fases de desenvolvimento humano. Krug (2006)

Assim, a pesquisa objetiva analisar o processo de implantação do Ciclo de Formação Humana - CFH, na educação infantil da escola José Pereira Durval, situada no povoado de Umbuzeiro na cidade de Irecê Bahia, buscando compreender o Ciclo, em seu conceito, o qual aponta como possibilidade para romper a lógica do ensino linear, passando a ser compreendido como articulador do dinâmico e complexo processo de desenvolvimento e de aprendizagem dos sujeitos

Para Miranda (2005), na escola de Ciclo de Formação Humana, o importante é o sujeito estar na escola, pois estará aprendendo algo, sendo este espaço fundamental para a "experiência da cidadania, da convivência e da formação dos valores sociais" e o desenvolvimento humano na sua integralidade.

Nessa perspectiva, fundamentado em alguns teóricos que discutem a temática como: Krug 2006, Mainardes (2014), Miranda (2008), Pereira (2007), entre outros, que auxiliam na discussão da importância de dialogar a proposta, a pesquisa traz como questionamento: Como implantar a proposta de trabalho por Ciclo de Formação Humana em uma classe multigrupo, de uma escola do campo?

Dessa maneira, a adesão ao Ciclo de Formação Humana muda a forma de compreender o educando nas suas fases da vida; a relação com o conhecimento, tornando-o protagonista da sua itinerancia formativa, valorização da cultura, da arte e da sabedoria camponesa.

Assim, a metodologia utilizada foi a qualitativa a partir da pesquisa bibliográfica, fazendo uso da pesquisa documental e observação participante, no qual pude contribuir com as ações que estavam sendo desenvolvidas (discretamen- 
te), e aos sujeitos envolvidos no processo, além da análise dos marcos legais que amparam as temáticas em debate.

\section{CONTEXTO HISTÓRICO DA EDUCAÇÃO DO CAMPO}

Cada passo da história da educação camponesa, desde o descobrimento do país, durante a colonização, depois a independência e os demais acontecimentos históricos, marcaram sua trajetória. Educação que esteve ligada às demandas agrícolas de cada época, conforme a necessidade e o processo de produção e de industrialização do país. O direito à educação para a população do campo sobreveio a todos aos poucos.

O processo histórico da educação do campo sempre esteve atrelado aos movimentos sociais e vem se desenvolvendo principalmente no interior do movimento sem-terra - MST, no entanto, outros movimentos como quilombolas,

indígenas, caiçaras, comunidade de pecadores, pequenos agricultores, entre outros, estão cada vez mais se integrando a luta pela educação em suas comunidades.

A Educação do Campo vem travando lutas e disputas para demarcar um território e que nessa condição encontra-se em permanente estágio de alerta, pois propõe uma educação que parte da realidade, que forja sujeitos capazes de compreender as relações estabelecidas na sociedade.

Essa modalidade de educação que surge a partir das reivindicações dos movimentos sociais na década de 1990 para contrapor-se às concepções de educação rural, possuía caráter mais assistencialista e não correspondia às necessidades formativas dos povos do campo. A legislação educacional trouxe avanços para essa discussão, principalmente, a partir da década de 1990, com a Lei de Diretrizes e Bases da Educação Nacional de 1996.

Entretanto, apesar dos avanços na legislação e nas políticas públicas, na prática, a escola para os povos do campo, como tem ocorrido há anos na história da educação brasileira, não contempla as necessidades específicas dos povos 
do campo. Isso reverberou nas condições formativas dos professores do campo e nas condições estruturais e organizacionais das escolas do campo.

Por muitos anos, o projeto de educação do campo, foi uma imitação do modelo urbano de escolarização, ou seja, um conjunto de saberes que não fazia correlação com a realidade do homem do campo, pois os padrões pedagógicos eram voltados à sociedade elitizada.

De fato, a classe dominante não tem interesse na transformação histórica da escola. Ao contrário, estando ela empenhada na preservação de seu domínio, apenas acionará mecanismos de adaptação que evitem a transformação. (LOMBARDI, 2008, p. 254)

A Educação do Campo busca olhar os sujeitos e considerar as diferenças de acúmulos de cada um/uma e nisso consiste perceber que o campo necessita de uma educação que seja pensada olhando para suas especificidades, bem como que o currículo urbano não dá conta de contemplar, tornando-se incapaz de enxergar esse espaço com suas características e funções específicas e nem por isso menos importante, fazendo dele um apêndice do urbano, como se só existisse produção de conhecimento em um determinado lugar que, nesse caso, é na cidade.

\section{CICLO DE FORMAÇÃO HUMANA}

O Ciclo de Formação Humana busca romper com a fragmentação dos conteúdos, oportunizando ao sujeito um tempo maior para sua aprendizagem, respeitando o desenvolvimento e, principalmente, o ser humano como um ser inacabado. Dessa forma, surge a necessidade de refletir sobre a concepção homem, sociedade, desenvolvimento e aprendizagem, como uma preocupação continua com o processo de aprendizagem.

No contexto da educação brasileira, o termo "ciclo" já aparecia na Reforma Francisco Campos (década de 1930) e na Reforma Capanema (Leis Orgânicas do Ensino - 1942/1946) e era utilizado para designar o agrupamento dos anos de estudo. Já o uso do termo "ciclo" como forma de designar políticas de não-re- 
provação - surgiu em 1984, com a implantação do Ciclo Básico de Alfabetização (CBA) na Rede Estadual de São Paulo. No entanto, a ideia de eliminar a reprovação nos anos iniciais não é recente. Desde o início do século passado (década de 1910), já existia o debate sobre a necessidade da criação de políticas de não-reprovação.

A organização do ensino em Ciclos de Formação Humana no Brasil iniciou na década de 80, quando vários Estados e Municípios reestruturaram o Ensino Fundamental, $1^{\mathrm{a}}$ e $2^{\mathrm{a}}$ séries em um ciclo de dois anos, que tinha como objetivo político reduzir os índices de evasão e reprovação nas séries iniciais. O princípio orientador dessas propostas era flexibilizar o tempo, possibilitando que o currículo fosse trabalhado num período maior, permitindo assim respeitar os diferentes ritmos de aprendizagem dos alunos.

Os Ciclos de Formação já foram experimentados em países como a Espanha, Bélgica, França entre outros (Miranda, 2009), no Brasil é legitimado pela Lei de Diretrizes e Base da Educação Nacional - LDB (9394/96) que em seu artigo $n^{\circ} 23$ prevê como forma de organização escolar. A princípio fortemente ligado a necessidade de responder aos altos índices de reprovação e evasão escolar, os ciclos sofrem inúmeras críticas que vão desde sua associação à progressão continuada, ao construtivismo como forma de flexibilização do saber e autoconstrução do conhecimento.

A partir dos anos 1990, diferentes modalidades de escola em ciclos foram implantadas em redes estaduais e municipais: ciclos inicial, intermediário e final, Ciclos de Aprendizagem, Ciclos de Formação, Regime de Progressão Continuada, entre outras. Uma análise mais detalhada de cada uma dessas modalidades indica que há diferenças entre elas.

Cunha (2012) apresenta os ciclos como opção das reformas educacionais no país e como uma orientação presente nos Parâmetros Curriculares Nacionais (PCNs) de 1997, segundo ele: "os PCNs trazem orientações gerais para o processo de ensino-aprendizagem no ensino fundamental, ratificam que essa estru- 
tura (ciclada) possibilita trabalhar melhor com as diferenças e está coerente com os fundamentos da psicopedagógicos."

Em 1998, algumas redes de ensino implantaram o Regime de Progressão Continuada, que fora indicado na Lei n. 9394/96 (LDB). Este é o caso da Rede Estadual de São Paulo, por exemplo. O artigo 23 da referida lei diz que a Educação Básica poderá ser organizada em séries anuais, períodos semestrais, ciclos, alternância regular de períodos de estudo, grupos não seriados, entre outras modalidades.

O regime de progressão continuada foi incluído no parágrafo $2^{\circ}$ do artigo 32: "Os estabelecimentos que utilizam a progressão regular por série podem adotar no ensino fundamental o regime de progressão continuada, sem prejuízo da avaliação do processo de ensino e aprendizagem, observadas as normas do respectivo sistema de ensino" (Brasil, 1996). Nesse regime, geralmente, os anos iniciais e finais do Ensino Fundamental são divididos em dois ou mais ciclos e a reprovação é possível apenas no final de cada ciclo. No entanto, a duração pode variar de uma rede para outra.

\section{O TEMPO DE APRENDIZAGEM NA ESCOLA ORGANIZADA EM CICLOS}

O termo "ciclos" vem sendo utilizado no Brasil e em outros países para designar uma forma de organização da escolaridade que pretende superar o modelo da escola graduada, organizada em séries anuais e que classifica os estudantes durante todo o processo de escolarização. Com essa nova forma de organização, os anos da escolaridade obrigatória são divididos em ciclos de 2,3 ou 4 anos. A reprovação é possível apenas no final de cada ciclo e, em algumas experiências, ela é totalmente eliminada e substituída por outras formas de progressão dos alunos.

Como citado anteriormente e, segundo estudos de Miranda (2009), os ciclos já foram experimentados em países desenvolvidos como Espanha, Bélgica, 


\section{EDUCAÇÃO DO CAMPO:}

SABERES E EXPERIÊNCIAS DE PRÁTICAS PEDAGÓGICAS NO CONTEXTO EDUCACIONAL

Canadá, Suíça e a França, cuja justificativa central era assegurar os processos escolares, rompendo com a fragmentação e respeitando os ritmos diferenciados, a fim de superar o "fracasso escolar". Na América Latina, além do Brasil, a Argentina implanta os ciclos em 1993 (MAINARDES, 2009/201).

Na França, as noções da organização escolar em ciclos derivam do Plano de Metas Langevin-Wallon elaborado entre os anos de 1946 e 1947 na França (MAINARDES, 2009/2011). Entre as metas prevista no plano, Mainardes (2011) destaca:

a) igualdade e diversidade, significando que todas as crianças, independentemente, de suas origens familiares, sociais, étnicas, têm igual direito do desenvolvimento máximo das características de sua personalidade; b) reconhecimento de igual dignidade para todas as funções sociais, não menosprezando as habilidades de trabalho manual ou inteligência prática em relação a outras habilidades; c) em uma democracia devem-se proclamar e proteger os direitos dos mais fracos e de todos à Educação, garantindo o desenvolvimento pleno das habilidades individuais; d) valorização de uma cultura geral, para que a especialização técnica não limite a compreensão dos problemas mais amplos, ou seja, a formação do trabalhador não deve prejudicar a formação do homem, e sim caracterizar-se como uma formação complementar para um amplo desenvolvimento humano.

No Brasil a primeira experiência de escola em ciclos foi na década de 1980, em São Paulo, muito embora esse termo já apareça durante a Reforma de 1930, associado às políticas de não reprovação (MAINARDES, 2009).

Conforme Mainardes (2001), nesse contexto em que grupos políticos e educadores progressistas passam a assumir cargos importantes nas instâncias mediadoras, medidas inovadoras são implantadas na escola pública, entre elas, o Ciclo Básico de Alfabetização.

Esse processo só é legitimado pela Lei de Diretrizes e Base da Educação Nacional (9394/96) em 1996, que reconhece no artigo de $n^{\circ} 23$ os ciclos como forma de organização escolar. Diz o texto, “a educação básica poderá organizar-se em séries anuais, períodos semestrais, ciclos, alternância regular de períodos de estudos, grupos não-seriados, com base na idade, na competência e em outros critérios" (LDB, 1996). 
SABERES E EXPERIÊNCIAS DE PRÁTICAS PEDAGÓGICAS NO CONTEXTO EDUCACIONAL

Os Ciclos vêm apresentando possibilidades de debater além da lógica linear e devem ser compreendidos como articuladores do dinâmico e complexo processo de desenvolvimento e de aprendizagem dos sujeitos. Não podem apenas legitimar a mudança da realidade formal escolar, mas também oferecer a possibilidade de superá-la em todas as suas configurações de ensino conhecidas, como, por exemplo, o próprio processo de avaliação que é previsto nas desigualdades do desenvolvimento e da aprendizagem entre os sujeitos.

Esse novo modo de pensar exige definição de princípios, metas, conhecimentos próprios, de acordo com as idades, principalmente aos grupos de idade-ciclo. Se estivermos numa lógica de seriação podemos enquadrar o processo de ensino em sequências anuais, semestrais ou ainda bimestrais, com conteúdos e tempos graduados. Contrariamente ao que ocorre nos Ciclos, os tempos têm outra dinâmica, mais extensa e ressignificada a partir das temporalidades ou da condição humana do interagir socioantropológico (os tempos da vida). Os ciclos da vida são processuais, pois não cessam na prescrição ou no conceito final sobre as vivências conquistadas.

Assim, na escola do ciclo, o tempo de aprendizagem é o tempo do desenvolvimento da vida humana, que passa por diferentes ciclos (infância, adolescência, juventude, adulto e velhice). Compreender como se aprende em cada ciclo da vida passa a ser pré requisito para trabalhar os conteúdos escolares.

O Ciclo não leva somente em conta os conteúdos acadêmicos, mas sim o indivíduo num todo, ele não é fragmentado, mas visto dentro de um contexto que fará a diferença, pois ao valorizar o conhecimento que o ser humano traz de suas vivências para a escola, este sentirá como parte dos processos de ensino e aprendizagem. A socialização e a troca de experiências ocorridas entre os sujeitos nos diferentes contextos onde convive, traz novos conhecimentos, sendo o estudante visto como agente do seu conhecimento, um ser ativo e não um espectador. 
SABERES E EXPERIÊNCIAS DE PRÁTICAS PEDAGÓGICAS NO CONTEXTO EDUCACIONAL

A implantação de programas de organização da escolaridade em ciclos tem causado grande debate entre pesquisadores, professores, pais, mídias e sindicatos. Uma das razões desse debate é o fato de que a escola em ciclos representa uma mudança radical em relação ao modelo da escola convencional, geralmente seriada. Além disso, a escola em ciclos traz uma série de implicações para a organização e a gestão da escola, para o trabalho pedagógico na sala de aula, para a avaliação, para o relacionamento da escola com os pais e a comunidade, bem como para o próprio relacionamento dos alunos com a escola e com o conhecimento.

Em um sentido epistemológico geral, a proposta da escola em ciclos está comprometida com a transformação do sistema educacional. A escola em ciclo questiona a lógica da escola graduada, sua estrutura, organização e finalidades. As limitações mais visíveis da escola graduada são os elevados índices de reprovação, a evasão escolar e os alunos em situação de distorção idade/série (em decorrência das reprovações, da evasão ou do ingresso tardio na escola).

Assim, a escola em ciclos propõe uma ruptura com o modelo da escola graduada (considerado excludente e seletivo), com a reprovação e com o fracasso escolar e, por conseguinte, a sua transformação em um sistema educacional não-excludente e não-seletivo.

A respeito da organização em ciclos, Santos (2005), expressa que:

É uma organização que parte do pressuposto de que cada tempo de vida do indivíduo constitui a formação e desenvolvimento cognitivo, afetivo, social, cultural, ético, corpóreo, etc. Nessa concepção de educação o importante é respeitar e entender os tempos da vida humana, considerando os ciclos de socialização, de aprendizados, de formação humana.

A esse respeito, Lima (2000) pondera que seria um equívoco considerar o ciclo como uma proposta voltada àqueles que têm dificuldades de aprendizagem ou que fracassam na escola ou que os ciclos têm apenas a finalidade de acabar com a repetência. Para ela, a educação por ciclos de formação "é uma organização do tempo escolar de forma a se adequar melhor às características biológicas 
SABERES E EXPERIÊNCIAS DE PRATICAS PEDAGÓGICAS NO CONTEXTO EDUCACIONAL

e culturais do desenvolvimento de todos os alunos. Não significa, portanto, 'dar mais tempo para os fracos', mas, antes disso, é dar o tempo adequado a todos.

\section{LIMITES E DESAFIOS DA ORGANIZAÇÃO DA ESCOLA CICLADA}

A política de ciclos é polêmica e, não raro, torna-se o foco de discussões e disputas. Há diferentes grupos de debate: os intelectuais e pesquisadores, os gestores do sistema educacional, os políticos, os profissionais da educação, os sindicatos e associações de professores, os pais, a mídia, entre outros. Entre esses grupos, alguns defendem a escola em ciclos como uma proposta viável; outros criticam a proposta dos ciclos ou a forma como elas têm sido implementadas.

Vale ressaltar que, para o êxito da proposta, não basta, automaticamente, transformar as séries em ciclos. A mudança só ganha corpo e realmente revoluciona a partir de um repensar de antigas formas de currículo, avaliação, relação entre professores e estudantes, entre outros aspectos que traduzem a busca cotidiana de mais qualidade no ensino, a partir da transformação da escola, currículo, e consequentemente, do processo avaliativo de caráter classificatório e excludente, marcado pela aprovação versus reprovação ao final de cada série, em um processo inclusivo, interativo e de promoção dos sujeitos.

Os Ciclos vêm se apresentando como possibilidades de debatef além da lógica linear e devem ser compreendidos como articuladores do dinâmico e complexo processo de desenvolvimento e de aprendizagem dos sujeitos. Não podem apenas legitimar a mudança da realidade formal escolar, mas também oferecer a possibilidade de superá-la em todas as suas configurações de ensino conhecidas, como, por exemplo, o próprio processo de avaliação que é previsto muitas vezes pelas desigualdades no desenvolvimento e na aprendizagem entre os sujeitos.

Esse novo modo de pensar exige definição de princípios, metas, conhecimentos próprios, de acordo com as idades, principalmente aos grupos de idade- 


\section{EDUCAÇÃO DO CAMPO:}

SABERES E EXPERIÊNCIAS DE PRÁTICAS PEDAGÓGICAS NO CONTEXTO EDUCACIONAL

-ciclo. Se estivermos numa lógica de seriação podemos enquadrar o processo de ensino em sequências anuais, semestrais ou ainda, bimestrais. Contrariamente ao que ocorre nos Ciclos, os tempos têm outra dinâmica, mais extensa e ressignificada a partir das temporalidades ou da condição humana do interagir sócio-antropológico (os tempos da vida). Os ciclos da vida são processuais, pois não cessam na prescrição ou no conceito final sobre as vivências conquistadas.

Segundo Miranda (2005), na escola dos ciclos o importante é o sujeito estar na escola, pois estará aprendendo algo, sendo este espaço fundamental para a "experiência da cidadania, da convivência e da formação dos valores sociais".

Embora haja concordância na importância dos estudantes permanecerem na escola, ela precisa ser espaço de conhecimento para poder garantir sua função social e contribuir na humanização dos sujeitos, é extremamente preocupante que a escola seja apenas espaço de convivência e de aprendizados de valores e ainda mais na escola dos trabalhadores onde o questionamento dos valores capitalista e aprendizagem/construção de novos valores são fundamentais.

Franco (2001) declara que a organização da escolaridade em Ciclos, cujas experiências pioneiras surgiram na década de 60, representa uma alteração radical na organização escolar, convencionalmente estruturada em séries. Provoca, desta forma, alterações fundamentais na concepção de ensino, aprendizagem e avaliação, bem como, diferenciados níveis de resistência da classe docente e da opinião pública em geral. Segundo o autor,

A existência, na escola, de uma proposta pedagógica conscientemente implementada, de suficientes estratégias de supervisão e acompanhamento do trabalho pedagógico, além de condições de trabalho adequadas, parecem fundamentais para o êxito de medidas dessa natureza. No âmbito do sistema de ensino, há necessidade da avaliação permanente dos resultados obtidos e das dificuldades encontradas, garantindo, assim, o fortalecimento da função social da escola. Sem o esforço conjunto dos gestores do sistema educacional, das unidades escolares, dos educadores e demais profissionais envolvidos, vinculado aos esclarecimentos feitos aos pais e alunos, mudanças tão radicais como a organização em ciclos poderão fragilizar, ainda mais, a estrutura e o funcionamento 
SABERES E EXPERIÊNCIAS DE PRÁTICAS PEDAGÓGICAS NO CONTEXTO EDUCACIONAL

das escolas, causando prejuízos muito sérios aos processos de aprendizagem e constituição de sujeitos. (FRANCO, 2001, p. 51).

O autor conclui que o Ciclo de Formação Humana é uma medida complexa que exige comprometimento político dos gestores, ampliação dos investimentos nos setores educacionais, bem como, cuidadoso acompanhamento do processo de aprendizagem para delineamento de intervenções, garantindo a apropriação, pelos alunos, dos níveis desejados de aprendizagem.

\section{AVALIAÇÃO NOS CICLOS DE FORMAÇÃO}

As questões relacionadas à avaliação da aprendizagem precisam ser compreendidas em conjunto com as mudanças propostas para o currículo, metodologia, gestão da escola, formação continuada, relação escola-família e infraestrutura disponível na escola. Em alguns casos, a avaliação da aprendizagem recebe uma atenção prioritária pelas redes de ensino, uma vez que a avaliação está estreitamente relacionada ao sistema de promoção dos alunos (eliminação da reprovação).

Assim, um dos desafios dos estudos sobre avaliação da aprendizagem nos ciclos é buscar compreender essa temática em uma perspectiva de totalidade, analisando as relações da avaliação da aprendizagem com os demais aspectos que compõem a política de ciclos.

Assim, um dos principais desafios da implantação dos ciclos e da mudança da avaliação da aprendizagem é o da criação de programas de ciclos que possuam uma articulação orgânica entre currículo, metodologia, avaliação e formação continuada de professores e que priorizem a formação dos professores que possam avançar em sua prática pedagógica de forma a garantir a aprendizagem efetiva de todos os alunos.

Importantes pesquisas sobre o contexto de sala de aula indicam que a prática pedagógica bem conduzida e orientada pode sobrepor-se ao nível socioeconômico familiar dos alunos, sem baixar o nível de exigência conceitual e 
sem aumentar significativamente a quantidade de tempo que a escola tem para oferecer ao aluno.

Os conhecimentos e concepções já dominados pelos professores e as dificuldades concretas de incorporar os princípios da avaliação formativa poderiam constituir o ponto de partida do processo de formação continuada, seja ele desenvolvido pelas secretarias de educação ou pelas escolas.

Assim, a desgastada ideia de resistência à mudança apenas parcialmente explica as dificuldades relacionadas à apropriação de novas possibilidades da avaliação, uma vez que é preciso considerar as condições de produção do trabalho docente, bem como as condições gerais do trabalho docente, dos projetos institucionais e da formação continuada oferecida.

\section{IMPLANTAÇÃO DO CICLO DE FORMAÇÃO HUMANA NA TURMA DE EDUCAÇÃO INFANTIL (MULTIGRUPO) DA ESCO- LA MUNICIPAL JOSÉ PEREIRA DURVAL}

A Escola Municipal José Pereira Durval, situada no povoado de Umbuzeiro, a seis quilômetros da cidade de Irecê, no estado da Bahia, atende aos alunos a partir do G-3 da Educação infantil até o $5^{\circ}$ ano do Ensino Fundamental. Faz fronteira ao Norte com o povoado de Baixão do Zé Preto, ao Sul com o Povoado de Queimada Nova dos Rodrigues, ao Leste com a sede do município e ao Oeste com a Vila de Itapicuru.

Umbuzeiro tem uma população de aproximadamente um mil, habitantes, sua economia é baseada na agricultura. Possui, além da escola, um posto de saúde, água encanada, energia elétrica, associação comunitária, igrejas católica e evangélica, acesso através de estrada asfaltada da sede do município até centro da comunidade.

A escola é uma grande referência na comunidade. Se configura como cenário de diversos eventos e acontecimentos importantes que agrega boa parte dos povos da referida localidade. Funciona desde 1983 e atualmente atende a 60 alunos, com os segmentos da educação infantil e ensino fundamental. Sendo 
SABERES E EXPERIÊNCIAS DE PRATICAS PEDAGÓGICAS NO CONTEXTO EDUCACIONAL

duas turmas no turno matutino, grupo 5 e $1^{\circ}$ ano, classe multietapa (junção de alunos da educação infantil e ensino fundamental) e $2^{\circ}$ e $3^{\circ}$ ano, classe multiano (alunos do ensino fundamental, porém de anos diferentes). No turno vespertino com mais duas turmas, $4^{\circ}$ e $5^{\circ}$ ano, também multiano e educação infantil (multigrupo).

A forma de organização de ensino é a antiga multisseriada, que no contexto da educação do campo nasceu como uma solução para levar educação formal aos setores rurais que na maioria das vezes não há muita crianças para formação de uma turma seriada, e de acordo com os padrões do sistema é obrigatório haver uma quantia significativa de alunos para que se torne possível regulamentar a matrícula de todos perante Lei.

A multissérie é uma organização das escolas do campo para agregar educando de duas ou mais séries/anos em uma mesma sala, com apenas um (a) professor (a). No entanto, com a mudança de nomenclatura as mesmas passaram a ser chamadas de multigrupo e multiano.

Em função da pesquisa, a classe observada foi a turma de educação infantil da professora Daniela Santos, que atende aos alunos de 2, 3 e 4 anos, no turno vespertino, a conhecida multigrupo, por aglomerar crianças de grupos diferentes. Segue o gráfico com a quantidade de alunos por ano:

\begin{tabular}{|c|c|}
\hline Turmas & Quantidade \\
\hline Ano 02 & 06 \\
\hline Ano 03 & 04 \\
\hline Ano 04 & 05 \\
\hline
\end{tabular}

Se para a educação infantil, o ciclo de formação humana não teve tanto impacto por considerar esse segmento um campo de práticas e experiências muito semelhantes ao modelo de Ciclo de Formação, a escola pesquisada, especificamente a sala que aconteceu a investigação, onde a forma de organização já 
SABERES E EXPERIÊNCIAS DE PRÁTICAS PEDAGÓGICAS NO CONTEXTO EDUCACIONAL

traz no seu bojo as mesmas características da modalidade de ciclos de formação no que tange aos diferentes ritmos e tempos de aprendizagem (multigrupo), a proposta foi bem aceita.

A professora relata que não teve dificuldade para iniciar o trabalho na perspectiva de ciclos, no que diz respeito a prática pedagógica e a organização dos ambientes de aprendizagem, porém ressalta a necessidade de mais estudos reflexivos, para assim dialogar melhor com seu fazer docente.

Em relação ao processo de ensino e aprendizagem por meio dos ambientes, foi realizada uma formação em serviço, onde a gestão da escola abordava a relevância desses espaços na construção do conhecimento das crianças. Nesse ínterim, os mesmos estão sendo construídos gradativamente, sendo que os espaços internos e externos estão sendo aproveitados. Estão sendo realizadas mudanças na estrutura física e metodológica da escola, procurando deixá-la um espaço vivo, agradável e estimulante tanto para os estudantes quanto para os professores.

Segundo a gestão da escola, durante a implantação dos ciclos e dos Ambientes de Aprendizagem, serão realizadas encontros nos quais professores, gestão, comunidade escolar e local discutirão e reformularão o projeto político pedagógico tantas vezes quanto necessário. Para fundamentar o referido parágrafo, Maturana (2005) diz que o educar é uma transformação estrutural contingente com uma história no conviver, e o resultado disso é que as pessoas aprendem a viver de acordo com o conviver da sua comunidade.

A coordenadora pedagógica enfatiza a importância do aproveitamento dos ambientes externos, levando em consideração que as escolas do campo dispõem desses espaços e que contextualiza com a realidade dos sujeitos envolvidos, tornando as aprendizagens mais significativas e condizentes com a vivência dos alunos.

Assim, a contemporaneidade traz novos rumos para toda a comunidade escolar. Tanto professores quanto os demais profissionais da educação devem 
se questionar sobre a possibilidade da construção de um mundo diferente, impulsionado por uma educação transformadora, que pressupõe a valorização das diferenças e a não linearidade e fragmentação do conhecimento.

Entretanto, com a implantação do Ciclo de Formação humana, as mudanças são evidentes, desde um trabalho educacional norteado pelas idades da vida e da formação humana, do planejamento, da organização das atividades, dos conhecimentos até a intervenção do educador no processo de ensino aprendizagem. E nessa mesma lógica, o Projeto Político Pedagógico deve estar em consonância com o fazer docente, numa perspectiva práxica.

\section{CONSTRUÇÃO DOS AMBIENTES DE APRENDIZAGEM DA ESCOLA PESQUISADA}

Desde que a proposta de Ciclo de Formação Humana foi implantada na Educação Infantil da Rede Municipal de Irecê, a escola que foi alvo dessa pesquisa seguiu a mesma lógica, no que diz respeito a forma de organização através dos ambientes de aprendizagens.

A gestão da escola, ciente de que o estudante é o centro do processo educacional, um ser ativo na construção de seu conhecimento, passa a pensar na construção dos ambientes, de forma que esses espaços possam desafiar e motivar os alunos à exploração, à reflexão e à descoberta, e nessa mesma intenção, modificar a estrutura e a organização da escola.

Em conformidade com a BNCC, que reforça que as crianças devem ser estimuladas a explorar livremente, porém, em contextos cuidadosamente planejados pelo professor, essa intencionalidade se expressa, muitas vezes, na organização dos espaços, na escolha dos materiais que serão oferecidos para as crianças etc.

Assim, o trabalho que vem sendo pensado na perspectiva de Ciclos de Formação Humana, especialmente os ambientes de aprendizagens, tem potencializado o saber fazer coletivo. Para isso, os momentos de estudos, algumas 
SABERES E EXPERIÊNCIAS DE PRÁTICAS PEDAGÓGICAS NO CONTEXTO EDUCACIONAL

mudanças na estrutura física e nas práticas didático pedagógicas, foram e continuarão sendo necessários para melhor efetivar a proposta e principalmente torna a escola interessante, proporcionando vivências diferenciadas para as crianças. Sem dúvida, os ambientes de Aprendizagens são espaços propícios para o desenvolvimento de diferentes formas de ensinar e aprender.

Na concepção de Fornero (1998), de um modo mais amplo pode se definir o ambiente como um todo indissociável de objetos, odores, formas, cores, sons, e pessoas que habitam e se relacionam dentro de uma estrutura física determinada que contém tudo e que ao mesmo tempo, é contida por todos esses elementos que pulsam dentro dele como se tivessem vida. Por isso, dizem que o ambiente "fala", transmitem sensações, evoca recordações, passa segurança ou inquietação, mas nunca deixa as pessoas indiferentes.

Ainda pautada na autora referendada no parágrafo anterior, é nesse mesmo sentido que "o ambiente fala". E como elemento do currículo, ele pode, em parceria com o educador, promover as aprendizagens, estando organizado com objetivos e intenções claras, as quais visam à autonomia e ao desenvolvimento das crianças. Para isso,

Qualquer observador externo que tenha acesso a uma sala de aula pode perceber quase de imediato o ambiente de aprendizagem que existe na mesma. Praticamente poderíamos dizer: "diga-me como organiza os espaços de sua aula e lhe direi que tipo de professor(a) você é e que tipo de trabalho você realiza". (FORNERO, 1998,

Assim, a partir da observação realizada na escola pesquisada, foi perceptível que a mesma não foi preparada adequadamente para receber esta nova ideia de ensino, principalmente por se tratar de uma escola composta por turmas multisseriadas, organização típica de escola do campo, porém nessa ocasião, a rede municipal de Irecê, desde quando iniciou a implementação por ciclos de formação humana nas escolas pilotos em 2017, teve a preocupação de oferecer aos educadores, formação continuada e em serviço para toda rede de ensino, e esses momentos formativos foram estendidos, justamente por compreender que essa nova organização carece de muitos estudos e pesquisas. 
SABERES E EXPERIÊNCIAS DE PRATICAS PEDAGÓGICAS NO CONTEXTO EDUCACIONAL

Portanto, é preciso salientar que a proposta e a idealização do Ciclo de Formação Humana necessitam de uma base estrutural que promova a sustentação dos profissionais envolvidos, para que o seu objetivo seja alcançado de forma efetiva, para que o aluno saia deste processo capaz de identificar suas possibilidades e buscar pela sua realização pessoal e profissional, traçando seu próprio caminho.

\section{CONSIDERAÇÕES FINAIS}

A pesquisa buscou compreender como se deu a implantação do ciclo em uma turma multigrupo de uma escola do campo. Com o estudo na classe observada, analisou-se que não há uma organização única devido à diversidade de realidades, com isso não se pode ter um sistema de ensino engessado onde todas as escolas tenham que trabalhar da mesma forma.

Fez-se entender através dos estudos que a proposta de ciclo não é mais um modelo de ensino isolado, mas que já foi legitimado pela LDB e que está se tornando uma realidade em diversos ambientes escolares.

No que tange as possibilidades e potencialidades, tanto as famílias como os professores relataram que consideram esse novo modelo de organizar os ambientes como uma forma diferenciada de trabalhar, que desafia o trabalho docente, pois permite considerar no planejamento as múltiplas linguagens, abrangendo uma visão integral da criança.

Também enfatizam que a troca de espaço é interessante para as crianças, em função do movimento que imprime no dia a dia e pelo fato de as salas auxiliarem na organização da rotina e favorecerem a independência. Desse modo, tais aspectos se configuram como potências dessa proposta de trabalho.

Enfim, ao propor a organização em Ciclos de Formação Humana, a escola vem tentando colocar a ação educativa da mesma em movimento. Ciclo é movimento, não nos deixa parados, é processo, é relação, é agrupar e reagrupar-se para aprender e ensinar. Assim, a implementação da escola em ciclos se faz ne- 
cessária, pois é um grande passo na busca de uma sociedade mais igualitária, oferecendo o acesso, permanência e possibilitando o real desenvolvimento dos alunos.

\section{REFERÊNCIAS}

ARROYO, M. G. Organizações escolares flexíveis: Os Ciclos de Formação Parte de um diálogo realizado entre o professor Miguel Arroyo e a profa. Eustáquia, da Faculdade de Educação da Universidade Federal de Minas Gerais, em 2003.

BRASIL, Constituição da República Federativa do Brasil. Promulgada em 5 de outubro de 1988. Brasília: Senado Federal, 198

CUNHA, K. S.; SILVA, J. P.; RAMOS, J. R. Educação do Campo no Brasil: um significante vazio. Revista Inter-Ação. v. 42, n. 2, mai./ago./ 2017. NO PRELO.

FERNANDES, Claudia de Oliveira. Avaliação sem reprovação: elementos para o debate. In: FETZNER: Andrea Rosana (org.). Avaliação: desejos, vozes, diálogos e processos. Ciclos em Revista: Rio de Janeiro: Wak Ed., 2008.

FORNERO, Lina Iglesias. A Organização dos Espaços na Educação Infantil. In: ZABALZA, Miguel Antônio (Org.). Qualidade em Educação Infantil. Porto Alegre: Artmed, 1998, p. 229-281.

FREIRE, Paulo (1975). Pedagogia do Oprimido. Textos 5. 2a . Edição. Porto: Afrontamento. Ed. João Barrote.

FREITAS, Luiz C. "Ciclos, seriação e avaliação- confronto de lógicas", Moderna, SP, 2003 Disponível em: http://xa.yimg.com/kq/groups/19853454/1869283613/ name/LCF-5.pdf. Acessado em: 04/01/2018

KRUG, Andréa. Ciclos de Formação. Rio Grande do Sul, 2006

LOMBARDI, José Claudinei. Educação e ensino na obra de Marx e Engels. Editora Alínea, Campinas: 2008.

MAINARDES, Jefferson. A organização da escolaridade em ciclos e as políticas de currículo. Revista e-curriculum, São Paulo, v.7 n.1 Abril/2011 Disponível em: http://revistas.pucsp.br/index.php/curriculum, acessado em: 06/01/2014 
MIRANDA, Marília G. A organização escolar em ciclos e a questão da igualdade substantiva. Revista Brasileira de Educação v. 14 n. 40 jan./abr. 2005

MATURANA, Humberto. A ontologia da realidade. Belo Horizonte: Ed. UFMG, 2002.

PEREIRA, Luiza R. A implantação do sistema de ciclos no ensino fundamental como elemento da política. Dissertação (Mestrado em Educação) - Centro de Ciências Humanas e Sociais, Universidade Federal do Mato Grosso do Sul, Campo Grande, 2007.

PERRENOUD, Philippe. Práticas pedagógicas, profissão docente e formação. Perspectivas sociológicas. Lisboa: Publicações Dom Quixote e IIE, 1993.

PIAGET, Jean. A psicologia da criança. Rio de Janeiro, Bertrand Brasil, 1989.

SANTOS, Josiane G. O compromisso social da escola organizada em ciclos: por uma verdadeira aprendizagem. 2005, Dissertação de Mestrado. Disponível em: http://tede.utp.br/tde_busca/arquivo.php?codArquivo=124, acessado em: $27 / 12 / 2017$

SILVA, Paulo Roberto. Fundamentos político-pedagógicos para a educação do campo I: a escola do campo. In: ZIENTARSKI, Clarice; PEREIRA, Karla Raphaella Costa; FREIRE, Perla Almeida Rodrigues. Escola da Terra Ceará: conhecimentos formativos para a práxis docente do/no campo. Assis: Triunfal, 2016. p. 293-302. 


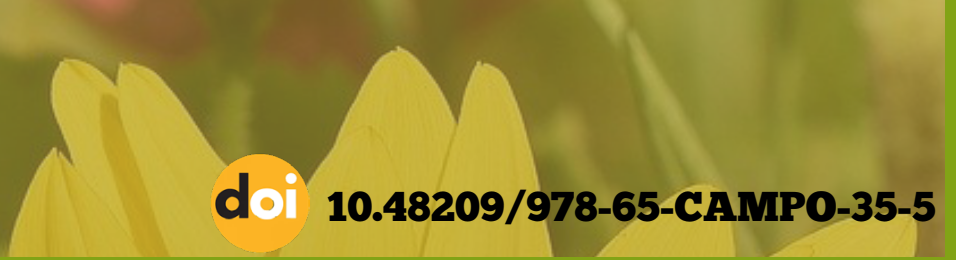

\section{CAPITULOS}

A CPNHRAMIDADEDA CATHEORIA YUAMAIHO FM PROJFOS DE

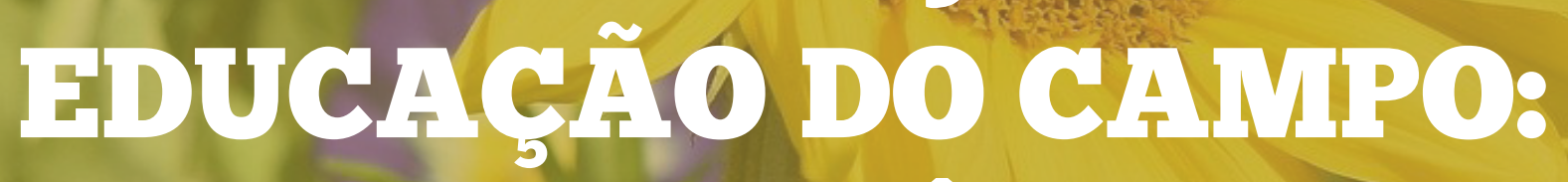

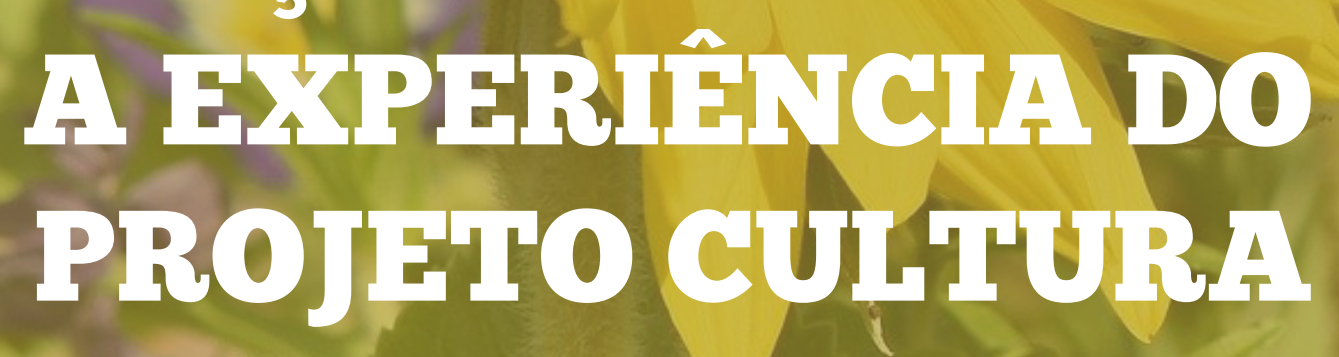
AMBIFNHAT NO IHPRIHÓORO CAIPIRA

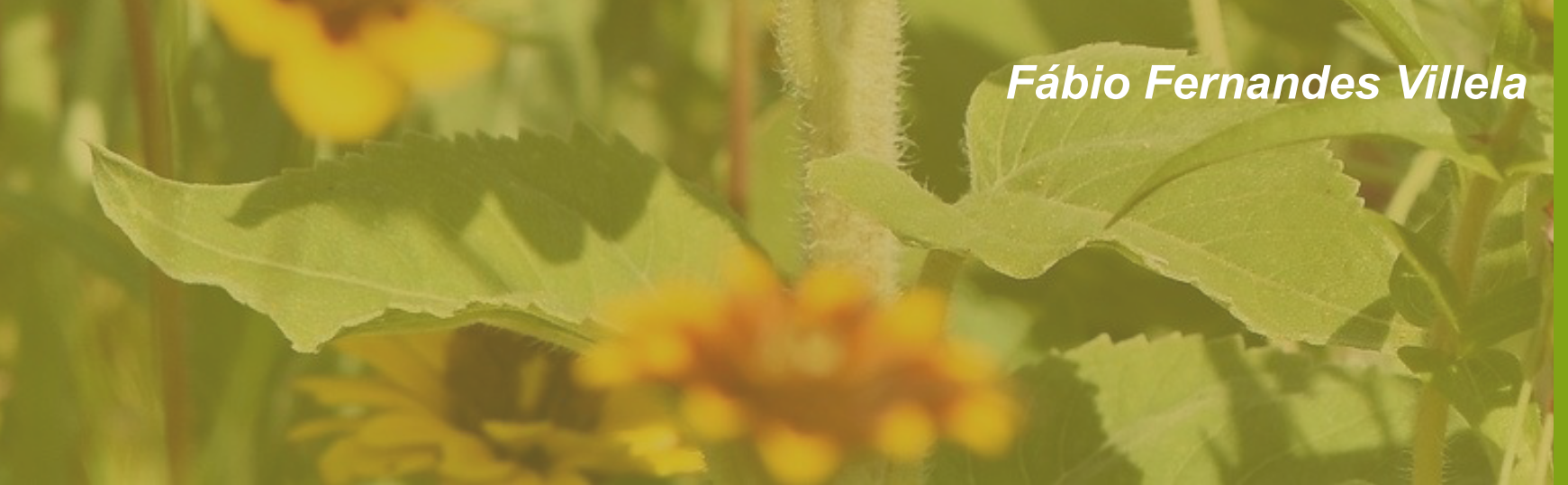




\section{INTRODUÇÃ}

Este texto, que integra o e-book: "Educação do Campo: Saberes e Experiências de Práticas Pedagógicas no Contexto Educacional", foi apresentado num evento em $2017^{2}$. Tendo em vista fomentar a popularização da Ciência e Tecnologia (C \& T), foi disponibilizado a seguir, com pequenas alterações. O e-book em questão, é um importante espaço de socialização das experiências teóricas e/ ou práticas pedagógicas sobre Educação do Campo nos seus diferentes níveis e espaços de atuação educacional. Conforme a proposta, é uma obra de resistência e possibilidades, o qual tem por objetivo divulgar e articular os debates e as experiências das práticas pedagógicas em educação do campo realizadas no contexto educacional.

O texto aborda a centralidade da categoria trabalho em projetos de educação do campo, a partir do projeto de ensino-pesquisa-extensão intitulado: Cultura ambiental no território caipira. O projeto possui como objeto de estudo a história e os saberes tradicionais das mulheres do território caipira, tendo como referencial teórico-metodológico a teoria do valor-trabalho. Os resultados do projeto, apresentados neste texto, são a elevação de escolaridade de jovens e adultos associada à qualificação social e profissional, possibilitando novas aprendizagens na região noroeste paulista. O texto está organizado da seguinte maneira: (1) o trabalho como categoria-chave na pedagogia histórico-crítica; (1.1.) o trabalho das mulheres no território caipira; (1.2.) projeto de trabalho na perspectiva da pedagogia histórico-crítica; (2) resultados e discussão; (3) considerações finais; e (4) referências.

\section{O TRABALHO COMO CATEGORIA-CHAVE NA PEDAGOGIA HISTÓRICO-CRÍTICA}

A principal referência da pedagogia histórico-crítica é a centralidade da teoria do valor-trabalho de Marx, conforme demonstra Saviani (2012, 2011, 2007 $2 \quad$ Anais do I Seminário Internacional e IV Seminário Nacional de Estudos e Pesquisas Sobre Educação no Campo: Políticas Educacionais para o Meio Rural na América Latina, Universidade Federal de São Carlos - Campus São Carlos. 
e 2003). Para o autor, toda a educação está organizada a partir do conceito, fato, entendimento e realidade do trabalho: "o que define a existência humana, o que caracteriza a realidade humana é exatamente o trabalho" (SAVIANI, 2003, p. 132). Portanto, o autor ancora a pedagogia histórico-crítica como uma pedagogia de inspiração marxista (Cf. Saviani, 2011). No entanto, a centralidade da teoria do valor-trabalho de Marx está sob o fogo cruzado de perspectivas antagônicas nos dias de hoje.

Retomando o debate sobre a centralidade do valor-trabalho em Marx, desenvolvida em nossa tese de doutorado (VILLELA, 2013), observamos que, nos dias de hoje, há uma contraposição entre duas perspectivas que se articulam em torno da análise sobre a centralidade da teoria do valor-trabalho de Marx. A primeira defende que a "ontologia do ser social" se constitui em torno do trabalho e é, portanto, o principal modo de socialização dos sujeitos, tornando-se indispensável para o pleno desenvolvimento do ser humano, isto é, da sua omnilateralidade. Essa tese é defendida principalmente por Antunes (1999), Villela, (2011), entre outros autores.

O outro ponto de vista defende que o trabalho não era o fundamento dos "modos de socialização". Segundo essa perspectiva, o trabalho não ocupa mais um lugar central nas sociedades industrializadas contemporâneas enquanto valor e peça central dos processos de socialização. Temos uma perspectiva diametralmente oposta, conforme já expusemos em diversos trabalhos, especialmente em Villela (2014a).

Colocando a educação no contexto desse debate e, segundo nosso interesse, a pedagogia histórico-crítica também refuta a tese do fim da centralidade do valor-trabalho ao afirmar que o ponto de partida da humanização é a relação entre trabalho e educação e nessa relação há uma identidade (SAVIANI, 2011, p. 154). Uma das ideias-chaves da pedagogia histórico-crítica, de acordo com Saviani (2003, p. 13), é que a essência do trabalho educativo consiste no "[...] ato de produzir, direta e intencionalmente, em cada indivíduo singular, a humanidade que é produzida histórica e coletivamente pelo conjunto dos homens". O autor 
afirma que:

[...] os homens aprendiam a produzir sua existência no próprio ato de produzi-la. Eles aprendiam a trabalhar trabalhando. Lidando com a natureza, relacionando-se uns com os outros, os homens educavam-se e educavam as novas gerações. A produção da existência implica o desenvolvimento de formas e conteúdos cuja validade é estabelecida pela experiência, o que configura um verdadeiro processo de aprendizagem. Assim, enquanto os elementos não validados pela experiência são afastados, aqueles cuja eficácia a experiência corrobora necessitam ser preservados e transmitidos às novas gerações no interesse da continuidade da espécie (SAVIANI, 2011, p. 154).

Ainda de acordo com Saviani (2007, p. 152-153), trabalho e educação são características essenciais que definem o ser-humano em sua totalidade. Para Saviani (2007, p. 152-153), trabalho e educação são atividades especificamente humanas, apenas o ser humano trabalha e educa. Para o autor, o homem está previamente constituído como ser que possui propriedades que lhe permitem trabalhar e educar. A definição de "humano" em sua essência consiste em atribuir trabalho e educação ao "ser-humano".

Conforme aponta Saviani (2011), a tarefa de uma pedagogia inspirada no marxismo implica em formular diretrizes pedagógicas que possibilitarão a reorganização do trabalho educativo sob os aspectos das finalidades e objetivos da educação, das instituições formadoras, dos agentes educativos, dos conteúdos curriculares e dos procedimentos pedagógico-didáticos que movimentarão um novo éthos educativo voltado à construção de uma nova sociedade, uma nova cultura, um novo homem.

\subsection{O TRABALHO DAS MULHERES NO TERRITÓRIO CAIPIRA}

A reorganização do trabalho educativo promovido pela pedagogia histórico-crítica, conforme aponta Saviani (2012), continua se desenvolvendo com a colaboração de diversos pesquisadores que vêm aprofundando teórico-metodologicamente as potencialidades dessa concepção pedagógica em campos como: didática (GASPARIN, 2013; GERALDO, 2009), psicopedagogia (SCALCON, 2002), ensino de ciências (SANTOS, 2005) e educação infantil (MARSIGLIA, 
SABERES E EXPERIÊNCIAS DE PRATICAS PEDAGÓGICAS NO CONTEXTO EDUCACIONAL

2011), entre outros. Conforme Geraldo (2009, p. 72) argumenta, as atividades de ensino visam: "a apropriação-assimilação significativa, criativa e crítica dos conhecimentos sistematizados, das habilidades motoras e intelectuais e das atitudes [...] e o desenvolvimento da autonomia intelectual dos alunos".

No projeto de ensino-pesquisa-extensão intitulado: "Cultura ambiental no território caipira: história e saberes tradicionais das mulheres do noroeste paulista" (Cf. Villela, 2016a), procuramos colaborar com a reorganização do trabalho educativo através do desenvolvimento de um projeto de trabalho docente-discente na perspectiva da pedagogia histórico-crítica, conforme Gasparin (2013). A questão principal é desenvolver, nos espaços de Educação de Jovens e Adultos (doravante, EJA), um "projeto de trabalho" (Cf. Kaspchak; Gasparin, 2013) sobre a "história e os saberes tradicionais" do noroeste paulista, tendo como categoria-chave o trabalho das mulheres.

O projeto teve como objetivos gerais a compreensão da história e dos saberes tradicionais das mulheres do "território caipira", tendo como categoria-chave o trabalho das mulheres, e como objetivos específicos a educação de jovens e adultos (EJA), especialmente das mulheres do "território caipira". As razões que justificaram esse projeto foram: a inclusão produtiva das mulheres e a consolidação de redes socioeconômicas da agricultura familiar no âmbito dos territórios rurais e as possibilidades de ações para a inclusão produtiva das mulheres do "território caipira". Teve como resultados a articulação dos saberes com as diferentes áreas do conhecimento, possibilitando a vivência de novos valores, o desencadeamento de ações coletivas, bem como a elevação de escolaridade associada à qualificação social e profissional, possibilitando novas aprendizagens (Cf. Villela, 2016a).

O objetivo deste trabalho é abordar a história e os saberes tradicionais do noroeste paulista - SP, tendo como categoria-chave o trabalho das mulheres. As culturas e os saberes tradicionais, conforme aponta Diegues (1999, p. 15), podem contribuir para a manutenção da biodiversidade dos ecossistemas. Em 
SABERES E EXPERIÊNCIAS DE PRATICAS PEDAGÓGICAS NO CONTEXTO EDUCACIONAL

numerosas situações, esses saberes são o resultado de uma coevolução entre as sociedades e seus ambientes naturais, o que permite a conservação de um equilíbrio entre ambos. Isso nos conduziu ao interesse pela diversidade cultural, que também está ameaçada pela mundialização de modelos culturais dominantes.

As "comunidades tradicionais" e seus saberes são conceitos explicitados na Política Nacional de Desenvolvimento Sustentável dos Povos e Comunidades Tradicionais (PNPCT), em seu terceiro artigo. "Comunidades tradicionais" são grupos culturalmente diferenciados que possuem formas próprias de organização social, que ocupam e usam territórios e recursos naturais como condição para sua reprodução cultural, social, religiosa, ancestral e econômica, utilizando conhecimentos, inovações e práticas gerados e transmitidos pela tradição (BRASIL, 2007).

Considerando os diferentes contextos geográficos e as peculiaridades culturais que envolvem essas comunidades, Diegues (1999) listou 16 territórios com populações tradicionais "não indígenas" brasileiras, dentre elas, os "caipiras ou sitiantes": comunidades, em grande parte de meeiros e parceiros, que sobrevivem em nichos entre as monoculturas do sudeste e do centro-oeste, desenvolvendo atividades agropecuárias em pequenas propriedades, destinadas à subsistência familiar e ao mercado. Diegues (1999, p. 40) distingue as seguintes populações tradicionais não indígenas: caiçaras, caipiras, babaçueiros, jangadeiros, pantaneiros, pastoreio, praieiros, quilombolas, caboclos/ribeirinhos amazônicos, ribeirinhos não amazônicos, varjeiros, sitiantes, pescadores, açorianos, sertanejos/ vaqueiros.

O autor indica, em um mapa, a localização aproximada do território dessas populações, salientando que, no caso dos caipiras, restaram somente alguns enclaves onde elas subsistem. Diegues (1999, p. 40) ressalta que: "não existe uma linha muito definida que separe os territórios dessas populações, ocorrendo mesmo nichos de algumas delas espalhados em áreas fora de suas regiões 
SABERES E EXPERIÊNCIAS DE PRATICAS PEDAGÓGICAS NO CONTEXTO EDUCACIONAL

originais". A partir dessa peculiaridade cultural, foram selecionadas duas escolas parceiras que se encontram em uma região em que parte dos habitantes se identifica como "caipiras".

O "Noroeste Paulista" é uma região do estado de São Paulo que abrange parte ou toda a mesorregião de São José do Rio Preto e, às vezes, também costuma-se incluir a mesorregião de Araçatuba e a microrregião de Lins. É formada pela união de 153 municípios distribuídos em doze microrregiões. Possui uma área total de 50.025 quilômetros quadrados, cerca de $20 \%$ da área do estado e equivalente à área do estado brasileiro do Rio Grande do Norte. O município mais populoso é São José do Rio Preto, com 460 mil habitantes, seguido por Araçatuba (200 mil), Catanduva (114 mil), Birigui (111 mil), Votuporanga (84 mil), Lins (71 mil) e Fernandópolis (64 mil). Essas informações foram retiradas de Noroeste (2014).

Do ponto de vista do trabalho das mulheres inseridas nesses territórios, a dura realidade se estende para além dos afazeres domésticos cotidianos (Cf. Dantas, 2013 e 2010). Todos os dias, elas precisam garantir a sobrevivência de sua família. O objetivo geral é compreender as histórias de vida dessas mulheres e seus saberes, procurando colocar em primeiro plano a visão que as mulheres têm do trabalho, do meio ambiente, da família, da sexualidade e de suas relações sociais, inseridas no "território", em nosso caso, o noroeste paulista. Através de um "projeto de trabalho" e, utilizando métodos qualitativos e quantitativos, nos espaços de educação de jovens e adultos, foi possível conhecer um pouco mais do cotidiano dessas mulheres. Através dessa proposta, se dará visibilidade à condição humana dessas mulheres e será possível compreender e valorizar o conhecimento, a diversidade cultural e os saberes tradicionais construídos nesse território denominado de "caipira" por Diegues (1999).

A questão principal foi desenvolver, nos espaços de EJA, um "projeto de trabalho" (Kaspchak; Gasparin, 2013) sobre a "história e os saberes tradicionais", tendo como categoria-chave o trabalho das mulheres. Para Diegues (1999, p. 
SABERES E EXPERIÊNCIAS DE PRÁTICAS PEDAGÓGICAS NO CONTEXTO EDUCACIONAL

30), conhecimento tradicional é definido como o conjunto de saberes e saber-fazer a respeito do mundo natural, sobrenatural, transmitido oralmente de geração em geração.

Um exemplo de "saber tradicional" da "agricultura familiar" está presente nas cozinhas do "território caipira". A cozinha é um microcosmo da sociedade, fonte inesgotável de saberes históricos, e suas produções podem ser consideradas como "patrimônio gustativo da sociedade". Conforme demonstra Santos (2011), esses "saberes" permitem destacar as identidades locais e regionais; certos pratos podem ser considerados como bens culturais, como lugares de memória, como patrimônio imaterial. Para o autor, uma síntese sobre as cozinhas brasileiras busca explicar influências de culturas alimentares a partir de duas realidades: a autêntica cultura alimentar local e regional e a cultura alimentar oriunda da civilização externa, influenciadora. Tais contatos e simbioses revelam relações e trocas complexas de diferenças, afirmadas e reafirmadas em fecunda assimilação, que redunda numa certa mestiçagem da comida brasileira. Dada essa visão do "saber tradicional" e nosso interesse em investigar o trabalho de mulheres no território caipira, avançamos por meio da pesquisa de alimentos e seus preparos feitos por mulheres caipiras.

O "território caipira" é marcado por "uma civilização do milho", conforme aponta Marins (2004, p. 1-3). Para o autor, na alimentação paulista, a permanência dos saberes dos nativos sempre foi característica marcante. A origem indígena das mães de grande parte das famílias pioneiras, bem como a onipresença de escravas vindas dos sertões fazia com que o cozinhar estivesse presente nas casas ou nas caminhadas pelos interiores selvagens, marcado pelo paladar dos nativos. Mandioca e milho dividiram o pódio no cotidiano das famílias do litoral e do sertão.

Ainda segundo Marins (2004, p. 2), iguarias de milho apiloado ou macerado nos monjolos, uma marca registrada das populações paulistas, eram marcantes nas vilas do planalto paulista, a ponto de Sérgio Buarque de Holanda denomi- 
SABERES E EXPERIÊNCIAS DE PRATICAS PEDAGÓGICAS NO CONTEXTO EDUCACIONAL

nar a sociedade local de "civilização do milho" (Cf. Holanda, 1995, p. 181-189). Canjicas, curaus e pamonhas são ainda muito presentes na culinária paulista, chegando mesmo a fazer parte das alegorias "caipiras" das festas juninas. O fubá moído, recusado por muitos que o consideravam "comida para cachorro", acabou tendo reforço a partir do século XIX devido à sua grande popularidade entre os italianos (que usavam/usam o fubá para fazer polenta, um tipo de curau salgado).

A proposta foi utilizar os parceiros-agricultores do projeto de extensão universitária como foco de intervenção pontual de uma "acupuntura territorial" e visa, em futuro próximo, propagar essa ação para as demais cidades que compõem o território rural "noroeste paulista - SP" (Cf. Lerner, 2003; Garcia, 2012 e Villela, 2016a). O principal parceiro-agricultor nessa primeira etapa de desenvolvimento do projeto foi a Horta Mandalla de Ipiguá (SP), cidade distante 19 km de São José do Rio Preto. O que é a Horta Mandalla de Ipiguá? "Mandala" significa círculo mágico, concentração de energia, e é considerada universalmente, como o símbolo da integração e da harmonia. Inspirados nesse conceito, o casal de agricultores Ceci e Reinaldo criaram em Ipiguá uma horta orgânica em torno de um círculo côncavo de barro rodeado por outros nove círculos com produtos hortifrutigranjeiros, sendo que cada um deles representa um dos planetas do sistema solar. $O$ objetivo é a qualificação social e profissional, possibilitando novas aprendizagens na região noroeste paulista, fortalecendo a "agricultura familiar", que consiste na exploração de uma parcela de terra, tendo como trabalho direto a mão de obra familiar. Passamos às considerações sobre a educação de jovens e adultos (doravante, EJA), especialmente das mulheres, da agricultura familiar no território caipira.

\subsection{PROJETO DE tRABALHO NA PERSPECTIVA DA PEDAGOGIA HISTÓRICO-CRÍTICA}

Nos espaços criados de EJA, conforme aponta Dantas (2013), é relevante que se trabalhe os "saberes tradicionais" dessas populações. Segundo a autora, é primordial que as informações sobre as habilidades e competências dessa co- 
SABERES E EXPERIÊNCIAS DE PRÁTICAS PEDAGÓGICAS NO CONTEXTO EDUCACIONAL

munidade envolvam reflexão, tanto individual como coletiva, pois é esse exercício que permitirá às mulheres e aos homens se reconhecerem como sujeitos do seu contexto social e cultural, os quais, com essa certeza, poderão ser capazes de desenvolver novas relações de inclusão produtiva e a consolidação de redes socioeconômicas da agricultura familiar no âmbito dos territórios rurais.

Diante desse contexto, o trabalho em andamento procura integrar os saberes e analisar a complexidade desses saberes, especialmente das mulheres que constroem conhecimentos e os repassam de geração a geração. Para tanto, é utilizada a experiência de EJA desenvolvida no âmbito do "Projeto Unesp de Educação de Jovens e Adultos" (doravante, Peja - Unesp). O Peja - Unesp (criado na Unesp no ano de 2000, na época, vinculado ao Programa Unesp de Integração Social Comunitária, da Pró-Reitoria de Extensão Universitária - PROEX) tem o objetivo de estabelecer uma política pública para a educação de jovens e adultos, buscando parcerias comunitárias locais e visando à contribuição de recursos para a formação de cidadãos/leitores críticos e participativos, bem como a de professores com a visão de "educadores populares". (Cf. Villela; Tenani e Silva, 2014; Villela et al., 2007 e Villela, 2016c).

Do ponto de vista da EJA, é utilizado um "projeto de trabalho" (Cf. Kaspchak; Gasparin, 2013). Optou-se pelas possibilidades metodológicas do trabalho com projetos, devido à riqueza de material acumulado sobre EJA em comunidades rurais. Dentre as diversas opções de trabalho com projetos, destaca-se: "projetos de ensino", "projetos de trabalho", "projetos da aprendizagem", "temas geradores", "metodologia do complexo temático", entre outros (Cf. Hernández e Rodrigues, 1998). Dessa forma, as metodologias de trabalho com projeto permitem maior flexibilidade de estratégias, viabilizando uma aprendizagem que de fato corresponda às reais necessidades da comunidade.

Somado a essas duas experiências (o Peja - Unesp e o Projeto de TrabaIho), utilizamos o Centro Virtual de Estudos e Culturas do Mundo Rural (Villela, 2014b). Esse projeto foi desenvolvido como recurso didático e ferramenta no ensino de sociologia para os alunos do curso de pedagogia da Unesp de São 
José do Rio Preto (SP), doravante Rio Preto, e estendido, posteriormente, para escolas que manifestaram interesse em desenvolver tópicos da área de Ciências Humanas e suas Tecnologias. Esse trabalho utiliza a metodologia de blog, um website frequentemente atualizado, por meio do qual os conteúdos aparecem em ordem cronológica inversa. Podem conter textos, imagens, áudios, vídeos e animações. Esta metodologia possibilita a disseminação do conhecimento produzido pela universidade na internet gratuitamente. Os conteúdos relacionados ao projeto de trabalho foram desenvolvidos no curso de extensão semipresencial intitulado: Território caipira: uma civilização do milho (Cf. Villela, 2016b). Vejamos, a seguir, alguns resultados e a respectiva discussão.

\section{RESULTADOS E DISCUSSÃO}

No final de 2016 realizamos o curso de extensão semipresencial intitulado: Território caipira: uma civilização do milho (Cf. Villela, 2016b), momento central do projeto de trabalho, conforme mencionado acima. O módulo presencial foi desenvolvido em sala de aula (Ibilce/Unesp) e na Horta Mandalla e o módulo de ensino à distância (Ead) foi realizado no blog de aula: Centro Virtual de Estudos e Culturas do Mundo Rural (Villela, 2004b). A justificativa é desenvolver ações para a inclusão produtiva das mulheres do "território caipira" através da valorização de produtos locais. O curso teve diversos módulos: 1. Cultura Ambiental e Educação do Campo; 2. Manejo da Cultura do Milho; 3. Agricultura Familiar e Agroecologia e 4. Mulheres e Educação do Campo (Cf. Villela, 2014b).

O módulo "Manejo da Cultura do Milho" do curso foi ministrado pelo engenheiro agrônomo Oliver Blanco. A ideia central desse módulo foi a valorização de produtos territoriais com identidade cultural, isto é, o milho, especialmente o crioulo "Cunha", melhorado a partir das experiências e aprendizado dos povos, que sempre o cultivaram para garantir a sobrevivência (Cf. Blanco, 2013). Trata-se de alternativas para manter conhecimentos e sementes livres do patenteamento pelas grandes empresas da produção de sementes, relacionado aos "saberes tradicionais" (Cf. Campos, 2007). As sementes crioulas podem ser 
SABERES E EXPERIÊNCIAS DE PRATICAS PEDAGÓGICAS NO CONTEXTO EDUCACIONAL

adquiridas através de "feiras da troca" (Cf. Villela et al., 2013). O milho utilizado e distribuído aos parceiros deste trabalho é o milho crioulo "Cunha", variedade preservada pelos produtores do município de Cunha, estado São Paulo, os quais estão resgatando uma antiga tradição do milho. Os agricultores de Cunha (SP) resgataram uma antiga tradição do milho na cidade, em contraposição à tecnologia transgênica do milho, no sentido de "conhecer, compartilhar, resistir, pesquisar e semear, a nossa real e absoluta independência" (Cf. Blanco, 2013).

O curso é um momento do desenvolvimento do projeto de trabalho, baseado na didática da pedagogia histórico-crítica, proposta por Gasparin (2013). Segundo essa perspectiva teórico-metodológica, o ponto de partida diz respeito ao nível de desenvolvimento real do educando (especialmente das mulheres), a prática social inicial; o segundo momento, constitui o elo entre a prática social e a instrumentalização, isto é, a problematização; o terceiro relaciona-se às ações didático-pedagógicas para a aprendizagem, denominado instrumentalização; o quarto, a expressão elaborada da nova forma de entender a prática social, a catarse; e o quinto e último, ao nível de desenvolvimento atual do educando, isto é, a prática social final.

A escrita de participantes/mulheres do curso, que se apresenta no Quadro 1, expressa a passagem de uma visão caótica da realidade ao conhecimento científico proporcionado pelo projeto, onde se infere a realidade através de novas formas de pensar (Outras postagens podem ser conferidas em: Villela, 2014b). Trata-se da manifestação do aperfeiçoamento intelectual dos participantes, os quais, de forma contínua, se desafiam dialeticamente a transformar a contradição existente entre o velho (prática social inicial) e o novo (prática social final), conforme Gasparin (2013). A escrita presente nas postagens representa um dos pontos de chegada do processo pedagógico do projeto, comprovando que o processo de contra-hegemonia abre espaços de luta e deslocamentos e possibilita a reversão das formas de domínio material e imaterial (Cf. Moraes, 2002). A seguir as postagens de participantes/mulheres do curso. 


\section{Quadro 1 - Postagens sobre a história e saberes tradicionais das mulheres no território caipira}

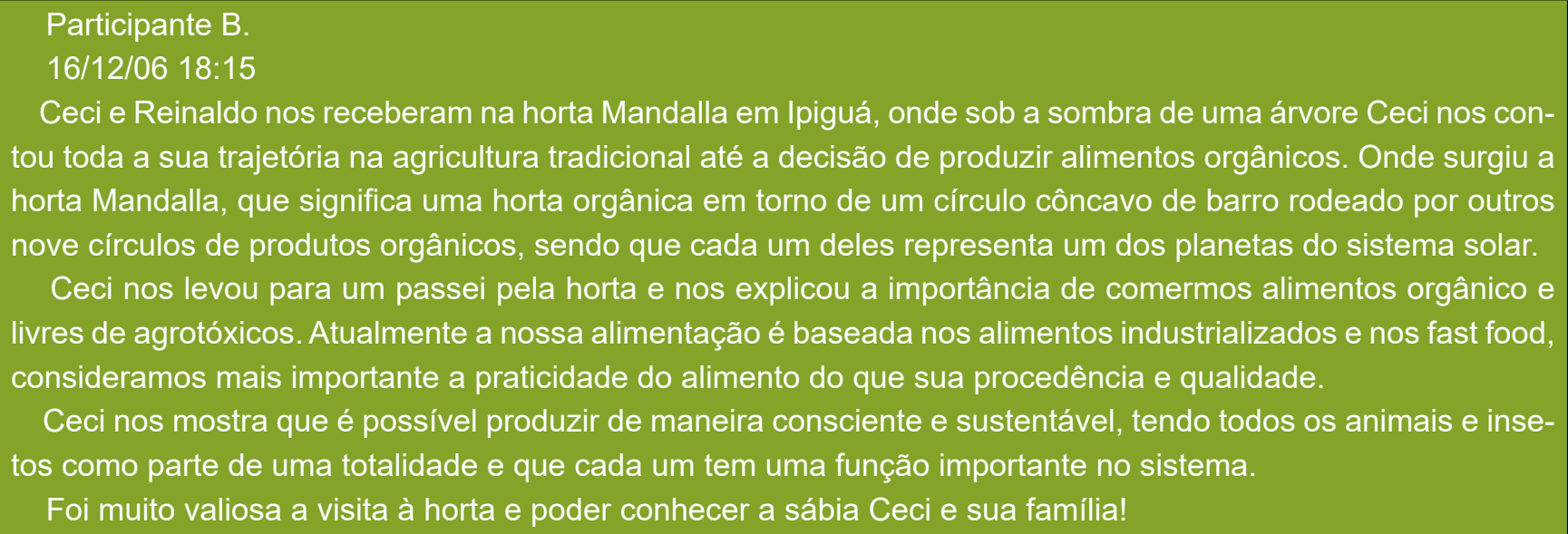

Ceci e Reinaldo nos receberam na horta Mandalla em Ipiguá, onde sob a sombra de uma árvore Ceci nos contou toda a sua trajetória na agricultura tradicional até a decisão de produzir alimentos orgânicos. Onde surgiu a horta Mandalla, que significa uma horta orgânica em torno de um círculo côncavo de barro rodeado por outros nove círculos de produtos orgânicos, sendo que cada um deles representa um dos planetas do sistema solar.

Ceci nos levou para um passei pela horta e nos explicou a importância de comermos alimentos orgânico e livres de agrotóxicos. Atualmente a nossa alimentação é baseada nos alimentos industrializados e nos fast food, consideramos mais importante a praticidade do alimento do que sua procedência e qualidade.

Ceci nos mostra que é possível produzir de maneira consciente e sustentável, tendo todos os animais e insetos como parte de uma totalidade e que cada um tem uma função importante no sistema.

Foi muito valiosa a visita à horta e poder conhecer a sábia Ceci e sua família!

\section{Participante M.}

\section{6/12/24 01:15}

Linda a história do milho contada pelo engenheiro agrônomo Oliver Blanco. A poesia no plantio dos três grãos; um para a terra, um para o espirito e um para o homem.

Nós, humanos, vivemos a separação da natureza como se fosse natural. Dentro de bolhas, observamos nosso habitat como objeto externo a nós. Criamos cidades, espaços habitáveis, que passam a falsa impressão de que estamos seguros, pra viver nossa cultura. Em nome dessa segurança fomos inventando maneiras de ficarmos cada vez mais seguros. Quando, no curso, ouvindo falar da composição mineral da terra, dos alimentos e dos animais, foi como que uma antiga memória que estava lá, escondida, começasse a emergir me tirando do automático. Dentro de nossas cidades, onde estão os espaços pra terra respirar? Onde estão os espaços pra sobrevivência de todos os seres que dividem o planeta conosco?

Nossa ligação com o solo vivo não é só uma questão de sobrevivência da espécie, mas nossa conexão com o universo através da terra.

O ultimo encontro, que era pra fechar o curso, abriu tantas possibilidades, que fiquei querendo mais.

\section{Participante J.}

\section{6/12/19 09:10}

Mais um encontro inspirador, onde aprendemos muito mais do que técnicas focadas sobre a cultura do milho, mas sim, estudos e experiências de Oliver Blanco e pesquisadores sobre manejos na agricultura orgânica.

Apesar de ser produtora e profissional da área, fui surpreendida com várias "novidades" como: a cromatografia aplicada à solos, plantas e compostagens; princípios $3 \mathrm{M}$ e 4M; sideróforos, biochar, peletização alternativa para sementes não convencionais, formulação de fosfito, dentre outras.

A experiência e a humildade de Oliver, fez-me com que eu mergulha-se no passado histórico do milho, passando por descobertas de técnicas, importância de um alimento orgânico para um organismo, impactos dos transgênicos, teoria da trofobiose e tantas outras coisas fantásticas sobre nosso tema.

Precisamos como toda certeza de um tempo a mais com Oliver para tentar "sugar" em todo bom sentido, mais de suas experiências e trazer para mais perto da nossa região tão "carente" informações imprescindíveis para a manutenção e ampliação da nossa agricultura familiar e orgânica.

Fonte: Villela (2016b).

Conforme podemos observar na escrita das participantes acima, a opção teórico-metodológica pela perspectiva da pedagogia histórico-crítica, contribui 
SABERES E EXPERIÊNCIAS DE PRATICAS PEDAGÓGICAS NO CONTEXTO EDUCACIONAL

para a valorização dos conhecimentos científico-culturais, base para a transformação da realidade. Conforme aponta Saviani (2012), a apropriação dos conhecimentos historicamente produzidos pela humanidade deriva do processo de mediação, em decorrência das relações das pessoas entre si e com a cultura. A escrita das participantes indica a superação do senso comum em direção à consciência filosófica. A escrita deixa transparecer que o educando reconhece elementos de sua situação, apontando a necessidade de intervir na realidade, transformando-a no sentido de ampliação da liberdade, da comunicação e colaboração entre os homens.

O mérito da reorganização das práticas sociais iniciais das participantes do curso está no processo didático da pedagogia histórico-crítica, cujo método de investigação e de elaboração do conhecimento científico tem por base o desvendamento da teoria do valor-trabalho de Marx. Esse aporte teórico-metodológico contribui para novas relações de ensino e aprendizagem e auxiliam tanto na formação dos alunos, quanto na dos professores. Um projeto de trabalho nessa perspectiva teórico-metodológica é um excelente instrumento didático, tendo em vista o processo dialético presente na sua metodologia de ensino e aprendizagem.

\section{CONCLUSÃO}

Podemos destacar como principais conquistas desse trabalho: (1) levantamento de material de pesquisa através de hipertextos produzidos, no ambiente do blog de aula, pelos participantes do projeto, de modo a propiciar dados qualitativos para pesquisas interessadas na descrição e compreensão da centralidade do valor-trabalho; (2) o desenvolvimento de possibilidades de ações, conforme demonstra a escrita das participantes, para a inclusão produtiva das mulheres do território caipira, segundo um projeto de trabalho na perspectiva da pedagogia histórico-crítica; (3) a consolidação de redes socioeconômicas da agricultura familiar no âmbito dos territórios rurais, especialmente da região noroeste paulista, considerando as práticas da economia solidária; (4) o fortalecimento de organi- 
SABERES E EXPERIÊNCIAS DE PRATICAS PEDAGÓGICAS NO CONTEXTO EDUCACIONAL

zações econômicas, contribuindo para a inclusão produtiva e para o desenvolvimento sustentável e solidário do território caipira.

Por fim, cabe destacar (5) a contribuição para a produção e sistematização de metodologias inovadoras de Educação de Jovens e Adultos (EJA). O projeto foi desenvolvido em um espaço de EJA, conforme Brasil (2000), onde esse ambiente engloba todo o processo de aprendizagem, formal ou informal, no qual pessoas consideradas adultas pela sociedade desenvolvem suas habilidades, enriquecem seu conhecimento e aperfeiçoam suas qualificações técnicas e profissionais, direcionando-as para a satisfação de suas necessidades e as de sua sociedade. No ambiente de EJA, as situações reais devem constituir o núcleo da organização da proposta pedagógica a ser desenvolvida. Para tanto, o desafio da EJA é integrar em sua organização curricular o trabalho e a elevação de escolaridade. A partir dessas ideias, o "arco ocupacional" trabalhado foi a produção rural familiar e a qualificação social e profissional. O resultado desse trabalho é a articulação dos saberes dos educandos com as diferentes áreas do conhecimento, possibilitando a vivência de novos valores, o desencadeamento de ações coletivas, bem como a elevação de escolaridade associada à qualificação social e profissional, possibilitando novas aprendizagens aos educandos, especialmente das mulheres do território caipira.

\section{REFERENNCIAS}

ANTUNES, Ricardo. Os sentidos do trabalho. Ensaio sobre a afirmação e a negação do trabalho. 1. ed. São Paulo: Boitempo, 1999.

BLANCO, Oliver H. N. Milho crioulo "Cunha". Blanco agricultura: consultoria e acompanhamento técnico para o envolvimento dialógico da agricultura orgânica no Brasil. Net, Araçatuba-SP, 2013. Disponível em: < http://oextensionista.blogspot.com.br/2013/05/milho-crioulo-cunha.html\#.VI6-hr9yzQ9 >. Acesso: 02 dez. 2015.

BRASIL. MINISTÉRIO DO MEIO AMBIENTE (MMA). Decreto $n^{\circ}$ 6.040, de 07 fev. Política Nacional de Desenvolvimento Sustentável dos Povos e Comunidades Tradicionais. Diário Oficial da União, Brasília, 08 fev. 2007. Disponível em: < 
http://www.mma.gov.br/desenvolvimento-rural/terras-ind\%C3\%ADgenas,-povos-e-comunidades-tradicionais >. Acesso em: 15 mai 2013.

BRASIL. Conselho Nacional de Educação/Câmara de Educação Básica. Diretrizes Curriculares Nacionais para a Educação de Jovens e Adultos. Parecer $\mathrm{n}^{\circ} 11$ aprovado em 10 de maio de 2000.

CAMPOS, A. V. de. Milho crioulo: sementes de vida - pesquisa, melhoramento e propriedade intelectual. Rio Grande do Sul: Editora da Universidade Regional Integrada do Alto Uruguai e das Missões - URI, 2007.

DANTAS, Vanda M. C. S. Educação dos pescadores: saberes formais na educação de jovens e adultos versus tradicionais nas comunidades. Interfaces Científicas - Educação, Aracaju, v.1, n. 2, p. 53-60, fev. 2013.

Nas marés da vida: histórias e saberes das mulheres marisqueiras em Natal - RN. 2010. Dissertação (Mestrado em Ciências Sociais). Orientadora: Profa. Dra. Maria da Conceição Xavier de Almeida. Programa de Pesquisa e Pós-Graduação em Ciências Sociais, Universidade Federal do Rio Grande do Norte.

DIEGUES, Antonio C. (Org.). Saberes tradicionais e biodiversidade no Brasil. Brasília: Ministério do Meio Ambiente; São Paulo: USP, 1999.

FLORES, Letícia. Horta Mandalla de Ipiguá - SP. Net, São José do Rio Preto SP, 2016. Disponível em: < https://awebic.com/cultura/horta-organica/ >. Acesso em 20 jan. 2016.

GARCIA, Paula H. da C. Acupuntura ecoturística em área de proteção ambiental: o caso de Guaraqueçaba, Paraná. São Paulo: Annablume, 2012.

GASPARIN, João L. Uma didática para a pedagogia histórico-crítica. 5. ed. rev. Campinas: Autores Associados, 2013.

GERALDO, Antonio Carlos H. Didática de ciências naturais na perspectiva histórico-crítica. São Paulo: Autores Associados, 2009.

HERNÁNDEZ, F.; RODRIGUES, J. H. Transgressão e mudança na educação: os projetos de trabalho. Porto Alegre: Artmed, 1998.

HOLANDA, Sérgio B. Caminhos e fronteiras. 3. ed. São Paulo: Companhia das Letras, 1995. 
KASPCHAK, M.; GASPARIN, J. L. Projeto de trabalho docente-discente: uma expressão da práxis. Seminário de Pesquisa do PPE, Universidade Estadual de Maringá. Net, Maringá, 2013. Disponível em: < http://www.ppe.uem.br/publicacoes/seminario_ppe_2013/trabalhos/co_02/62.pdf >. Acesso em 02 dez. 2015.

KOMESU, Fabiana C.; TENANI, Luciani E. Práticas de letramento/escrita em contexto da tecnologia digital. Eutomia (Recife), v. 1, p. 1-15, 2010.

LERNER, Jaime. Acupuntura urbana. 1. ed. Rio de Janeiro: Record, 2003.

MARINS, P. C. G. A vida cotidiana dos paulistas: moradias, alimentação, indumentária. In: SETUBAL, Maria Alice (Org.). Modos de vida dos paulistas: identidades, famílias e espaços domésticos. São Paulo: Centro de Estudos e Pesquisas em Educação, Cultura e Ação Comunitária / CENPEC, Imprensa Oficial do Estado de São Paulo, 2004. v. 2. p. 1-3.

MARSIGLIA, Ana Carolina Galvão. A prática pedagógica histórico-crítica na educação infantil e ensino fundamental. Campinas: Autores Associados, 2011.

MORAES, Dênis de. Imaginário social e hegemonia cultural. Website Gramsci e o Brasil. Net, Rio de Janeiro, 2002. Disponível em: < http://www.acessa.com/ gramsci/?page=visualizar\&id=297 >. Acesso em 26 jan. 2017.

NOROESTE Paulista. In: Wikipédia: a enciclopédia livre. Disponível em: < http://pt.wikipedia.org/wiki/Noroeste_Paulista > Acesso em: 12 ago 2014.

SANTOS, C. R. A. dos. A comida como lugar de história: as dimensões do gosto. História: Questões \& Debates, Curitiba, n. 54, p. 103-124, jan./jun. 2011.

SANTOS, César Sátiro. Ensino de ciências: abordagem histórico-crítica. Campinas: Autores Associados, 2005.

SCALCON. Suze Gomes. À procura da unidade psicopedagógica: articulando a psicologia histórico-cultural com a pedagogia histórico-crítica. Campinas: Autores Associados, 2002.

SAVIANI, Dermeval. Pedagogia histórico-crítica: primeiras aproximações. 11. ed. rev. reimpr. Campinas: Autores Associados, 2012. (Coleção Educação Contemporânea). 
. Marxismo e pedagogia. Intervenção na Mesa IV - Teoria Marxista e Pedagogia Socialista, integrante da programação do III EBEM (Encontro Brasileiro de Educação e Marxismo). Salvador, 14 de novembro de 2007. Revista HISTEDBR On-line, Campinas, número especial, p. 16-27, abr. 2011. Disponível em: < http:// www.histedbr.fe.unicamp.br/revista/edicoes/41e/art02_41e.pdf >. Acesso em 21 jan. 2017.

. Trabalho e educação: fundamentos ontológicos e históricos. Revista Brasileira de Educação, Campinas, v. 12, n. 34, jan/abr. 2007, p. 152-165.

- O choque teórico da Politecnia. Revista Trabalho, Educação e Saúde, Rio de Janeiro, v. 1, n. 1, p. 131-152, Mar. 2003. Disponível em: < http://www.scielo.br/ scielo.php?script=sci_arttext\&pid=S1981-77462003000100010\&lng=en\&nrm=iso >. Acesso em: 22 Jan. 2017.

VILLELA, F. F.; TENANI, L. E.; SILVA, C. L. F. da. O Programa Unesp de Educação de Jovens e Adultos. In: AZEREDO-OLIVEIRA, M. T. V. de. Livro de resumos dos projetos de extensão do câmpus de São José do Rio Preto (UNESPI IBILCE). São José do Rio Preto: UNESP - Campus de São José do Rio Preto, 2014.

VILLELA, Fábio Fernandes. Cultura ambiental no território caipira: história e saberes tradicionais das mulheres do noroeste paulista. Retratos de Assentamentos. v. 19, p. 323 - 350, 2016a. Disponível em: < http://www.uniara.com.br/nupedor/revista-retratos/ >. Acesso em 21 jan. 2017.

. Território caipira: uma civilização do milho. Curso de Extensão Universitária. Pró-Reitoria de Extensão da Unesp - Proex. Net, São José do Rio Preto - SP, 2016b. Disponível em: < http://www.cecmundorural.com.br/ >. Acesso em 23 jan. 2017.

. A formação de professores de educação de jovens e adultos no PEJA-Rio Preto: um caleidoscópio de possibilidades. Cadernos da Pedagogia (Ufscar. Online). v.9, p.2-15, 2016c. Disponível em: < http://www.cadernosdapedagogia. ufscar.br/index.php/cp/article/viewFile/862/307 >. Acesso em 25 jan. 2017.

As cidades do intelecto coletivo: a indústria da construção civil, suas novas tecnologias e modos de socialização In: ANTUNES, Ricardo (Org.). Riqueza e miséria do trabalho no Brasil III. 1 ed. São Paulo: Boitempo Editorial, 2014a, v. III, p. 141-161. 
. Centro virtual de estudos e culturas do mundo rural. Projeto de Extensão Universitária. Pró-Reitoria de Extensão da Unesp - Proex. Net, São José do Rio Preto - SP, 2014b. Disponível em: < http://www.cecmundorural.com.br/ >. Acesso em 27 fev. 2015.

Indústria da construção civil e reestruturação produtiva: as novas tecnologias e seus modos de socialização construindo as cidades contemporâneas. São Paulo: Livrus, 2013. ePUB disponível em: < www.livrus.com.br >. Acesso em 21 jan. 2017.

. et al. $1^{\circ}$ Encontro de Agroecologia de São José do Rio Preto e Região e a $4^{\text {a }}$ Feira Estadual de Saberes, Sabores e Sementes. 2013. Organização de Evento. Site do evento disponível em: < http://www.raisp.com.br/ >. Acesso em 01 jul 2014.

. Práticas educativas comparadas em educação do campo e os desafios da formação omnilateral na América Latina. Revista Nera, Ano 14, n. 19, Jul./ Dez. 2011. Disponível em: < http://revista.fct.unesp.br/index.php/nera/article/ view/1802 >. Acesso em 26 jan. 2017.

et al. O Programa Unesp de Educação de Jovens e Adultos - PEJA UNESP. Projeto de Extensão Universitária. Net, São José do Rio Preto - SP, 2007. Disponível em: < https://www.youtube.com/watch?v=FiHsDxnsO7Y >. Acesso em 25 jan. 2021. 


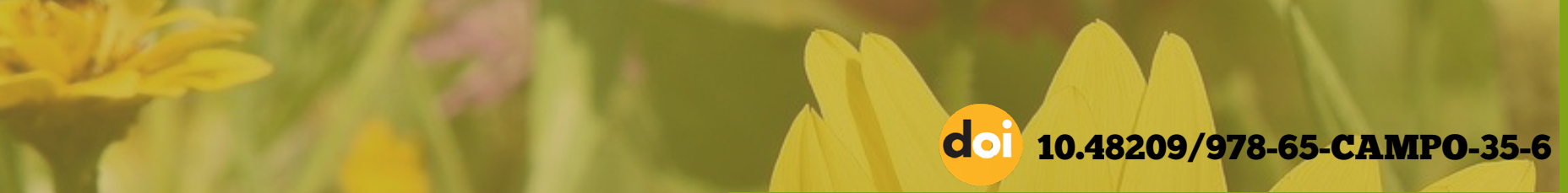

\section{CAPITULO 6}

UM OMHAR SOBRE

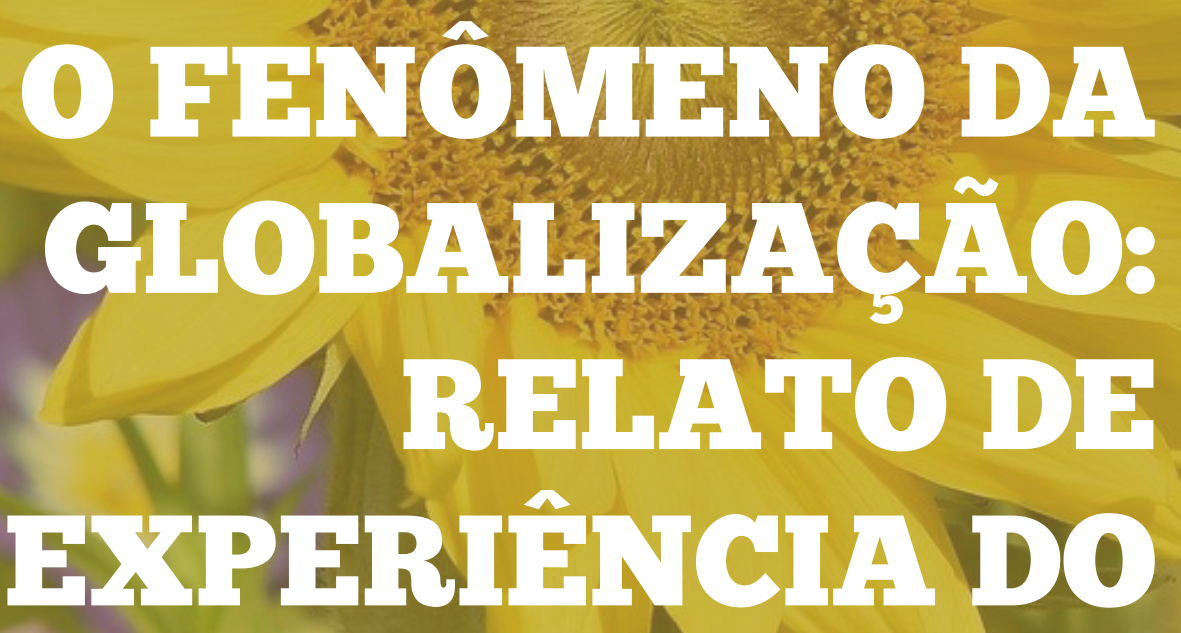
PROGRAMARESIDENCIA PEDAGógICA Na BSCOLA DO CAMPO EM SUMIE-PB

Alisson Clauber Mendes de Alencar

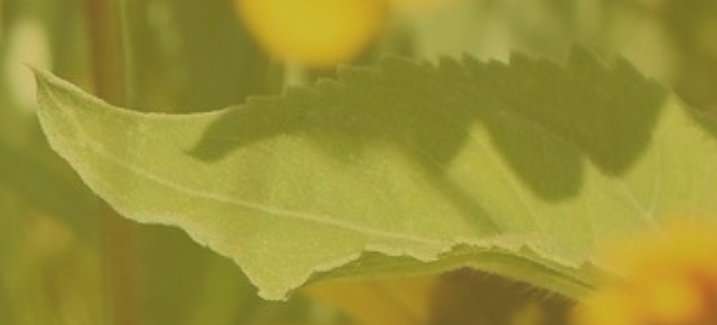

Denise Xavier Torres 
SABERES E EXPERIÊNCIAS DE PRÁTICAS PEDAGÓGICAS NO CONTEXTO EDUCACIONAL

\section{INTRODUÇÃ}

O presente estudo intitulado "Relato de experiência do Programa Residência Pedagógica na Escola do Campo José Bonifácio Barbosa de Andrade em Sumé - PB: um olhar sobre o fenômeno da Globalização" surgiu da necessidade de construir uma articulação entre o que é proposto nos momentos de planejamento no espaço da universidade e o que se elabora nas escolas da educação básica via sujeitos protagonistas dos processos do desenvolvimento educativo.

Dentre estes ressaltamos estudantes das licenciaturas/residentes e das escolas públicas, docentes das escolas públicas e da universidade e os profissionais que compõem os trabalhadores do campo educativo (gestoras/es, coordenadoras/es e supervisoras/es).

A referida proposta educativa está assentada na perspectiva freireana de pensar-fazer a educação. De acordo com Freire (1987) faz-se necessário construir e promover transformações sociais nos espaço educativos, tendo como protagonistas desta ação, os sujeitos envolvidos no transcurso do processo. Tivemos como lócus de atuação, para o desenvolvimento da ação educativa, a Unidade Municipal de Educação Infantil Ensino Fundamental José Bonifácio Barbosa de Andrade, escola do campo situada na zona rural do município de Sumé, Cariri Ocidental paraibano, Mesorregião da Borborema.

No que concerne aos sujeitos participativos destacamos a equipe gestora da instituição, o professor regente da área de Ciências Humanas e Sociais e os estudantes do $8^{\circ}$ ano do ensino fundamental e a orientadora institucional do Programa Residência Pedagógica, esta que estava com a incumbência de realizar a mediação entre universidade e a escola.

Direcionamos como objetivos deste relato de experiência: a) Estreitar os vínculos entre a universidade e as escolas da educação básica; b) Construir uma proposta metodológica e pedagógica onde fosse utilizada as Tecnologias da Informação e Comunicação (TIC) como recurso didático durante as aulas de Ciências Humanas e Sociais, com os estudantes do $8^{\circ}$ ano, da escola do campo, durante 
o ensino remoto e c) Promover um momento avaliativo (com os discentes) após desenvolvimento da atividade, para analisar a proposta pela ótica do estudante da educação básica.

No tocante às concepções teóricas desta pesquisa, nos apoiamos nos dizeres de Nóvoa (2009), onde o mesmo ressalta que para a formação docente acontecer é necessário que ocorra o exercício da profissão no cotidiano escolar. Ressaltamos aqui, que pelo fato da instituição de ensino está desenvolvendo suas atividades através de plataformas digitais, entendemos ser necessária a realizar adequações a nossa práxis pedagógica, para que ocorra uma aproximação significativa entre universidade e a escola. Potencializando assim, os processos formativos.

Destacamos aqui o entendimento de Kenski (2010) que ressalta a importância da apropriação dos recursos tecnológicos nos processos de ensino e aprendizagem para ampliar condições de mediação nos espaços educativos.

Direcionamos também, nosso arcabouço teórico sobre o que aborda o Perrenoud (2002) em relação a sua preocupação para que os professores não se tornem meros executores ou operacionalizadores de atividades, assim esse teórico promove uma reflexão na prática educativa ampliando os olhares docentes, e relacionando estes aos problemas que podem ser enfrentados no espaço escolar.

Torna-se imprescindível, em todo e qualquer estudo, compreendermos o fator da excepcionalidade, pois que estamos construindo análises, reflexões e propostas didático-pedagógicas no período da pandemia do Coronavírus (COVID-19), logo toda cautela nos nossos dizeres, saberes e fazeres é necessária.

\section{DESENVOLVIMENTO}

As inquietações e provocações que este estudo vem a promover versam sobre o que foi vivenciado e o que foi construído durante as nossas práticas 
SABERES E EXPERIÊNCIAS DE PRATICAS PEDAGÓGICAS NO CONTEXTO EDUCACIONAL

na condição de Residentes do Programa Residência Pedagógica - PRP, bem como de nossa posição de discente do Curso de Licenciatura Interdisciplinar em Educação do Campo da Universidade Federal de Campina Grande - UFCG/ CDSA.

Saviani (2009, p. 151) afirma que são fundamentais todas as iniciativas que ampliem a possibilidade do estudante de graduação vivenciar "o ato docente como fenômeno concreto", bem como explícito nos dizeres de Nóvoa (2009) dimensionar o "exercício da profissão". Assim sendo, tais autores asseguram que durante o percurso formativo, é imprescindível o contato com o espaço escolar.

O PRP, além de ampliar nossa concepção em relação aos aspectos teóricos e práticos da educação, possibilitou também a aproximação do licenciado a uma escola que atua por área de conhecimento, onde a interdisciplinaridade está intrínseca na proposta pedagógica da instituição, logo, realizamos nossas análises na área das Ciências Humanas e Sociais, acompanhados pelo professor regente.

Para se construir articulações teóricas e metodológicas neste campo do saber, e de modo particular entre os componentes curriculares de História e Geografia, é fundamental tecermos comentários sobre como a interdisciplinaridade pode acontecer. Barros (2010) ressalta que a interdisciplinaridade entre a história e a geografia é estabelecida para além do conceito de espaço, onde podem se destacar noções referentes tanto aos territórios, quanto às regiões, e a partir destes fios condutores estabelecem-se reflexões em múltiplas escalas.

Construir uma proposta metodológica que envolve os componentes curriculares de História e Geografia, que são da área das Ciências Humanas e Sociais (CHS), não se caracteriza como tarefa das mais simples. Porém, são campos de saberes que dialogam fortemente com questões referentes aos grupos sociais, em suas especificidades temporais e espaciais, sendo estes dois últimos fatores, os elementos essenciais para a constituição de uma interdisciplinaridade significativa. 
SABERES E EXPERIÊNCIAS DE PRATICAS PEDAGÓGICAS NO CONTEXTO EDUCACIONAL

As referidas disciplinas possuem, eminentemente, um caráter positivista e descritivo, fato este, em décadas passadas amplamente difundido através de uma perspectiva de ensino tradicional, sobretudo no contexto brasileiro.

Ao estabelecermos uma conexão com a prática pedagógica docente que outrora estava centrada no professor como transmissor de saber e do estudante, na condição de elemento receptor, como descreve Schmidt e Cainelli (2009) que ressaltam que esta perspectiva pedagógica foi bastante difundida nos bancos escolares brasileiros.

A proposta da escola José Bonifácio Barbosa de Andrade, está assentada num currículo integrado por área de conhecimento, que se baseia na articulação e inter-relação dos componentes, das áreas, dos sujeitos e do lugar onde estes vivem. Tal currículo é compreendido como um processo que articula os saberes científicos e os saberes dos sujeitos e das famílias, tendo como referência a formação humana e a Convivência no Semiárido Brasileiro.

A perspectiva de trabalhar com projetos curriculares envolvendo disciplinas diferentes, eixos temáticos ou temas geradores integrados favorece a "coletividade", uma vez que os profissionais da educação envolvidos no processo tornam-se partícipes, articulando-se em torno de metas comuns a serem encaradas de maneira cooperativa e responsável frente ao grupo. Caracteriza-se como um desafio, pois envolve múltiplos saberes e requer um planejamento atento, dinâmico e flexível.

De acordo com tal perspectiva aproximamo-nos de Sacristán (1999) quando ressalta que a relação de determinação sociedade-cultura-currículo-prática explica que faz-se necessário revitalizar os currículos nos sistemas educativos.

Fundamentamos este trabalho numa concepção de pesquisa aplicada por possuir o desenvolvimento de conhecimentos que se construíram de modo prático e aplicado numa vertente qualitativa. Conduzimos nossas análises metodológicas a partir das palavras de Lüdke e André (2013), onde ressaltam que não é a perspectiva do nome que estabelece na pesquisa rigorosidade metodológica, o 
SABERES E EXPERIÊNCIAS DE PRATICAS PEDAGÓGICAS NO CONTEXTO EDUCACIONAL

que possui maior significância é a explicação, pormenorizada, do itinerário trilhado para alcançar os objetivos, ressaltando a justificativa de cada opção realizada.

A proposta pedagógica foi desenvolvida na Unidade Municipal de Educação Infantil e Ensino Fundamental José Bonifácio Barbosa de Andrade, escola do campo, situada no Distrito de Pio $\mathrm{X}$, na zona rural do município de Sumé, microrregião do Cariri Ocidental paraibano, fundada no ano de 2013, é uma instituição de ensino que oferta as etapas da educação infantil, anos iniciais e finais do ensino fundamental às crianças e adolescentes de treze comunidades rurais localizadas nas imediações daquele distrito.

\section{RESULTADOS E DISCUSSÃO}

A atividade foi desenvolvida ao final do mês de agosto do corrente ano, através dos planejamentos realizados sistematicamente entre o residente e o professor regente. Construímos uma atividade onde o recurso metodológico utilizado foi o uso das Tecnologias da Informação e Comunicação (TIC). Durante os diálogos realizados com o professor do componente curricular de ciências humanas e sociais, entendemos que a proposta seria mais interessante de ser desenvolvida com os estudantes do $8^{\circ}$ ano, pelo fato de ocorrer uma maior interatividade dos mesmos durante as aulas.

No decorrer dos planejamentos e já de posse do plano de ensino referente ao $2^{\circ}$ bimestre, sabíamos que o eixo direcionador da atividade estava articulado com a temática "IDENTIDADE, TRABALHO, POPULAÇÃO E GLOBALIZAÇÃO: como os sujeitos se situam no tempo e no espaço", logo, montamos nossa atividade abordando os seguintes aspectos temáticos: Geografia, problemas sociais, tecnologias, globalização e Cultura no município de Sumé. A atividade foi desenvolvida no dia 16 de agosto, porém idealizada e planejada desde meados de julho, junto com o professor regente.

Em relação às etapas de sistematização da atividade desenvolvida, apresentaremos a sequência didático-pedagógica e descreveremos os procedimentos metodológicos utilizados para consecução da atividade projetada. 
SABERES E EXPERIÊNCIAS DE PRATICAS PEDAGÓGICAS NO CONTEXTO EDUCACIONAL

ETAPA 01 - Discussão da proposta didática com o professor regente.

A partir do momento que estávamos de posse do plano bimestral de aulas para o componente curricular de ciências humanas e sociais, fomos dialogando com o professor regente sobre quais as possíveis temáticas que poderíamos estar abordando durante nosso momento de intervenção junto aos estudantes do $8^{\circ}$ ano da Escola José Bonifácio Barbosa de Andrade.

No decorrer de nossos diálogos, elencamos tópicos para montarmos nossa atividade, onde dentre estes destacamos: Geografia, problemas sociais, tecnologias, globalização e Cultura no município de Sumé. Mas durante o desenvolvimento da atividade e junto aos estudantes, analisamos os referidos temas em escalas estadual, regional, nacional e global, para ampliação do entendimento dos estudantes e aproximar, também, os temas da realidade e das vivências dos mesmos.

\section{ETAPA 02 - Levantamento das temáticas abordadas.}

O município de Sumé - PB, desde o ano de 2020, adotou uma proposta pedagógica, via Secretaria de Educação - SEDUC, para que em cada bimestre sejam desenvolvidas atividades que possuam um eixo temático estruturante. Assim, toda a rede municipal durante cada bimestre constrói e desenvolve propostas pedagógicas de acordo com uma temática pré-estabelecida.

No $2^{\circ}$ bimestre, o eixo temático construído e adaptado para nossa mediação foi "IDENTIDADE, TRABALHO, POPULAÇÃO E GLOBALIZAÇÃO: como os sujeitos se situam no tempo e no espaço", e a partir deste eixo temático, nós (residentes) junto com o professor regente, elaboramos os tópicos que iriam fazer parte da nossa proposta de atividade.

\section{ETAPA 03 - Instrumentos metodológicos na realização da atividade.}

Previamente dialogamos com o professor regente para utilização do grupo do WhatsApp da turma do $8^{\circ}$ ano, para socializar os temas e a data da aula. Em seguida montamos um PowerPoint exemplificando os processos, etapas e características da Globalização e seus impactos em nossa vida, no nosso cotidiano. 
Abordando as temáticas pré-estabelecidas através do PowerPoint;

\section{ETAPA 04 - Construção da atividade "Diálogos sobre o fenômeno da Globalização" pelos discentes do $8^{\circ}$ ano.}

Os estudantes da turma do $8^{\circ}$ ano da Escola José Bonifácio Barbosa de Andrade, estavam de posse, previamente de um arquivo em PDF com os temas que seriam abordados durante nossa aula. Ao iniciarmos a exposição do material em PDF pelo Google Meet (plataforma digital utilizada na rede municipal de educação de Sumé para realização de atividades síncronas durante o ensino remoto), os estudantes argumentaram que sobre vários daqueles temas eles já possuíam conhecimentos.

Ao iniciarmos a apresentação do PowerPoint, fizemos uma explanação sobre o conceito de Globalização e suas principais características, onde cada estudante teve oportunidade de expressar suas ideias e tirar dúvidas no decorrer das explicações. Nos últimos slides do PowerPoint apresentamos exemplos dos impactos da Globalização nos territórios e nas vidas das pessoas. Expomos uma sequência de imagens, desde a escola, passando por um ponto turístico do município de Sumé e uma última imagem apresentando variados pontos turísticos do mundo.

ETAPA 05 - Apresentação e discussão sobre as imagens inerentes ao fenômeno da Globalização pelos discentes do $8^{\circ}$ ano.

No transcurso da atividade e após as explicações necessárias para a construção dos entendimentos, foi solicitado aos discentes que os mesmos construíssem seus argumentos para explicar os processos e fenômenos da Globalização, bem como seus impactos no município de Sumé e nos espaços campesinos deste território.

Enquanto os estudantes estavam debatendo, nós estávamos revisando os conteúdos discutidos e tirando as dúvidas referentes aos termos inerentes ao processo de Globalização. Noutras palavras, estávamos realizando um apanhado teórico dos assuntos estudados. 
ETAPA 06 - Avaliação da atividade "Diálogos sobre o fenômeno da Globalização" pelos discentes do $8^{\circ}$ ano da Escola José Bonifácio Barbosa de Andrade.

No tocante ao momento avaliativo da atividade, os discentes informaram que atividade foi dinâmica e interessante, mas que o tempo para construção dos argumentos (que havia sido estipulado apenas 5 minutos) poderia ter sido maior. Destacou-se também, a importância de termos apresentado o vídeo da música " $3^{a}$ do Plural", da Banda Engenheiros do Hawaii, para ilustrar múltiplos processos e fenômenos da Globalização.

ETAPA 07 - Análise e avaliação da atividade "Diálogos sobre o fenômeno da Globalização” pelo Residente e pelo Professor Regente.

Primeiramente gostaríamos de destacar que foi uma atividade realizada em caráter de excepcionalidade, já que para sua efetivação faz-se necessário à utilização de aparelhos celulares conectados à internet (no caso dos estudantes) e no nosso caso, na condição de residente mediador da proposta de atividade, é imprescindível o uso do computador e do celular, ambos conectado à internet. E, somos sabedor que nem todos os estudantes possuem acesso diário à internet, sendo essa uma característica muito presente nas escolas do campo no território de Sumé.

Percebemos que a interação dos estudantes do $8^{\circ}$ ano, no transcurso das aulas do componente curricular de Ciências Humanas e Sociais foi potencializada a partir das metodologias utilizadas durante as regências realizadas. É fundamental que haja uma ampla articulação entre o recurso metodológico, os conteúdos e uma possibilidade efetiva de interconexão destes segmentos.

Destacamos ainda, que a atividade "Diálogos sobre o fenômeno da Globalização" possuiu um caráter colaborativo e não um caráter competitivo, isso potencializa a interação entre os discentes, favorecendo e ampliando as concepções de solidariedade, que em nosso entendimento, devem ser constantes seja em sala de aula e/ou em sociedade. 
Figura 01 - Apresentação da temática.

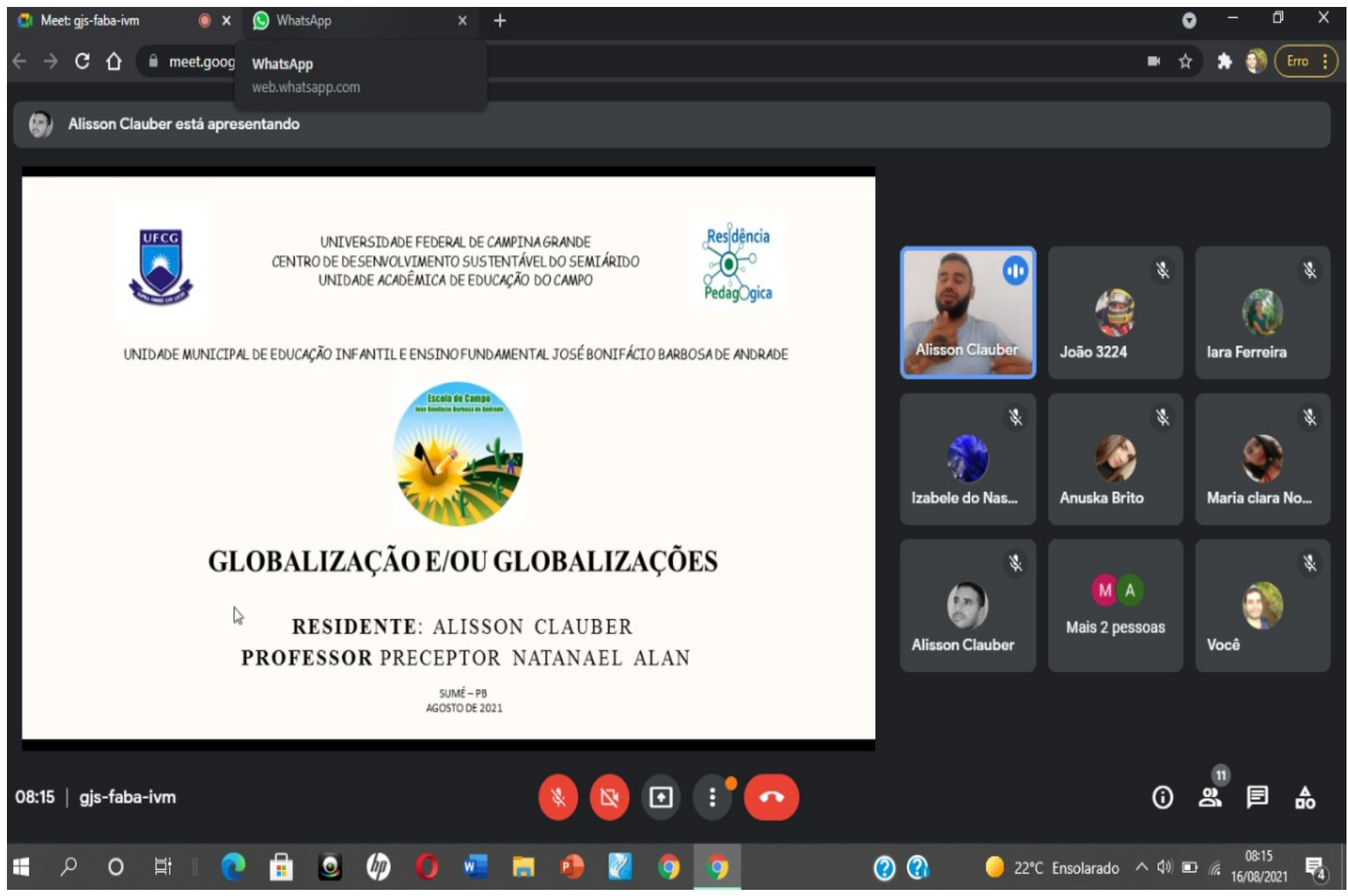

Fonte: Acervo do autor, 2021.

Figura 02 - Exposição de imagens para discutir o conceito de Globalização.
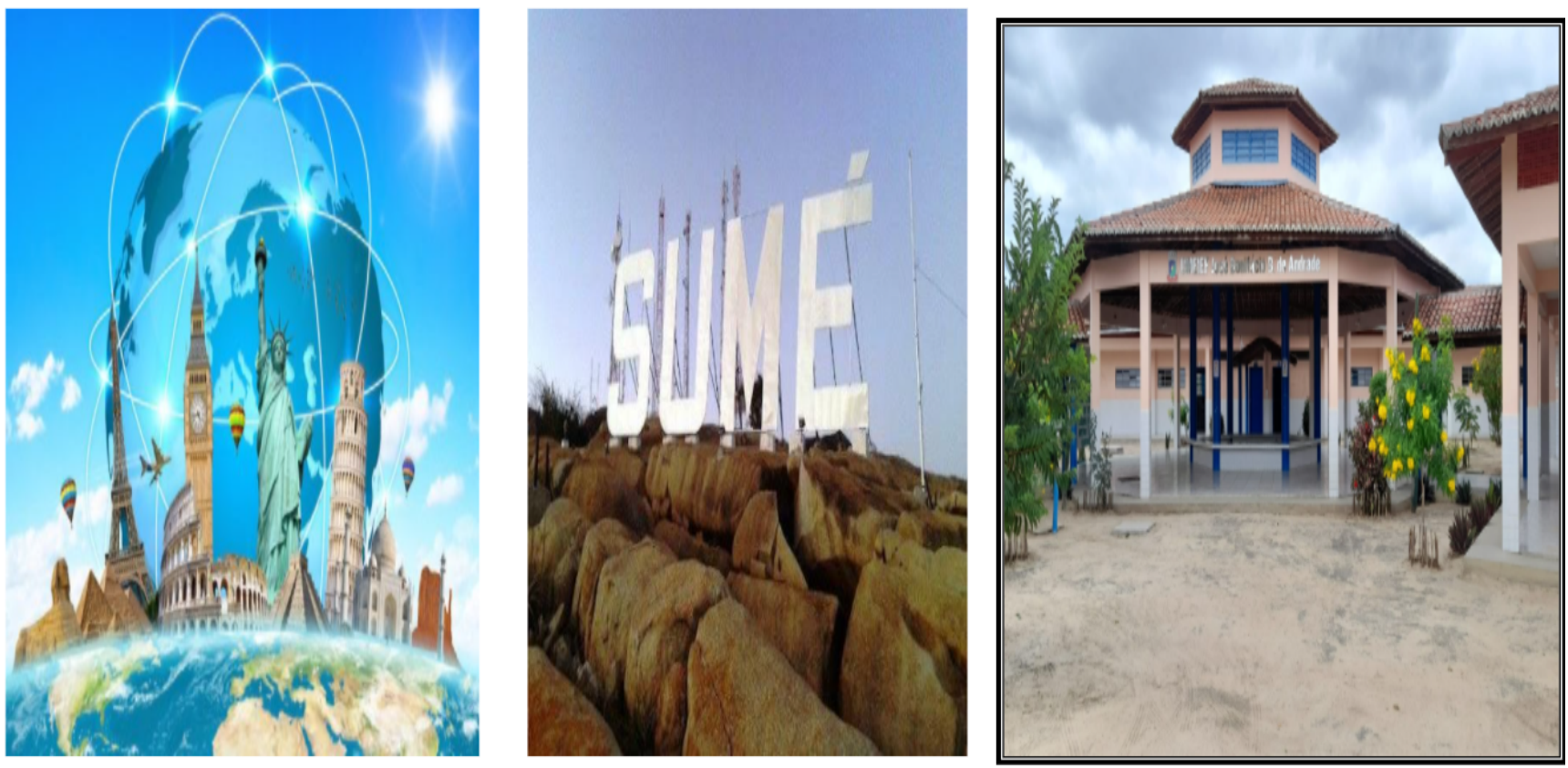

Fonte: Acervo do autor, 2021. 
SABERES E EXPERIÊNCIAS DE PRÁTICAS PEDAGÓGICAS NO CONTEXTO EDUCACIONAL

Em relação utilização da estratégia pedagógica do mapeamento conceitual, Moreira e Buchweitz (1993) discorrem que esta é uma técnica muito flexível e em razão disso pode ser usado em diversas situações, para diferentes finalidades: instrumento de análise, didática, recurso de aprendizagem e meio de avaliação.

Percebemos que durante o desenvolvimento da atividade proposta estruturada a partir da argumentação, os estudantes conseguiram sistematizar suas ideias de acordo com tópicos hierárquicos, construindo assim uma sequência lógica e processual a partir das temáticas propostas, fato este que avaliamos o referido momento pedagógico de forma positiva e com potencial de ampliar e dinamizar o raciocínio do estudante, através da mediação docente.

No atual contexto educacional, faz-se necessário rever nossas práticas educativas que são desenvolvidas no chão ou nos territórios virtuais das escolas, e consequentemente as implicações destas para a formação de indivíduos mais conscientes de suas ações.

É imprescindível uma reconfiguração nas concepções que atentam para as diretrizes postas para escola, no que concerne a introdução dos recursos tecnológicos no ambiente escolar e valorização das identidades discentes e docentes, pois como afirma Cavalcanti (2002) a experiência do cotidiano da escola é um elemento importantíssimo para a compreensão da formação do professor, já que sua identidade deve ser, também, construída e reconstruída nesse espaço, que é por excelência seu lugar, seu chão.

\section{CONCLUSÃO}

Nos escritos de Marcelo Garcia (1992) o referido autor traz à tona e explica o termo 'continuum' na formação docente, destacando que esse princípio implica a necessidade da construção significativa entre a interconexão da formação inicial e a formação permanente dos professores, onde se faz necessário compreender, também, o currículo. 
SABERES E EXPERIÊNCIAS DE PRATICAS PEDAGÓGICAS NO CONTEXTO EDUCACIONAL

Construir uma proposta didático-pedagógica em uma escola situada na zona rural, ou seja, uma escola com a identidade do campo, no contexto de ensino remoto, não é tarefa das mais fáceis, mesmo assim, acreditamos que realizamos um trabalho respeitando, o currículo o território e os sujeitos protagonistas deste processo.

O PRP potencializa as conexões entre a universidade e as escolas da Educação Básica, ampliando as concepções formativas dos futuros educadores e dos professores regentes. Acreditamos que é imprescindível, no contexto em que nos encontramos, ampliar nossas capacidades e qualidades didáticas.

Este estudo se caracteriza como um reflexo do que pode ser construído entre instituições, a partir do momento em que os profissionais envolvidos no processo teórico e prático estejam em sincronismo com as reais necessidades dos estudantes, sendo tal fator um elemento primordial que todo educador necessita estar atento.

O Programa Residência Pedagógica, nos fez perceber outras possibilidades de atuação em nossa formação que não necessariamente está relacionada à sala de aula tradicional, mas percebemos que é tão importante quanto.

Compreender as especificidades do contexto educativo e trabalhar para atender demandas da realidade do discente da educação básica, no período de ensino remoto, desperta um olhar atento para as reais necessidades, anseios e perspectivas dos sujeitos com quem estamos interagindo.

Os momentos na universidade, de discussão e debates com os textos e os momentos na escola, remotamente, nos fizeram perceber o quão é fundamental se estabelecer as relações entre teorias e práticas a chamada práxis freireana, no espaço onde estamos atuando, ampliando nossa percepção e nossos entendimentos sobre a docente.

Discorremos, ainda que, não adianta inovar eminentemente os processos educativos com a inserção de recursos tecnológicos, se a didática e a práxis 
docente permanecer reacionária e distante da realidade discente. Fazem-se necessárias mudanças de posturas frente às novas demandas emanadas da sociedade e que adentraram o espaço escolar, contextualizar é preciso.

\section{REFERENCIAS}

BARROS, José D’Assunção. Geografia e História: uma interdisciplinaridade mediada pelo espaço. Geografia (Londrina) v. 19 n. 3, 2010.

CAVALCANTI, Lana de Souza. Geografia e práticas de ensino. Goiânia: Alternativa, 2002.

FREIRE, Paulo. Pedagogia do oprimido. Rio de Janeiro: Paz e Terra, 1987.

KENSKI, Vani Moreira. Educação e Tecnologias: o novo ritmo da informação. 6.ed. Campinas: Papirus, 2010.

LÜDKE, Menga. ANDRÉ, Marli E. D. A. de. A Pesquisa em educação: abordagens qualitativas. $2^{\mathrm{a}}$ ed. Rio de Janeiro: E.P.U., 2013.

MARCELO GARCIA, Carlos. A formação de professores: novas perspectivas baseadas na investigação sobre o pensamento do professor. In: NÓVOA, Antônio. (Coord.). Os professores e sua formação. Lisboa: Publicações Dom Quixote, 1992.

MOREIRA, M.A. e BUCHWEITZ, B. Novas estratégias de ensino e aprendizagem: os mapas conceituais e o Vê epistemológico. Lisboa: Plátano Edições Técnicas, 1993.

NÓVOA, António. Imagens do futuro presente. Lisboa: Educa, 2009.

PERRENOUD, Philippe. A prática reflexiva no ofício de professor: profissionalização e razão pedagógica. Porto Alegre: Artmed, 2002.

SACRISTÁN, José Gimeno. Poderes instáveis em educação. Porto Alegre: Artmed, 1999. 
SAVIANI, D. Formação de professores: aspectos históricos e teóricos do problema no contexto brasileiro. Revista Brasileira de Educação, Belo Horizonte, v. 14, n. 40, p. 143-155, jan./abr. 2009. Disponível em: <https://www. scielo.br/pdf/rbedu/v14n40/v14n40a12.pdf>.

Acesso em: 10 jul. 2021.

SCHMIDT, Maria Auxiliadora. CAINELLI, Marlene. Ensinar História. 2 ed. São Paulo: Scipione, 2009. 


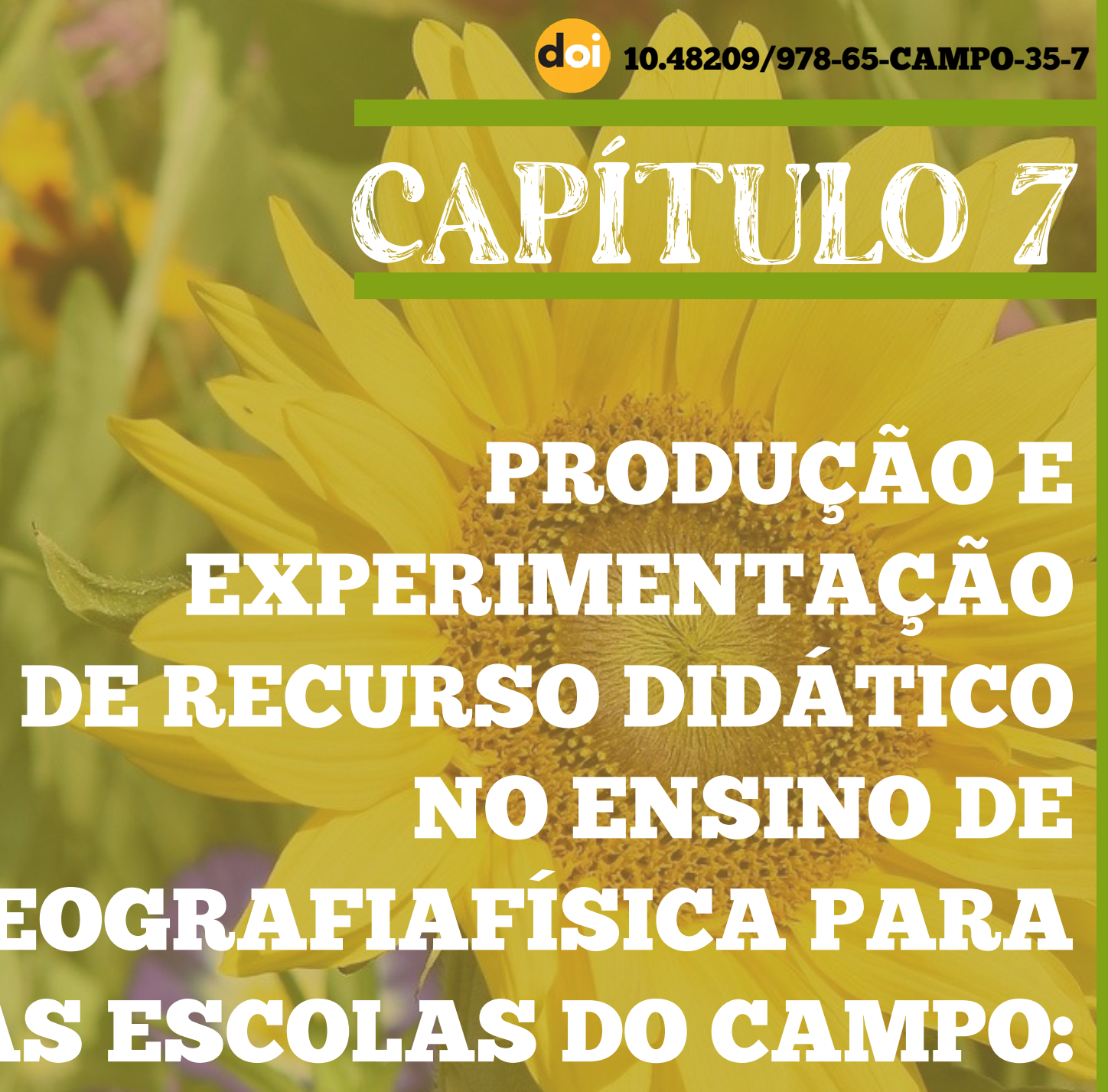
$A$ REPRESI WHCOÃO DA BACIA HIDROCRAFICA DO SEMMARIDO POR MEIO DE MAQUEHES Antonio Carlos Soares de Mota Rosicreide Soares Nogueira Tiago José Vasconcelos de Farias 
SABERES E EXPERIÊNCIAS DE PRATICAS PEDAGÓGICAS NO CONTEXTO EDUCACIONAL

\section{INTRODUÇÃ̃O}

Estudar a Geografia nos oportuniza conhecermos e compreendermos a relação entre o homem e a natureza, suas dinâmicas, suas interações e consequentes transformações, ou seja, o espaço geográfico. Todavia, para compreendermos de maneira mais ampla esses processos interativos e constitutivos do espaço geográfico, é importante que percebamos a importância dos elementos físicos do ambiente para o surgimento deste espaço. Assim sendo, o estudo da Geografia Física se caracteriza como fundamental para entendermos como os aspectos físicos da natureza são importantes para a constituição das atividades humanas, seja no contexto macro (continente, país, estado etc) ou micro da sociedade (comunidades rurais, pequenas cidades etc).

A ausência do exercício da contextualização ou mesmo o ensino de Geografia física ancorado em uma perspectiva tradicionalista, sendo esta decorativa, memorizadora, dificulta significativamente o processo de aprendizagem voltado para compreensão do espaço de vivência dos estudantes.

Duas questões importantes foram consideradas fundamentais para a realização desta pesquisa, desenvolvida no âmbito da participação em um projeto de extensão3: a realização de um levantamento bibliográfico sobre o ensino de Geografia Física nas escolas que constatou uma grande presença de uma perspectiva tradicional dentro deste componente curricular, e também a ausência de recursos didáticos que, trabalhando de maneira integrada aos conhecimentos, pudessem ser de grande valia para um processo de ensino-aprendizagem significativo. Além desses pontos apresentados, por fim, identificamos que a temática sobre bacias hidrográficas era abordada, no livro didático utilizado pelos estudantes do $6^{\circ}$ ano, de forma completamente descontextualizada, não dialogando com

3 Projeto de extensão "Produção de recursos didáticos no ensino de Geografia para as escolas do campo" foi desenvolvido durante o ano de 2019 na Escola Estadual de Ensino Fundamental e Médio Maria Balbina Pereira, situada do distrito de Santa Luzia do Cariri, zona rural do munícipio de Serra Branca/PB, no âmbito da Licenciatura Interdisciplinar em Educação do Campo, do Centro de Desenvolvimento Sustentável, da Universidade Federal de Campina Grande. 


\section{EDUCAÇÃO DO CAMPO:}

SABERES E EXPERIÊNCIAS DE PRATICAS PEDAGÓGICAS NO CONTEXTO EDUCACIONAL

a realidade de tais sujeitos e dificultando o processo de ensino-aprendizagem de uma temática tão importante no que tange a área da Geografia Física.

Outro fator determinante para utilizarmos o tema referente a bacias hidrográficas diz respeito à importância de realizarmos uma discussão, junto aos estudantes, sobre questões hídricas na nossa região (Semiárido brasileiro), abrangendo os mais variados aspectos (sociais, econômicos, culturais etc). Compreendendo, assim, que a presente temática se faz presente de maneira intensa na realidade desses estudantes, diferentemente da maneira como é exposta nos materiais didáticos por eles utilizados nas aulas de Geografia.

Nesse sentido, a presente pesquisa teve como objetivo produzir e experimentar maquetes que abordam a Geografia Física, especificamente a bacia hidrográfica do Semiárido e sua implicação no processo de ensino-aprendizagem em sala de aula através da mediação.

Importante compreendermos como a escola, enquanto um espaço de interação entre múltiplos saberes, necessita que os instrumentos pedagógicos, envolvidos no processo de ensino aprendizagem devam estar voltados a trabalhar em uma perspectiva de valorização da região Semiárida, pois, nesse sentido, Küster e Mattos (2007, p. 35) acredita que "a formação do ser humano é pensada e conduzida segundo algumas práticas e vivências fundamentais, que, combinadas e articuladas, matizam a convivência". Todavia, é preciso romper com a lógica preconceituosa que sempre esteve presentes nos materiais didáticos das escolas do Semiárido. Reis (2010, p. 112) vai tomar como exemplo os livros didáticos utilizados para evidenciar essa lógica:

Os livros didáticos que circulam na nossa região reforçam essa imagem negativa da região, do sujeito que vive no Semiárido, que é visto como "matuto" ou como um "sujeito sem saber". É essa a negatividade que se criou do Semiárido Brasileiro e que ainda está presente entre nós e que terminamos por assumi-la e proliferá-la. (REIS, 2010, p. 112).

Nesse sentido, o ensino de Geografia adquiri um papel fundamental, pois, para efetivarmos essa mudança de mentalidade amplamente deturpada da refe- 
SABERES E EXPERIÊNCIAS DE PRATTICAS PEDAGÓGICAS NO CONTEXTO EDUCACIONAL

rida região, precisamos compreender em todos os seus aspectos naturais, econômicos, sociais e culturais no âmbito do objeto de estudo da ciência geográfica: o espaço geográfico.

Todavia, o espaço geográfico que precisamos tomar como ponto de referência é o Semiárido, sendo esse, um espaço de vivência de milhões de sujeitos, isso em seus mais variados aspectos (econômicos, sociais, naturais, culturais etc). Dessa forma, o ensino de Geografia precisa ser significante, no sentido de trazer e fazer sentido para os sujeitos envolvidos nesse processo para a "construção de uma identidade regional" (Freitas et.al. 2009, p. 115). E como uma das ferramentas que podemos estar utilizando, dentro do ensino de Geografia, para efetivar essa nova perspectiva de educação, é a produção e utilização de recursos didáticos - em seus mais variados tipos - que tenham como objetivo central, buscar, através do processo de mediação, a articulação entre os conhecimentos geográficos e a realidade dos estudantes, no nosso caso, o Semiárido Brasileiro.

O conceito do que venha a ser recurso didático engloba uma infinidade de materiais que podem ser utilizados em sala de aula para trabalhar o conteúdo pelo docente. Nesse sentido, Souza (2007, p.111) vai definir recurso didático como sendo "todo material utilizado como auxílio no ensino - aprendizagem do conteúdo proposto para ser aplicado pelo professor a seus alunos". Dos simples pincéis, quadro-branco e livros didáticos, disponíveis em praticamente todas as escolas, até aparelhos tecnológicos, como computadores e projetores estão abarcados na ideia de recursos didáticos. A maquete, principal recurso didático abordado na realização desta pesquisa se caracteriza como um recurso extremamente interessante, do ponto de vista do ensino de Geografia física em sala de aula, pois:

[...] os materiais gráficos e cartográficos, entre outras linguagens, quando associados à construção de conceitos e conteúdos empregados no ensino-aprendizagem da Geografia ampliam as oportunidades de compreensão do espaço geográfico e da realidade em que os alunos se situam (SILVA; MUNIZ, 2012, p. 66).

Nesse sentido, a maquete como recurso didático, pode proporcionar, des- 
SABERES E EXPERIÊNCIAS DE PRATICAS PEDAGÓGICAS NO CONTEXTO EDUCACIONAL

de que utilizada de maneira correta, uma importante ferramenta de trabalho para as temáticas da Geografia Física como, por exemplo, geologia, geomorfologia e hidrografia, etc., correlacionando-as com a realidade na qual o alunado está inserido, ou seja, realizando o exercício da contextualização, e trazendo para a sala de aula uma maneira diferenciada de realizar a mediação do conhecimento.

Essa nova possibilidade de abordagem no processo de mediação em sala de aula que a maquete proporciona precisa ser melhor compreendida e exercitada pelos professores de Geografia, na medida em que:

Manipulando materiais concretos o aluno envolve-se fisicamente em uma situação de aprendizagem ativa. O caráter motivador é uma das funções do uso de tais recursos pois se sabe que o conhecimento na criança, parte do concreto para o abstrato [...] (SOUZA, 2007, p.113).

A maquete retrata o fenômeno espacial que deve está presente em cada centímetro da realidade dos sujeitos envolvidos no processo de mediação, especificamente com temas da Geografia Física. Sendo assim, o que necessita é que, o professor, possa utilizar a maquete para fazer que seus alunos vejam e construam esse significado de importância que o conhecimento possui. Para isso, a importância da maquete como representação da realidade no ensino de Geografia articulado com o Semiárido Brasileiro.

\section{DESENVOLVIMENTO}

A referida pesquisa foi realizada na Escola Estadual de Ensino Fundamental e Médio Maria Balbina Pereira, situada no distrito de Santa Luzia do Cariri, zona rural do município de Serra Branca/PB (figura 1). É um educandário estadual que atende aos estudantes do mencionado distrito, como também, das comunidades rurais: Angico, Boa Vista I, Boa Vista II, Cacimba Nova, Ingá, Maria Preta, Pé de Serra, Riacho do Buraco, Salão, Sussuaruna, Quixaba e o distrito de Sucuru. Sendo os sujeitos participantes, 18 (dezoito) estudantes de uma turma do $6^{\circ}$ ano do ensino fundamental do referido estabelecimento educacional Para o desenvolvimento desta pesquisa nessa escola do campo utilizamos os princípios da pesquisa qualitativa direcionada no âmbito da pesquisa-ação. 
Figura 1: Escola Estadual de Ensino Fundamental e Médio Maria Balbina Pereira.

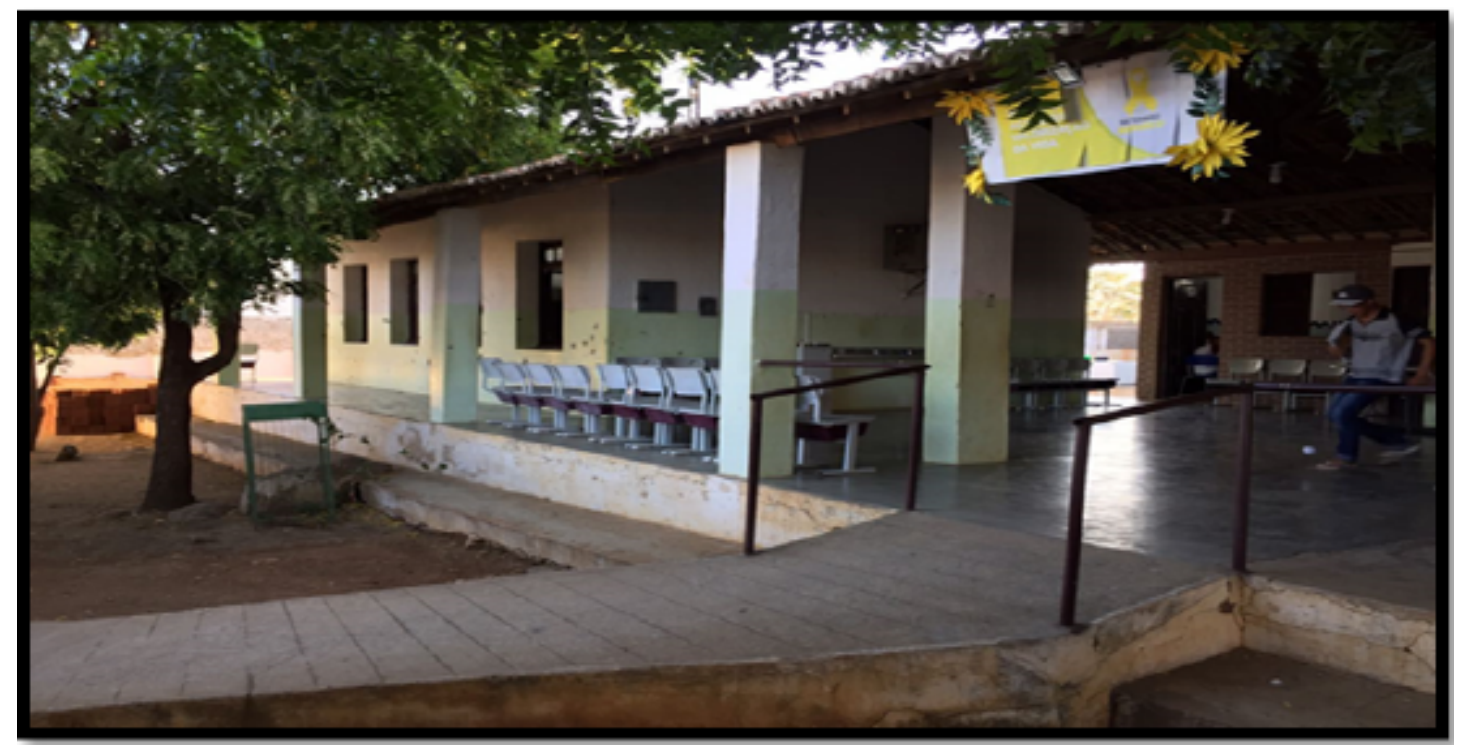

Fonte: Os autores

Sobre a escola, a mesma foi autorizada inicialmente a funcionar como Escola Rural em 30 de setembro de 1931, sendo regulamentada pelo decreto $\mathrm{n}^{\circ}$ 192 - 30/09/31. Nesse sentido, podemos compreender que a mesma se caracteriza como uma escola do campo, pois, mesmo a comunidade onde o referido educandário está localizado caracterizar-se por ser uma área urbana de distrito, a mesma possui uma forte ligação com o meio campesino, em vários aspectos (econômico, social etc), mas a definição no tocante a ser uma escola do campo discorre do fato da grande quantidade de jovens oriundos das zonas rurais circunvizinhas serem atendidos pela escola em questão.

Corroborando com tal afirmativa, Caldart et.al. (2012) apud Brasil (2010), vai definir a identidade das escolas do campo a partir de:

[...] sua vinculação às questões inerentes à sua realidade, ancorando-se na temporalidade e saberes próprios dos estudantes, na memória coletiva que sinaliza futuros, na rede de ciência e tecnologia disponível na sociedade e nos movimentos sociais em defesa de projetos que associem as soluções exigidas por essas questões à qualidade social da vida coletiva no País (CALDART et. al. 2012, p. 328 apud BRASIL, 2002).

Desta forma, fica evidente que para uma escola ser considerada do campo, e não apenas no campo, suas práticas educativas precisam estar voltadas para 
SABERES E EXPERIÊNCIAS DE PRATICAS PEDAGÓGICAS NO CONTEXTO EDUCACIONAL

a valorização do sujeito camponês em sua integralidade, fazendo-os sujeitos ativos, participantes na realização da ação educativa.

No que se refere aos procedimentos metodológicos, a utilização da pesquisa-ação para o direcionamento dos trabalhos desta pesquisa acontece por entendermos que seus pressupostos voltam-se para a transformação de uma realidade posta, com base nos resultados de um trabalho investigativo. É um processo de caráter emancipatório, cujo resultado é fruto da participação e interação dialógica entre os sujeitos pesquisados e o pesquisador (GHEDIN; FRANCO, 2011).

Nesse sentido, a realização desta pesquisa, ancorada no âmbito da pesquisa-ação, vai além de construir uma nova perspectiva de trabalho sobre a temática referente à bacia hidrográfica do Semiárido nas aulas de Geografia Física. Ela busca fazer com que os estudantes compreendam-se como sujeitos presentes, agentes ativos e modificadores de seu contexto. Contexto esse inserido em uma das bacias hidrográficas mais importantes do Semiárido Paraibano: a bacia hidrográfica do Rio Paraíba

Alicerçada nos princípios da pesquisa-ação, nossa pesquisa foi desenvolvida durante 7 (sete) momentos: planejamento, escolha do tema, aplicação de um questionário de verificação da aprendizagem, mediação pedagógica com o tema: "Bacia hidrográfica no Semiárido brasileiro", Construção das maquetes no âmbito acadêmico, experimentação das maquetes na sala de aula e reaplicação do questionário para verificação da aprendizagem.

Os dados coletados nesta pesquisa foram analisados de forma descritiva e interpretativa, uma vez que esta é caracterizada pela observação e correlação de fatos, buscando descrever as características ou relações existentes nas ações empreendidas em sala de aula, através da pesquisa-ação (GIL, 2016). 


\section{RESULTADOS E DISCUSSÃO}

A pesquisa-ação no contexto escolar: etapas da produção e experimentação das maquetes sobre bacia hidrográfica no Semiárido.

Fundamentada nos princípios da pesquisa-ação, nossa pesquisa foi desenvolvida em dois contextos, tanto em âmbito acadêmico, sendo este no Laboratório de Ensino de Geografia e Educação do Campo (LEGECAMPO ${ }^{4}$ ) como também e na Escola Estadual de Ensino Fundamental e Médio Maria Balbina Pereira, durante 7 (sete) momentos.

$1^{\circ}$ Momento - Planejamento em âmbito acadêmico: Neste primeiro momento, por intermédio de encontros com os membros participantes do LEGECAMPO, foi sendo realizado um levantamento bibliográfico sobre o uso de recursos didáticos para o ensino de geografia física, especificamente, a maquete como representação da bacia hidrográfica do Semiárido.

$2^{\circ}$ Momento - Escolha do tema do recurso didático: Durante a participação no nos momentos de planejamento identificamos que a temática sobre bacias hidrográficas era abordada, no livro didático utilizado pelos estudantes do $6^{\circ}$ ano, de forma completamente descontextualizada, não dialogando com a realidade de tais sujeitos e dificultando o processo de ensino-aprendizagem de uma temática tão importante no que tange a área da Geografia Física. Outro fator determinante para utilizarmos o tema referente a bacias hidrográficas diz respeito à importância de realizarmos uma discussão, junto aos estudantes, sobre questões hídricas no espaço geográfico em que eles estão inseridos: o Semiárido, abrangendo os mais variados aspectos (sociais, econômicos, culturais etc).

\section{$3^{\circ}$ Momento - Elaboração e aplicação do questionário de verificação} da aprendizagem: Essa etapa foi empreendida com o intuito de levantarmos informações acerca dos conhecimentos prévios dos estudantes no tocante a temática sobre bacias hidrográficas e acompanhar o processo de verificação da aprendizagem ao longo da experimentação do recurso didático na sala de aula.

$4 \quad$ Laboratório de Ensino de Geografia e Educação do Campo, vinculado ao curso de Licenciatura Interdisciplinar em Educação do Campo da Universidade Federal de Campina Grande. 
$4^{\circ}$ Momento - Mediação pedagógica: "Bacia hidrográfica no Semiárido brasileiro": A mediação pedagógica sobre a temática "Bacia hidrográfica no Semiárido brasileiro" foi preparada a partir dos resultados obtidos na aplicação do questionário realizada anteriormente. Trabalhamos o conceito de bacia hidrográfica, sua composição (nascente, rio principal, afluente etc) e buscando conhecer e compreender aspectos relacionados à caracterização da bacia hidrográfica do rio Paraíba (principal rio da região onde a escola está localizada), como também discutimos questões relacionadas à degradação ambiental dessa bacia. Foram utilizados como recursos metodológicos: o quadro-branco, pincel, datashow, notebook, vídeo e imagens que elucidassem a temática trabalhada e dialogasse com a proposta de uma aula dinâmica e contextualizada.

$5^{\circ}$ Momento: Construção das maquetes no âmbito acadêmico: A partir de momentos de planejamento e pesquisa para conhecer as melhores técnicas de construção, iniciamos a produção de duas maquetes (Fig. 2 e 3) sobre bacias hidrográficas em diferentes regiões geográficas e, no processo de construção, acrescentando os principais elementos presentes, tanto em áreas de rios permanentes como também intermitentes (Fig. 4, 5, 6 e 7).

Figuras 2 e 3: Etapas de construção das maquetes
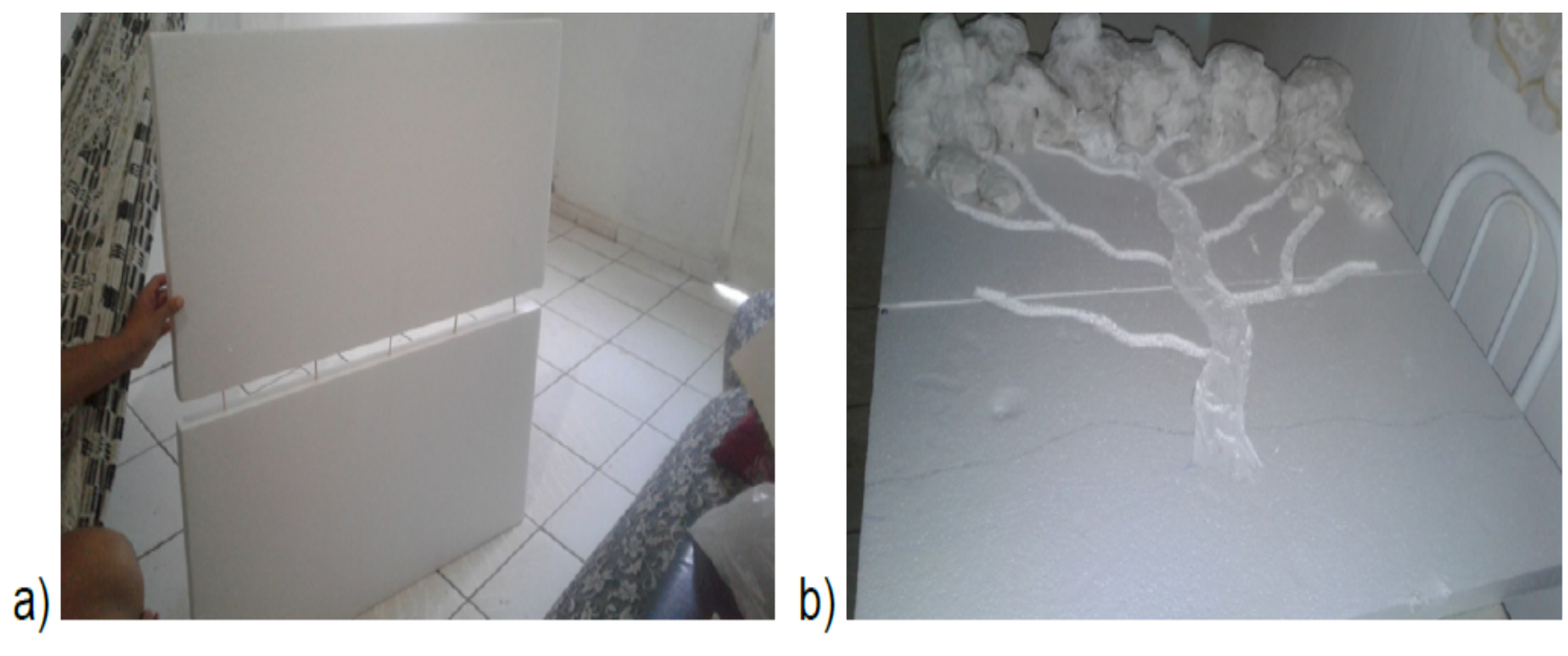

Fonte: Os autores 
Figuras 4, 5, 6 e 7: Maquetes em processo de finalização

c)

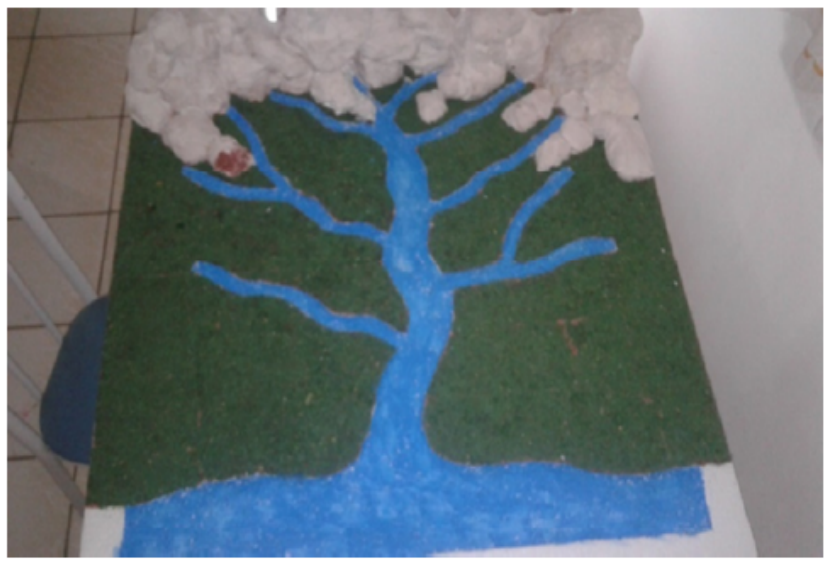

e)

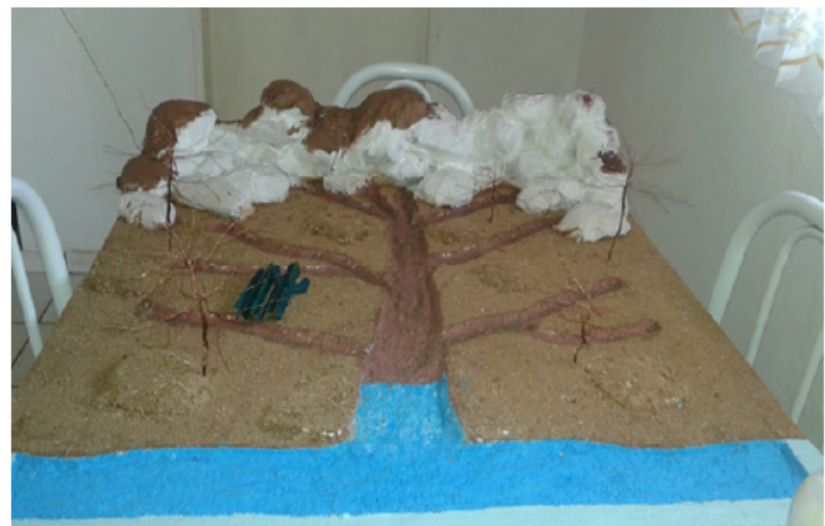

Fonte: Os autores
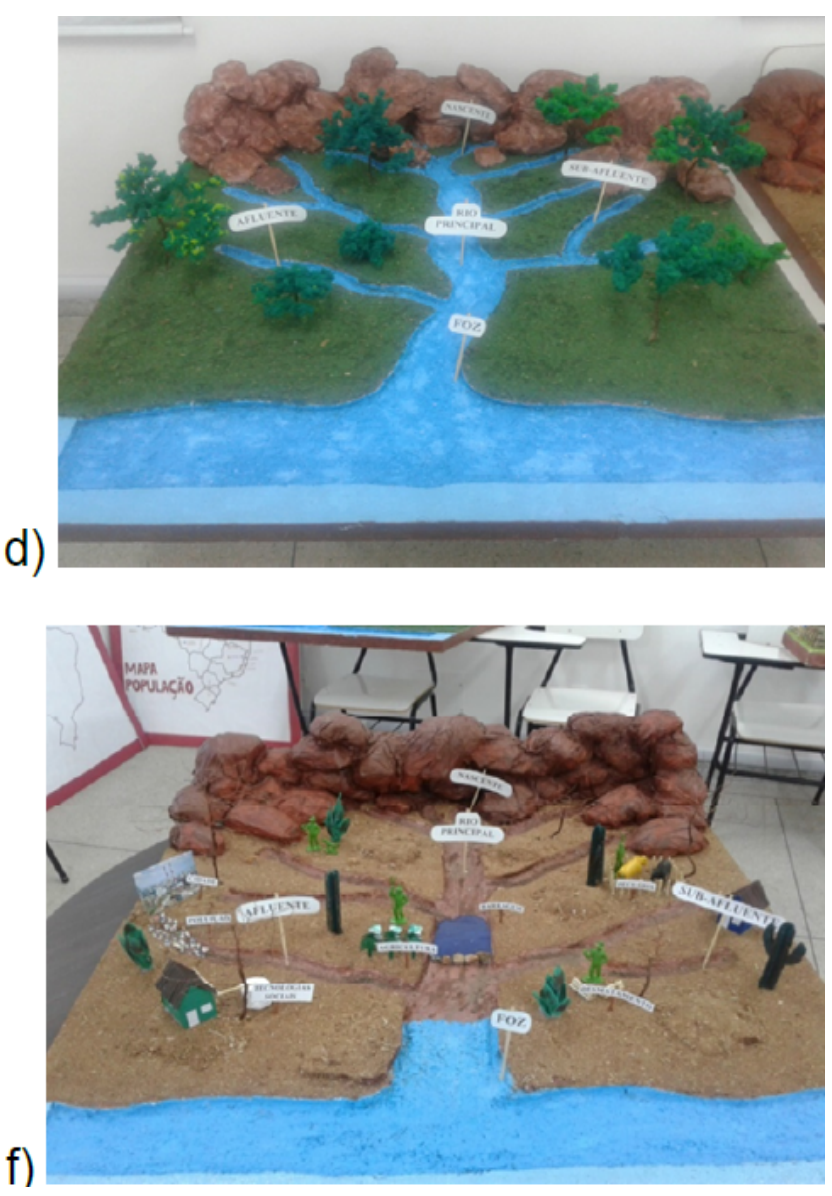

$6^{\circ}$ Momento - Experimentação das maquetes na sala de aula: A dinâmica de experimentação se deu na forma de uma estratégia didática, que, guiado pelo conjunto de sequências esquematizadas no quadro a seguir, mostrou-se como uma atividade didaticamente participativa pelos estudantes.

Quadro 1: Sequência didática para a experimentação das maquetes

\begin{tabular}{|c|c|}
\hline$N^{\circ}$ & Etapas da Sequência \\
\hline 1 & $\begin{array}{r}\text { A experimentação começará dividindo-se a turma em dois grupos, } \\
\text { aleatoriamente. }\end{array}$ \\
\hline 2 & Ambos os grupos decidem, na sorte, qual começará respondendo. \\
\hline 3 & $\begin{array}{r}\text { Haverá uma caixa verde onde estará as perguntas sobre o tema e uma } \\
\text { caixa vermelha onde estará as respostas. }\end{array}$ \\
\hline
\end{tabular}


SABERES E EXPERIÊNCIAS DE PRÁTICAS PEDAGÓGICAS NO CONTEXTO EDUCACIONAL

\begin{tabular}{|c|c|}
\hline 4 & $\begin{array}{c}\text { O grupo sorteará uma pergunta da caixa verde para responder } \\
\text { e procurará, dentro de } 1 \text { (um minuto), a respostas nas placas } \\
\text { presentes na caixa vermelha. }\end{array}$ \\
\hline 5 & $\begin{array}{l}\text { O grupo que for responsável por responder a pergunta não poderá } \\
\text { repassá-la ao grupo adversário sob hipótese nenhuma. }\end{array}$ \\
\hline 6 & Os grupos responderão as perguntas de forma alternada. \\
\hline 7 & $\begin{array}{c}\text { A resposta da pergunta deverá ser respondida e colocada sua placa } \\
\text { correspondente na maquete. }\end{array}$ \\
\hline 8 & $\begin{array}{l}\text { Cada integrante de ambos os grupos só poderá colocar as placas } \\
\text { nas maquetes uma vez. }\end{array}$ \\
\hline 9 & $\begin{array}{l}\text { A dinâmica finaliza quando um dos grupos mais acertar perguntas e } \\
\text { colocar as placas nas maquetes nos lugares corretos. }\end{array}$ \\
\hline
\end{tabular}

Fonte: Os autores

Figura 8: Caixas contendo as perguntas e as respostas para a sequência didática

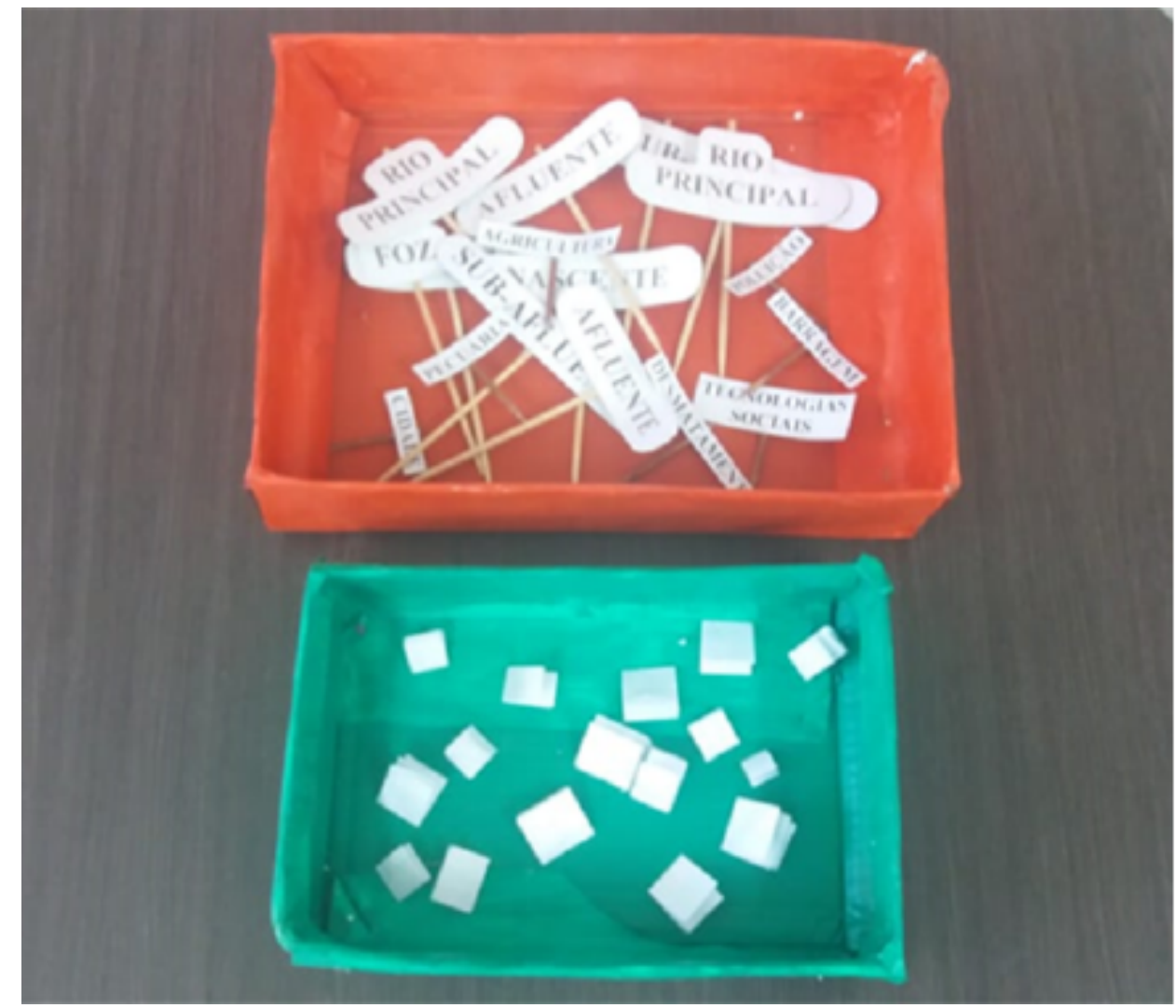

Fonte: Os autores 
SABERES E EXPERIÊNCIAS DE PRATICAS PEDAGÓGICAS NO CONTEXTO EDUCACIONAL

Durante a realização da atividade, podemos observar o quanto os estudantes envolvidos nessa dinâmica mostraram domínio das questões levantadas no que diz respeito à temática sobre bacias hidrográficas, principalmente no tocante a aquela situada no Semiárido brasileiro (Fig. 9 e 10). Além de demonstrarem os conhecimentos sobre os aspectos físicos do conteúdo, os estudantes manifestaram seu saber sobre as questões relacionadas às ações humanas presente nas bacias do Semiárido brasileiro.

Nas duas maquetes utilizadas, os estudantes identificaram acertadamente os elementos físicos que compõe as bacias (nascente, rio principal, afluente, subafluente e foz), entretanto no recurso didático referente ao Semiárido, além de sinalizarem os aspectos naturais da bacia, os estudantes também evidenciaram bem os aspectos das ações humanas empreendidas nesse tipo espaço geográfico que se caracteriza as bacias hidrográficas no Semiárido, como a agricultura, a pecuária, a poluição causada pelos centros urbanos, dentre outras ações.

Figuras 9 e 10: Realização da sequência didática em sala de aula.

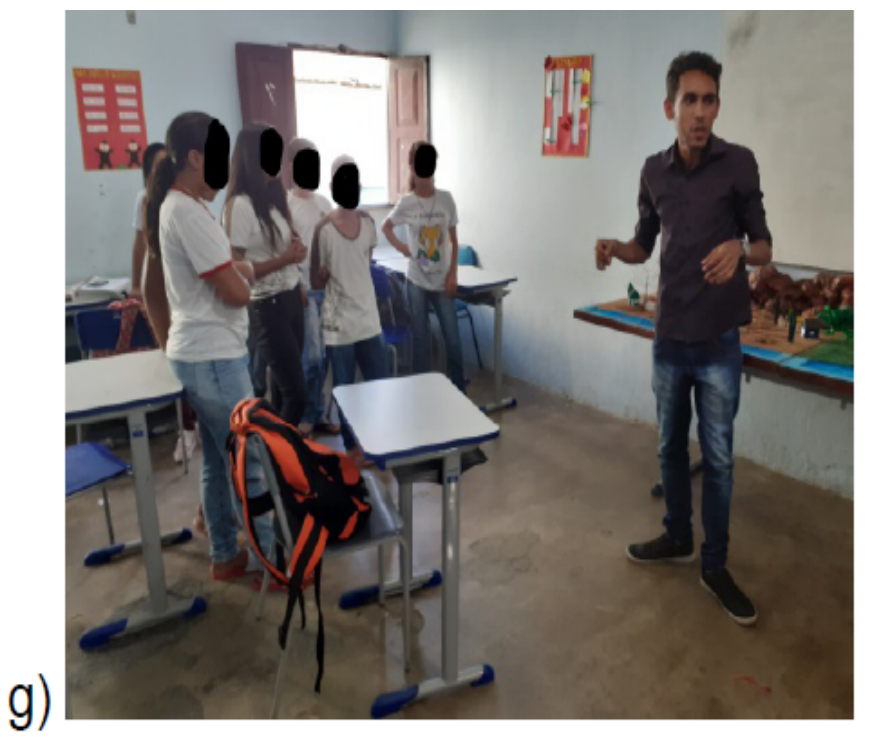

h)

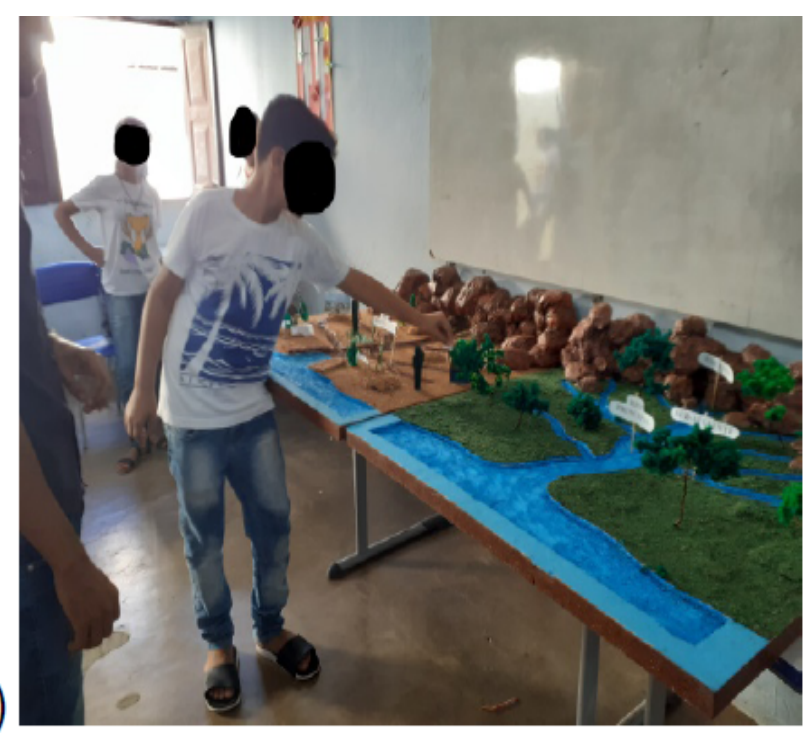

Fonte: Os autores

$7^{\circ}$ Momento - Reaplicação do questionário de verificação da aprendizagem: Neste momento, com o intuito de verificar a aprendizagem sobre os conhecimentos construídos no tocante a bacias hidrográficas, principalmente no 
SABERES E EXPERIÊNCIAS DE PRÁTICAS PEDAGÓGICAS NO CONTEXTO EDUCACIONAL

Semiárido brasileiro, foi realizada a segunda aplicação do questionário. A reaplicação do questionário foi um momento de certeza da constatação realizada nos momentos anteriores da pesquisa. A turma, de maneira geral, desenvolveu um aprendizado significativo sobre a temática trabalhada, atendendo as expectativas do inicio do trabalho desta pesquisa.

\section{ACOMPANHAMENTO DO PROCESSO DE ENSINO-APRENDI- ZAGEM}

Efetivar o processo de mediação em sala de aula é uma tarefa que exige o estabelecimento de uma relação de comprometimento entre os sujeitos envolvidos nesta ação, tanto da parte do professor, sendo ele o responsável por exercer a função de mediar o conhecimento, como também por parte dos estudantes envolvidos, sendo estes, os mediados. A experiência da aprendizagem mediadora se caracteriza como sendo um processo interativo em que o mediador (professor) se coloca como um agente que facilita a aprendizagem dos mediados (estudantes) por meio da utilização, em sala de aula, das mais diferentes estratégias pedagógicas (MÖLLER, 2015).

Neste sentido, a metodologia de produção e utilização das maquetes sobre as bacias hidrográficas, sobretudo aquela que diz respeito ao Semiárido brasileiro, se caracteriza como uma experiência de aprendizagem mediadora, pois a mesma se propõe a trabalhar, por meio do uso dos recursos didáticos acima citados, o conhecimento construído sob a temática desta pesquisa, potencializando o processo de ensino aprendizagem.

Para o acompanhamento do processo de aprendizagem dos sujeitos desta pesquisa, durante a mediação no âmbito da pesquisa-ação, foi utilizado como instrumento de coleta de dados "questionário", com sua aplicação antes e depois da ação mediadora com o intuito de observar os conhecimentos prévios e posteriores sobre a compreensão dos educandos sobre a temática abordada nesta pesquisa. 
SABERES E EXPERIÊNCIAS DE PRÁTICAS PEDAGÓGICAS NO CONTEXTO EDUCACIONAL

A seguir, para a constatação desta potencialização do processo de aprendizagem, iremos apresentar os quadros que evidenciam as respostas coletadas durante o primeiro momento de aplicação do questionário, quando grande parte da turma não possuía o domínio básico do conteúdo sobre bacias hidrográficas, e o segundo momento de resposta do questionário, realizado após o processo de mediação.

Quadro 2: Percepção dos estudantes sobre o conceito de bacia hidrográfica

\begin{tabular}{|c|c|c|}
\hline ESTUDANTE & $\begin{array}{c}\text { ANTES DA MEDIAÇÃO } \\
\text { PEDAGÓGICA }\end{array}$ & $\begin{array}{l}\text { DEPOIS DA MEDIAÇÃO } \\
\text { PEDAGÓGICA }\end{array}$ \\
\hline A & Eu não sei & $\begin{array}{c}\text { a bacia hidrografica pra mim é } \\
\text { quando tem um rio principal } \\
\text { que ajunta água de rios mais } \\
\text { pequenos }\end{array}$ \\
\hline B & Não sei & $\begin{array}{l}\text { e uma região que tem rio } \\
\text { principal e afluente }\end{array}$ \\
\hline C & Não sei & $\begin{array}{l}\text { Conjunto de terras, que contém o } \\
\text { seu rio principal e seus afluentes }\end{array}$ \\
\hline D & Não & Não compareceu \\
\hline $\mathbf{E}$ & Não sei & Não compareceu \\
\hline $\mathbf{F}$ & Não sei & $\begin{array}{l}\text { a bacia hidrográfica é uma região } \\
\text { que tem rio principal os afluentes }\end{array}$ \\
\hline $\mathbf{G}$ & Não sei & $\begin{array}{c}\text { Uma area de terra que tem rio } \\
\text { principal e afluentes e } \\
\text { subafluente }\end{array}$ \\
\hline
\end{tabular}




\begin{tabular}{|c|c|c|}
\hline H & Não sei & Não compareceu \\
\hline I & Não sei & $\begin{array}{c}\text { São conjuntos de terras que } \\
\text { tem rio principal, afluente, } \\
\text { nacente e foz }\end{array}$ \\
\hline $\mathbf{J}$ & Não sei & $\begin{array}{l}\text { É a area que tem afluente, } \\
\text { sub-afluente e rio principal }\end{array}$ \\
\hline $\mathbf{K}$ & Não sei & $\begin{array}{l}\text { Pra mim é uma região que tem } \\
\text { rio principal, afluente }\end{array}$ \\
\hline $\mathbf{L}$ & Não sei & é tipo vários rios de uma região \\
\hline M & Eu não sei & Tem rio principal, afluente, \\
\hline $\mathbf{N}$ & Não sei & $\begin{array}{c}\text { É formada por uma area de terra } \\
\text { que tem afluente, rio principal, } \\
\text { foz. }\end{array}$ \\
\hline $\mathbf{0}$ & Não sei & $\begin{array}{l}\text { bacia hidrográfica é uma região } \\
\text { que tem um rio principal e } \\
\text { afluentes e sub-afluentes }\end{array}$ \\
\hline $\mathbf{P}$ & Não sei & Não compareceu \\
\hline $\mathbf{Q}$ & Não sei & $\begin{array}{c}\text { Pra mim bacia hidrográfica é } \\
\text { lugar que tem vários rios, rio } \\
\text { principal, }\end{array}$ \\
\hline $\mathbf{R}$ & Não sei & Não compareceu \\
\hline
\end{tabular}

Fonte: Os autores 


\section{CONCLUSÃO}

A prática pedagógica dentro do ensino de Geografia para as escolas do campo necessita estar ancorada na perspectiva da educação contextualizada. Uma educação que leve para a sala de aula, as discussões de aspectos que se fazem presentes nos contextos dos estudantes do Semiárido brasileiro, paraibano e caririzeiro e que a partir daí sejam problematizadas e se tornem os eixos fundantes na construção do conhecimento coletivo que a escola deve proporcionar, como foi realizada nesta pesquisa.

Desta forma, a realização desta pesquisa foi de grande importância para compreendermos como a construção e o emprego das maquetes, sobretudo aquela que diz respeito ao Semiárido foi capaz de potencializar o processo de ensino aprendizagem dos estudantes na disciplina de Geografia, através da ação de mediação do conhecimento. A realização da mediação pedagógica, para além de promover uma maior interação entre os estudantes nos momentos de discussão que o conteúdo suscitava, ela foi primordial para instigar nos estudantes a curiosidade e o interesse pela temática abordada através do emprego das maquetes para materializar o assunto sobre bacias hidrográficas, este tratado nos livros didáticos de forma abstrata e distante da realidade dos sujeitos do Semiárido brasileiro.

Assim, verificamos que nossa pesquisa, fundamentada nos pressupostos da pesquisa-ação, e esta, conduzida na perspectiva da educação mediadora contextualizada, contribuiu significativamente para que os estudantes, sujeitos deste pesquisa, compreendessem a importância do estudo das bacias hidrográficas, sobretudo no Semiárido, e suas implicações no contexto desses estudantes. Processo todo esse, mediado e potencializado pelo uso das maquetes em sala de aula. 


\section{REFERENCIAS}

CALDART, Roseli Salete (org). Dicionário Educação do Campo. Rio de Janeiro: Expressão Popular, 2012.

FREITAS, Naceli Barbosa. et al. A relação campo-cidade: o ensino de Geografia e as especificidades do Semiárido. In: Caderno multidisciplinar - Educação e contexto do Semiárido Brasileiro: múltiplos espaços para o exercício da contextualização. Juazeiro: Selo editorial RESAB, 2009. p. 105-117.

GHEDIN, Evandro. FRANCO, Maria Amélia Santoro. Questões de método na construção da pesquisa em educação. $2^{a}$ ed. São Paulo: Cortez, 2011.

GIL, Antonio Carlos. Métodos e técnicas de pesquisa social. $6^{a}$ ed. São Paulo: Atlas, 2016.

KÜSTER, Angela. MATTOS, Beatriz Helena Oliveira de Mello. Educação no contexto do semi-árido brasileiro. Juazeiro: Fundação Konrad Adenauer: Selo editorial RESAB, 2007.

MÖLLER, Cristina Almeida. Mediar a aprendizagem. In: XII Congresso Nacional de Educação. Anais. 2015. Disponível em: https://educere.bruc.com.br/arquivo/ pdf2015/17452_11092.pdf. Acesso em: 29 out. 2019.

REIS, Edmerson dos Santos. Educação para a convivência com o Semiárido: desafios e possibilidades. In: SILVA, Conceição de Maria de Souza e.; CANTALICE, Maria Luzia de.; ALENCAR, Maria Tereza de.; SILVA, Waldirene Alves Lopes da.. (Orgs.). Semiárido Piauiense: Educação e Contexto. Campina Grande: INSA. 2010. p. 109-129.

SILVA, Vládia. MUNIZ, Alexsandra Maria Vieira. A geografia escolar e os recursos didáticos: o uso das maquetes no ensino-aprendizagem da geografia. Geosaberes, Fortaleza. v. 3, n. 5, p. 62-68, 2012. Disponível em: http://www.geosaberes.ufc.br/geosaberes/article/view/117 . Acesso em: 04 fev. 2019.

SOUZA, Salete Eduardo de. 0 uso de recursos didáticos no ensino escolar. In: I Encontro de Pesquisa em Educação, IV Jornada de Prática de Ensino, XIII Semana de Pedagogia da UEM: "Infância e Práticas Educativas". Arq Mudi. 2007. Disponível em: https://www.pec.uem.br/pec_uem/revistas/arqmudi/volume_11/ suplemento_02/artigos/019.pdf .Acesso em: 16 abr. 2019. 

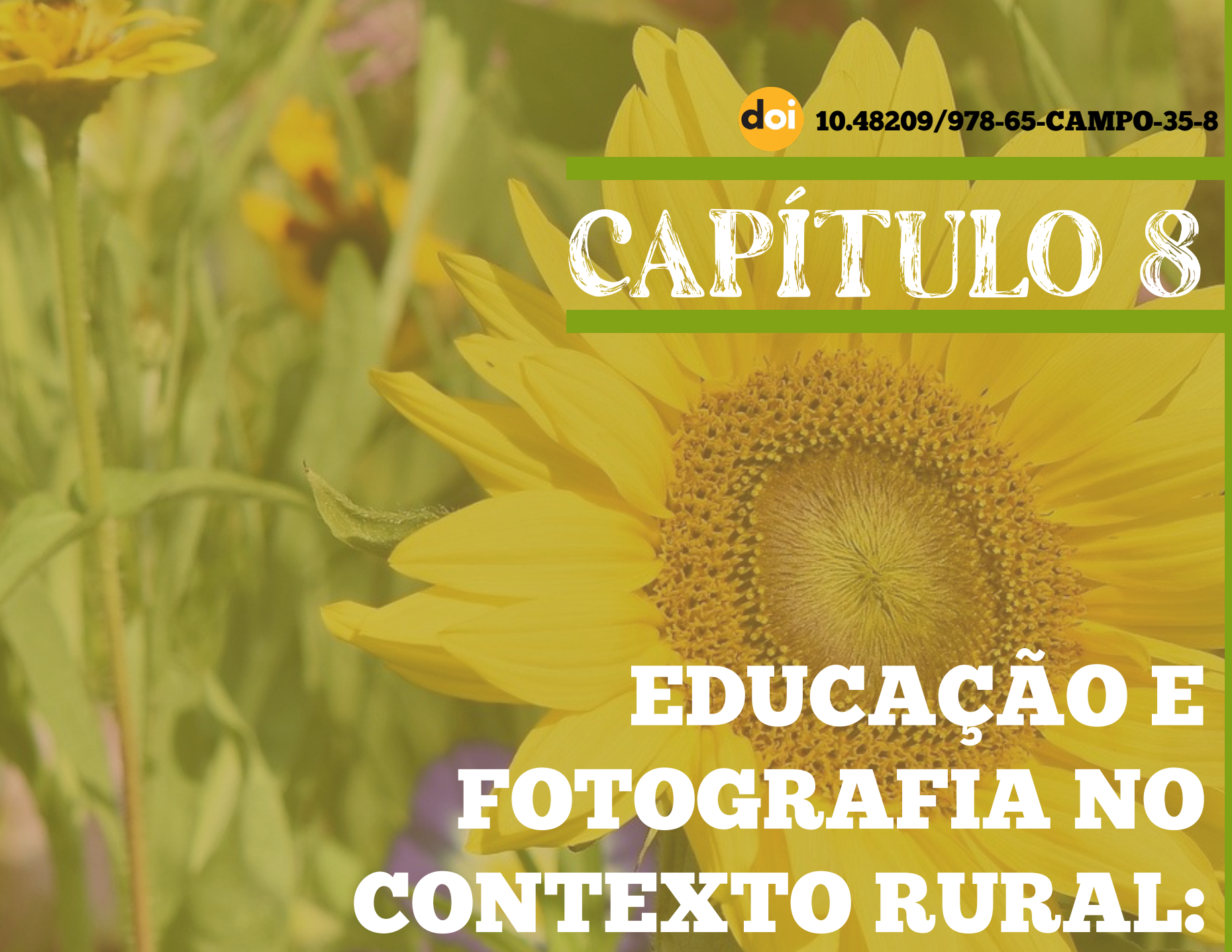

\section{chMintos PPAIStCHS}

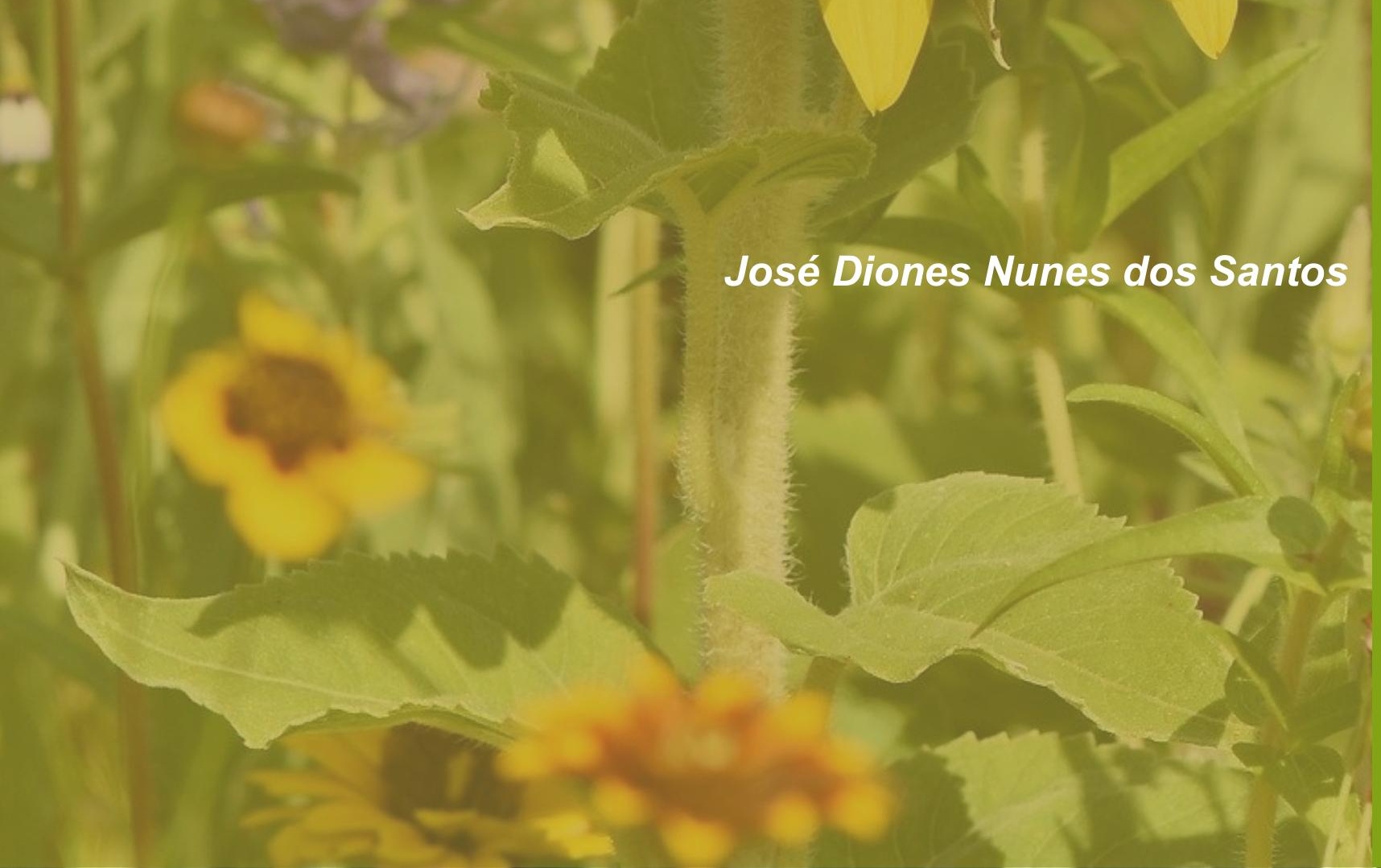


SABERES E EXPERIÊNCIAS DE PRÁTICAS PEDAGÓGICAS NO CONTEXTO EDUCACIONAL

\section{Resumo}

Este artigo aborda o uso de fotografias em práticas pedagógicas, desenvolvidas no ano de 2017, com estudantes do Ensino Fundamental I da Escola Municipal Antônio Alves Feitosa, localizada na Zona Rural do município de Camalaú/PB. Busca-se relatar tal experiência, verificando-se quais são as práticas de ensino que estão sendo desenvolvidas no currículo da escola pelos professores. Os discentes envolvidos nessas ações são transportados diariamente de ônibus escolar e kombi de suas residências até a escola. Durante esse percurso, os caminhos e as paisagens passam muitas vezes despercebidos, devido, obviamente, a serem tão comuns aos olhares discentes cotidianos. Vinte e três estudantes, dez, do segundo ano e, treze, do terceiro ano do Ensino Fundamental I, utilizaram-se de uma máquina fotográfica/filmadora handycam HD Sony para registrar os caminhos e as paisagens, estimulando neles a percepção, a sensibilidade e a produção de um "novo olhar" acerca do que descobriram ao fotografarem. O objetivo era demonstrar pelas fotografias os detalhes dos caminhos e das paisagens que esses discentes não conseguiam perceber a olho nu, por serem tão rotineiras e presentes em suas vidas. O arquivo fotográfico produzido foi composto por 50 fotografias, destas, foram escolhidas pelos estudantes 33 fotos. Se, por um lado, os registros fotográficos realizados pelos professores mostram momentos de descontração vivenciados pelos discentes, durante os simples atos de caminhar, subir em árvores, etc., por outro lado, alguns dos registros feitos pelos estudantes revelam a difícil realidade vivenciada cotidianamente por eles durante o percurso casa/escola/casa. Neste sentido, percebemos que o trabalho com a fotografia na escola possibilita, tanto para professores quanto para estudantes, o despertar de um olhar mais sensível, aguçado e crítico, diante da realidade registrada e, que, antes, apresentava-se de modo banal, sem muita importância; e transforma o processo ensino-aprendizagem também em algo prazeroso, vívido e reflexivo. As fotos produzidas ficaram expostas em um mural montado no pátio da escola, durante todo o ano letivo de 2017.

Palavras-chave: Fotografia; Currículo; Prática de Ensino; Ensino Fundamental I.

\section{INTRODUÇÃ̃O}

Durante os anos de 2008 a 2016, as escolas rurais do município de Camalaú, no Estado da Paraíba, foram nucleadas. O processo de nucleação, no Brasil, segundo Gonçalves (2010, p.1), foi particularmente forte na década de 
SABERES E EXPERIÊNCIAS DE PRÁTICAS PEDAGÓGICAS NO CONTEXTO EDUCACIONAL

1990, quando as reformas educacionais na educação básica, induzidas pela LDB 9.394/96, priorizaram o Ensino Fundamental com a criação do FUNDEF e o FNDE. Ao estabelecerem critérios para a transferência de recursos financeiros às escolas públicas do Ensino Fundamental, estimularam a municipalização do mesmo, processo que terminou por resultar no fechamento de várias escolas multisseriadas. Os estudantes das unidades desativadas foram então "nucleados" em centros urbanos e escolas maiores.

No caso de Camalaú-PB, as escolas rurais foram fechadas, seguindo orientações da Secretaria de Educação da época. No entanto, os alunos foram remanejados para escolas estratégicas na própria Zona Rural, onde o número de alunos era maior em relação às demais. Ou seja, ficaram ativas no município somente cinco escolas rurais para atender os discentes das outras 12 que foram extintas. Após a nucleação, uma dessas escolas rurais "sede" ficou sendo a Escola Municipal Antônio Alves Feitosa (EMAAF), locus da pesquisa aqui relatada. Sua nucleação ocorreu no ano de 2013.

No ano de 2017, foram atendidos aproximadamente 80 estudantes. Atualmente, a escola atende um número menor, cerca de 60 crianças. A escola possui cinco salas de aulas para atender seis turmas, da Educação Infantil ao $5^{\circ}$ Ano do Ensino Fundamental I, em consequência disso, duas dessas turmas, todos os anos, tornam-se uma única turma multisseriada.

Durante os duzentos dias letivos, os alunos são transportados diariamente de ônibus escolar e kombi de suas residências até a escola. Esses alunos são oriundos de diversas outras comunidades rurais (Sítio Salgadinho, Sítio Tortão, Sítio Porteiras, Sítio Projeto, Sítio Baraúnas, Sítio Volta, Sítios Impoeiras 1 e 2). Observando-se essa dinâmica, algumas questões foram, então, trazidas à tona: será que esses alunos perceberiam as belezas naturais existentes durante 0 percurso casa/ escola/ casa? O que se haveria durante os diversos caminhos e com que tipos de paisagens eles se deparariam no trajeto? Existiria no currículo da escola alguma temática direcionada para essas questões? 


\section{PROCEDIMENTOS METODOLÓGICOS}

Durante essa pesquisa, deparei-me com crianças de realidades bem distintas da minha, inclusive, muitas delas, socialmente vulneráveis, frequentando a escola pelo fato de lá encontrarem alimentação, o quê, muitas vezes era inexistente em suas casas. A grande maioria dos pais dessas crianças passa o dia inteiro trabalhando fora, tanto em pequenas confecções de roupas, como no plantio de tomate, cenoura, beterraba e cebola, buscando adquirir o salário no fim do mês para o sustento da família. Assim, muitas dessas crianças acabam por ficar, boa parte de tempo, sozinhas em suas residências.

Buscar informações que corroborem com uma análise mais profunda da realidade vivenciada por esses alunos na escola, estimula também a questionar sobre que tipo de currículo está sendo ofertado pela escola. As instituições de ensino podem cumprir um papel importante em relação à promoção da igualdade social. Young (2007, p.1297) nos aponta que as escolas precisam considerar seriamente a base de conhecimento do currículo, mesmo quando isso parecer ir contra as demandas dos alunos (e às vezes de seus pais). Os docentes devem perguntar: será o currículo um meio para que os alunos possam adquirir conhecimento poderoso? Para crianças de lares desprovidos, a participação ativa na escola pode ser a única oportunidade de adquirir conhecimento poderoso e serem capazes de caminhar, ao menos intelectualmente, para além de suas circunstâncias locais e particulares.

Foi preciso, destarte, entrevistar todos os docentes em atuação no tocante ao currículo ofertado pela escola. Obtivemos, assim, a informação de que, em determinados momentos do ano letivo, segundo o currículo da EMAAF, os docentes trabalham questões pertinentes à comunidade em suas turmas. Cada educador é responsável por uma temática específica que irá ser desenvolvida em sala de aula pelas turmas. As temáticas são as seguintes, de acordo com o nível e/ou a série em que os discentes estejam: os profissionais (Educação Infantil); os 
professores ( $\left.1^{\circ} \mathrm{Ano}\right)$; tipos de paisagem: urbana e rural $\left(2^{\circ}\right.$ e $\left.3^{\circ} \mathrm{Anos}\right)$; os poetas $\left(4^{\circ}\right.$ e $5^{\circ}$ Anos).

As turmas de $2^{\circ}$ e $3^{\circ}$ Anos estavam trabalhando justamente com a referida temática, "tipos de paisagem", que estava presente tanto no currículo da escola quanto nos livros didáticos, e, propor uma atividade com fotografia aos alunos nesses anos escolares, nos parecia vir bem a calhar. Assim, propusemos aos alunos das turmas de $2^{\circ}$ e $3^{\circ}$ Anos da Educação Fundamental I que, junto com os seus professores, caminhassem a pé parte do percurso feito diariamente de ônibus e kombi para a escola, acreditando que os docentes precisam vivenciar constantemente com seus alunos práticas de ensino, tanto dentro como fora do espaço escolar formal.

Foi solicitado aos discentes que fotografassem durante o percurso, os caminhos e as paisagens que eles acreditavam ser interessantes para as pessoas conhecerem, para além daqueles registrados nas figuras contidas nos manuais didáticos. O objetivo dessa atividade era demonstrar pelas fotografias os detaIhes dos caminhos e paisagens que os próprios estudantes não conseguiam perceber a olho nu, por serem tão rotineiras e presentes em suas vidas. Também neste estudo resolvi aplicar a metodologia da História Oral, por contribuir, segundo Neves (2000, p.109) para a construção e reconstrução da identidade histórica dos sujeitos.

Os professores, por sua vez, ficaram incumbidos de registrarem pela fotografia, utilizando-se do aparelho celular, as vivências dos alunos durante o trajeto. Já os vinte e três alunos participantes, dez do segundo ano, e treze do terceiro ano, manusearam uma máquina fotográfica/filmadora handycam HD Sony para registrar os caminhos e as paisagens, estimulando a percepção, a sensibilidade e a produção de um "novo olhar" acerca do que descobriram ao fotografarem (conferir os anexos). Freire (1996, p.53) afirma ser preciso permanecermos amorosamente cumprindo o nosso dever e não deixarmos de lutar politicamente por nossos direitos e pelo respeito à dignidade de nossa tarefa, assim, como pelo zelo devido ao espaço pedagógico em que atuamos com nossos alunos. 


\section{FUNDAMENTAÇÃO TEÓRICA, APRESENTAÇÃO E DISCUSSÃO DOS RESULTADOS}

Segundo Freire (1996, p.21), ensinar não é transferir conhecimento, mas criar possibilidades para a sua própria produção ou a sua construção. Quando se entra numa sala de aula deve-se estar aberto a indagações, à curiosidade, às perguntas dos alunos, a suas inibições; como um ser crítico e inquiridor, inquieto em face da tarefa que tem - a de ensinar e não a de transferir conhecimento.

No processo de manuseio da câmera fotográfica, pouquíssimos alunos sentiram dificuldades com o equipamento. Após a captação das imagens, os alunos retornaram para a escola e na sala de aula do $2^{\circ} \mathrm{Ano}$, foi montado o aparelho de datashow, projetando no quadro branco o registro fotográfico realizado por eles.

De acordo com as considerações feitas por Zóboli (2014, p.203), é possível adequar os recursos tecnológicos ao planejamento de sala de aula de maneira que a mesma se transforme em lugar atrativo, instigante, prazeroso e interessante para o estudante.

O arquivo iconográfico geral foi composto por 50 fotografias (nos anexos, ao final desse artigo, pode ser conferida boa parte delas), destas, os estudantes selecionaram 33, sendo: (1) insetos; (1) agricultores trabalhando na roça; (1) casa de alvenaria; (1) luz e sombras de galhos de árvore nas pedras, (1) túmulo de um homem que morreu de acidente de moto próximo à escola; (3) bar da azeitona, o ponto turístico da comunidade; (3) objetos como tapetes e sandálias desgastadas pelo tempo, rodas de ferro de carro de boi, pegadores de brasas e grelhas de assar carnes; (4) diversidades de flores; (6) diferentes ângulos do Rio Paraíba, agora banhado pelas águas da Transposição do Rio São Francisco; (12) plantação de coqueiros, milhos, mangueiras, cajueiros, pinheiros, mandacaru, cabreiras, etc.. Importante ressaltar que foi solicitado também aos estudantes que justificassem a escolha de cada fotografia.

No registro fotográfico dos estudantes, percebe-se a total imersão e a verdadeira entrega deles para atingirem o que Ihes havia sido proposto. Registrar 
SABERES E EXPERIÊNCIAS DE PRATICAS PEDAGÓGICAS NO CONTEXTO EDUCACIONAL

pela fotografia a memória do lugar, os caminhos e as paisagens é algo realmente vívido, prazeroso, inovador, resultante de aprendizado mútuo, entre alunos e professores. Devemos ser sujeitos de nossa história (Freire,1996, p.23). Percebe-se na fala dos alunos uma admiração quanto ao registro fotográfico, como em: "[...] mas, tio, nem acredito que eu tirei essa foto! Foi eu mesmo? Essa máquina de retrato é boa, viu." (Flávio, 8 anos) e "[...] vou tirar a foto dos meninos lá em cima do cruzeiro do bar da azeitona. Tio, deixa? Eu quero tirar também uma do pé de manga. Deixa eu tirar duas fotos?" (Joaquim, 8 anos).

Não há docência sem discência, para Freire (1996, p.12), as duas são necessariamente importantes para explicar seus agentes, mesmo apresentando diferenças. Destarte, quem ensina aprende ao ensinar e quem aprende ensina ao aprender. Quem ensina, ensina alguma coisa para alguém. Espera-se, certamente, atitudes assim dos professores no exercício da docência, responsabilidade ética, constituída de aprendizado socialmente adquirido no processo de mediação.

Os registros fotográficos realizados pelos professores mostram momentos de descontração vivenciados pelos discentes, durante atos simples como os de caminhar, subir em árvores, etc., por outro lado, alguns dos registros feitos pelos estudantes revelam a difícil realidade vivenciada cotidianamente por eles durante o percurso casa/escola/casa.

Revelam, por exemplo, a precariedade com que foi construída a ponte sobre o Rio Paraíba, com madeiras parafusadas e redes de nylon aos redores, para dar "segurança" a quem possa vir a atravessá-la. Como a ponte não suporta muito peso, geralmente, os alunos fazem a travessia de um lado para outro a pé, enquanto o ônibus espera-os ligado do outro lado.

No processo de seleção das fotos na sala de aula, um estudante relatou a precariedade dessa ponte: "[...] esse monte de menino em cima da ponte, mas se ela se torasse, hein? A gente ia cair tudinho dentro das águas do Rio São Francisco, ia parar lá no açude de Boqueirão." (Diego, 9 anos). Devido à chegada das 
SABERES E EXPERIÊNCIAS DE PRATICAS PEDAGÓGICAS NO CONTEXTO EDUCACIONAL

águas da transposição do Rio São Francisco, as águas passam pelo Rio Paraíba a alguns metros atrás da escola EMAAF. A ponte foi construída as pressas para possibilitar o acesso dos agricultores à cidade e dos alunos à escola.

Durante a realização da análise das fotografias, uma determinada imagem me despertou bastante atenção: o fardamento dos alunos expressa a seguinte frase "Formando cidadãos". Se formar cidadãos é uma das finalidades da Educação Nacional, segundo o Art. $2^{\circ}$ da Lei de Diretrizes e Bases da Educação Nacional n 9.394/96 (p. 8), me parece que a EMAAF está cumprindo com suas responsabilidades. Ilustramos essa questão, descrevendo o diálogo de dois estudantes da referida escola: "[...] Eita, olha eu e tio, aí na foto!" (Matheus, 9 anos). Os risos tomaram conta da sala e outro estudante logo se expressa orgulhoso: "Foi eu quem tirou essa foto!" (Alexandre, 7 anos).

\section{CONCLUSÃO}

A partir da experiência dessa prática pedagógica e dos seus resultados, percebemos que o trabalho com a fotografia na escola possibilita, tanto para professores quanto para estudantes, o despertar de um olhar mais sensível, aguçado e crítico, diante da realidade registrada e que para eles, antes, apresentava-se de modo banal, sem muita importância; e transforma o processo ensino-aprendizagem em algo prazeroso, vívido e reflexivo. Para Zóboli (2014, p.200), é fundamental que a tecnologia esteja a serviço do pedagógico.

Outro momento resultante desta pesquisa foi a impressão das fotografias e a montagem de um mural com as fotos, em uma das paredes do pátio da escola. As fotos ficaram expostas durante todo o ano letivo de 2017, e tiveram ampla visibilidade por todos os segmentos da instituição de ensino.

Por fim, diante do que aqui apresentamos, envolvendo Educação e Arte Fotográfica, podemos concluir que práticas pedagógicas dinâmicas como esta colaboram efetivamente para o sucesso do processo ensino-aprendizagem. 


\section{REFERENCIAS}

BRASIL. Lei de Diretrizes e Bases da Educação Nacional. Lei n 9.394/96. Brasília: Senado Federal, Coordenação de Edições Técnicas, 2017.

FREIRE, Paulo. Pedagogia da autonomia: saberes necessários à prática de educativa. São Paulo: Paz e Terra, 1996.

GONÇALVES, G.B.B. “Nucleação das escolas rurais.” In: OLIVEIRA, D.A.; DUARTE, A.M.C.; VIEIRA, L.M.F. Dicionário: trabalho, profissão e condição docente. Belo Horizonte: UFMG/Faculdade de Educação, 2010. CDROM. Disponível em < https://www.gestrado.net.br/pdf/149.pdf> Acesso em 19 jan. 2020.

NEVES, Lucilia de Almeida. Memória, história e sujeito: substratos da identidade. Revista História Oral, Fortaleza, n.3, 2000. Disponível em https://revista.historiaoral.org.br/index.php?journal=rho\&page=article\&op=view\&pat\%5B\%5D=25\&path\%5B\%5D=19> Acesso em 20 jan. 2020.

YOUNG, Michael. Para que servem as escolas? Educ. Soc., Campinas, vol. 28, n. 101, pp.1287-1302, set./dez. 2007. Disponível em https://www.cedes.unicamp. br> Acesso em 18 jan. 2020.

ZÓBOLI, Graziella. Práticas de ensino: subsídios para atividade docente. Rio de Janeiro: Wak Editora, 2014. 


\section{ANEXOS}

Figura 1 - Prof. João Evangelista e Turma do $2^{\circ}$ Ano da EMAAF, Sítio Madeira Camalaú/PB, 2017.

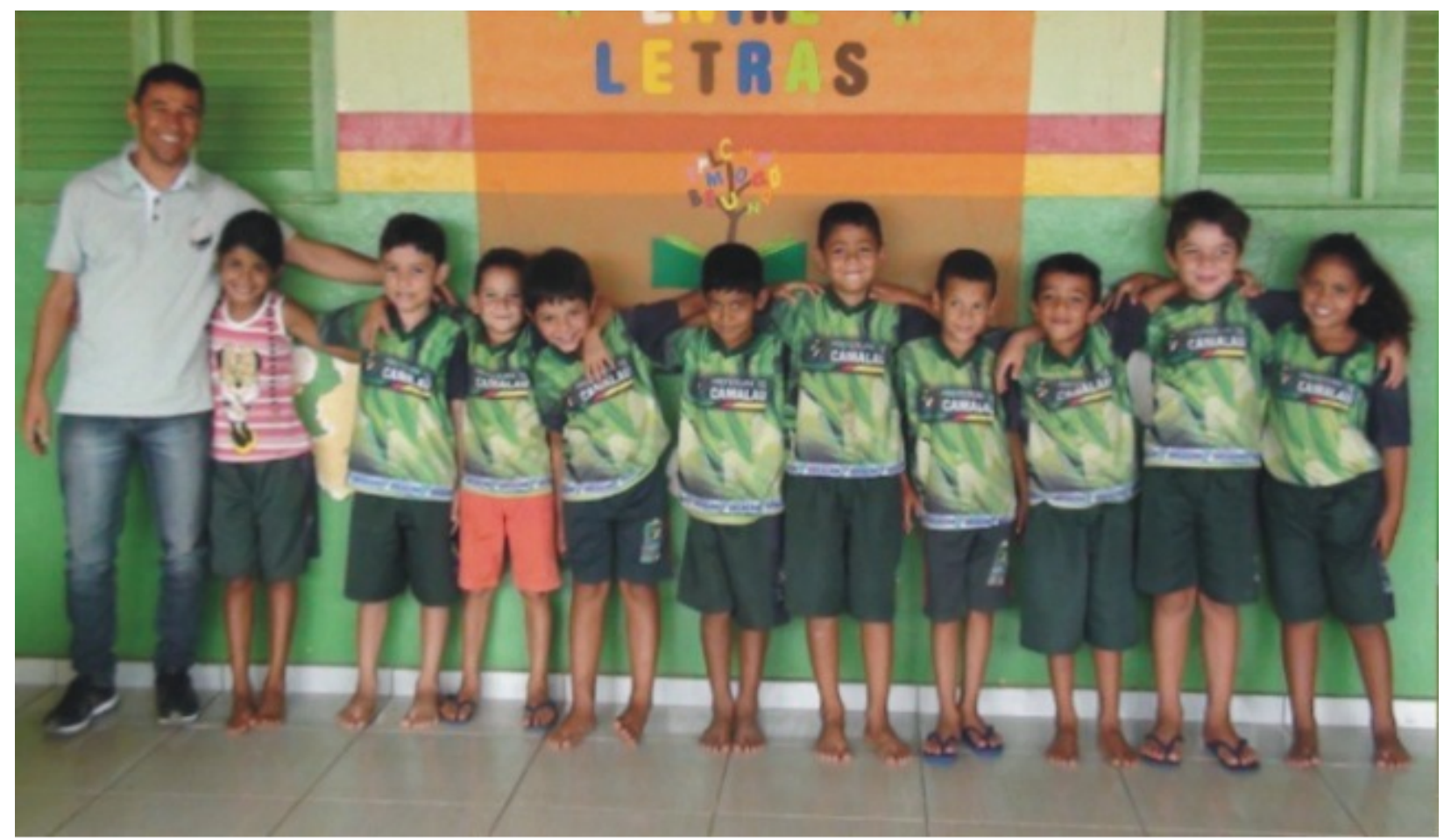

Fonte: Foto da Prof ${ }^{\mathrm{a}}$ Mere Girliane

Figura 2 - Prof. José Diones e Turma do $3^{\circ}$ Ano da EMAAF, Sítio Madeira Camalaú/PB, 2017.

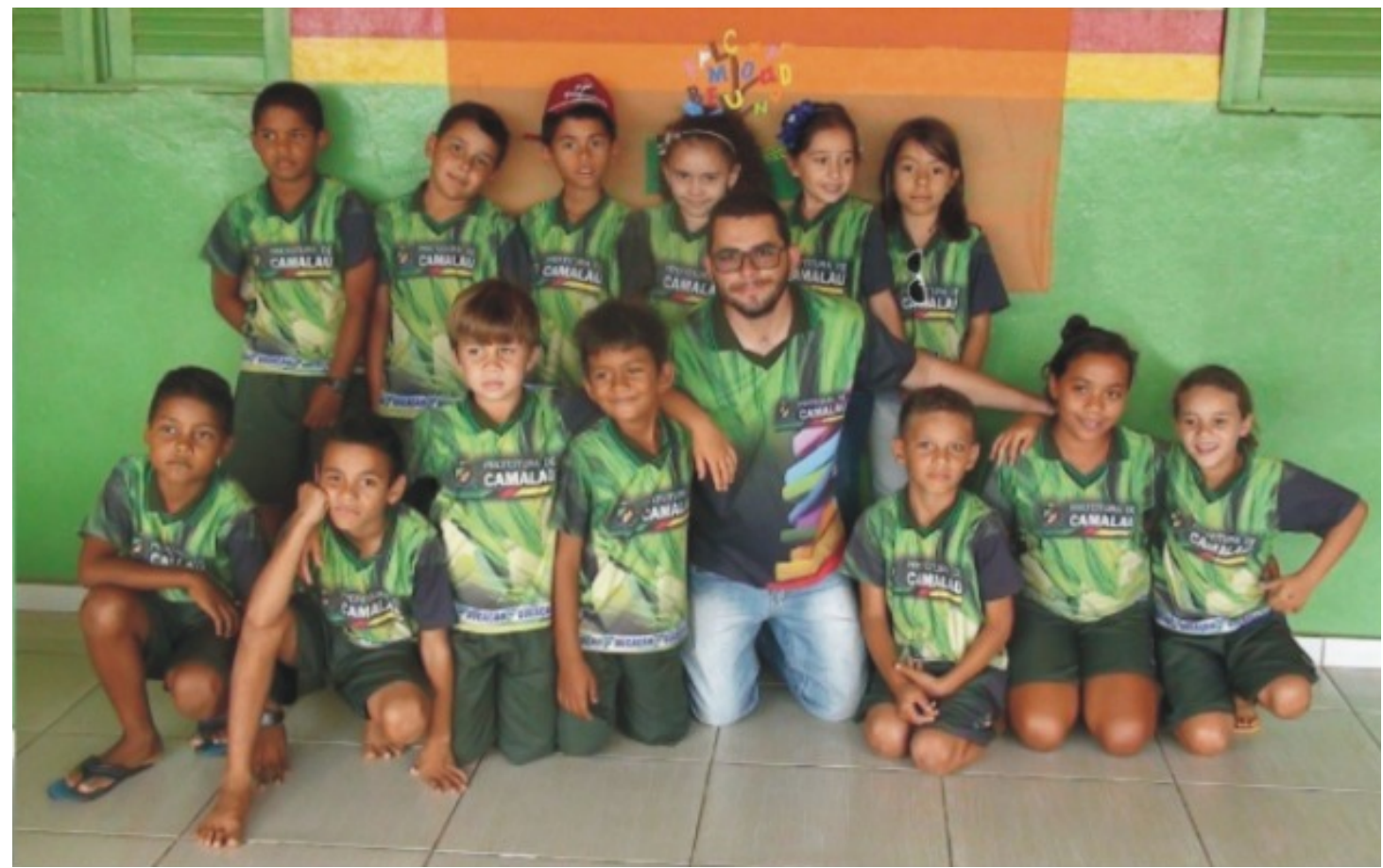

Fonte: Foto da Profa Mere Girliane 
Figura 3

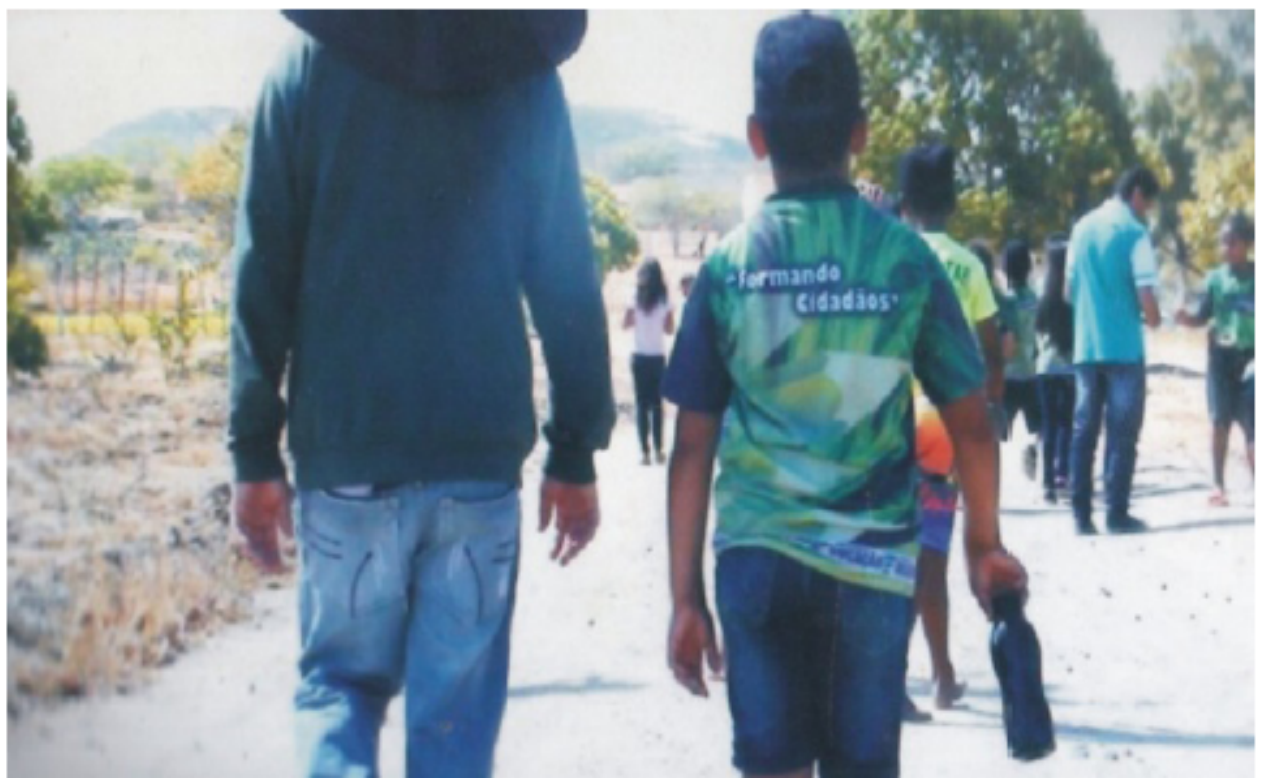

Fonte: Foto do aluno Alexandre, $2^{\circ} \mathrm{Ano}, 2017$.

Figura 4

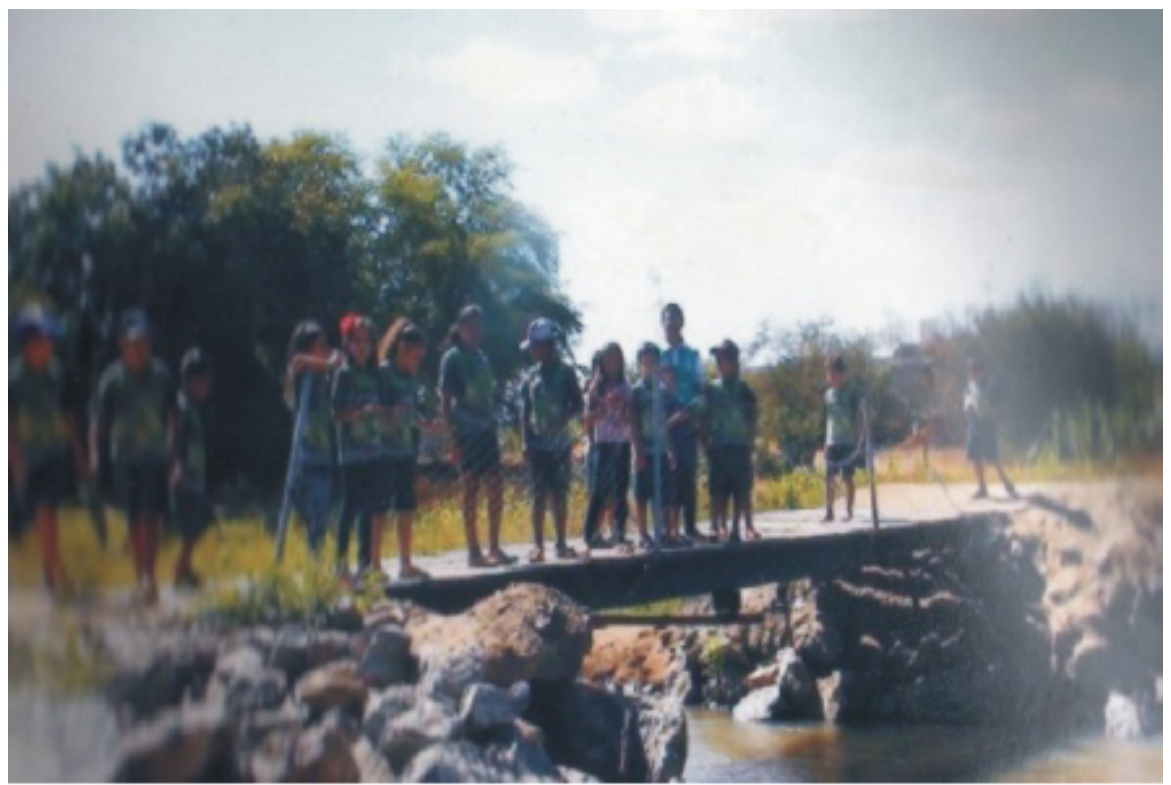

Fonte: Foto do aluno Diego, $3^{\circ}$ Ano, 2017. 
Figura 5

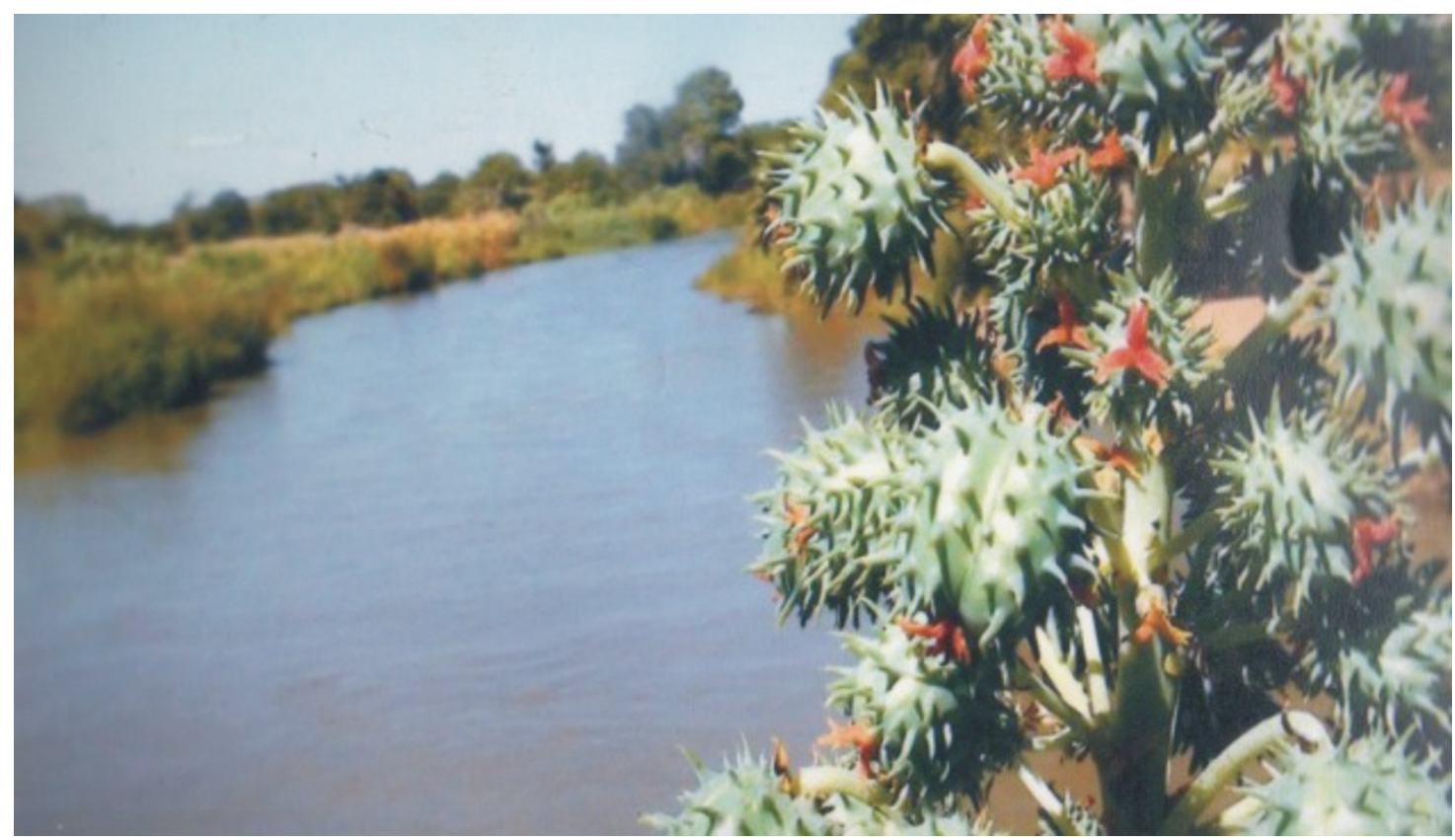

Fonte: Foto da aluna Samylle, $2^{\circ}$ Ano, 2017.

Figura 6

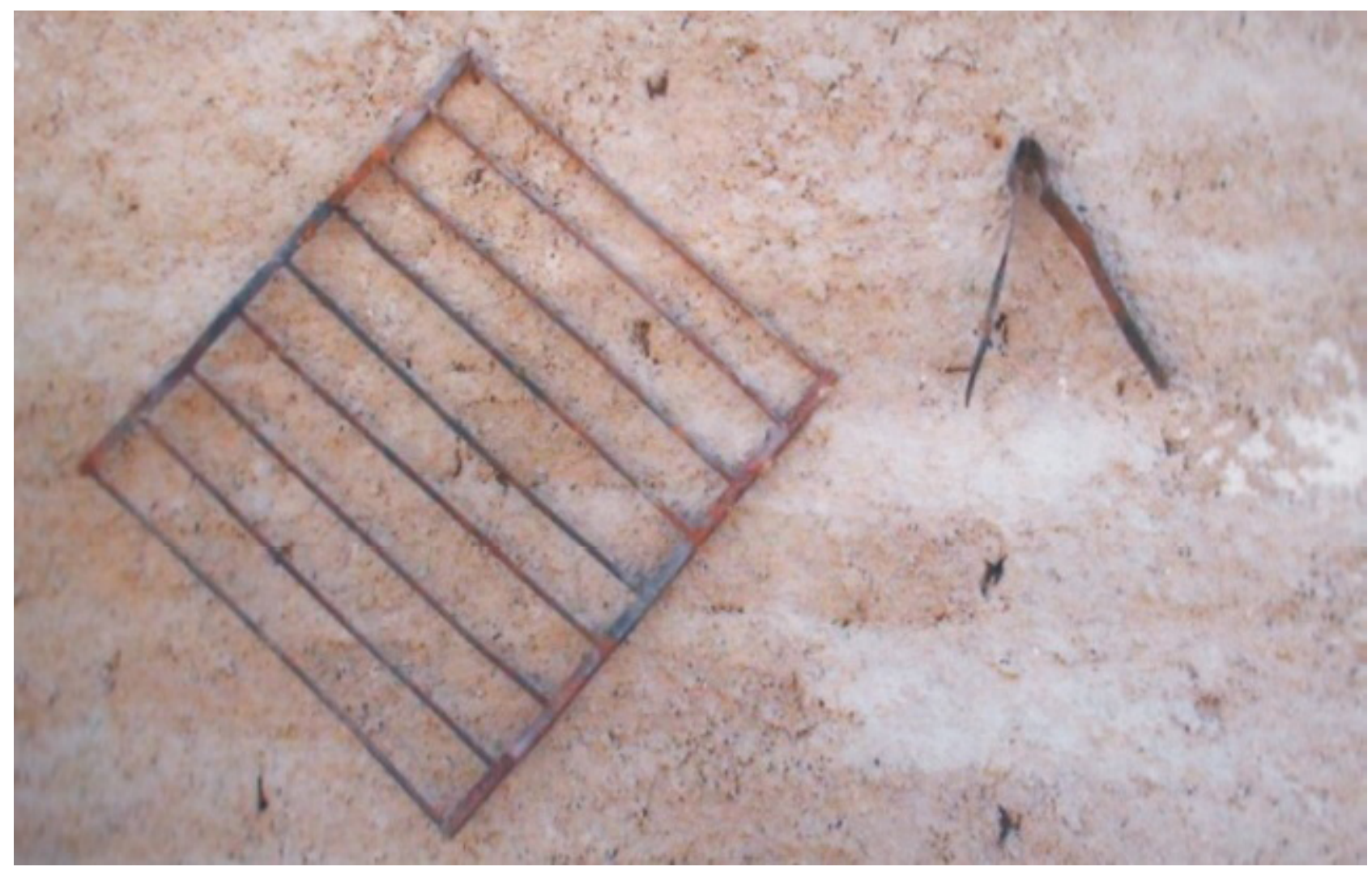

Fonte: Foto do aluno Rafael, $3^{\circ}$ Ano, 2017. 


\section{ЕDUCAÇÃO DO CAMPO:}

Figura 7

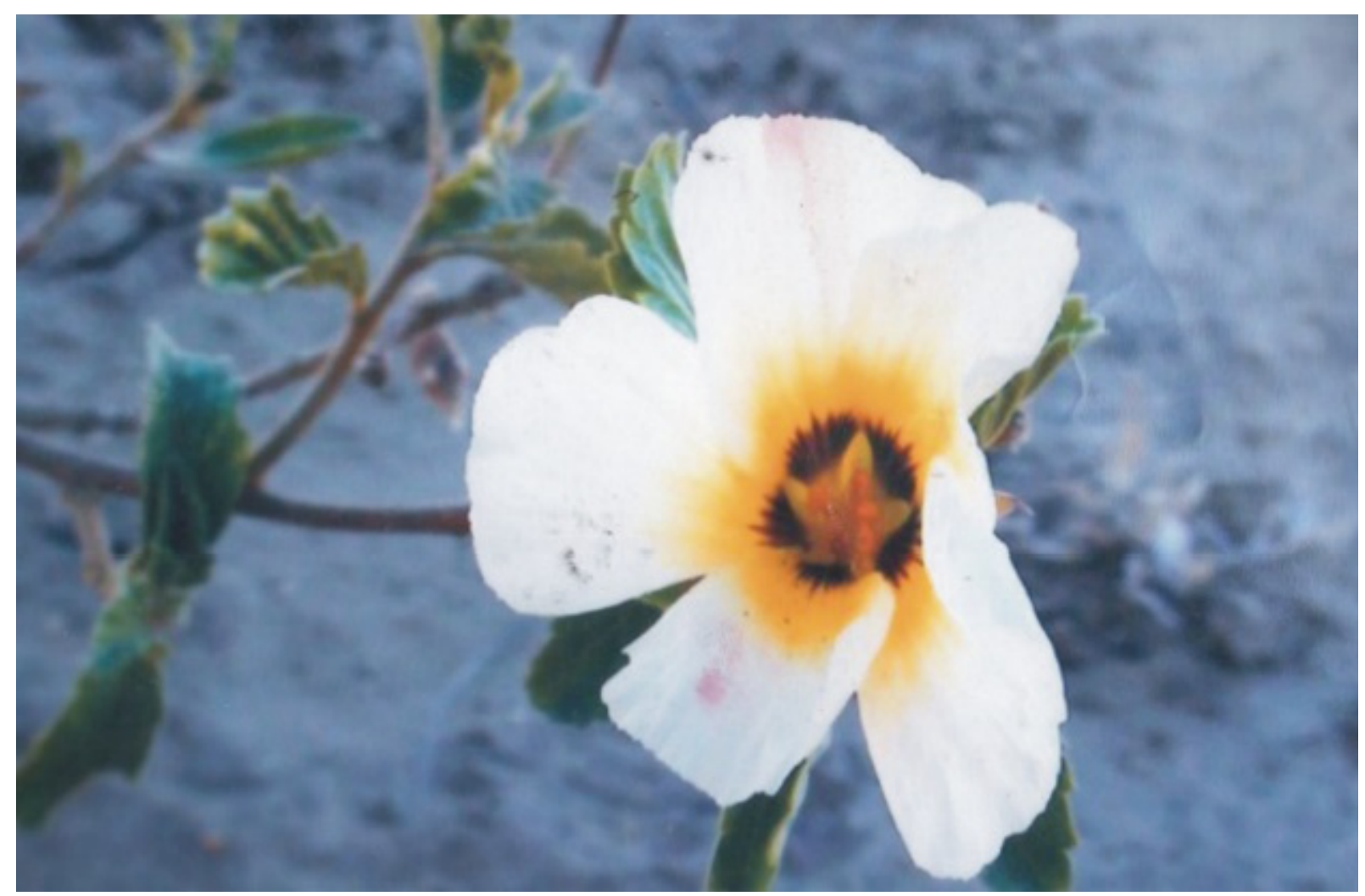

Foto da aluna Hevellyn, $2^{\circ}$ Ano, 2017.

Figura 8

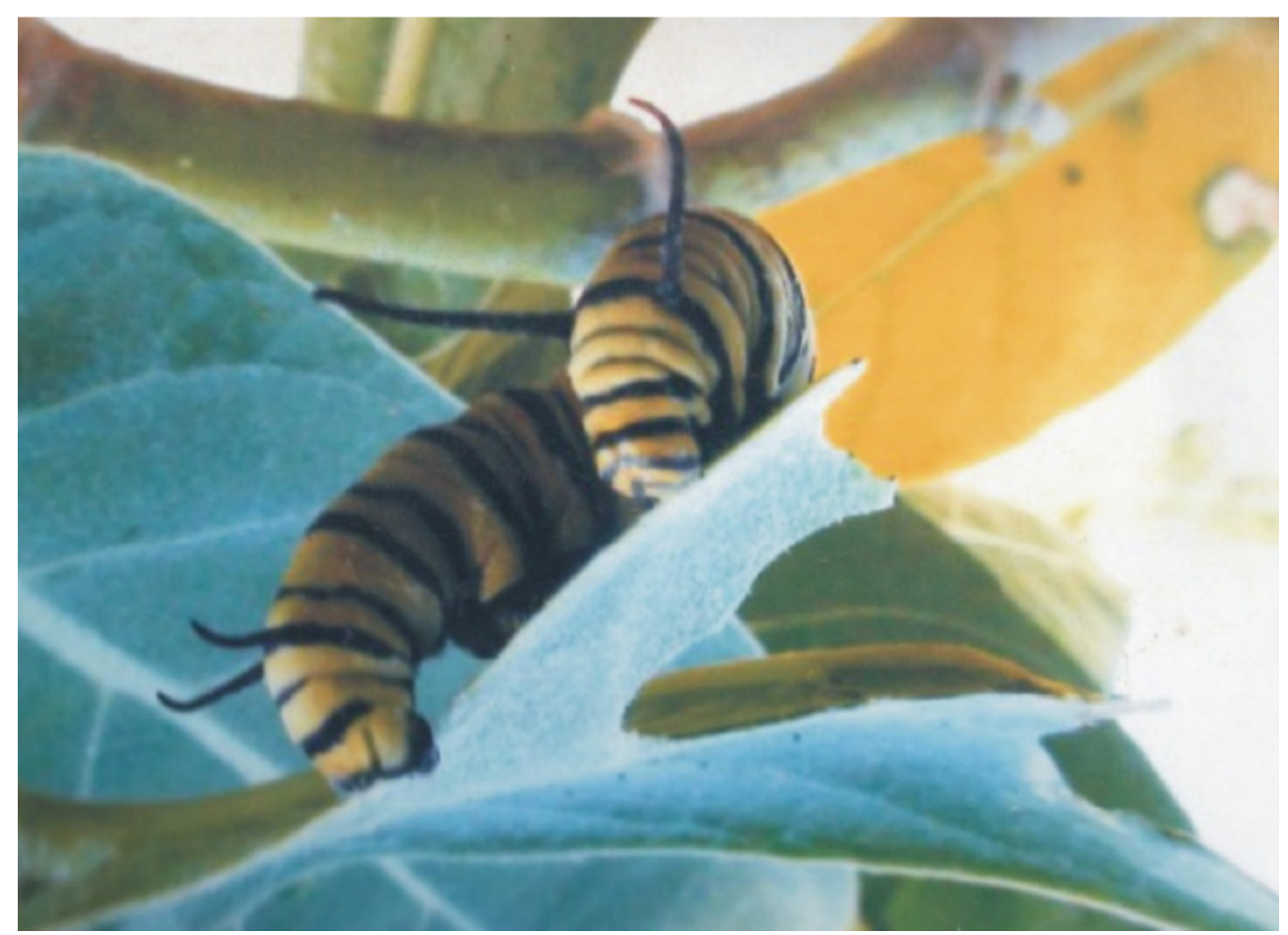

Fonte: Foto da aluna Stefanni, $3^{\circ}$ Ano, 2017. 
Figura 9

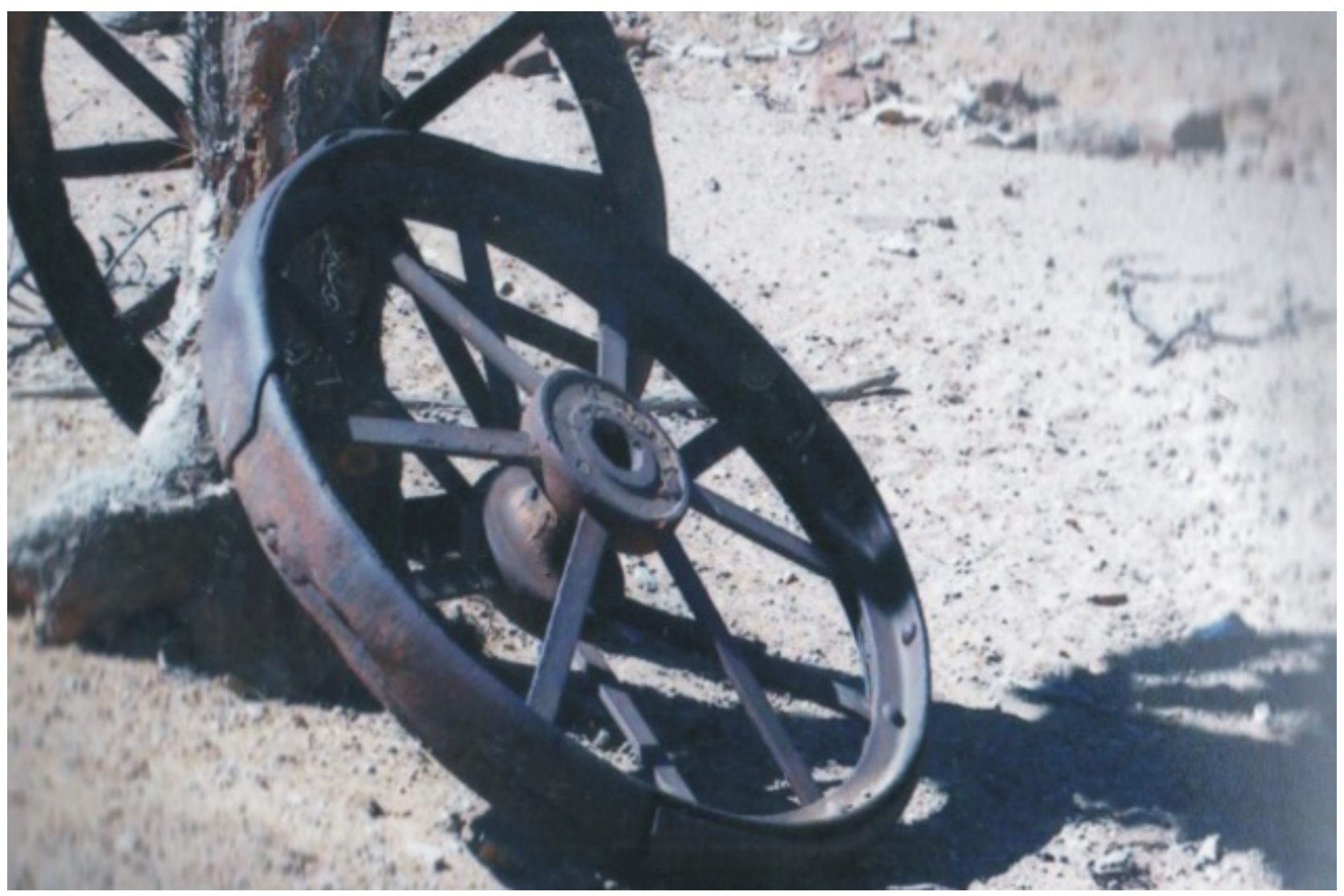

Fonte: Foto do aluno Alikis, $2^{\circ}$ Ano, 2017.

Figura 10

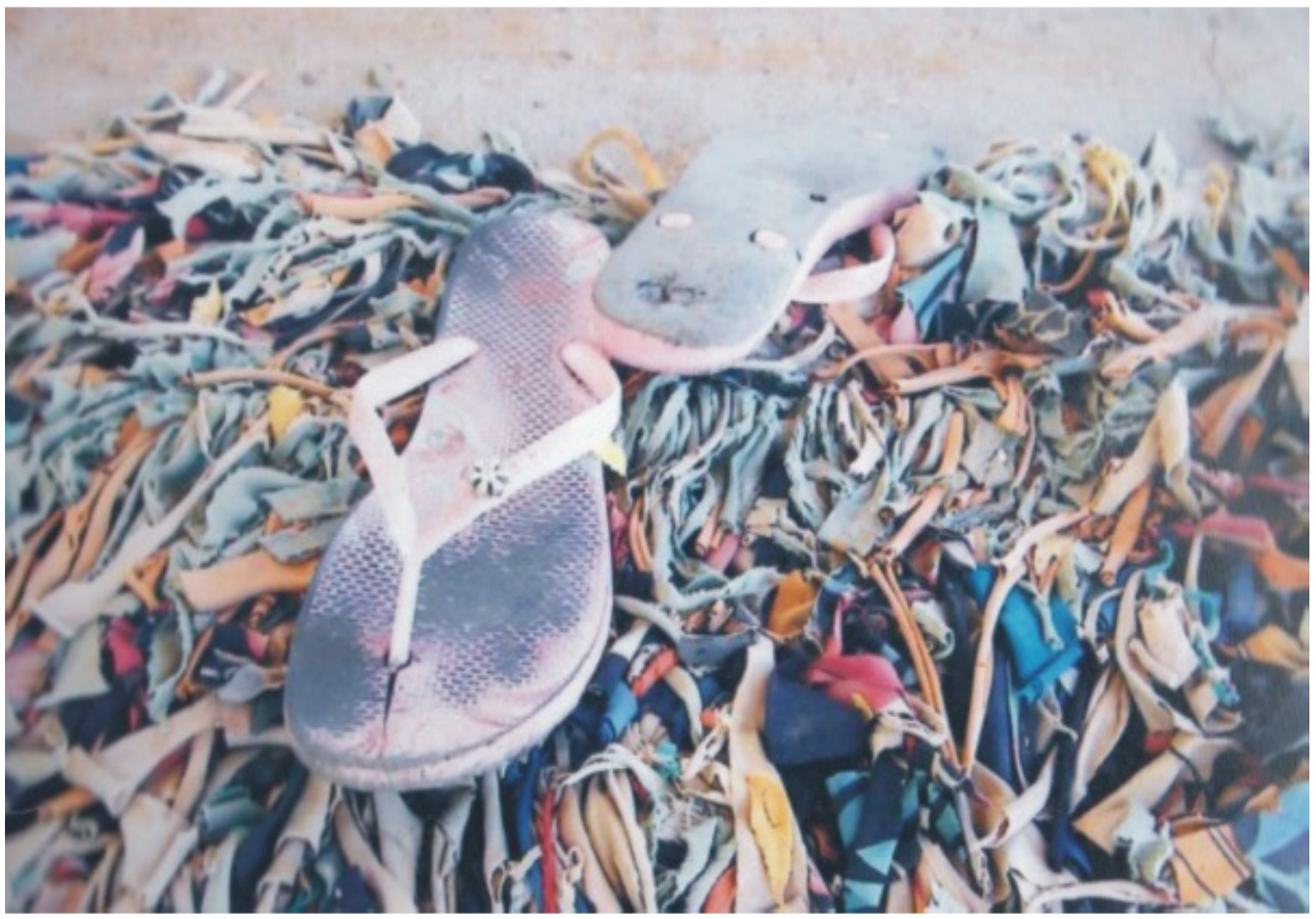

Fonte: Foto da aluna Clarice, $3^{\circ}$ Ano, 2017. 
Figura 11

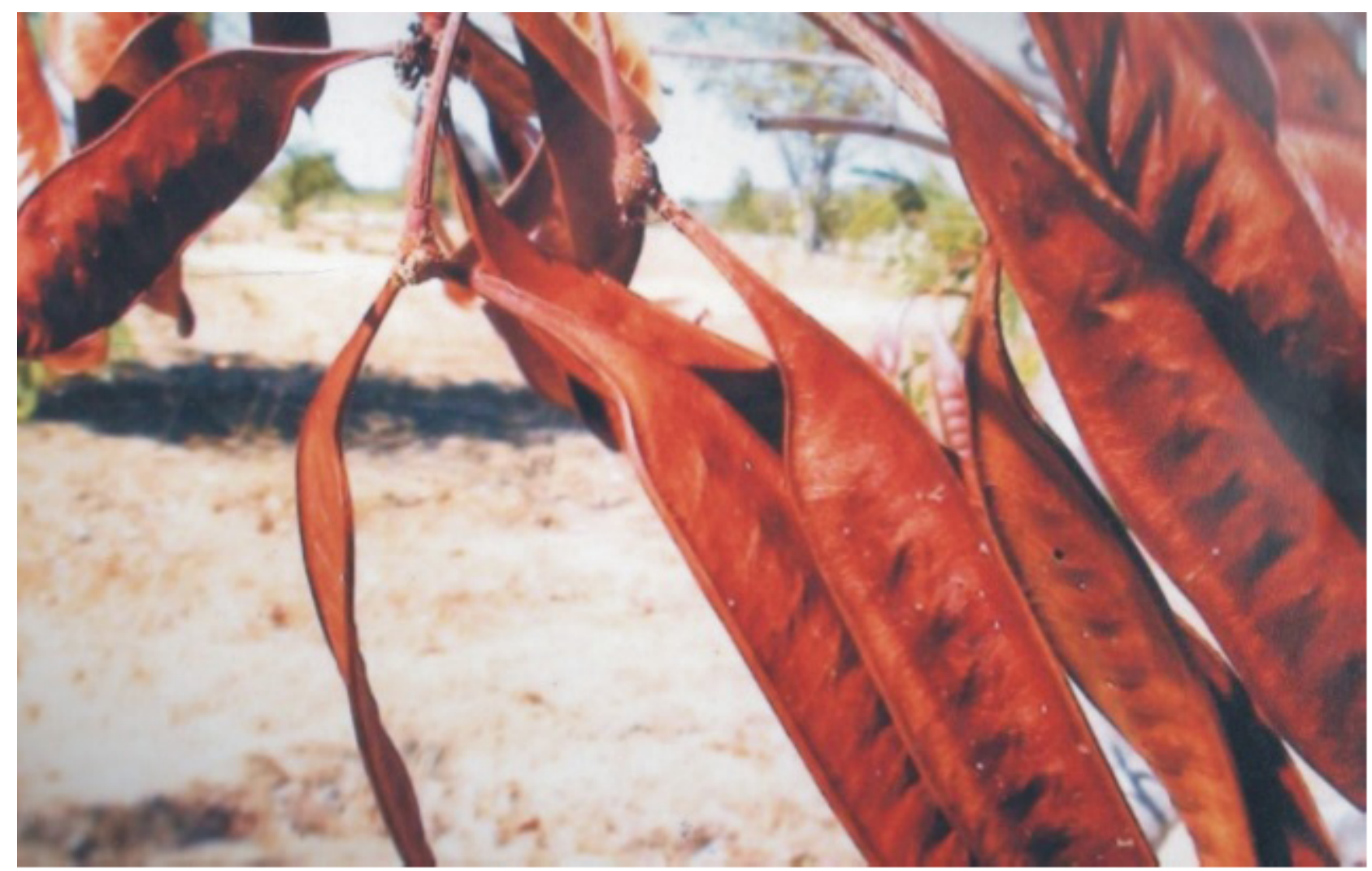

Fonte: Foto do aluno Michael, $2^{\circ}$ Ano, 2017.

Figura 12

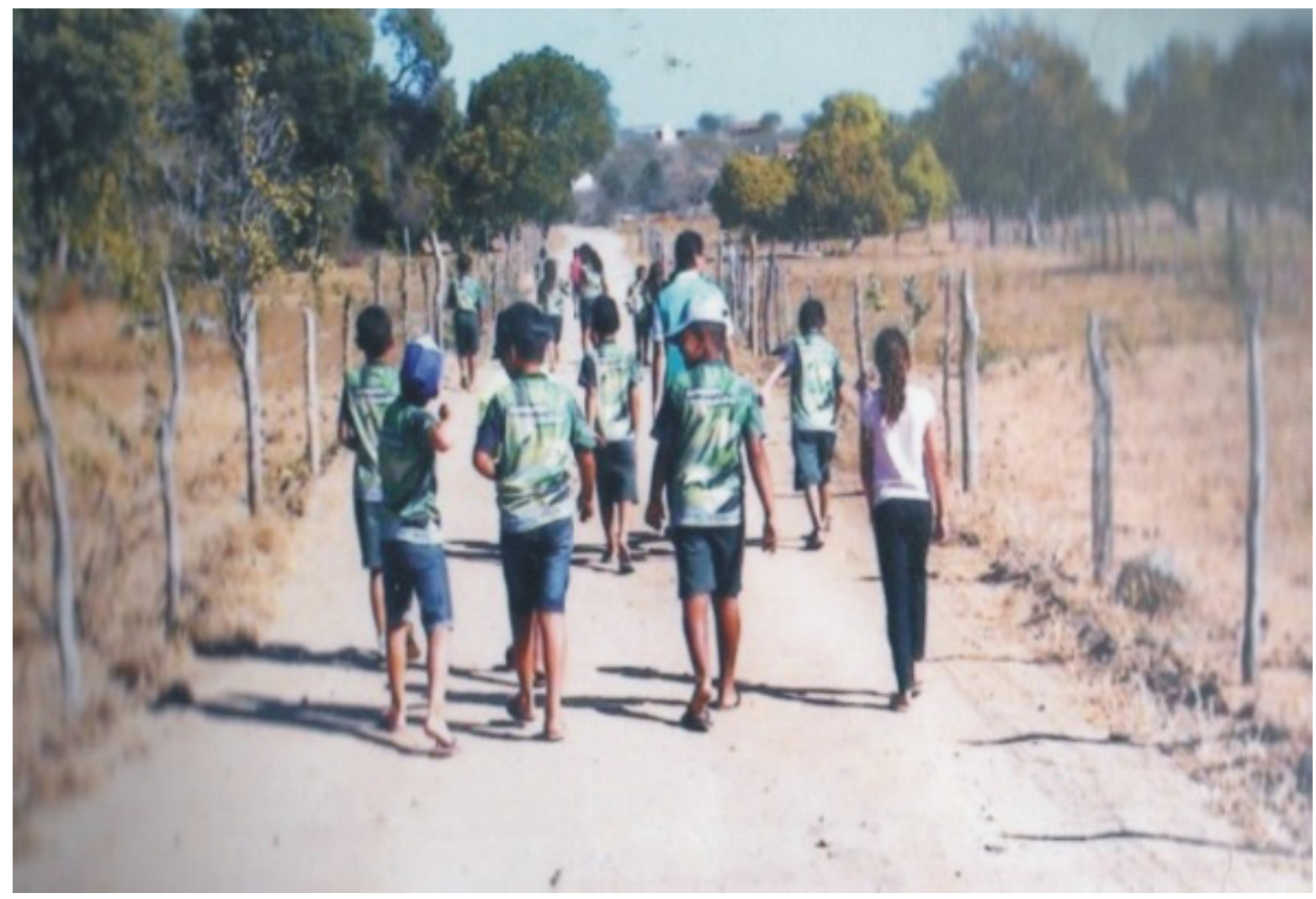

Fonte: Foto do aluno Eduardo, $3^{\circ} \mathrm{Ano}, 2017$. 
Figura 13

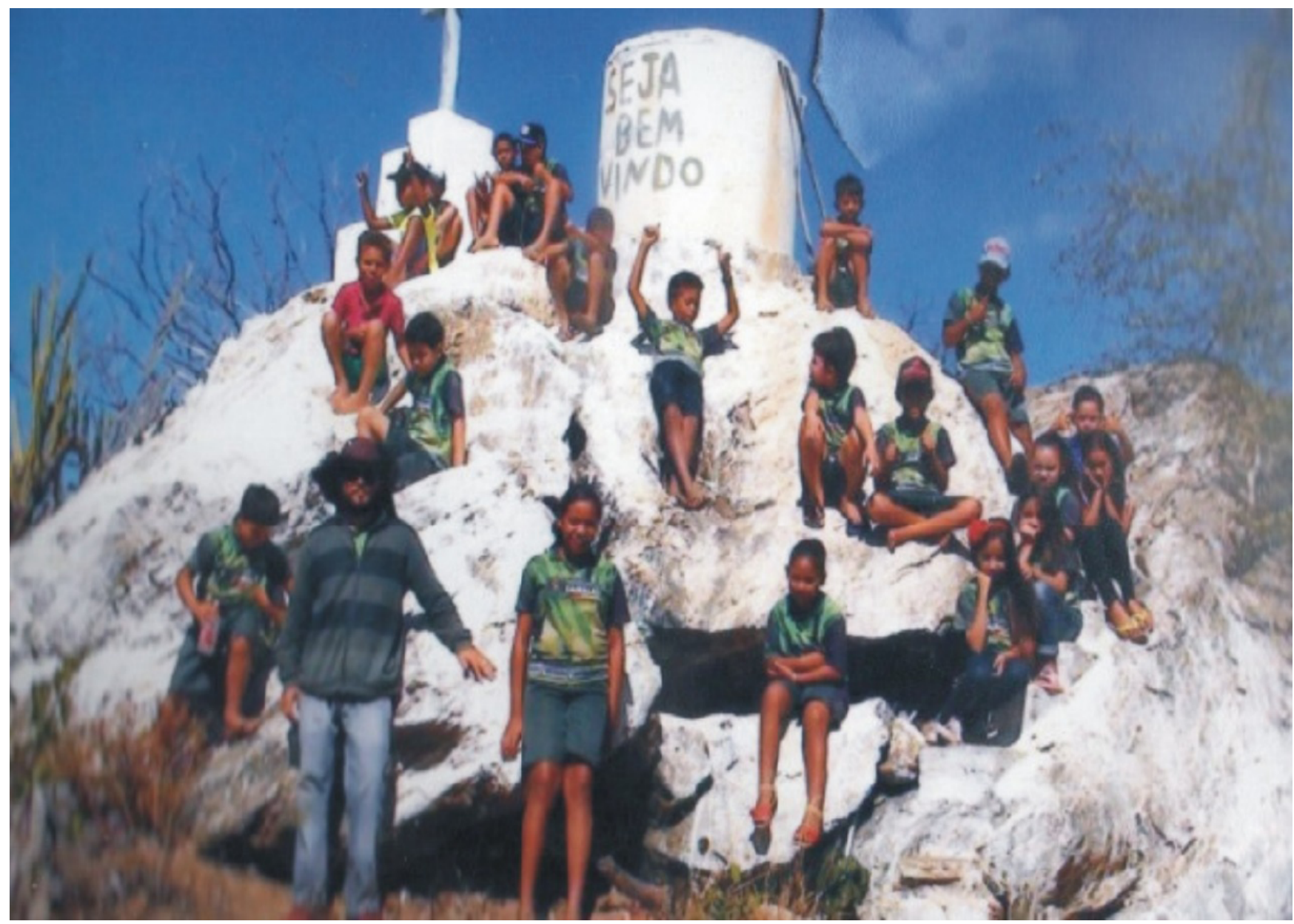

Foto do aluno Alexandre, $2^{\circ}$ Ano, 2017.

Figura 14

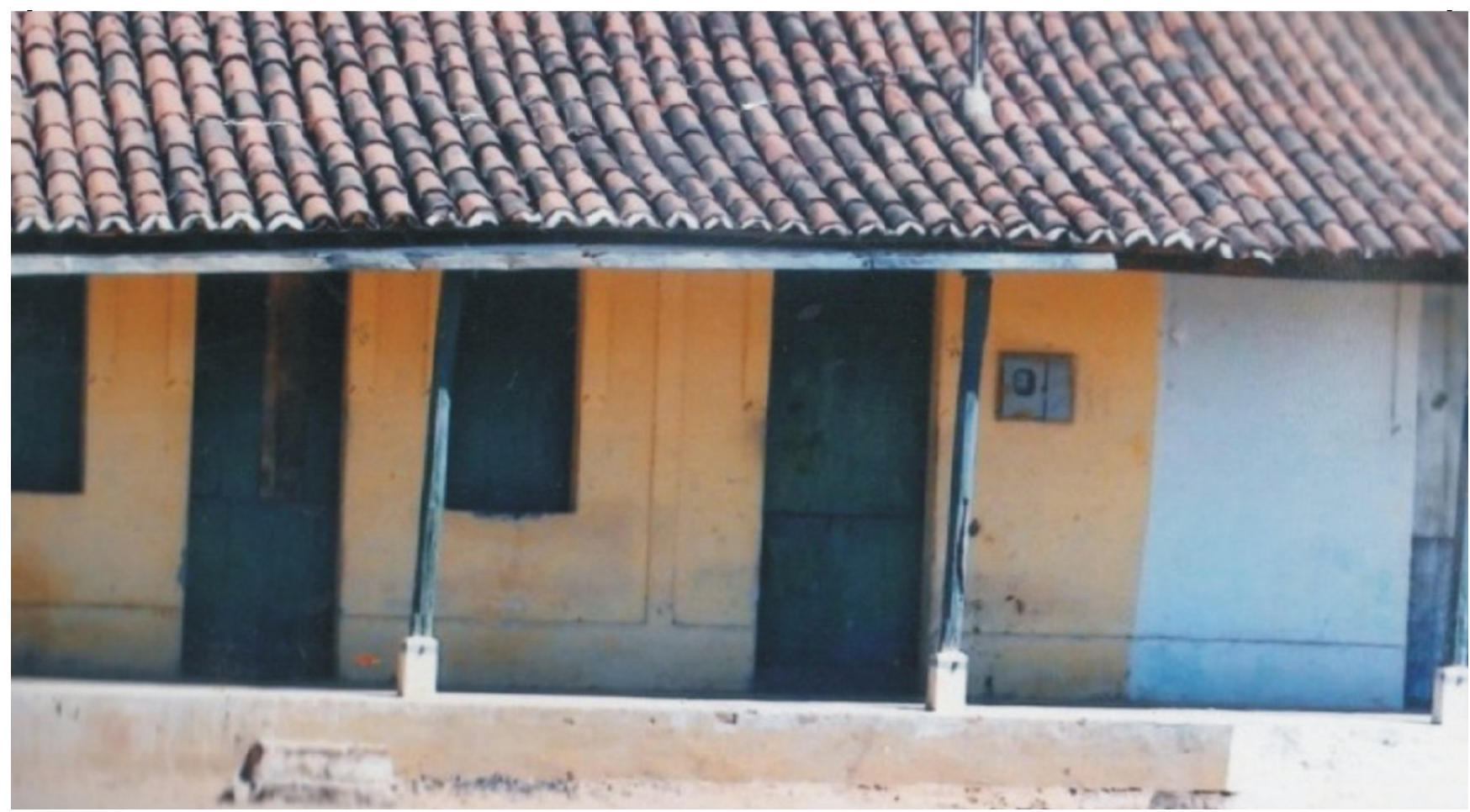

Foto do aluno Deivson, $3^{\circ}$ Ano, 2017. 

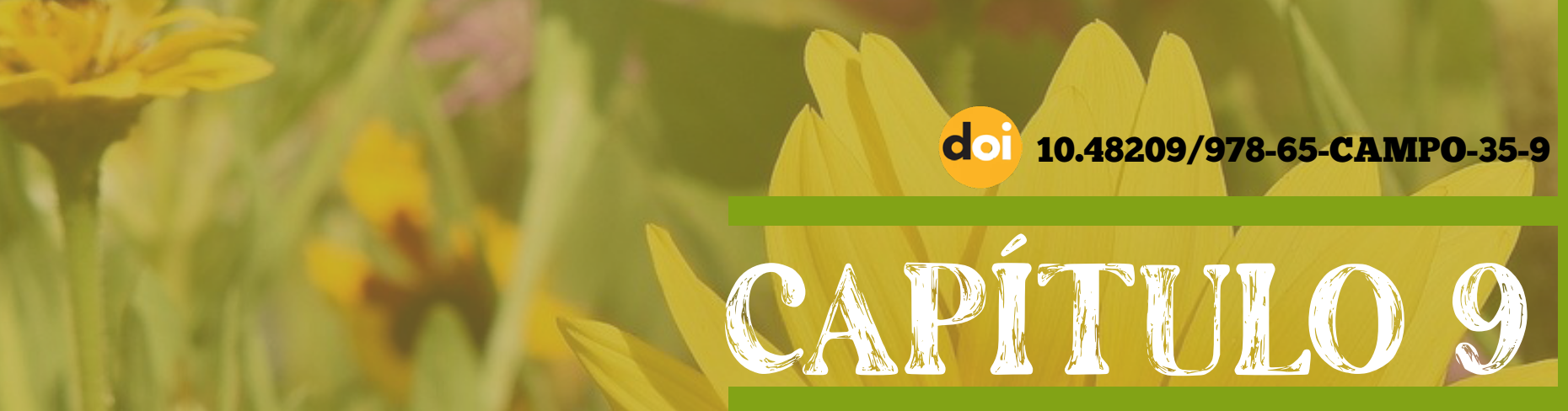

\section{REIÓOTO DO CORPO FUMANO:} MATEMHTICA MÃONA MASSA E CRIATHVA BM UMA ESCOLA DO CAMPO

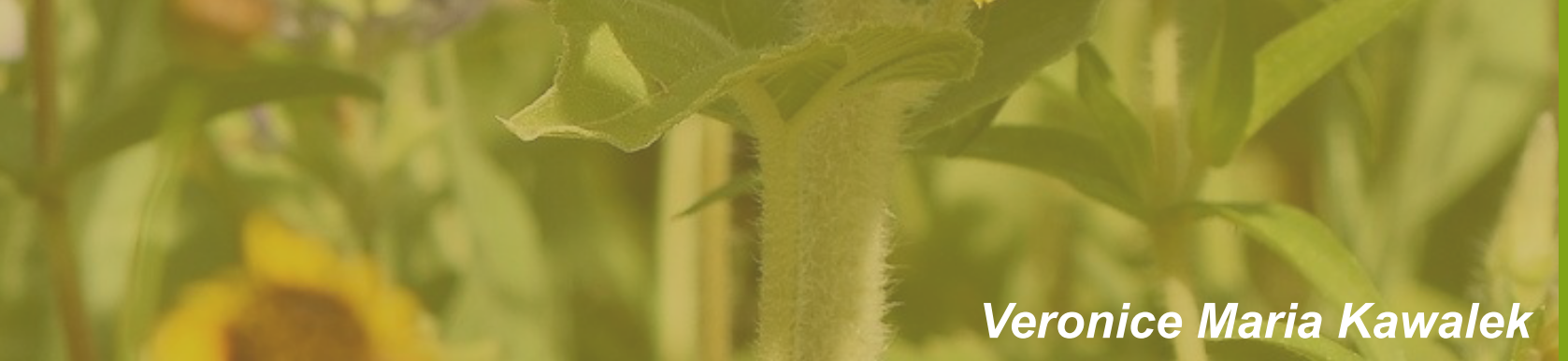

Soraia Stabach Ribas Ferrari dos Santos Eloiza Aparecida Silva Ávila de Matos

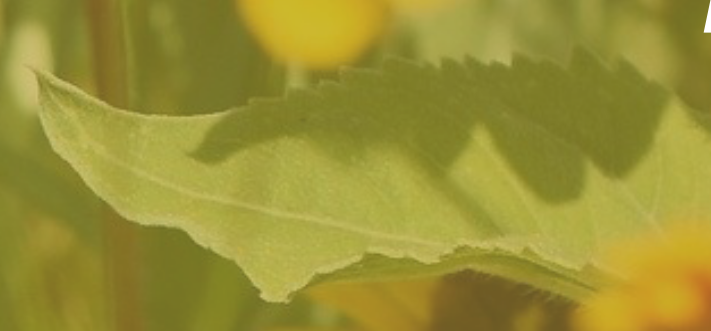

Marcos Vinicius Pereira Ribeiro 
SABERES E EXPERIÊNCIAS DE PRATTICAS PEDAGÓGICAS NO CONTEXTO EDUCACIONAL

\section{INTRODUÇÃ}

Ensinar matemática de maneira contextualizada e criativa no contexto das escolas do campo é um desafio, nesse sentido, a utilização de metodologias ativas de ensino pode ser um caminho para inovar. $O$ presente trabalho é fruto da experiência realizada com os alunos de sétimo e oitavo anos, em uma escola estadual do campo na cidade de Salto do Lontra, estado do Paraná. Essa atividade proporcionou a participação dos alunos como sujeito ativo no processo de aprendizagem ao desenvolver o projeto de construção do relógio medicinal do corpo humano.

A problemática que originou a presente pesquisa foi: Quais as contribuições da implementação de um relógio medicinal do corpo humano para o ensino de matemática na perspectiva da aprendizagem criativa em uma escola do campo? Para responder essa questão problema, realizou-se a pesquisa de referencial teórico bem como análise das potencialidades da utilização do relógio medicinal do corpo humano como instrumento de ensino de matemática em uma escola do campo.

A opção pelo tema se originou em uma elaboração de plano de trabalho docente, no qual designa o conteúdo de cálculos de grandezas, área e perímetro, usando as operações aritméticas, assim, optou-se pela linha da utilização da matemática na realização de um horto medicinal como alternativa para os educandos adquirirem conhecimentos, além de que, as plantas medicinais possibilitam uma abordagem interdisciplinar com a disciplina de ciências, estabelecendo conexões entre fundamentos e conceitos nas diversas áreas do saber.

A matemática está presente na vida do ser humano desde os primórdios, pois era utilizada para poder contabilizar a quantidade de cereais ou de gado que cada sujeito possuía conforme destaca D’Ambrósio (1997, p. 120). Através do horto medicinal é possível criar consciência de matemática por meio de proporção de medida, tempo e espaço, ademais, favorece a formação da cidadania, incluindo, a capacidade de tomada de decisão por meio de uma abordagem que 
articule ciência, tecnologia e sociedade, contribuindo para aproximar o conhecimento da comunidade, valorizar o conhecimento popular e validá-lo por meio de pesquisa.

A metodologia ativa proporciona que as aulas práticas, tornem os alunos protagonistas se envolvendo na construção do conhecimento, ampliando a capacidade de resolver problemas e, também, desenvolvem habilidades, além de compreender conceitos básicos. Segundo Krasilchik (2008) as aulas práticas desempenham funções que permitem o contato direto com os fenômenos, manipulando e observando, entretanto, enfrentam os resultados não previstos, desafiando sua imaginação e raciocínio, com isso, os alunos compreendem processos tornando a prática uma modalidade com grande potencial de ensino e aprendizagem.

A pesquisa caracteriza-se como uma pesquisa do tipo intervenção pedagógica de cunho qualitativo e de natureza aplicada. A pesquisa do tipo intervenção pedagógica caracteriza-se como uma pesquisa na qual é realizado o planejamento e aplicação de intervenções que visam a melhoria no processo de ensino e de aprendizagem( DAMIANI et. al, 2013).

\section{REFERENCIAL TEÓRICO}

O referencial teórico está fundamentado na interface: ensino de matemática no contexto das escolas do campo e relógio medicinal do corpo humano. $A$ Educação do campo é uma modalidade de ensino que tem como objetivo a educação de crianças, jovens e adultos que vivem no campo. No estado do Paraná, as Diretrizes Curriculares da Educação do Campo configuram-se "um conceito político ao considerar as particularidades dos sujeitos e não apenas sua localização espacial e geográfica" (PARANÁ, 2006, p.24), sendo que o

"que caracteriza os povos do campo é o jeito peculiar de se relacionarem com a natureza, o trabalho na terra, a organização das atividades produtivas, mediante mão-de-obra dos membros da família, cultura e valores que enfatizam as relações familiares e de vizinhança" (...) (PARANÁ, 2006, p.24). 
SABERES E EXPERIÊNCIAS DE PRATICAS PEDAGÓGICAS NO CONTEXTO EDUCACIONAL

A Lei $n^{\circ}$ 9.394, de 20 de dezembro de 1996, dispõe sobre as Diretrizes e Bases da Educação Nacional (LDB). O artigo n²8 refere-se à educação básica voltada para a população que reside na área rural, em que emerge a necessidade de promover adaptações voltadas às peculiaridades de cada região,principalmente aos:

I - Conteúdos curriculares e metodologias apropriadas às reais necessidades e interesses dos alunos da zona rural;

II - Organização escolar própria, incluindo adequação do calendário escolar às fases do ciclo agrícola e às condições climáticas;

III - adequação à natureza do trabalho na zona rural. (BRASIL, 1996, p. 11).

Mediante a colocação da LDB torna-se necessário ressignificar a Educação do Campo, criando significado e demonstrando a utilidade dos assuntos trabaIhados em sala para o dia a dia dos alunos. Entretanto, para que isso se efetive é necessário que o currículo e as metodologias sejam alterados de acordo com as necessidades de cada lugar e sociedade.É importante valorizar e refletir sobre a experiência cotidiana dos alunos, pois o processo de reapropriação do saber comum diante de uma base científica proporciona surgimento de novas indagações, no qual o conhecimento é construído. (CALDART, 2008).

Para que a escola no campo se torne cada vez mais do campo, é preciso iniciar um processo gradativo de pertencimento, de aproximação da escola e de seus sujeitos com a comunidade local. O intuito é fazer a relação entre o conhecimento acadêmico, o conhecimento escolar e o conhecimento popular. (ARAUJO, 2011). Mas acima de tudo, é preciso ter cuidado para não cair na "relativização do conhecimento", não saindo do senso comum. (CALDART, 2008).

No que tange o ensino de matemática nas escolas do campo, entende-se que matemática é matemática em qualquer lugar, o que muda é como é ensinada de acordo com a realidade em que está inserida, logo, não existe uma matemática própria do campo, mas, pode-se usar métodos diferentes para ensiná-la nesse contexto (SACHS, 2018). Desta forma, um dos possíveis caminhos para o ensino de matemática no contexto das escolas do campo é a contextualização. 


\section{EDUCAÇÃO DO CAMPO:}

SABERES E EXPERIÊNCIAS DE PRATTICAS PEDAGÓGICAS NO CONTEXTO EDUCACIONAL

Tudo o que está relacionado e em volta do sujeito da escola do campo é notório a presença da matemática como as casas, as plantações, a escola, o tempo de chuva é medida que a terra absorveu em milímetros, nas formas e comprimentos de cada objeto e em outras dimensões. De acordo com D’Ambrósio (2002) destaca que:

Indivíduos e povos têm, ao longo de suas existências e ao longo da história, criado e desenvolvido instrumentos de reflexão, de observação, instrumentos materiais e intelectuais [que chamo de ticas] para explicar, entender, conhecer, aprender para saber fazer [que chamo de matema] como resposta a necessidades de sobrevivência e de transcendência em diferentes ambientes naturais, sociais e culturais [que chamo etnos]. (D’AMBRÓSIO, 2002, p. 60).

O autor demonstra que cada ser humano, cada indivíduo constrói seu conhecimento de acordo com a sua realidade vivenciada, assim, os alunos da escola do campo, necessitam de algo mão na massa para efetivarem o aprendizado. Conforme os estabelece Parâmetros Curriculares Nacionais (PCN) (BRASIL, 1999): "A matemática ajuda a estruturar o pensamento e o raciocínio dedutivo, além de ser uma ferramenta para tarefas específicas em quase todas as atividades humanas." Assim se torna cabível proporcionar uma aprendizagem matemática frente a realidade em que o aluno está inserido, para que este consiga compreender e entender que a disciplina de matemática não é distante e nem sem utilidade no seu cotidiano. É possível constatar o caráter formativo da disciplina quando se destaca que:

Em seu papel formativo, a matemática contribui para o desenvolvimento de processos de pensamento e a aquisição de atitudes, cuja utilidade e alcance transcendem o âmbito da própria matemática, podendo formar no aluno a capacidade de resolver problemas genuínos, gerando hábitos de investigação, proporcionando confiança e desprendimento para analisar e enfrentar situações novas, propiciando a formação de uma visão ampla e científica da realidade, a percepção da beleza e da harmonia, o desenvolvimento da criatividade e de outras capacidades pessoais. (BRASIL, 1999, p. 251).

É preciso que o professor consiga ultrapassar as barreiras e proporcionar os conteúdos dinâmicos, estimulando a criatividade e o interesse pela disciplina. 
Freire (1974), reforça que o aprendizado acontece e se efetiva no convívio social:

É preciso que a educação esteja em seus programas em seus métodos, adaptadas ao fim que se persegue: permitindo chegar a ser sujeito, construir-se como pessoa e transformar o mundo e estabelecer com os outros homens relações de reciprocidade, fazer a cultura e a história. (FREIRE, 1974, p. 59).

Existe uma variedade de alternativas possíveis para se trabalhar a matemática na escola de campo, o docente precisa se atentar para deixar claro aos alunos que a matemática ensinada e aprendida na sala de aula é a mesma matemática que seu pai ou mãe, seus avós, tias, primos e demais integrantes da sua família, utilizam em sua propriedades rurais na realização de plantio, soma da produção colhida, nas medidas utilizadas dentro de casa como litros, proporções de contabilidade entre gastos e ganhos na lavoura. Essa realidade na maior parte das vezes, fica desconectada da sala de aula, não fazendo sentido para o aluno aprender aquela disciplina, conforme destaca Sadovsky (2007):

A Matemática, não só no Brasil, é apresentada sem vínculos com os problemas que fazem sentido na vida das crianças e dos adolescentes. Os aspectos mais interessantes da disciplina, como resolver problemas, discutir ideias, checar informações e ser desafiado, são pouco explorados na escola. $O$ ensino se resume a regras mecânicas que ninguém sabe, nem o professor, para que servem. (SADOVSKY, 2007, p.8).

É possível encontrar na literatura muitas teorias que sustentam aos professores de matemática na escola de campo, porém, na prática é mais confortável utilizar os livros didáticos ofertados aos alunos, do que criar alternativas e propor métodos diversificados de ensino que priorizem o saber e oportunize que o aluno seja protagonista da construção de sua aprendizagem, levando em consideração o entorno ao qual este pertence.

Uma maneira de contextualizar o ensino de matemática realizado nesta pesquisa, foi através da construção de um relógio medicinal do corpo humano, como explicam Veloso, Wermann, Fusiger (2005):

Refere-se à construção de Hortos Medicinais em forma de Relógio, onde cada hora representa uma parcela correspondente a um órgão do corpo humano. Em cada parcela, são cultivadas as Plantas Medicinais de uso 
SABERES E EXPERIÊNCIAS DE PRATICAS PEDAGÓGICAS NO CONTEXTO EDUCACIONAL

referendado pela ciência e que auxiliam nos transtornos de saúde do órgão representado. (VELLOSO; WERMANN; FUSIGER, 2005, p. 5).

De acordo com a Medicina Chinesa, o corpo humano compõe-se em microcosmo (o corpo humano considerado como pequenos universos) que representam as leis da natureza, quando observa-se a circulação de energia pelos meridianos principais. Cada um desses meridiano é parte integrante da Grande Circulação do organismo que apresenta duas horas de atividade máxima diária, horário determinado do dia em que, o órgão correspondente ao meridiano se manifesta (funcionando involuntariamente), e para desfrutar da eficácia dos resultados terapêuticos, os horários devem ser controlados e observado para a ingestão das plantas medicinais correspondentes.

Assim sendo, o relógio do corpo humano é composto por 12 canteiros, no qual cada canteiro corresponde a um órgão que está no auge do seu funcionamento, sendo eficaz consumir determinada planta medicinal naquele momento (AVILA et. al, 2021). A energia vital percorre o circuito por inteiro dentro de um ritmo, iniciando no meridiano do pulmão, obedecendo ao percurso, demonstrado de maneira detalhada no Quadro 1.

Quadro 1: Descrição do funcionamento do relógio do corpo humano

\begin{tabular}{|c|c|c|c|}
\hline Horário & Órgão & Ação principal & $\begin{array}{c}\text { Planta } \\
\text { medicinal }\end{array}$ \\
\hline $\begin{array}{l}\text { 03h00min } \\
\text { 05h00min }\end{array}$ & Pulmão & $\begin{array}{l}\text { o pulmão tem seu pique máximo (razão das } \\
\text { crises de tosse, asma, serem quase sempre } \\
\text { nesse horário da madrugada); é o momento } \\
\text { em que esse órgão faz sua limpeza; }\end{array}$ & $\begin{array}{l}\text { Pulmonária } \\
\text { Violeta de } \\
\text { Jardim }\end{array}$ \\
\hline $\begin{array}{l}\text { 05h00min } \\
07 \mathrm{~h} 00 \mathrm{~min}\end{array}$ & $\begin{array}{c}\text { Intestino } \\
\text { Grosso }\end{array}$ & $\begin{array}{l}\text { horário do intestino grosso, momento para } \\
\text { realizar a evacuação desse órgão; qualquer } \\
\text { pessoa que estiver em equilíbrio, perto das } \\
7 \text { horas, fará a eliminação dos resíduos } \\
\text { alimentares; }\end{array}$ & $\begin{array}{c}\text { Linhaça } \\
\text { Tansagem }\end{array}$ \\
\hline $\begin{array}{l}\text { 07h00min } \\
\text { 09h00min }\end{array}$ & Estômago & $\begin{array}{l}\text { horário do estômago: é o horário da Grande } \\
\text { Alimentação, em que o corpo pede e aceita } \\
\text { melhor e naturalmente os alimentos; }\end{array}$ & $\begin{array}{c}\text { Manjericão } \\
\text { Hortelã }\end{array}$ \\
\hline
\end{tabular}


EDUCAÇÃO DO CAMPO:

SABERES E EXPERIÊNCIAS DE PRATICAS PEDAGÓGICAS NO CONTEXTO EDUCACIONAL

\begin{tabular}{|c|c|c|c|}
\hline $\begin{array}{l}09 \mathrm{~h} 00 \mathrm{~min} \\
11 \mathrm{~h} 00 \mathrm{~min}\end{array}$ & $\begin{array}{l}\text { baço e } \\
\text { pâncreas }\end{array}$ & $\begin{array}{c}\text { horário do baço e pâncreas, onde são } \\
\text { produzidos ácidos para a digestão } \\
\text { do almoço; }\end{array}$ & $\begin{array}{l}\text { Pariparoba } \\
\text { Salsinha }\end{array}$ \\
\hline $\begin{array}{l}11 \mathrm{~h} 00 \mathrm{~min} \\
13 \mathrm{~h} 00 \mathrm{~min}\end{array}$ & Coração & $\begin{array}{l}\text { horário do coração, a circulação ativa-se } \\
\text { bastante; }\end{array}$ & $\begin{array}{l}\text { Alecrim } \\
\text { Gervão }\end{array}$ \\
\hline $\begin{array}{l}\text { 13h00min } \\
15 \mathrm{~h} 00 \mathrm{~min}\end{array}$ & $\begin{array}{l}\text { Intestino } \\
\text { Delgado }\end{array}$ & $\begin{array}{l}\text { entra em funcionamento o intestino } \\
\text { delgado, que auxilia na digestão; }\end{array}$ & $\begin{array}{l}\text { Mil em Rama } \\
\text { Funcho }\end{array}$ \\
\hline $\begin{array}{l}\text { 15h00min } \\
17 \mathrm{~h} 00 \mathrm{~min}\end{array}$ & Bexiga & $\begin{array}{c}\text { é a vez da bexiga, recebe e armazena a } \\
\text { urina }\end{array}$ & $\begin{array}{l}\text { Cavalinha } \\
\text { Malva }\end{array}$ \\
\hline $\begin{array}{l}\text { 17h00min } \\
19 \mathrm{~h} 00 \mathrm{~min}\end{array}$ & Rins & $\begin{array}{l}\text { os rins trabalham com os líquidos tomados } \\
\text { no período anterior; }\end{array}$ & $\begin{array}{c}\text { Carqueja } \\
\text { Quebra Pedra }\end{array}$ \\
\hline $\begin{array}{l}\text { 19h00min } \\
21 \mathrm{~h} 00 \mathrm{~min}\end{array}$ & $\begin{array}{l}\text { circulação } \\
\text { e aparelho } \\
\text { reprodutor }\end{array}$ & horário da circulação e aparelho reprodutor; & $\begin{array}{l}\text { Arnica } \\
\text { Alcanfor }\end{array}$ \\
\hline $\begin{array}{l}21 \mathrm{~h} 00 \mathrm{~min} \\
23 \mathrm{~h} 00 \mathrm{~min}\end{array}$ & $\begin{array}{l}\text { (sistema } \\
\text { digestivo/ } \\
\text { respiratório/ } \\
\text { excretor) }\end{array}$ & $\begin{array}{l}\text { horário do Triplo Aquecedor (sistema diges- } \\
\text { tivo/ respiratório/ excretor) período em que } \\
\text { o sistema de limpeza do corpo funcionará, } \\
\text { acionado pelo aparelho digestivo, o } \\
\text { aparelho respiratório e o aparelho excretor; }\end{array}$ & $\begin{array}{l}\text { Sálvia } \\
\text { Orégano }\end{array}$ \\
\hline $\begin{array}{l}\text { 23h00min } \\
01 \mathrm{~h} 00 \mathrm{~min}\end{array}$ & Vesícula & $\begin{array}{l}\text { horário da vesícula biliar, acumula, } \\
\text { armazena e concentra a bile. }\end{array}$ & $\begin{array}{l}\text { Bardana } \\
\text { Dente de } \\
\text { Leão }\end{array}$ \\
\hline $\begin{array}{l}\text { 01h00min } \\
\text { 03h00min }\end{array}$ & Fígado & $\begin{array}{l}\text { horário do grande chefe, o maestro e } \\
\text { comandante do processo de formação do } \\
\text { corpo: o fígado. Produz a bile e elimina } \\
\text { substâncias nocivas }\end{array}$ & $\begin{array}{l}\text { Alcachofra } \\
\text { Cardo } \\
\text { Mariano }\end{array}$ \\
\hline
\end{tabular}

Fonte: Adaptado da EMATER 2004

No Brasil, aproximadamente trezentas plantas medicinais são utilizadas de maneira terapêutica pela população. Muitas desconhecidas ou com pouca ênfase por parte dos profissionais de saúde, as plantas medicinais são utilizadas por grande parte da população, independente da classe social. (EMBRAPA, 2008). 


\section{METODOLOGIA}

A pesquisa caracteriza-se como uma pesquisa do tipo intervenção pedagógica de cunho qualitativo e de natureza aplicada. A pesquisa do tipo intervenção pedagógica caracteriza-se na qual é realizado o planejamento e aplicação de intervenções que visam à melhoria no processo de ensino e de aprendizagem (DAMIANI et. al, 2013). A pesquisa tem por intuito verificar as potencialidades da utilização do relógio medicinal do corpo humano como instrumento de ensino de matemática em uma escola do campo.

Pesquisas do tipo intervenção pedagógica são organizadas em dois métodos: método de intervenção (método de ensino) e o método de avaliação da intervenção (DAMIANI et. al, 2013). O método de intervenção é detalhado abaixo e pode ser entendido como a prática em sala de aula.

O projeto organizou-se através da metodologia da aprendizagem criativa, embasada na espiral da aprendizagem criativa, como explica Resnick (2020) a espiral da aprendizagem criativa é a base do pensamento criativo, sendo um ciclo: imaginar, criar, brincar, compartilhar, refletir, imaginar...

O imaginar foi feito por meio de indagações como: a) Quais sentimentos são despertados quando você lembra o chá que sua mãe ou avó faziam quando você estava doente? b) Você costuma fazer chá usando plantas medicinais? c) Você conhece um relógio medicinal do corpo humano? d) Como você imagina que ele é feito?

Após a etapa do imaginar, realizou-se uma explanação teórica sobre o assunto, na qual foram apresentados conceitos sobre o relógio medicinal do corpo humano. Então, chegou à hora de pôr a mão na massa e os alunos foram desafiados a criar um relógio medicinal do corpo humano na escola. Ao criar o brincar foi realizado na exploração dos materiais e desenvolvimento da atividade.

O compartilhar se fez presente com mais ênfase, após o relógio estar pronto, etapa na qual os alunos explicaram como o relógio funcionava para os alunos 
SABERES E EXPERIÊNCIAS DE PRATICAS PEDAGÓGICAS NO CONTEXTO EDUCACIONAL

de outras turmas, funcionários e comunidade geral, ressaltando a indicação da planta medicinal conforme o horário e órgão.

Salienta-se ainda a presença de alguns conceitos chaves da aprendizagem criativa no projeto: 4 P's da aprendizagem criativa e conceitos como teto alto, piso baixo, paredes amplas. Os 4 P's da Aprendizagem criativa são: projetos, paixão, pares e pensar brincando (RESNICK, 2020).

Ressalta-se que a Rede Brasileira de Aprendizagem Criativa no ano de 2021, acrescentou mais um $P$, aos quatro Ps , o quinto $P$ é o do propósito, que trata do contexto social, cultural e ambiental no qual o aprendizado está situado.

A atividade possui piso baixo (etapa do imaginar) a parte do envolvimento no projeto uma atividade que qualquer pessoa tenha facilidade de desenvolver, paredes amplas permite a exploração de diferentes materiais e atividades do mais simples ao mais complexo (etapa criar) e por fim, teto alto, complexidade da atividade vai aumentando, nesse caso, um direcionamento que poderia ser dado para o projeto seria o desenvolvimento do sistema de rega automática do relógio, atividade que já está sendo planejada e pensada para ser executada posteriormente.

A avaliação do método de intervenção se deu por meio de um questionário aplicado no fim do projeto e pela observação dos estudantes durante a atividade.

\section{RESULTADOS E DISCUSSÃO}

A conversa inicial com os alunos demonstrou a grande utilização de plantas medicinais para o tratamento e alívio de dores sobre várias doenças, a preparação das plantas medicinais se dá em sua grande maioria através de chás e percebe-se que o conhecimento é passado de geração em geração ao longo dos anos. As lembranças dos chás das mães e avós trouxeram sentimentos de saudade, nostalgia, cuidados e amor. Muitos estudantes relataram que ainda utilizam chás quando estão doentes, substituindo medicamentos comprados, visto que as plantas medicinais são produtos naturais. 
SABERES E EXPERIÊNCIAS DE PRATTICAS PEDAGÓGICAS NO CONTEXTO EDUCACIONAL

Ao imaginar como seria o relógio medicinal do corpo humano, diversas ideias surgiram, mas nenhum aluno já havia visto um relógio medicinal do corpo humano pessoalmente, os quais ficaram entusiasmados em construir o relógio na escola.

Durante a construção do relógio diversos questionamentos foram surgindo. A primeira pergunta foi a seguinte: Qual a diferença de um círculo e uma circunferência? Rapidamente os alunos, apontaram que círculo correspondia ao relógio todo, enquanto que a circunferência tratava-se apenas do contorno do relógio.

De acordo com Rufino e Silva (2020) os alunos do ensino fundamental apresentam dificuldades para compreender os conceitos pelo não reconhecimento de uma circunferência ou de um círculo, para tanto ressalta que a simples formalização dos procedimentos de ensinar matemática com fórmulas e cálculo não sustenta a abstração do conceito, por outra via considera necessário que haja raciocínio matemático que lhe dê base em aspectos sensoriais de abstração, fundamentado no processo cognitivo ausubeliano, que desenvolve conceitos abstratos por meio da experiência do indivíduo.

Entendido a diferença entre círculo e circunferência, partiu-se para o seguinte problema: Como fazer uma circunferência do tamanho necessário para construir o relógio? Está questão teve alguns apontamentos:

Aluno A: podemos desenhar a circunferência com uma enxada.

Aluno B: podemos fazer um compasso utilizando um cabo de vassoura e um pedaço de barbante.

Aluno C: não sei professora, se fosse menor poderíamos usar um compasso de verdade.

Após discutir os apontamentos com os alunos, percebeu-se que ao desenhar o relógio apenas com a enxada a circunferência ficaria torta, pois um aluno desenhou em um uma folha de papel a circunferência com uma caneta simulando a problemática inicial e percebeu que ficaria torto. Ao utilizar o compasso na folha de papel verificou-se que a circunferência ficaria melhor definida e assim 
SABERES E EXPERIÊNCIAS DE PRATICAS PEDAGÓGICAS NO CONTEXTO EDUCACIONAL

decidiu-se executar a solução apontada pelo aluno B e verificar se esta funcionaria corretamente.

Ressalta-se a criatividade do aluno ao criar o compasso maior, pode-se perceber a espiral da aprendizagem criativa acontecendo neste momento, pois os alunos tiveram que imaginar como fazer a primeira solução, desenhar com a enxada foi experimentada, compartilhada e ocorreu uma reflexão de que esta não era a mais viável, então imaginaram novamente, criaram a solução de fazer um compasso maior, experimentaram, compartilharam e refletiram a ideia que esta era a melhor opção.

Amaral e Carreira (2017) reconhecem que a criatividade pode ser muito complexa, podendo variar de uma pessoa para outra, isto quer dizer que depende do que se entende sobre produtos criativos, devido a ampla concepção de criatividade, porém não há um conceito exato que define a criatividade. No entanto, os indivíduos são criativos, mesmo que uns sejam mais que os outros, os autores ainda destacam que para ser criativo é preciso ter conhecimento suficiente sobre determinado campo.

Com a circunferência desenhada, apresentaram-se soluções para a problemática: Qual a melhor maneira de construir a circunferência e quais os materiais necessários? A turma unanimemente definiu que a melhor maneira era fazer o círculo dividido em quatro partes com plantas medicinais e um corredor semeIhante a uma cruz no canteiro. Os materiais apontados foram: bambu, garrafa pet e pavers de cimento. A melhor opção escolhida foi a última citada, pois já havia a disponibilidade destes materiais na escola.

Decidido a opção de quatro divisões com plantas no canteiro, os alunos chegaram à conclusão que cada canteiro deveria ser dividido em três partes, pois ao efetuar a multiplicação 3x4 obtinham o total de 12 partes necessárias, visto que o dia possui 24 horas e a cada duas horas um órgão tem maior assimilação do chá ingerido. 
SABERES E EXPERIÊNCIAS DE PRATICAS PEDAGÓGICAS NO CONTEXTO EDUCACIONAL

Questionados de como medir uma porção em três partes iguais, dois objetos foram sugeridos para realizar a respectiva medição: trena e transferidor. Dúvidas surgiram de qual seria melhor e de onde posicionar o transferidor. Experimentaram medir com a trena e não tiveram muita confiança nos resultados. Ao medir com o transferidor, foi explicado que a projeção do ângulo do relógio era semelhante a medir um ângulo no caderno, logo a marca do transferidor deve ser posicionada na origem do ângulo. O seguinte questionamento surgiu:

Professora: Mas, afinal, o que é ângulo?

Aluno C: Uma medida.

Professora: Mas medida de quê?

Aluno C: Desse ponto até aquele.

Professora: Isso, no contexto aplicado do relógio visualizamos um ângulo onde você disse, pode expressar matematicamente, isto, pelo conceito de que ângulo é a medida da abertura entre duas semirretas que possuem a mesma origem.

Após o entendimento dos conceitos os alunos efetuaram as medições e demarcaram os traços com giz, posteriormente escavaram com uma enxada e a seguir colocaram os pavers. Para fixar os pavers, era necessário cimento, surgiu aí outro questionamento:

Professora: Como fazer concreto?

Aluno A: Eu sei que usa areia, cimento e água, mas não sei a quantidade de cada um.

Aluno B: Eu acho que temos que colocar uma pá de cimento, três de areia e completar com água até dar o ponto.

Os alunos resolveram experimentar a dica do colega, tudo em ordem até perceberem que o concreto não estava grudando, logo, um dos alunos, apontou que a massa feita tinha pouco cimento, então na próxima vez seria necessário colocar 2 (duas) pás de areia, 1 (uma) de cimento e água até dar o ponto. A segunda receita ficou melhor e os alunos consertaram os blocos que estavam descolando. 
SABERES E EXPERIÊNCIAS DE PRÁTICAS PEDAGÓGICAS NO CONTEXTO EDUCACIONAL

Ressalta-se a presença de conceitos do cotidiano dos alunos, como no caso do cimento, no qual o aluno que era filho do pedreiro trouxe sua vivência adquirida através dos ensinamentos de seu pai, refletiu e apontou a solução para o problema do concreto não ter grudado. Assim, vê-se que o conhecimento inicial do aluno é agregado a novos conhecimentos científicos. Com os pavers cimentados nos locais e a parte inicial do cimento feita, os alunos estudaram mais alguns conceitos matemáticos presentes no relógio.

A experiência age como o papel formador, entrelaça o que é chamado de saberes com o conhecimento acadêmico, esta articulação desperta a sensação de valorização, e também, que a experiência para Marx é produzida pela história humana por meio da produção material (Schwartz, 2010).

Qual a constante que pode ser encontrada na circunferência de um prato, na circunferência de um copo e na circunferência do relógio? Essa questão foi respondida de maneira prática. Para começar, mediram a circunferência e o diâmetro dos seguintes objetos: copo, prato, tampa da panela, fundo do prato e do relógio medicinal do corpo humano e anotaram os resultados, relatados na Tabela 2.

Tabela 1 - Tabela de medição de quociente

\begin{tabular}{|c|c|c|c|}
\hline \multicolumn{4}{|c|}{$\begin{array}{l}\text { Medição para encontrar o quociente entre } \\
\text { o comprimento da circunferência e seu diâmetro. }\end{array}$} \\
\hline Objeto & $\begin{array}{l}\text { Circunferência } \\
\qquad(\mathrm{cm})\end{array}$ & Diâmetro(cm) & $\begin{array}{c}\text { Valor obtido através da } \\
\text { divisão da circunferência } \\
\text { pelo diâmetro(cm) }\end{array}$ \\
\hline Prato & 75 & 22,4 & 3,28 \\
\hline Copo & 23 & 7 & 3,28 \\
\hline Tampa da panela & 87 & 27,5 & 3,16 \\
\hline Fundo do prato & 43 & 14,5 & 2,98 \\
\hline $\begin{array}{l}\text { Relógio medicinal do } \\
\text { corpo humano }\end{array}$ & 125 & 38 & 3,28 \\
\hline
\end{tabular}

Fonte: Autoria própria, 2020. 
SABERES E EXPERIÊNCIAS DE PRATICAS PEDAGÓGICAS NO CONTEXTO EDUCACIONAL

Explicou-se aos alunos, que o valor obtido na divisão da circunferência pelo diâmetro era chamado de $\mathrm{Pi}(\pi)$ e valia cerca de 3,14 . Ao visualizar na prática notou-se que os valores obtidos na última coluna do quadro eram aproximados a 3,14. Após discutir os conceitos ligados ao Pi, começou-se a trabalhar com frações. Considerando apenas o ponteiro dos minutos de um relógio manual, como podemos representar uma hora inteira? Os alunos rapidamente apontaram que seria o relógio todo, logo, a partir disso, esclareceu-se que o relógio todo correspondia a um inteiro.

Como podemos representar a metade (um meio) do relógio considerando o ponteiro dos minutos? Assim em seguida, apontaram que seria o caminho percorrido pelo ponteiro do relógio do 12 ao 6 e do 6 ao 12. Assim pode-se entender que o inteiro foi dividido em duas partes, e cada parte correspondia a $1 / 2$ (metade) do relógio.

Posteriormente, questionou-se os alunos sobre a fração que correspondia ao relógio, quando se dividia o relógio todo em partes de quinze minutos, assim os alunos esclareceram que ao fazer a divisão, cada parte com 15 minutos correspondia a $1 / 4$ do relógio. Partindo desse pressuposto, questionou-se acerca do que era fração? "Aluno A: um número inteiro dividido em partes iguais, Aluno B: um inteiro dividido em partes iguais". Dessa forma, possibilitou a discussão acerca dos apontamentos e explicou-se que a definição de fração correspondia a afirmação dada pelo aluno $B$.

Ao efetuar o plantio do canteiro, trabalhou-se com os conceitos de porcentagem e operações básicas. Além de conteúdo como solo, adubação e plantas medicinais. Após a construção do relógio medicinal do corpo humano os estudantes explicaram o projeto para alunos, funcionários e pessoas da comunidade que estavam presentes, ressaltando que o projeto não se limitava a escola e que o pessoal da comunidade poderia colher as plantas medicinais do relógio e sempre que se sentissem à vontade as pessoas poderiam cuidar do canteiro.

Nesse caminho percorrido pela humanidade, o uso das plantas medicinais tornou-se popular e entendido como um patrimônio cultural imaterial. Patrimônio 
SABERES E EXPERIÊNCIAS DE PRATICAS PEDAGÓGICAS NO CONTEXTO EDUCACIONAL

cultural imaterial são todas as manifestações populares que decorrem das tradições e costumes que acontecem desde muito tempo em determinadas regiões ou comunidades, e por serem imateriais ou intangíveis, distinguem-se dos monumentos históricos que são bens materiais (BLADIN, ACOSTA, 2018).

Após a conversa, um ponto chamou a atenção: quem iria molhar o relógio medicinal do corpo humano? Assim sendo, como poucas pessoas podiam fazer a rega, uma solução apontada foi a criação de um sistema de rega automatizado, que é um trabalho que será desenvolvido posteriormente, sendo o teto alto do projeto.

Percebe-se que os alunos conseguiram entender os conteúdos aprendidos durante o projeto, sendo assim o relógio do corpo humano como uma proposta viável para o ensino de matemática, de maneira criativa nas escolas do campo. Diagnosticou-se que diversas vezes a espiral da aprendizagem criativa aconteceu assim através de erros e acertos os alunos conseguiram chegar à solução final.

No caso dessa atividade:

- P do projeto se fez presente, visto que os alunos desenvolveram um projeto, percorrendo a espiral da aprendizagem criativa e desenvolvendo seu pensamento criativo;

- P da paixão está no envolvimento dos alunos na construção do relógio;

- P dos pares é visto quando os alunos compartilham e refletem para resolver os problemas que estão presentes no projeto;

- P do pensar brincando no qual os alunos exploram os materiais e brincam na realização da atividade.

$\mathrm{O}$ quinto $\mathrm{P}$ está presente no relógio, visto que o relógio resgata a cultura do consumo de plantas medicinais, tendo uma relação com o contexto ambiental com a preservação das plantas medicinais e minimiza um problema no contexto 
social que o do consumo exagerado de medicamentos industrializados, que muitas vezes, podem ser substituídos por plantas medicinais.

\section{CONCLUSÃO}

A utilização de medicamentos naturais tem se demonstrado eficiente desde os mais longínquos dos tempos, muitos estudos e pesquisas realizadas nesse sentido demonstram que existem comprovação científica da eficácia das plantas como tratamento e alívio de sintomas que afetam o corpo.

Percebemos no decorrer do projeto maior interação dos alunos e motivação frente aos conhecimentos adquiridos. A percepção dos conteúdos e a relevância do resgate do convívio familiar trouxe muito conteúdo enriquecendo as aulas em todos os sentidos. Os resultados atingidos ultrapassaram o esperado inicialmente, houve engajamento, dedicação, colaboração, espírito de equipe e muita disposição desde o início das atividades propostas, implementação e execução. A utilização de atividade criativa traz benefícios diversos para os alunos como foco e estímulo a criatividade, torna ainda protagonistas em seu processo de aprendizagem.

A escola deve ser um ambiente propício para estimular e desenvolver a criatividade, em síntese esse aprendizado fora da caixa aproxima a educação ao mundo real, utilizando técnicas que favoreçam a aprendizagem auxiliando no desenvolvimento de habilidades e competências necessárias para o mundo e a vida em sociedade. A educação criativa é uma metodologia na qual permite que as escolas do campo se aproximem do mundo real e das habilidades requeridas por esse cenário.

Espera-se que os resultados aqui relatados possam alcançar a toda comunidade e interessados, com o objetivo que essa prática possa integrar mais elementos trazendo benefícios que ultrapassam a sala de aula, e alcance a vida do aluno como ser social. A relação matemática e ensino criativo têm muitos pontos a ser considerados, enquanto trabalha em sua criatividade de pensamento e raciocínio lógico, o aluno também acaba trabalhando na construção de sua auto- 
confiança e autoestima, na capacidade de desenvolver pensamento convergente e divergente, no estímulo à colaboração e ao desenvolvimento da resiliência, na capacidade de lidar com problemas e de propor soluções para eles, criando pensamento crítico e reflexivo, entre outras tão importantes.

\section{REFERENCIAS}

AMARAL, N. e CARREIRA, S.. A Criatividade Matemática nas Respostas de Alunos Participantes de uma Competição de Resolução de Problemas. Bolema: Boletim de Educação Matemática [online]. 2017, v. 31, n. 59 [Acessado 16 Outubro 2021] , pp. 880-906. Disponível em: <https://doi.org/10.1590/1980-4415v31n59a02>. Acesso em: 13 out. 2021.

ARAÚJO, I. X.; SILVA, S. B. Educação do campo e a formação sociopolítica do educador. João Pessoa: Editora Universitária da UFPB, 2011.

AVILA,R. M. F. de, Programa de Extensão das Plantas Medicinais: promovendo educação e saúde em Bento Gonçalves, Revista da Pró-Reitoria de Extensão do IFRS, $n^{\circ} 9,2021$.

BALDIN, N.; ACOSTA, P. M. R. Representações sociais do uso popular de plantas medicinais:experiência em uma comunidade rural, Revista de Educação Pública, [S. I.], v. 27, n. 64, p. 159-178, 2017. Disponível em: https://periodicoscientificos.ufmt.br/ojs/index.php/educacaopublica/article/view/3267. Acesso em: 14 out. 2021.

BRASIL, Lei de Diretrizes e Bases da Educação Nacional (LDB). Lei n 9.394, de 20 de dezembro de 1996. Estabelece as Diretrizes e Bases da Educação Nacional. MEC: Brasília, 1996. Disponível em: . Acesso em: 17 de outubro de 2021.

BRASIL, Ministério de Educação e Cultura. Parâmetros Curriculares Nacionais para o Ensino Fundamental Matemática - 5a a 8 ${ }^{\mathrm{a}}$ série. Brasília, SEF, 1999.

CALDART, R. S.. Educação do Campo: notas para uma análise de percurso. In: II Encontro Nacional de pesquisa sobre Educação do Campo. Brasília, 2008. Disponível em: < http://www.scielo.br/pdf/tes/v7n1/03.pdf>. Acesso em: 17 de outubro de 2021.

D’AMBROSIO, U. Transdisciplinaridade. São Paulo: Palas Athena, 1997. 
D'AMBRÓSIO, U. Etnomatemática. Elo entre as tradições e a modernidade. 2a Edição. Belo Horizonte: Autêntica, 2002. 110 p. (Coleção Tendências em Educação Matemática).

DAMIANI, M. F. et al, Discutindo pesquisas do tipo intervenção pedagógica. Revista Cadernos da Educação, n.45, 2013.

EMBRAPA, Plantas medicinais do cultivo, manipulação e uso à recomendação popular, Pará, 2008.

EMATER, As plantas medicinais do corpo humano, Rio Grande do Sul, 2004.

FREIRE, P.. Uma Educação para a Liberdade. 4ª edição, Porto, Textos Marginais, 1974

KRASILCHIK, M. Prática de ensino de biologia. 4. ed. São Paulo, SP: EDUSP, 2008. 197 p. ISBN 9788531407772.

PARANÁ. Diretrizes Curriculares da Educação do Campo. SEED: Curitiba, 2006. Disponível em: . Acesso em: 17 de outubro de 2021.

RESNICK, M. Jardim de infância para a vida toda por uma aprendizagem criativa, mão na massa e relevante para todos. Edição Kindle, Porto Alegre,Editora Penso, 2020.

SACHS, L. Currículo de matemática na educação do campo: panoramas e zonns. Zetetiké Revista de Educação Matemática, v.26, n.2, 2018.

SADOVSKY, P. O ensino de matemática hoje. Enfoques, sentidos e desafios. 1.ed. São Paulo: Ática, 2007.

SCHWARTZ, Y. A experiência é formadora? Educação e Realidade. v. 35, n. 1. 2010. Disponível em: https://www.redalyc.org/pdf/3172/317227076004.pdf. Acesso em: 17 de outubro de 2021.

SILVA RUFINO, M. A.; SILVA, J. R. Um estudo acerca da potencialidade significativa de um material de ensino sobre circunferência e círculo. REMATEC, v. 15, n. 35, p. 100-121, 4 dez. 2020. Disponível em: http://rematec.net.br/index.php/ rematec/article/view/288. Acesso em: 17 de outubro de $2021 .$.

VELLOSO, C.C. WERMANN, A. F.FUSIGER,T.B. Horto medicinal relógio do corpo humano, EMATER, Rio Grande do Sul, 2005. 


\section{SOBRE OS ORGANIZADORES}

\section{FABIANO CUSTÓDIO DE OLIVEIRA}

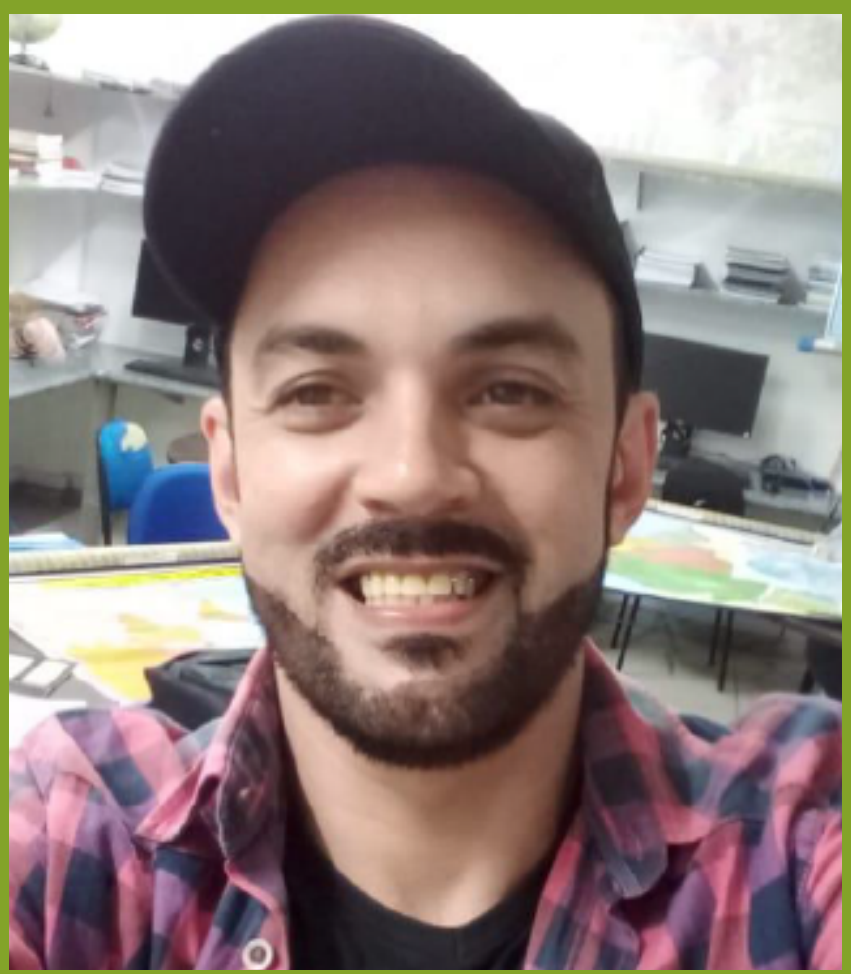

Fabiano Custódio de Oliveira é doutor em Planejamento Urbano e Regional, pela Universidade Federal do Rio de Janeiro (2017). Mestre em Geografia pela Universidade Federal da Paraíba (2007). Licenciado em Geografia pela Universidade Estadual da Paraíba (2004). Licenciado em Pedagogia pela Faculdade IBRA de Brasília (2021). Atualmente é professor da Universidade Federal de Campina Grande - UFCG e lotado no Centro de Desenvolvimento Sustentável do Semiárido - CDSA - Sumé/PB. É coordenador do Laboratório de Ensino de Geografia e Educação do Campo (LEGECAMPO). Membro do Núcleo de Pesquisa em Educação do Campo, Formação de Professores/as e Práticas Pedagógicas (NUPEFORP). É professor de Geografia da Licenciatura Interdisciplinar em Educação do Campo (UFCG) na Area das Ciências Humanas e Sociais. Também ministra disciplinas no Curso Superior Tecnólogo em Agroecologia (UFCG). É professor do Mestrado Profissional de Sociologia em Rede Nacional (PROFSOCIO/UFCG) e do Mestrado Profissional em Ensino de Geografia (PROFGEO/UFCG).Tem experiência na área de Geografia, atuando nas seguintes linhas: Ensino de Geografia e Educação do Campo; Educação Contextualizada; Produção e Experimentação de Recursos Didáticos e Estudo da Dinâmica e Produção de Territoriais e Educação Ambiental. 


\section{DENISE XAVIER TORRES}

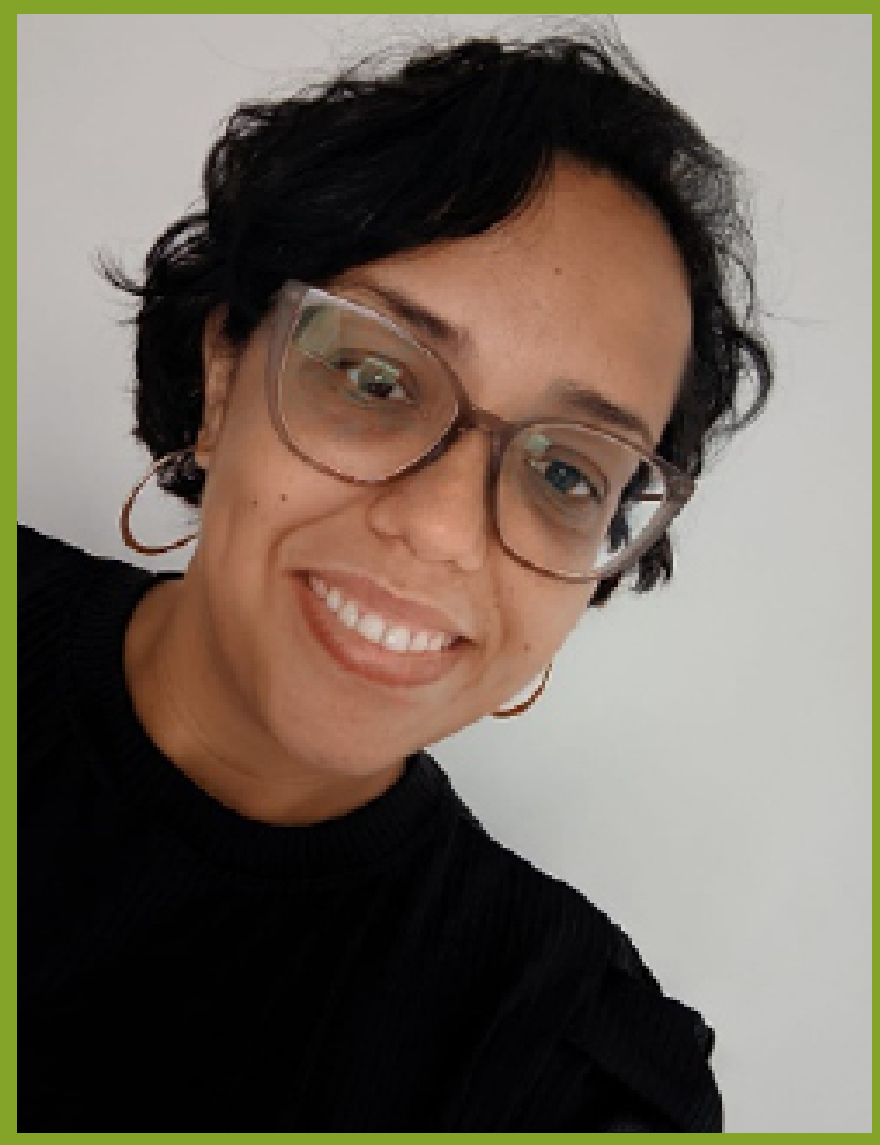

Denise Xavier Torres é doutora em Educação pela Universidade Federal de Pernambuco (2018). Mestre em Educação pela Universidade Federal de Pernambuco (2013). Licenciada em Pedagogia pela Universidade Federal de Pernambuco (2010). Atualmente é professora Adjunta da Universidade Federal de Campina Grande - UFCG e lotada no Centro de Desenvolvimento Sustentável do Semiárido - CDSA - Sumé/PB. Membro do Núcleo de Pesquisa em Educação do Campo, Formação de Professores/as e Práticas Pedagógicas (NUPEFORP). É professora do Mestrado em Educação da Universidade Federal de Campina Grande. 


\section{MARIA DA CONCEIÇÅO GOMES DE MIRANDA}

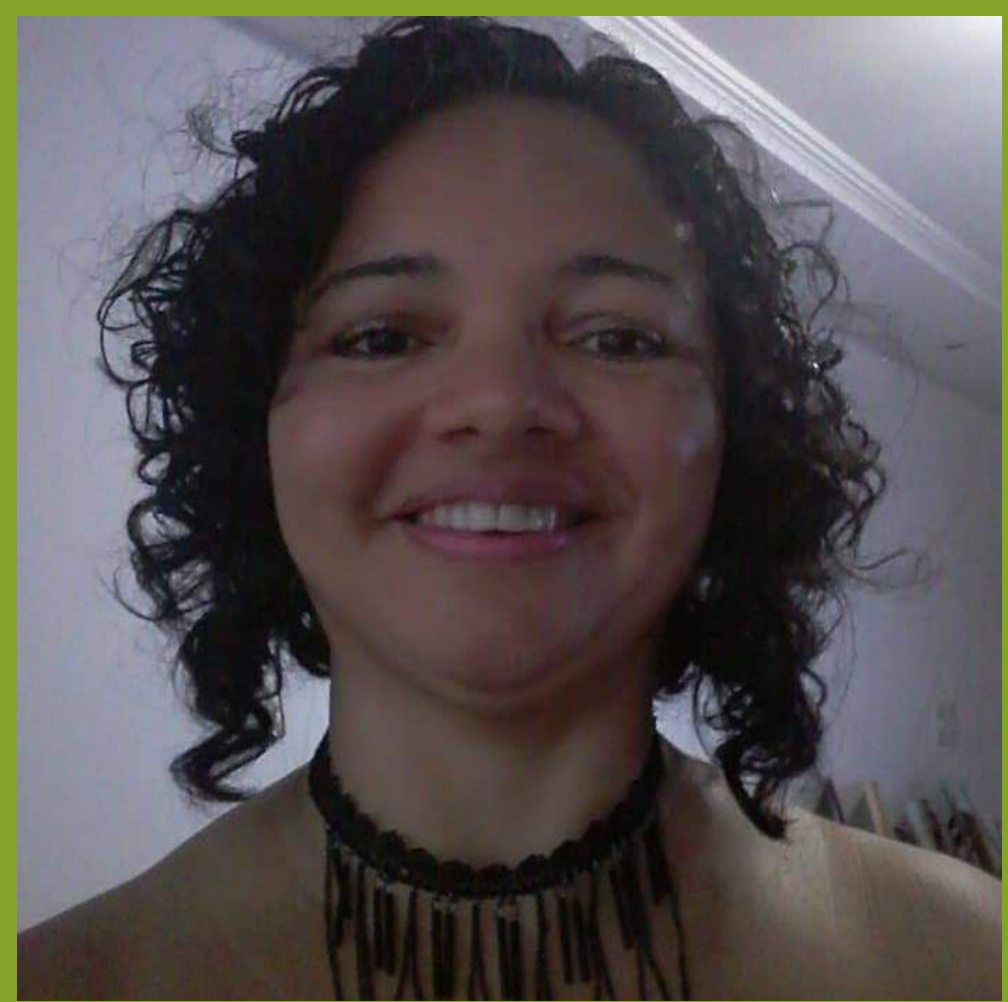

Maria da Conceição Gomes de Miranda - Doutora em Educação, professora da Universidade Federal da Paraíba. É Professora Associada I e compõe o quadro permanentedo Mestrado de Sociologia em Rede Nacional - PROFSOCIO, na modalidade Profissional, associada UFCG/CDSA, na Unidade Acadêmica de Ciências Sociais, daUniversidade Federal de Campina Grande. Atua ainda como Assessora de Extensão do Centro de Educação da UFPB desde fevereiro de 2019. 


\section{SOBRE AS AUTORAS E OS AUTORES}

\section{Aldo Gonçalves de Oliveira}

Professor Adjunto na Universidade Federal de Campina Grande - UFCG, Centro de Formação de Professores - CFP, Unidade Acadêmica de Geografia - UNAGEO. Coordenador de Projeto de Pesquisa 2021. Doutor em Geografia. E-mail: aldojua@yahoo.com.br

\section{Alisson Clauber Mendes de Alencar}

Estudante do Curso de Licenciatura Interdisciplinar em Educação do Campo - UFCG/ CDSA. Vinculado ao Núcleo de Estudo, Pesquisas e Práticas em Formação de Professores - NUPEFORP. E-mail: alissonclauber@gmai.com

\section{Antonio Carlos Soares de Mota}

Licenciado em Educação do Campo - Área de Ciências Humanas e Sociais da Universidade Federal de Campina Grande. Mestrando pelo Programa Profissional em Rede Nacional de Gestão e Regulação de Recursos Hídricos - PROFÁGUA/UFCG. Vinculado ao Núcleo de Estudos e Pesquisas em Educação do Campo, Formação de Professores/as e Práticas Pedagógicas - NUPEFORP/CDSA/UFCG. e pesquisador do LEGECAMPO. E-mail: antoniocarlos49ers@gmail.com

\section{Cícera Cecília Esmeraldo Alves}

Professora Adjunta na UFCG, CFP, UNAGEO. Coordenadora de Projeto de Extensão PROBEX UFCG 2019 e de Pesquisa 2021. Doutora em Geografia.

E-mail: ceciliaesmeraldo@gmail.com.

\section{Denise Xavier Torres}

Professora do curso de Licenciatura Interdisciplinar em Educação do Campo da Universidade Federal de Campina Grande - Centro de Desenvolvimento Sustentável do Semiárido - UFCG/CDSA. Vinculado ao Núcleo de Estudo, Pesquisas e Práticas em Formação de Professores - NUPEFORP. E-mail: denise.xavier@professor.ufcg.edu.br

\section{Danilo de Souza Farias}

Licenciado em Educação do Campo - Área das Ciências Humanas e Sociais - Universidade Federal de Campina Grande; Mestrando em Educação - PPGED/UFCG; Membro do NUPEFORP e do LEGECAMPO/UFCG. E-mail: danilofariasufcg@gmail.com. 


\section{Eloiza Aparecida Silva Ávila de Matos}

Doutora em Educação pela Universidade Metodista de Piracicaba- UNIMEP, Professora do Programa de Pós- Graduação em Ensino de Ciência e Tecnologia- UTFPR.

E-mail: elomatos@utfpr.edu.br

\section{Fábio Fernandes Villela}

Sociólogo, Departamento de Educação, Universidade Estadual Paulista (Unesp), Instituto de Biociências Letras e Ciências Exatas, São José do Rio Preto.

E-mail: fabio.villela@unesp.br

\section{Ivanalda Dantas Nóbrega Di Lorenzo}

Professora Adjunta na Universidade Federal de Campina Grande - UFCG, Centro de Formação de Professores - CFP, Unidade Acadêmica de Geografia - UNAGEO. Coordenadora de Projeto de Extensão PROBEX UFCG 2019. Coordenador de Projeto de Pesquisa 'Geografias e Histórias do Lugar e dos Sujeitos Assentados da Reforma Agrária: Interdisciplinaridade e Educação do Campo na Formação Dodiscente na EEEF Renê Alves Ramalho, Sousa - PB' - 2019-2021. Doutora em Educação.

E-mail: ivanaldadantas@gmail.com.

\section{José Fábio Vieira Gomes}

Graduado em Pedagogia - UFPB, Especialista em Educação do Campo - UFPB. E-mail: fabiogomes3333@gmail.com.

\section{José Diones Nunes dos Santos}

Professor da Educação Básica e Pesquisador. Mestre em Sociologia pela UFCG/CDSA. E-mail: dhionesdocongo@gmail.com

\section{Luciélio Marinho da Costa}

Doutor em Educação pela Universidade Federal da Paraíba - UFPB. Professor do Departamento de Fundamentação da Educação do Centro de Educação da UFPB.

\section{Laurenice Gomes Andrade}

Mestranda em Educação PPGEd/UFCG. E-mail: laurenice_23@hotmail.com

\section{Marcos Vinicius Pereira Ribeiro}

Graduando em educação do campo habilitação em ciências da natureza e matemáticaUTFPR. E-mail: vini.ribeiro8294@gmail.com

\section{Patrícia Brito Souza da Nóbrega}

Atua na área de Saneamento Ambiental, Educação Ambiental e Ensino de Química. Colaboradora no Projeto de Extensão PROBEX UFCG 2019 e de Pesquisa 2021. Mestre em Engenharia Civil e Ambiental pela Universidade Federal da Paraíba - UFPB e Graduada em Química (Lic.) pelo IFPB. E-mail: patriciadanobrega@hotmail.com. 


\section{Patrícia Gonçalves de Souza}

Doutoranda e Mestra em educação. Especialista em: Psicopedagogia Clínica e Institucional, Gestão de Escolas e Educação Infantil. Graduada em Pedagogia. Diretora Escolar da Rede Municipal de Ensino de Irecê-Ba.

\section{Rosicreide Soares Nogueira}

Licenciada em Educação do Campo - Área de Ciências Humanas e Sociais da Universidade Federal de Campina Grande. Mestranda em Educação Contemporânea pela Universidade Federal de Pernambuco. Vinculada ao Núcleo de Estudos e Pesquisas em Educação do Campo, Formação de Professores/as e Práticas Pedagógicas - NUPEFORP/CDSA/ UFCG e pesquisadora do LEGECAMPO.

E-mail: cleidesoaresn@gmail.com

\section{Soraia Stabach Ribas Ferrari dos Santos}

Mestranda no Programa de Pós-Graduação em Ensino de Ciência e Tecnologia- Universidade Tecnológica Federal do Paraná. E-mail: soraiasr@hotmail.com

\section{Tiago José Vasconcelos de Farias}

Licenciado em Educação do Campo - Área de Ciências Humanas e Sociais da Universidade Federal de Campina Grande. Mestrando em Educação pela Universidade Federal de Campina Grande - PPGED/UFCG. Vinculado ao Núcleo de Estudos e Pesquisas em Educação do Campo, Formação de Professores/as e Práticas Pedagógicas - NUPEFORP/ CDSA/UFCG e pesquisador do LEGECAMPO.E-mail: tiagojs97@gmail.com

\section{Veronice Maria Kawalek}

Mestranda no Programa de Pós-Graduação em Ensino de Ciência e Tecnologia- Universidade Tecnológica Federal do Paraná. E-mail: veronicekawalek@utfpr.edu.br. 


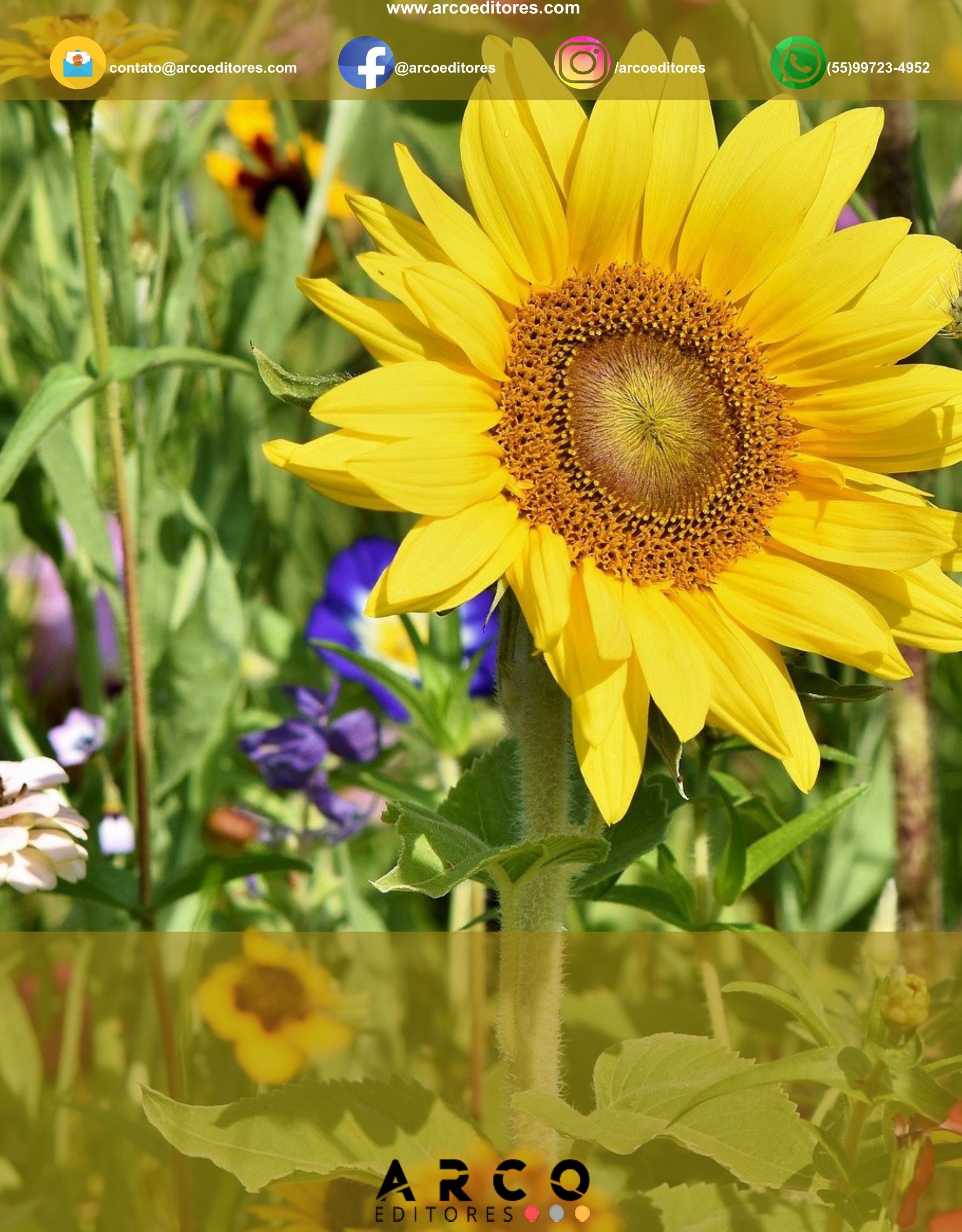

